Universidade de São Paulo

Faculdade de Medicina de Ribeirão Preto

Departamento de Genética

\title{
"Padrões diferenciais de expressão gênica no desenvolvimento das castas de Apis mellifera, com ênfase na diferenciação das operárias"
}

Tese apresentada à Faculdade de Medicina de Ribeirão Preto da Universidade de São Paulo para obtenção do título de DOUTOR em CIÊNCIAS - Área de concentração: GENÉTICA.

\author{
Aluna: Aline Carolina Aleixo Silva \\ Orientadora: Profa. Dra. Zilá Luz Paulino Simões
}




\section{Aleixo Silva, Aline Carolina}

"Padrões diferenciais de expressão gênica no desenvolvimento das castas de Apis mellifera, com ênfase na diferenciação das operárias" / Aline Carolina Aleixo Silva; orientadora Zilá Luz Paulino Simões - Ribeirão Preto, 2012.

172 p.: il.; $30 \mathrm{~cm}$

Tese de Doutorado (Área de Concentração: Genética) - Faculdade de Medicina de Ribeirão Preto da Universidade de São Paulo.

1. Apis mellifera 2. castas 3. ultraspiracle 4. cryptocephal

5. retinoid- and fatty acid-binding protein

6. esterase do hormônio juvenil 7. microRNA 
PARECER DA BANCA EXAMINADORA

Prof. Dr.

Instituição:

Parecer:

Assinatura:

Prof. Dr.

Instituição:

Parecer:

Assinatura:

Prof. Dr.

Instituição:

Parecer:

Assinatura:

Prof. Dr.

Instituição:

Parecer:

Assinatura:

Prof. Dr.

Instituição:

Parecer:

Assinatura:

Ribeirão Preto, de de 2012. 
Aos meus Pais, com quem aprendi a ser quem sou, pelo maravilhoso exemplo, e por me fazerem saber o que é o amor incondicional e o significado de "I will be there for you", DEDICO. 


\section{Agradeço imensamente:}

à Profa. Dra. Zilá Luz Paulino Simões, por todos estes anos de aprendizado, profissional e pessoal, pela imensa contribuição em minha formação, pela paciência, pelo carinho e por me proporcionar, com tanta competência, cumprir mais esta etapa.

à Profa. Dra. Christina Grozinger, por me receber em seu laboratório na Universidade do Estado da Pensilvânia (EUA), pelos ensinamentos, pela gentileza e carinho.

à Profa. Mácia Bitondi, pelo apoio e dedicação.

à Vera Figueiredo, pelo seu trabalho como técnica contribuindo para o bom andamento do laboratório como humor ácido que sempre nos divertia;

à Sara Kocher pela ajuda nos experimentos de microarrays e por fazer isto com muita dedicação.

ao Bernardo Niño, técnico do Laboratório de Ecologia Química (State College - EUA), pela imensa ajuda e paciência durante minha estadia naquele laboratório.

à Flavia Freitas pela valiosa ajuda com as análises de miRNA e RNA-Seq e por toda a paciência nas explicações e pelas sugestões,

à Karina Guidugli, Francis Nunes e Flávia Freitas pela valiosas dicas e sugestões que fizeram este trabalho melhor.

ao Roberto Barchuk pela grande contribuição em minha formação acadêmica, pelo incentivo, gentileza e bom humor de sempre e pela grande ajuda na finalização desta tese;

à Tathyana Mello, pela grande contribuição principalmente na finalização deste trabalho;

à Holly Holt pela apoio na leitura e sugestões do abstract;

à Profa. Dra. Maria Helena de Souza Goldman, pelos clones com a sequência de gfp;

a todos do $L B D A$, atuais e também aqueles que dele fizeram parte, pelo aprendizado proporcionado, pelo compartilhamento de amostras, primers, conhecimento, etc., pelo convívio diário, ótimo ambiente de trabalho e pela amizade

a toda equipe do Laboratório de Ecologia Química (State College - EUA) pela simpatia com que sempre me trataram. 
ao Prof. Dr. Ademilson Espencer Soares pelo carinho, amizade e dedicação.

aos Técnicos Apícolas do LBDA, Luiz Aguiar e Rogério Pereira, sem os quais este trabalho não seria possível.

À equipe da Secretaria do Departamento de Genética, em especial à Susie Nalon, por estar sempre disposta a ajudar.

à Pró-Reitoria de Pós-Graduação, por contribuir com minha ida aos Estados Unidos para o estágio,

à Claudinéia Costa, Flávia Freitas, Camilla Valente, Vanessa Bonatti, Omar Martinez, Michelle Prioli, Tathyana Mello, Fernanda Torres e Francis Nunes, por fazerem destes anos de Doutorado muito mais divertidos, especialmente à Lívia Moda minha companheira em todas as horas.

aos meus pais, João Bosco e Marlei, por nunca me faltarem, pelo constante apoio e incentivo.

à minha irmã Ana Gabriella que por sua admiração me faz querer ser sempre melhor, para ser um bom exemplo.

ao meu irmão Thiago e minha cunhada Priscila, por estarem sempre torcendo por mim.

à FAPESP pelo apoio financeiro, grande determinante para a realização deste trabalho e todas as atividades nele envolvidas.

ao Departamento de Genética da FMRP - USP, pela oportunidade e por contribuir com minha formação durante o Doutorado.

a todos que direta ou indiretamente contribuíram para a realização deste trabalho. 


\section{RESUMO}

Aleixo Silva, A.C. "Padrões diferenciais de expressão gênica no desenvolvimento das castas de Apis mellifera, com ênfase na diferenciação das operárias". 172 p. Tese apresentada à Faculdade de Medicina de Ribeirão Preto, Universidade de São Paulo, Ribeirão Preto, 2012.

Nas abelhas sociais Apis mellifera a determinação de castas está relacionada à nutrição diferencial durante o desenvolvimento larval. Os indivíduos são alimentados com geléia real até o terceiro estágio larval, quando aqueles que são destinados a se tornarem operárias passam a receber uma mistura de secreções glandulares, mel e pólen. O conteúdo da dieta recebida após o terceiro estágio larval ativará respostas endócrinas diferenciais que resultarão no estímulo de vias distintas de expressão gênica que culminarão no desenvolvimento de rainhas e operárias. Vários modelos de determinação de castas foram propostos envolvendo diferentes fatores que atuam sobre o desenvolvimento de cada uma, em especial o Hormônio Juvenil (HJ), as vias de sinalização por insulina/IGF e TOR (target of rapamycin) a metilação diferencial e a proteína recentemente descoberta, royalactin, que favorecem o desenvolvimento de rainhas. Para o desenvolvimento de operárias foi sugerido estímulo de outras vias de sinalização, que possivelmente envolveria a participação dos genes ultraspiracle (usp), cryptocephal (crc) e retinoid- and fatty acid-binding protein (RfaBp). Utilizando diferentes abordagens avaliamos a participação destes genes no processo que culmina no desenvolvimento das castas. Através da análise de expressão gênica em larga escala utilizando microarrays, observamos a existência de genes diferencialmente expressos em rainhas e operárias, sendo a maior que parte deles apresentou expressão preferencial em operárias. Muitos destes genes, inclusive esterase do hormônio juvenil (jhe), failed axon connections (fax), activating transcription factor-3 (atf-3), cathepsin- $D$ (cath-D) e peptidoglycan recognition protein-SC2 (pgrp-sc2), preferencialmente expressos em operárias, estão envolvidos, segundo análises de função por Gene Ontology, em processos essenciais no desenvolvimento das castas como crescimento, reprodução, apoptose, neurogênese, degradação do hormônio juvenil, entre outros. A partir destes resultados, incluímos o gene da esterase do hormônio juvenil (jhe) em nossas análises, como um possível candidato a determinante do desenvolvimento diferencial das operárias. Além disto, foi determinado o perfil de expressão de $u s p, c r c, R f a B p$ e $j h e$, durante o desenvolvimento de rainhas e operárias. Observamos que os maiores níveis de expressão de cada um são encontrados em fases posteriores ao período crítico de determinação de castas e que em geral, os maiores níveis de expressão são encontrados em operárias, especialmente $c r c, R f a B p$ e $j h e$. Para usp, os níveis são distintos em rainhas e operária apenas em pontos específicos entre o quinto estágio larval e a fase pré-pupal. Adicionalmente avaliamos a influência da diminuição, através de interferência por RNA (RNAi), dos níveis de expressão de cada um destes genes sobre os níveis dos outros genes estudados, e também sua atuação no desenvolvimento. Vimos que mesmo pequenas modificações nestes níveis inibem ou estimulam a expressão de outros genes e, em alguns casos causam alterações no desenvolvimento das abelhas. Sabendo da importância dos microRNAs (miRNAs) na regulação da expressão gênica e do desenvolvimento, avaliamos os níveis de expressão dos miRNAs preditos como reguladores de $j h e$. Os resultados obtidos mostraram que alguns deles, como let-7, miR-2796 e miR-263b, por apresentarem correlação negativa com os níveis do gene alvo, são realmente fortes candidatos a seus reguladores. Além disto, alterações nos níveis do gene alvo, mostraram a capacidade de alterar os níveis de expressão da maioria dos miRNAs preditos. Este resultado foi corroborado por sequenciamento em larga escala das amostras tratadas com dsjhe e controle, que apontou também outros possíveis reguladores de jhe, entre eles $m i R-100, m i R-306$ e mi13b. Analisando os resultados obtidos de forma conjunta podemos sugerir que o desenvolvimento de operárias está sob complexa regulação que envolve a participação dos genes aqui estudados, além de outros fatores como os miRNAs. Estes genes agem de maneira coordenada, inclusive com os miRNAs, em momentos específicos do desenvolvimento atuando sobre cascatas de expressão gênica de forma a ativar ou inibir a expressão uns dos outros e também de outros genes, o que culminará no desenvolvimento diferencial de rainhas e operárias em A. mellifera.

Palavras chave: Apis mellifera, castas, ultraspiracle, cryptocephal, retinoid-and fatty acid-binding protein, esterase do hormônio juvenil, microRNA. 


\begin{abstract}
Aleixo Silva, A.C., "Gene expression patterns governing caste determination in the honey bee (Apis mellifera) with an emphasis on worker differentiation". $172 \mathrm{p}$. Thesis presented to the Faculdade de Medicina de Ribeirão Preto, Universidade de São Paulo, Ribeirão Preto, 2012.

In Apis mellifera, a eusocial bee, caste determination during larval development is regulated by differential nutrition. All female larvae are fed royal jelly until the third larval stage, when the workerdestined ones have their diet switched to a gland secretion mix, honey and pollen, Queen-destined larvae, however, are provisioned with a rich diet throughout development. Changes in diet after the third developmental stage modulate larval endocrine responses and different nutritional regimes trigger distinct patterns of gene expression. Thus, nutritional regulation of specific signaling pathways controls development of worker and queen phenotypes. Several proposed models of this process involve caste-specific regulation of hormonal and nutritional factors and/or molecular processes including Juvenile Hormone (JH), insulin/IGF and TOR (target of rapamycin) signaling pathways, differential methylation and the newly discovered protein royalactin, which facilitates queen development. Previous research has also suggested the stimulus of other factors in signaling pathways that acts towards workers development, and they possibly involves the participation of some genes like ultraspiracle (usp), cryptocephal ( $c r c$ ), and retinoid- and fatty acid-binding protein (RfaBp). Using diverse molecular approaches, we evaluate the role of these genes in caste differentiation. We used microarrays to characterize global differences in gene expression between queen and worker larvae. Functional analysis of significantly, differentially expressed genes identified fundamental biological processes including growth, reproduction, apoptosis, neurogenesis and $\mathrm{JH}$ degradation that are involved in caste differentiation. Based on these findings, we selected several candidate genes including juvenile hormone esterase (jhe), failed axon connections (fax), activating transcription factor-3 (atf-3), cathepsin-D (cath-D), and peptidoglycan recognition protein-SC2 (pgrp-sc2) for investigation. Notably, these genes were preferentially upregulated in workers. In a separate experiment, we monitored expression of usp, $c r c, R f a B p$ and $j h e$, in queen and worker larval during stages critical to caste determination. In general, workers expressed $c r c, R f a B p$ and $j h e$ at higher levels than queens. For usp, distinct expression levels between worker- and queen-destined larvae were observed only at specific points between the $5^{\text {th }}$ larval stage and pre-pupal phase. Additionally we used RNA interference (RNAi) to monitor the impact of decreased levels of select candidate genes on larval development. We found that even small modification of gene expression levels inhibited or triggered expression of other genes, and, in some cases, caused developmental alterations. Furthermore, microRNAs (miRNAs) are also important regulators of gene expression during development and we identified miRNAs that were predicted $j$ he regulators and assessed their levels. Results determined that some miRNAs including let-7, miR-2796 e miR-263b were strong candidates for jhe regulation because they were significantly and negatively correlated with target gene expression levels. Furthermore, manipulation of target gene expression levels altered expression of most predicted miRNAs. These results were confirmed by deep sequencing of RNAi samples treated with double-stranded RNA for $j h e$ gene (dsjhe) and controls (with no treatment) which also identified other candidate $j h e$ regulators, like $m i R-100, m i R-306$ and mi-13b. Taken together, these results suggest that worker development is regulated by complex interactions that involve usp, $c r c, R f a B p$ and $j$ he in addition to other molecules, including miRNAs. These molecular participants coordinate development at specific time points by regulating activity of gene networks and each other, producing the differential development of workers and queens in A. mellifera.
\end{abstract}

Keywords: Apis mellifera, castas, ultraspiracle, cryptocephal, retinoid- and fatty acid-binding protein, esterase do hormônio juvenil, microRNA. 


\section{CONTEÚDO}

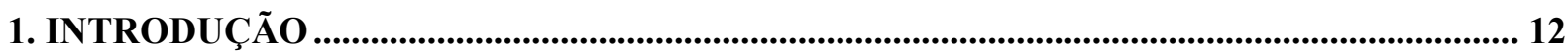

1.1 CONSIDERAÇÕES GERAIS SOBRE DETERMINAÇÃO DE CASTAS EM Apis mellifera..... 13

1.2 MODELO UNIFICADO DA DETERMINAÇÃO DE CASTAS EM Apis mellifera ...................... 15

1.3 GENES POTENCIALMENTE ENVOLVIDOS NA DETERMINAÇÃO DE OPERÁRIAS

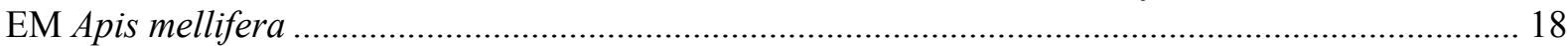

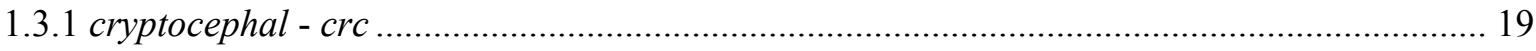

1.3.2 retinoid- and fatty acid-binding protein ou lipoforina ( $R f a B p$ ou $l p)$..................................... 20

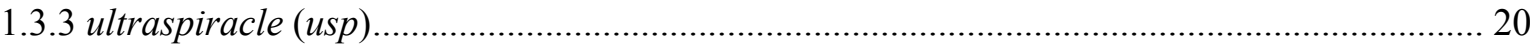

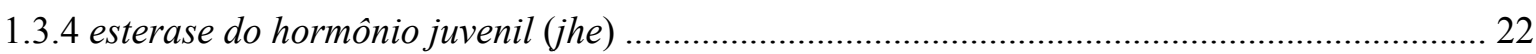

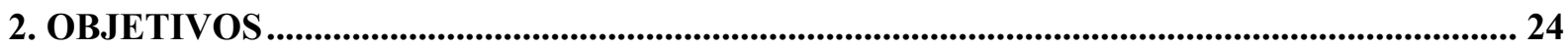

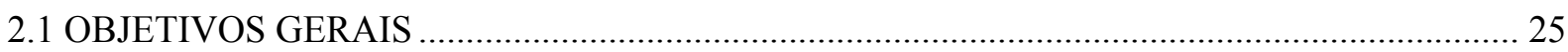

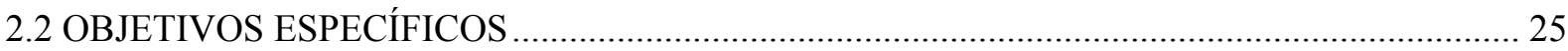

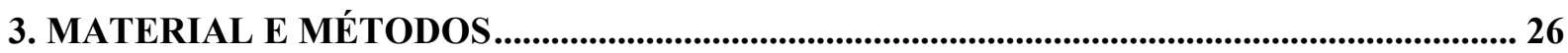

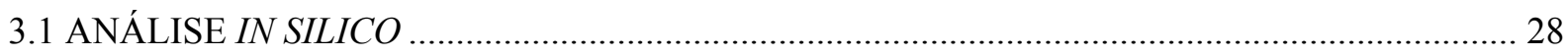

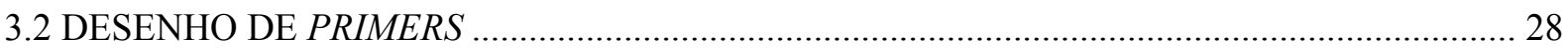

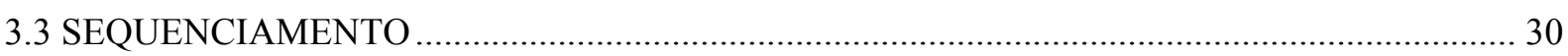

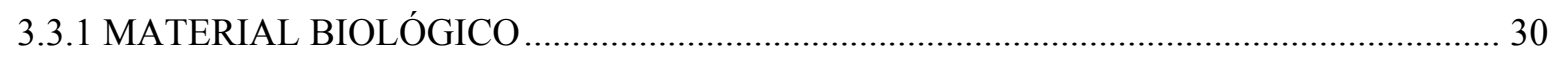

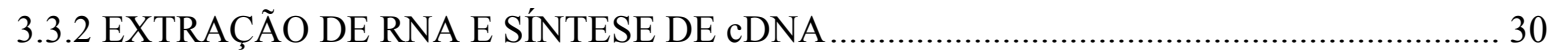

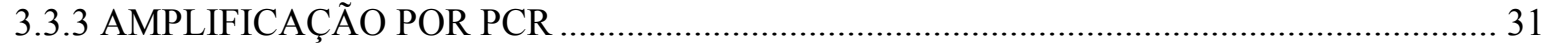

3.3.4 LIGAÇÃO DO FRAGMENTO AO VETOR DE CLONAGEM …....................................... 31

3.3.5 TRANSFORMAÇÃO BACTERIANA E MINI-PREPARAÇÕES ....................................... 32

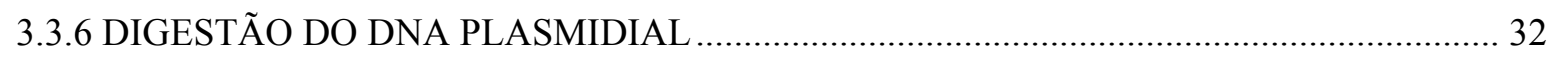

3.3.7 SEQUENCIAMENTO GÊNICO E ANÁLISE DAS SEQUÊNCIAS …............................... 32

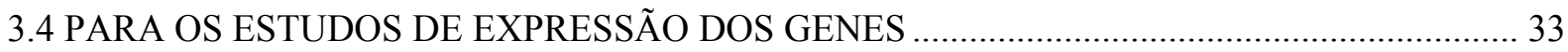

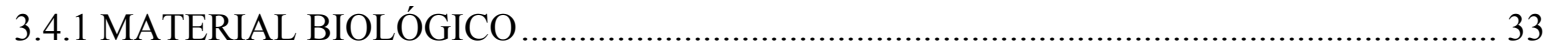

3.4.2 ANÁLISE QUANTITATIVA (qPCR) OU PCR REAL-TIME …..................................... 34

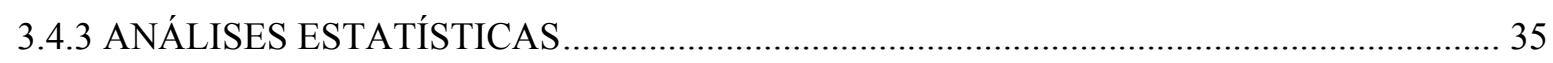

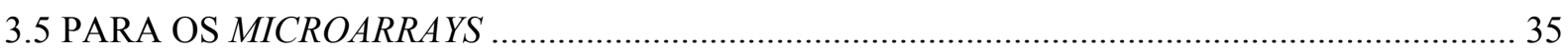

3.5.1 MATERIAL BIOLÓGICO E PROTOCOLO DOS EXPERIMENTOS ................................. 35

3.5.2 SÍNTESE DE cDNA A PARTIR DO RNA NÃO-AMPLIFICADO ........................................ 36

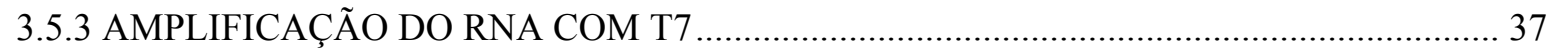

3.5.4 MARCAÇÃO POR ULS ${ }^{\mathrm{TM}}$ (UNIVERSAL LINKAGE SYSTEM), PURIFICAÇÃO E FRAGMENTAÇÃO DO aRNA . 
3.5.5 PREPARAÇÃO, PRÉ-HIBRIDAÇÃO E HIBRIDAÇÃO DAS LÂMINAS DE MICROARRAYS...

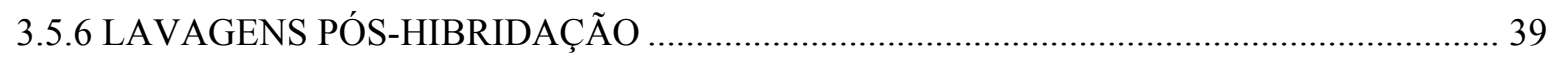

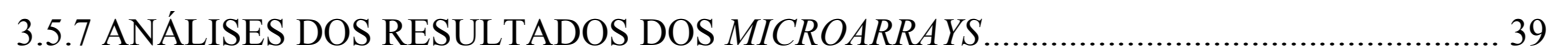

3.5.8 ANÁLISE DOS GENES COM EXPRESSÃO DIFERENCIAL ENTRE AS CASTAS ........ 39

3.6 PARA OS ESTUDOS DE SILENCIAMENTO UTILIZANDO INTERFERÊNCIA POR RNA (RNAi).

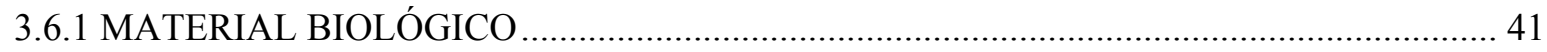

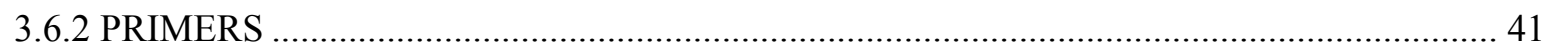

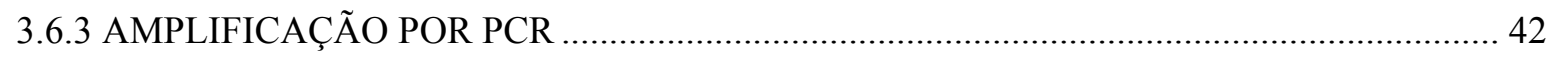

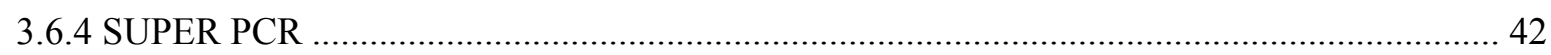

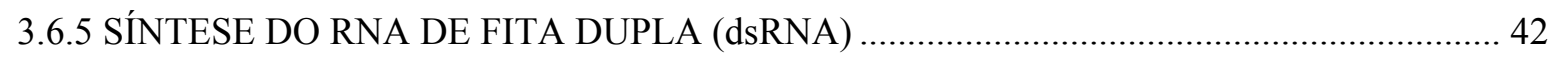

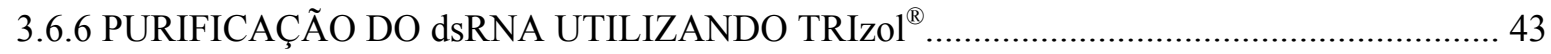

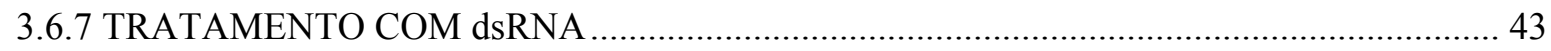

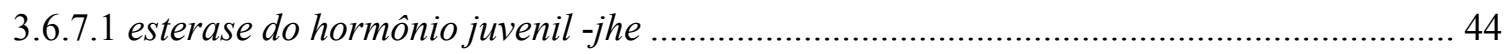

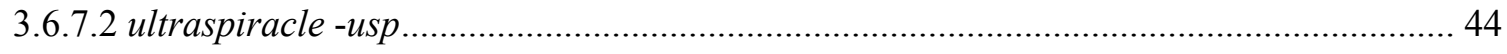

3.6.7.3 cryptocephal - crc e retinoid- and fatty acid-binding protein - RfaBp ............................. 44

3.6.7.4 PARA VERIFICAÇÃO DA EFICIÊNCIA DO SILENCIAMENTO............................... 44

3.7 IDENTIFICAÇÃO DOS miRNAS CANDIDATOS A REGULADORES DO GENE DA

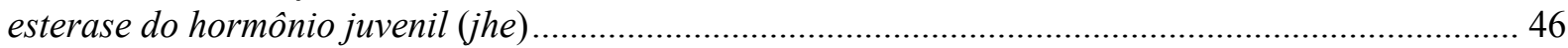

3.7.1 PREDIÇÃO DOS microRNAs REGULADORES DO GENE DA esterase do hormônio

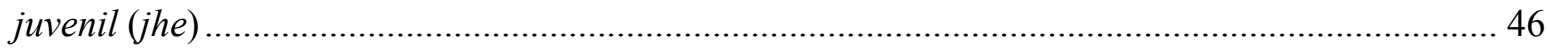

3.7.2 VALIDAÇÃO DA PREDIÇÃO DOS microRNAs REGULADORES DO GENE $j h e$........... 46

3.7.2.1 SÍNTESE DE cDNA A PARTIR DE miRNAs E QUANTIFICAÇÃO POR PCR

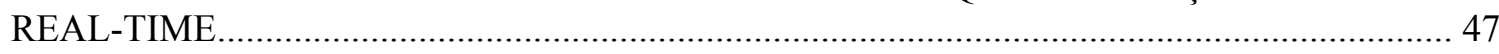

3.8 IDENTIFICAÇÃO DOS MIRNAS AFETADOS PELO SILENCIAMENTO DO GENE

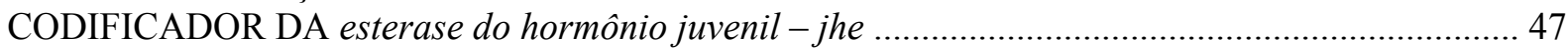

3.8.1 SEQUENCIAMENTO EM LARGA ESCALA DE PEQUENOS RNAs ............................... 47

3.8.2 ANÁLISE DAS BIBLIOTECAS GERADAS PELO SEQUENCIAMENTO EM LARGA

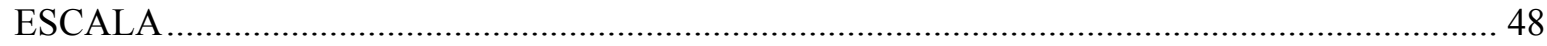

3.8.3 PREDIÇÃO DOS GENES REGULADOS PELOS MIRNAS AFETADOS PELO

SILENCIAMENTO DO GENE CODIFICADOR DA esterase do hormônio juvenil - jhe .............. 49

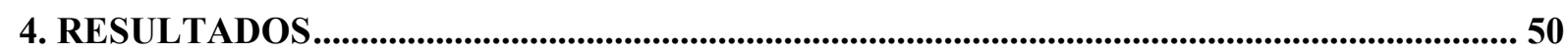

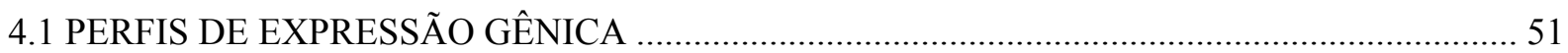

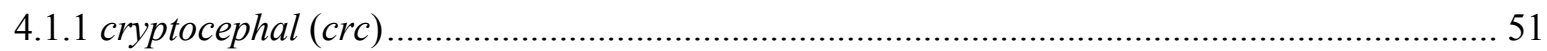

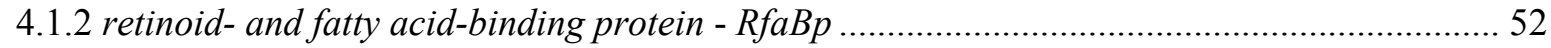

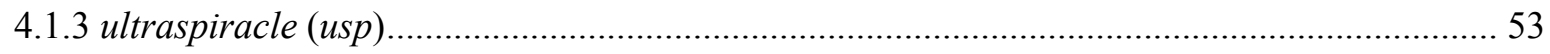

4.2 ANÁLISE DE EXPRESSÃO DIFERENCIAL POR MICROARRAYS ……............................... 54

4.3 ANÁLISE DO PERFIL DE EXPRESSÃO DO GENE CODIFICADOR DA esterase do hormônio juvenil (jhe)..... 


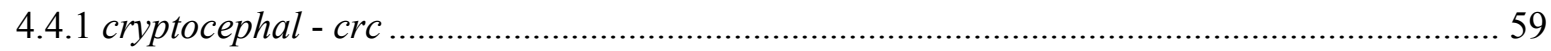

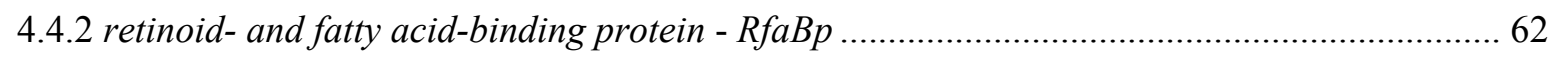

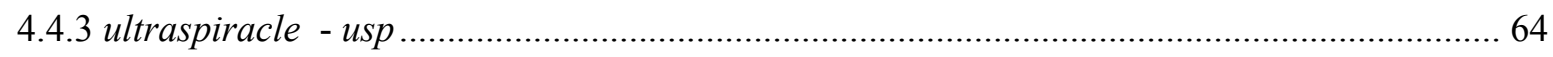

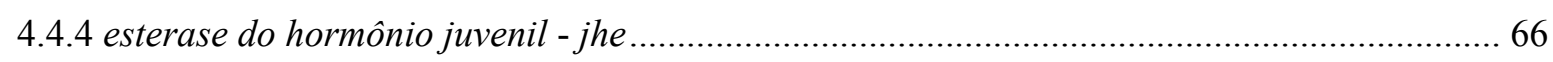

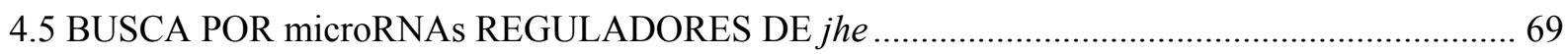

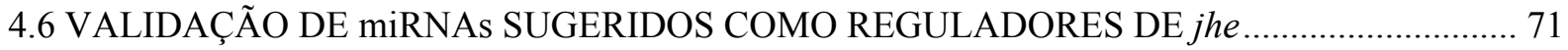

4.6.1 ESTUDOS DE EXPRESSÃO DOS miRNAs EM RAINHAS E OPERÁRIAS ..................... 71

4.6.2 ESTUDOS DE EXPRESSÃO DOS miRNAs EM AMOSTRAS KNOCK-DOWN PARA

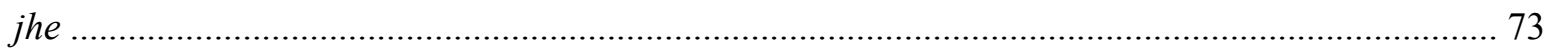

4.7 SEQUENCIAMENTO EM LARGA ESCALA DOS PEQUENOS RNAs ................................... 75

4.7.1 CARACTERIZAÇÃO DAS BIBLIOTECAS OBTIDAS ATRAVÉS DO

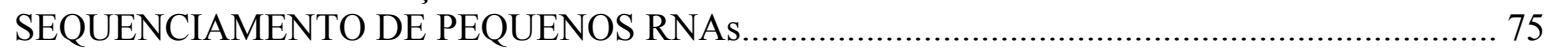

4.7.2. IDENTIFICAÇÃO DOS miRNAS DIFERENCIALMENTE EXPRESSOS NAS

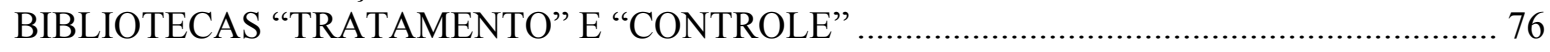

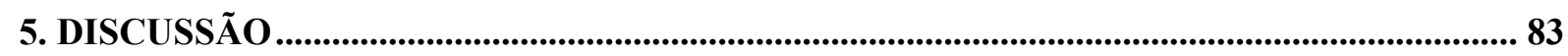

5.1 GENES ESPECIALMENTE ENVOLVIDOS NA DETERMINAÇÃO DE CASTAS................... 84

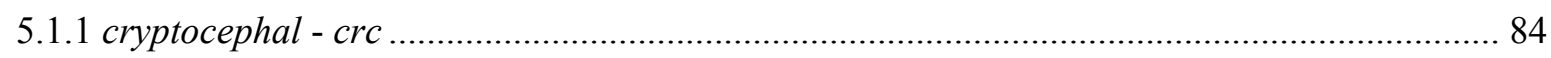

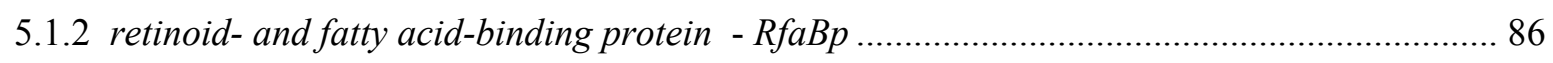

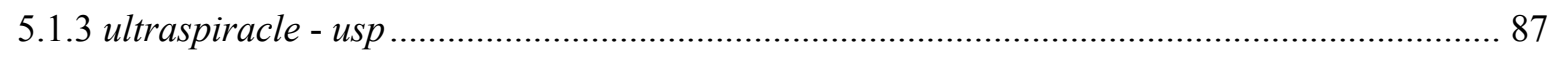

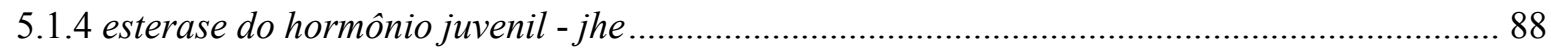

5.2 EXPRESSÃO GÊNICA GLOBAL NAS DIFERENTES CASTAS DE ABELHAS Apis

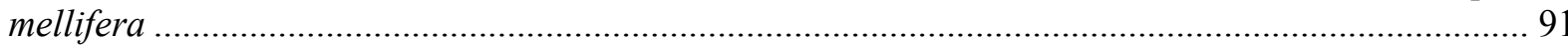

5.3 EFEITOS DO NOCAUTE DOS GENES ESPECIALMENTE ENVOLVIDOS NA DETERMINAÇÃO DE CASTAS SOBRE DIFERENTES PROCESSOS BIOLÓGICOS .................. 93

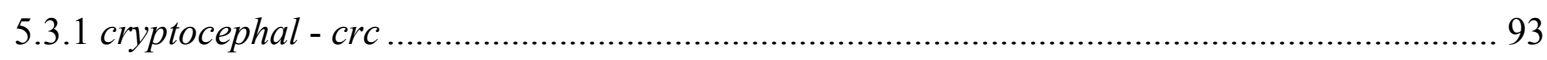

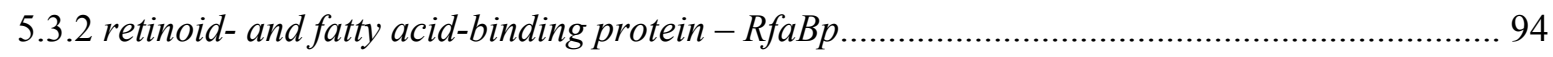

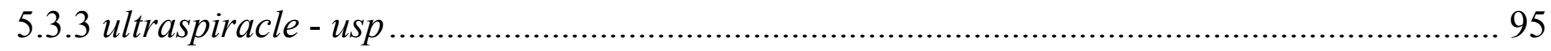

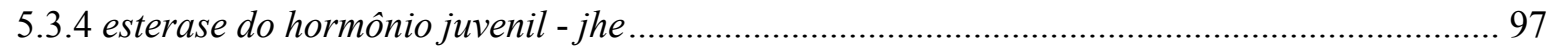

5.3.5 PANORAMA GERAL DAS INTERAÇÕES DESENCADEADAS PELO NOCAUTE DE GENES RELEVANTES NA DETERMINAÇÃO DE CASTAS .................................................... 98

5.4 ATUAÇÃO DOS microRNAs NO PROCESSO DE DETERMINAÇÃO DE CASTAS .............. 99

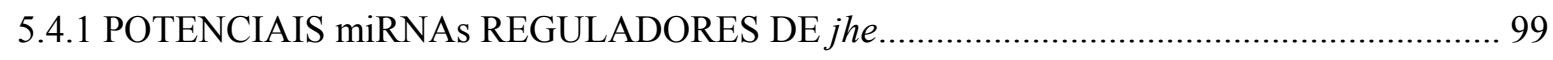

5.4.2 EXPRESSÃO DE miRNAS EM RAINHAS E OPERÁRIAS ….......................................... 101

5.4.3 EFEITOS DO NOCAUTE DE $j h e$ NO PADRÃO DE EXPRESSÃO DE miRNAS ............. 102

5.5 PROPOSIÇÃO DE NOVAS RELAÇÕES DENTRO DO MODELO DE DETERMINAÇÃO

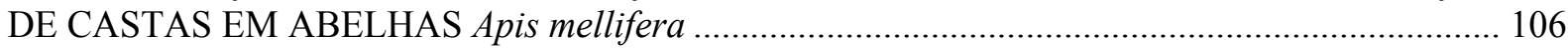


ANEXOS

ANEXO 1 - ORGANIZAÇÃO GÊNICA DE $c r c$, RfaBp, usp E jhe ................................................... 126

ANEXO 2 - RESULTADOS DE SEQUENCIAMENTO E ALINHAMENTOS DAS

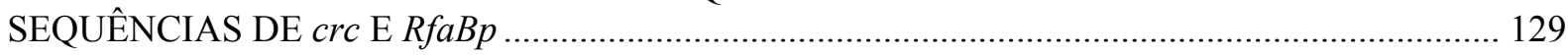

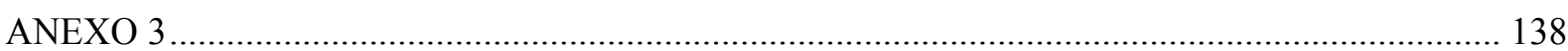

ANEXO 3A - LISTA DE GENES DIFERENCIALMENTE EXPRESSOS EM AMOSTRAS TRATADAS COM dsGFP E CONTROLE, OBTIDOS POR MICROARRAYS

ANEXO 3B - ANÁLISES DOS GENES DIFERENCIALMENTE EXPRESSOS EM AMOSTRAS dsGFP E CONTROLE

ANEXO 4 - EFEITOS DE dsGFP NA EXPRESSÃO DOS GENES ALVO DO TRATAMENTO

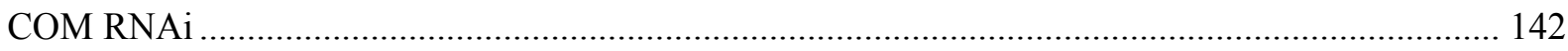

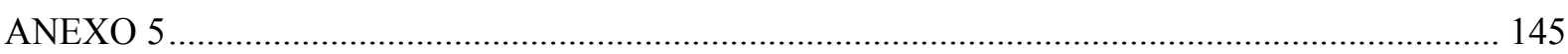

ANEXO 5A - TABELA DE GENES DIFERENCIALMENTE EXPRESSOS ENTRE RAINHAS E OPERÁRIAS NO QUARTO ESTÁGIO LARVAL, OBTIDOS POR MICROARRAYS.

ANEXO 5B -TABELA CONTENDO AS CATEGORIAS DE PROCESSOS BIOLÓGICOS NOS QUAIS OS GENES DIFERENCIALMENTE EXPRESSOS ENTRE RAINHAS E OPERÁRIAS NO QUARTO ESTÁGIO LARVAL ESTÃO ENVOLVIDOS DE ACORDO COM ANÁLISES DE GENE ONTOLOGY

ANEXO 6 - RESULTADOS DE EXPRESSÃO DIFERENCIAL DE mirNAS EM RAINHAS E OPERÁRIAS

ANEXO 7 - GENES DIFERENCIALMENTE EXPRESSOS EM RAINHAS E OPERÁRIAS COMPARTILHADOS NOS TRABALHOS ALEIXO SILVA (2012) E BARCHUK ET AL. (2007) 150

ANEXO 8 - PRIMEIRA VERSÃO DE MANUSCRITO A SER SUBMETIDO PARA PUBLICAÇÃO 


\subsection{CONSIDERAÇÕES GERAIS SOBRE DETERMINAÇÃO DE CASTAS EM Apis mellifera}

As abelhas Apis mellifera são insetos eussociais pertencentes à ordem Hymenoptera. A definição de eussocialidade inclui divisão de trabalho entre indivíduos, específicos de cada casta, o cuidado com a prole e a sobreposição de gerações, que determinam o bom funcionamento de uma colônia (Gullan \& Cranston, 1994). O dimorfismo de castas, presença de rainha e operárias, uma das características dos insetos sociais, também está presente nas abelhas $A$. mellifera. As rainhas, cuja principal função em uma colônia é a reprodução, possuem o sistema reprodutivo bem desenvolvido, espermateca funcional e taxas reprodutivas altas. Tipicamente existe uma rainha por colônia que é capaz de pôr mais de 2.000 ovos por dia. As operárias são responsáveis por desempenhar tarefas que promovem a manutenção da colônia, incluindo alimentação da cria e da rainha, construção de favos, coleta e processamento do alimento, defesa e limpeza da colônia, entre outras. Elas são facultativamente estéreis, seu aparelho reprodutor é pouco desenvolvido e parcialmente substituído pelo aparelho ferroador, o que as incapacita de serem fecundadas. As operárias apresentam características morfológicas que não são encontradas em rainhas de sua espécie, incluindo órgãos de defesa e sensoriais, além dos ligados às mudanças comportamentais, relacionados com as tarefas que desenvolverão ao longo de suas vidas, como a coleta de pólen, por exemplo (Wilson, 1971; Michener, 1974). Elas estão presentes normalmente em dezenas de milhares por colônia e apresentam habilidades cognitivas sofisticadas (Witthöft, 1967).

Nesta espécie de abelha, considerada modelo para desenvolvimento de castas e divisão de trabalho em Hymenoptera sociais, o principal fator responsável pelo dimorfismo das fêmeas é a nutrição diferencial da larva, durante os primeiros dias de desenvolvimento pós-embrionário. Uma mesma larva pode dar origem a uma rainha ou a uma operária. Dependendo do tipo e da quantidade recebida pela larva, o alimento exerce seu papel disparando uma resposta endócrina característica, que se manifesta por elevados títulos de hormônio juvenil (HJ) em larvas que se tornarão rainhas (Rachinsky et al., 1990). Até o segundo estágio larval, todas as larvas recebem geléia real como alimento, após este período, as larvas destinadas a se tornarem rainhas continuam recebendo uma dieta composta por este produto da glândula mandibular de 
operárias até o final do período de alimentação, o final do estágio larval, enquanto que aquelas destinadas a se tornarem operárias têm sua dieta substituída por uma mistura de secreções glandulares, mel e pólen (Rembold, 1987; Laidlaw, 1992). Além disto, as larvas que se tornarão rainhas recebem 10 vezes mais alimento que as larvas que se tornarão operárias (Jung-Hoffmann, 1966). No final do terceiro estágio larval, os corpora allata das larvas de rainhas prospectivas tornam-se bem maiores que aqueles encontrados nas larvas destinadas a serem operárias (Dogra et al., 1977). Estes órgãos são responsáveis pela síntese do hormônio juvenil, que começa a apresentar níveis substancialmente mais altos nas larvas cujo destino é se tornarem rainhas (Rachinsky et al., 1990). O período entre o terceiro e o quarto estágio larval (96 horas após emergência) é crítico na determinação de castas e está caracterizado pela divergência dos programas de diferenciação de rainhas e operárias (Goewie, 1978), marcada pela expressão gênica diferencial (Barchuk et al., 2007).

Conceitualmente, o processo de diferenciação de castas envolve dois tipos de alterações no modelo original de desenvolvimento: (I) alterações que afetam o crescimento geral do corpo ou de órgãos específicos, dando origem a rainhas. Este crescimento pode ser exemplificado pelos ovários, que apresentam de 150 a 180 ovaríolos em rainhas adultas, enquanto que, em operárias adultas é composto por apenas 2 a 12 ovaríolos funcionais, este número pode variar, dependendo da linhagem considerada. (II) alterações no estado de caráter que resultam na presença ou ausência de estruturas específicas, como o aparelho coletor de pólen, a corbícula, presente no terceiro par de pernas das operárias e ausente em rainhas, assim como outras estruturas, como as glândulas de cera, por exemplo, também características de operárias. Os dois tipos de alterações fazem parte das respostas aos níveis de HJ que, altos em rainhas e baixos em operárias, controlam a expressão de genes envolvidos no desenvolvimento de órgãos específicos e na especificação do plano corporal geral.

Após o período em que o destino larval é decidido, não apenas as características morfológicas passam a diferenciar rainhas de operárias, a fisiologia, o comportamento e os padrões de expressão gênica também serão muito distintos entre as castas (Severson et al., 1989; Corona et al., 1999; Evans \& Wheeler, 1999; 2001; Hepperle \& Hartfelder, 2000; Guidugli et al., 2004; Corona et al., 2005, Barchuk et al., 2007; Maleszka, 2008). Estes autores, entre outros, tem contribuído para a construção de um modelo que pretende explicar a determinação e desenvolvimento das castas de A. mellifera. 


\subsection{MODELO UNIFICADO DA DETERMINAÇÃO DE CASTAS EM Apis mellifera}

Barchuk et al. (2007) propuseram um modelo para a determinação de castas em A. mellifera baseado na análise da expressão gênica diferencial entre rainhas e operárias durante o período crítico do desenvolvimento, entre o terceiro e o quarto instar larval. Estes autores propõem que o estímulo nutricional é captado pelo sistema nervoso estomatogástrico (Boleli et al., 1998), que envia a informação ao cérebro e ao sistema endócrino. Então, ocorre a regulação da atividade dos corpora allata (CA) e dos tecidos alvos por moléculas da via insulina/IGF (insulin-like growth factor), provavelmente secretadas pelas células neurossecretoras do gânglio cerebral larval (Wheeler et al., 2006). O corpo gorduroso recebe a informação através da hemolinfa, o que, em rainhas, resultará na ativação dos sistemas insulina/IGF e TOR (target of rapamycin) que são sensíveis à disponibilidade de nutrientes e níveis de energia e controlando assim a divisão celular e crescimento, segundo modelo proposto por Colombani et al. (2003) e Oldham \& Hafen (2003). Desta maneira, nos corpora allata, a ativação da via de TOR pode levar à síntese de HJ, um dos reguladores centrais do desenvolvimento dos insetos, ativando a via de comunicação sistêmica mediada por ALS (o ortólogo de mamíferos da acid labile subunit), no corpo gorduroso, que sinaliza para outros tecidos larvais, de maneira dependente de PI3K (phosphoinositide-3-kinase), a situação nutricional favorável do organismo (Colombani et al., 2003). Outros órgãos sensíveis a esta sinalização são os ovários, que respondem com proliferação celular ao ambiente nutricional (Drummond-Barbosa \& Spradling, 2001).

Em resposta aos altos títulos de $\mathrm{HJ}$ as rainhas prospectivas regulam positivamente a expressão de genes fisiometabólicos que, juntamente com os nutrientes provenientes da geléia real, determinam o padrão de crescimento corporal. O alimento oferecido às operárias, por outro lado, afeta a via insulina/IGF de uma maneira menos pronunciada e pode não promover o aumento nos níveis de HJ acima de um limiar específico (Barchuk et al., 2007). Portanto, o desenvolvimento de rainhas e operárias pode estar condicionado por altos e baixos sinais de AmTOR durante o período larval, fato demonstrado por Barchuk e colaboradores (2007) e Patel e colaboradores (2007) que determinaram níveis de mRNA codificador de AmTOR como sendo duas vezes maiores em rainhas que os apresentados por larvas destinadas a serem operárias neste mesmo estágio. A regulação positiva de tor em larvas de rainhas pode ser vista como um determinante da taxa de crescimento diferencial podendo 
constituir um dos componentes principais dos mecanismos genéticos responsáveis pela determinação de castas em A. mellifera (Figura 1).

Maleszka (2008) propôs um modelo que adiciona elementos ao acima descrito, a metilação diferencial do DNA nas castas femininas. Para ele, as alterações fenotípicas fundamentais à organização social em insetos, com certas exceções (Hartfelder et al., 2006), são determinadas pelo ambiente (Wilson, 1971; Hartfelder \& Engels, 1998; Evans \& Wheeler, 2001). A determinação ambiental então implicaria na existência de um controle epigenético, que foi analisado através do silenciamento de uma enzima responsável pela transferência de um radical metil ao DNA, a Dnmt3 (DNA metiltransferase-3) (Maleszka, 2008). A diminuição dos níveis de transcrição desta enzima induziu o desenvolvimento dos ovários e a redução da metilação das ilhas $\mathrm{CpG}$. Adicionalmente, análises por microarrays utilizando as amostras knockdown para Dnmt3 mostraram a regulação positiva de genes envolvidos no crescimento e metabolismo (genes fisio-metabólicos). Portanto, de acordo com Maleszka (2008), a diminuição nos níveis desta enzima mimetizou os efeitos da geléia real, sobre os processos envolvidos no desenvolvimento larval que determina o destino das fêmeas de A. mellifera. Estes resultados provêem uma evidência experimental de que a metilação do DNA é utilizada para armazenar informação epigenética e controla, nesta abelha, os estados herdáveis de expressão gênica. Desta maneira, o autor conclui que grande parte da determinação comportamental em A. mellifera é epigenética e envolve a integração de redes disparadas pelo estímulo nutricional diferencial que determinarão o destino larval (Figura 2).

Recentemente, foi descoberta uma proteína componente da geléia real, responsável pelo desenvolvimento de caracteres específicos de rainhas, adicionando mais um componente ao modelo de determinação de castas. Esta proteína, royalactin, possui efeitos semelhantes ao egf (epidermal growth factor) (Kamakura et al., 2001; Kamakura, 2002) e além disto, foi observado que em abelhas ela é capaz de reduzir o tempo de desenvolvimento e elevar o peso do adulto, o tamanho dos ovários e ainda os títulos de $\mathrm{HJ}$, sugerindo que o efeito da royalactin na determinação de castas não é apenas nutricional, mas sim morfogênico, e que esta proteína é o principal fator ativo neste processo desencadeado pela geléia real (Kamakura, 2011) (Figura 3). 


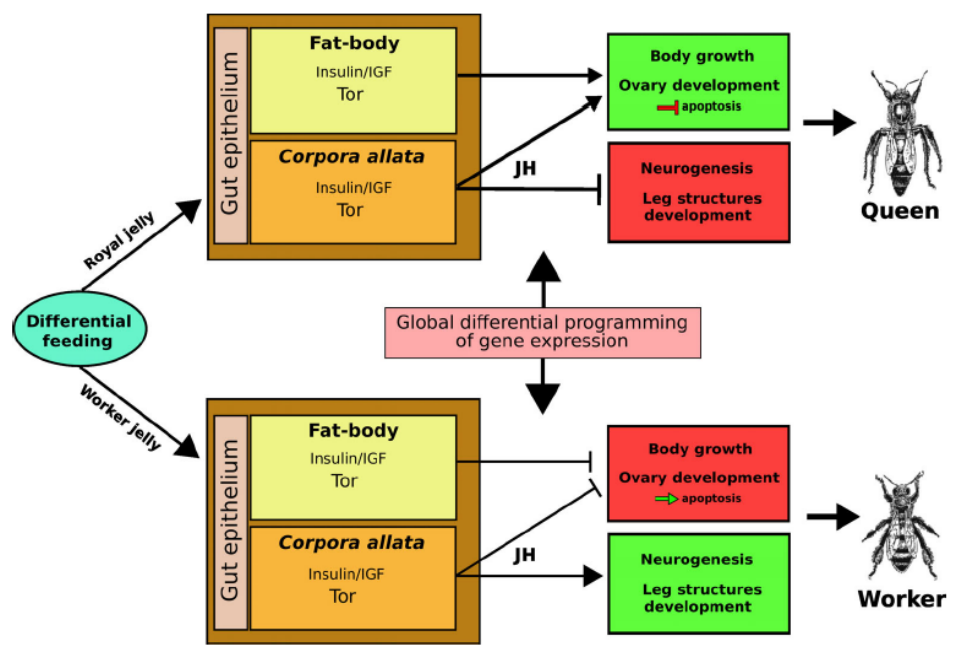

Figura 1: Modelo de diferenciação de castas proposto por Barchuk et al. (2007). Espessura das setas indica os níveis relativos de ação dos fatores considerados.

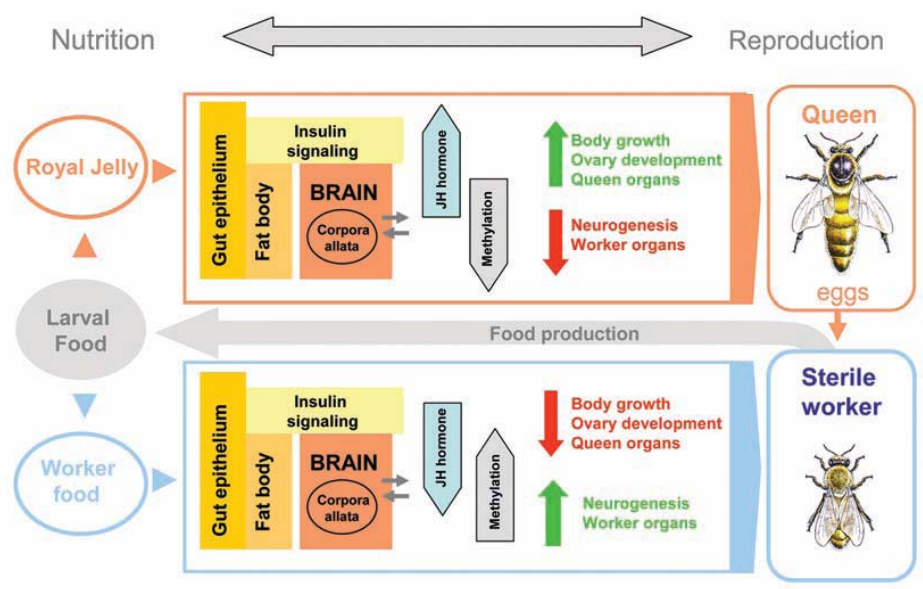

Figura 2: Eixo nutrição-cérebro-reprodução no desenvolvimento de abelhas Apis mellifera. O alimento larval é reconhecido pelo epitélio intestinal e metabolizado no corpo gorduroso. Sinais são enviados ao cérebro pela via de insulina levando à liberação de Hormônio Juvenil (HJ) pelas células dos corpora allata. Os níveis de HJ são altos em larvas prospectivas de rainhas e baixos em larvas que se tornarão operárias. Em contraste, os níveis de metilação do DNA são mais elevados em operárias. Os resultados fenotípicos são manifestados por características anatômicas e fisiológicas contrastantes nas castas. Como as operárias estéreis são as responsáveis pela produção do alimento larval, o processo como um todo forma um ciclo firmemente controlado. (Maleszka, 2008). 


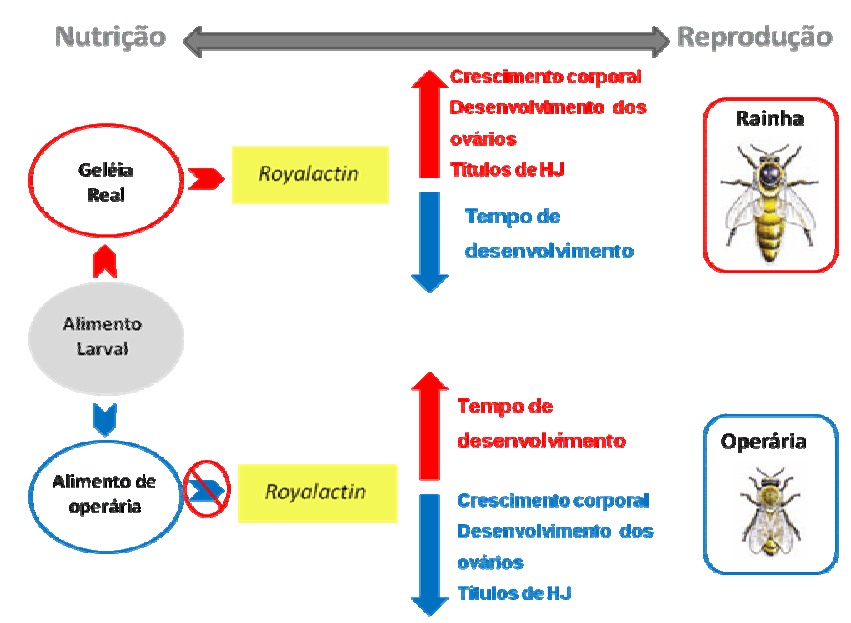

Figura 3: Modelo de determinação de castas baseado no que foi proposto por Kamakura (2011), em que a royalactin exerceria um papel fundamental no destino larval, favorecendo o desenvolvimento de rainhas agindo de forma semelhante ao egf (epidermal growth factor) na determinação do tamanho corporal e, além disto, acelera o desenvolvimento de um modo geral, o desenvolvimento dos ovários e o aumento significativo nos títulos de Hormônio Juvenil.

\subsection{GENES POTENCIALMENTE ENVOLVIDOS NA DETERMINAÇÃO DE OPERÁRIAS EM Apis mellifera}

A recente descoberta da royalactin mostra seu papel na determinação de castas, especialmente seu envolvimento em processos que culminam na diferenciação de rainhas (Kamakura, 2011). Porém, pouco se sabe sobre possíveis genes ou vias de sinalização que direcionam o desenvolvimento de uma larva para que esta se torne uma operária. Expressão gênica diferencial durante o período larval em abelhas tem sido relatada há algum tempo (Severson et al., 1989), mas a identificação de genes envolvidos neste processo é relativamente recente (Evans \& Wheeler, 1999; Corona et al., 1999; Hepperle \& Hartfelder, 2000; Barchuk et al., 2007). Estes genes estão possivelmente envolvidos em processos característicos do surgimento de castas, entre eles estão os processos metabólicos, nutricionais e de sinalização durante o desenvolvimento (Evans \& Wheeler, 2000; Barchuk et al., 2007), apoptose ou desenvolvimento de tecidos reprodutivos e a taxa de desenvolvimento (Evans \& Wheeler, 2001).

Através de experimentos de expressão gênica diferencial em larga escala (microarrays), foram encontrados 240 genes diferencialmente expressos nas castas de A. mellifera. Entre estes genes estão ultraspiracle (usp - GB16648), cryptocephal (crc - GB19338) e RfaBp (RfaBp - retinoid-and fatty acid-binding protein ou lipoforina lp - GB11059), positivamente regulados em operárias (Barchuk et 
al.; 2007). A presença nestes genes de sítios de ligação para os receptores nucleares USP e EcR (Christianson et al., 1992; Perera et al., 2005) pode estar envolvida com sua regulação positiva em operárias além de sugerir uma ação conjunta destes genes. Estes resultados indicam a possível atuação de $u s p$, $c r c$ e $R f a B p$ na determinação de operárias, desempenhando um importante papel na regulação de mudanças fenotípicas essenciais na diferenciação de castas em abelhas. Além destes, o gene codificador da esterase do hormônio juvenil (jhe) foi também sugerido como possível determinante de operárias, com base nos resultados obtidos durante a execução deste trabalho e também na função deste gene na regulação dos níveis de HJ, fundamental para o desenvolvimento e determinação de castas em A. mellifera.

\subsection{1 cryptocephal - crc}

O gene $\operatorname{crc}$ codifica uma proteína membro da família CREB/ATF4 de fatores de transcrição bZIP (basic-leucine zipper), que participa de um mecanismo conservado sensor de privação de aminoácidos e indutor de estresse (Jousse et al., 2004) e que age como reguladora do desenvolvimento de pernas (Kojima, 2004). Além disto, está envolvida no mecanismo de emergência da cabeça em insetos, que ocorre normalmente pela contração da musculatura abdominal da pré-pupa que ocasiona a emersão da cabeça prospectiva (Fristrom, 1965).

Em Drosophila, crc é um gene de cópia única que codifica pelo menos seis mRNAs e três proteínas diferentes (isoformas). Estas isoformas possuem funções distintas, mas que se sobrepõem. Este gene se expressa diferencialmente nos tecidos e órgãos, sendo mais expresso nos discos imaginais e no sistema nervoso central (Hewes et al., 2000). CRC desempenham importante papel na regulação da muda larval em Drosophila e sugere-se que ela possa estimular a biossíntese da ecdisona nas células da glândula protorácica e exercer seu papel em tecidos que respondem a este hormônio (Hewes et al., 2000). Além da ecdisona, crc parece controlar os níveis de outros hormônios como, por exemplo, o ETH (ecdysis triggering hormones) estimulando também sua síntese (Gauthier \& Hewes, 2006). Foi observado que $c r c$ em abelhas é preferencialmente expresso em operárias e que juntamente com tor e creg, pode constituir um sistema duplo de regulação do crescimento em resposta a alimentação diferencial (Barchuk et al., 2007). 


\subsection{2 retinoid- and fatty acid-binding protein ou lipoforina (RfaBp ou Ip)}

A Lipoforina (Lp) é uma lipoproteína que, em insetos, é reconhecida principalmente por sua capacidade de transportar lipídios (Van Heusden \& Law, 1989) e vários outros ligantes hidrofóbicos, como por exemplo, o HJ (Trowell, 1992; Engelmann \& Mala, 2005) e retinóides (Kutty et al., 1996) entre os diversos tecidos, através da hemolinfa. A Lp participa também dos processos reprodutivos dos insetos, principalmente na ovogênese, agindo como molécula transportadora de lipídios entre o corpo gorduroso e os ovários e como proteína do ovo acumulada nos ovócitos (Kawooya \& Law, 1988; Telfer et al., 1991; Sun et al., 2000; Yun et al., 1994; Engelmann \& Mala, 2005; Colonello-Frattini et al., 2010). Lp é composta por lipídios e duas apolipoproteínas, a apoLp - I (210-250 kDa) e a apoLp II (70-85 kDa) (Ryan et al., 1984; Venkatesh et al., 1987; Weers et al., 1993; Van Heusden et al., 1998; Sevala et al., 1999; Sun et al., 2000; Fan et al., 2004). Em Drosophila, a proteína RfaBp possui características relacionadas a lipoforinas, tais como ser composta por subunidades, capacidade de se ligar tanto com retinóides quanto com lipídeos com alta afinidade, conter ácidos graxos endógenos, como algumas proteínas desta família, por exemplo a RfaBG (retinoid-and fatty acid-binding glycoprotein). O gene codificador desta proteína tem sua expressão dependente dos níveis de hormônio e é expresso preferencialmente na amnioserosa, corpo gorduroso e apodeme (uma estrutura interna ao exoesqueleto que suporta órgãos internos e provê pontos onde os músculos se inserem) de embriões de Drosophila. Assim como a Lp, RfaBp desempenha um importante papel no transporte de lipídeos, incluindo retinóides e ácidos graxos (Kutty et al., 1996). Em operárias de A. mellifera, este gene é considerado um marcador da fase alimentadora. Quando este gene é regulado positivamente, a operária continua dentro da colônia desempenhando o papel de cuidado com as crias, ao invés de ir pra campo realizar a atividade forrageira (Whitfield et al., 2006).

\subsection{3 ultraspiracle (usp)}

O gene usp, pertence à superfamília dos receptores nucleares de hormônios. Receptores nucleares são fatores de transcrição ligante-dependentes responsáveis por controlar diferenciação, crescimento e desenvolvimento em eucariotos mais derivados (Grad et al., 2002; Patrick et al., 2001). 
Eles fornecem aos organismos uma maneira de controlar diretamente a expressão gênica em resposta a uma grande variedade de estímulos físiológicos e ambientais e sinais hormonais (Chawla et al., 2001). usp dá origem a uma proteína que pode ser dividida em quatro ou cinco módulos conhecidos como domínios com funções distintas, mas complementares (Mangelsdorf et al., 1995; Henrich et al., 1995; Giguère, 1999; Umesono \& Evans, 1989; Grad et al., 2002; Zechel et al., 1994; Perlmann et al., 1993; Billas et al., 2003; Evans, 1988; Green \& Chambon, 1988; Beato, 1989).

Os receptores nucleares, para se tornarem ativos, formam complexos homodiméricos e/ou heterodiméricos que reconhecem sequências específicas no DNA que estão dispersas pelo genoma e regulam a expressão de genes adjacentes em combinação com outros fatores de transcrição (Truss \& Beato, 1993; Cherbas, 1993). USP de insetos é ortólogo ao receptor de retinóide X (RXR) de vertebrados (Oro et al., 1990). Assim como RXR e outros receptores nucleares, para se tornar um receptor ativo USP se heterodimeriza com o receptor de ecdisona (EcR), formando o complexo USP/EcR, essencial na ligação da ecdisona, que controla o desenvolvimento, reprodução, muda e metamorfose (Yao et al., 1993).

Em Apis mellifera, usp (Amusp) está presente como um gene de cópia única que dá origem a dois transcritos diferentes por splicing alternativo (um com aproximadamente $4 \mathrm{~kb}$ e outro com aproximadamente $5 \mathrm{~kb}$ ). Estes transcritos são considerados isoformas de USP e se expressam diferencialmente no corpo do animal. A sequência da proteína de AmUSP possui a típica organização protéica dos membros da superfamília dos receptores nucelares e, além disso, tem um alto nível de similaridade com USP de outros insetos (Jindra et al., 1997; Kapitskaya et al., 1996; Vögtli et al., 1999).

usp desempenha um papel fundamental no desenvolvimento e metamorfose (Sasorith et al., 2002), integrando múltiplos caminhos de sinalização (Hall \& Thummel, 1998). Ele era considerado um receptor órfão (Tsai \& O’Malley, 1994), mas estudos recentes sugerem sua capacidade ativação da transcrição por meio da união com HJ (Xu et al., 2002; Barchuk et al., 2004). Visto que o desenvolvimento de todos os artrópodes é hormonalmente regulado de uma maneira semelhante por ecdisteróides, hormônios juvenis e seus precursores, estas observações permitem aventar a hipótese de USP ser um receptor de HJ (Iwema et al., 2007). 
Através de estudo envolvendo expressão gênica diferencial, foi observado que, entre outros genes, usp é diferencialmente expresso entre rainhas e operárias nas fases L3 (instar larval 3) e L4 (instar larval 4) (Barchuk et al., 2007) fases chave na determinação de castas em A. mellifera. De acordo com o que foi observado, ele é regulado positivamente em operárias e pode estar regulando outros genes, como cryptocephal ( $c r c)$ e retinoid- and fatty acid-binding protein ( $R f a B p)$, também preferencialmente expressos nesta casta (Evans \& Wheleer, 1999, 2000; Barchuk et al., 2007).

\subsection{4 esterase do hormônio juvenil (jhe)}

O Hormônio Juvenil (HJ), juntamente com o ecdisteróide, 20-hidroxiecdisona (20E), está entre os principais hormônios que regulam o desenvolvimento de insetos. Ele age modulando a ação de $20 \mathrm{E}$ e prevenindo a metamorfose (Riddiford, 1996). Além disso, como mencionado anteriormente, HJ desempenha um papel fundamental na determinação de castas em A. mellifera, apresentando níveis elevados em larvas destinadas a se tornarem rainhas (Rachinsky et al., 1990). Durante a metamorfose, e no processo de determinação de castas, os níveis de HJ na hemolinfa são modulados principalmente pelos processos de síntese e degradação (Gilbert et al., 2000), em momentos precisos do desenvolvimento.

A regulação da síntese é considerada de extrema importância e, em insetos, esta via envolve a formação de dois importantes precursores, o mevalonato, e o farnesil difosfato (Bellés et al., 2005). A degradação, outro importante processo modulador dos níveis de HJ, ocorre através de uma intensa atividade hidrolítica que retira o hormônio de circulação (Hinton \& Hammock, 2001), em momentos cruciais do desenvolvimento e determinação de castas. A esterase do HJ (JHE) e a epóxido hidrolase do HJ (JHEH) são as principais enzimas de degradação do HJ. A JHE está presente na hemolinfa e nos tecidos, enquanto a JHEH está ligada a tecidos específicos e primariamente associada à fração microssomal (de Kort \& Granger, 1996; Mackert et al., 2008).

A esterase do Hormônio Juvenil (JHE) desempenha um papel crucial no metabolismo deste hormônio e tem sido estabelecida há longo tempo como regulador negativo de seus títulos (Sparks et al., 1983; Hammock, 1985). Os altos níveis de HJ durante estágios específicos do desenvolvimento 
parecem ativar a expressão de jhe no corpo gorduroso, principal órgão de síntese da proteína que é liberada na hemolinfa, onde hidrolisa o HJ (Weirich et al., 1973). Devido à sua alta especificidade por este hormônio, mesmo em pequenas quantidades a JHE é suficiente para hidrolisar o HJ presente na hemolinfa (Ward et al., 1992). À JHE foi atribuída a função de reguladora dos títulos de HJ modulando a taxa de degradação (Hammock, 1985), mas visto que os níveis máximos de jhe ocorrem apenas após o declínio dos títulos de HJ, de acordo com o que foi observado para Manduca sexta (Baker et al., 1987; de Kort \& Granger, 1996) e A. mellifera (Mackert et al., 2008), podemos sugerir que a JHE seja importante para eliminar os traços remanescentes de HJ na hemolinfa, processo necessário para preparação para a metamorfose (Baker et al., 1987; De Kort \& Granger, 1996).

Como já mencionado anteriormente, além de seu papel crucial na metamorfose, JHE pode também desempenhar um papel fundamental, juntamente com outros genes, na diferenciação das castas em A. mellifera, regulando os níveis de HJ. Este gene, juntamente com aqueles descritos anteriormente, $R f a B p$, usp e $c r c$, pode desempenhar um importante papel no desenvolvimento diferencial das castas em A. mellifera. Eles parecem atuar na regulação de mudanças fenotípicas no desenvolvimento destas abelhas influenciando vias de sinalização disparadas anteriormente pela alimentação diferencial. Portanto, informações sobre o mecanismo de ação destes genes, sobretudo nestas vias sinalizadoras nas quais possivelmente atuam, seria vantajoso na compreensão dos mecanismos moleculares responsáveis pelo surgimento de diferentes fenótipos a partir de um mesmo genótipo. 


\subsection{OBJETIVOS GERAIS}

- Determinar fatores moleculares potencialmente envolvidos no processo de determinação castas em Apis mellifera, com ênfase naqueles que participam da via responsável pela diferenciação de operárias;

- Analisar a participação de genes específicos neste processo.

\subsection{OBJETIVOS ESPECÍFICOS}

- Determinar expressão gênica diferencial em rainhas e operárias durante a determinação de castas através de microarrays;

- Descrever e analisar o perfil de expressão dos genes $c r c$, RfaBp, usp e jhe de Apis mellifera durante o desenvolvimento das castas femininas de A. mellifera;

- Analisar o papel de cada um destes genes no processo de desenvolvimento e determinação de castas através de silenciamento gênico;

- Avaliar a influência do knockdown sobre a expressão dos outros genes relacionados;

- Buscar moléculas reguladoras de jhe (microRNAs) que possam explicar a expressão diferencial da jhe nas castas fêmeas de Apis mellifera;

- Analise do perfil de expressão dos miRNAs sugeridos como reguladores de jhe em rainhas e operárias;

- Validação dos miRNAs em amostras knockdown para jhe;

- Avaliação da expressão diferencial por sequenciamento em larga escala dos miRNAs de amostras knockdown para o gene jhe e amostras controle;

- Análise funcional dos miRNAs diferencialmente expressos de acordo com o sequenciamento em larga escala. 
3. MATERIAL E MÉTODOS 

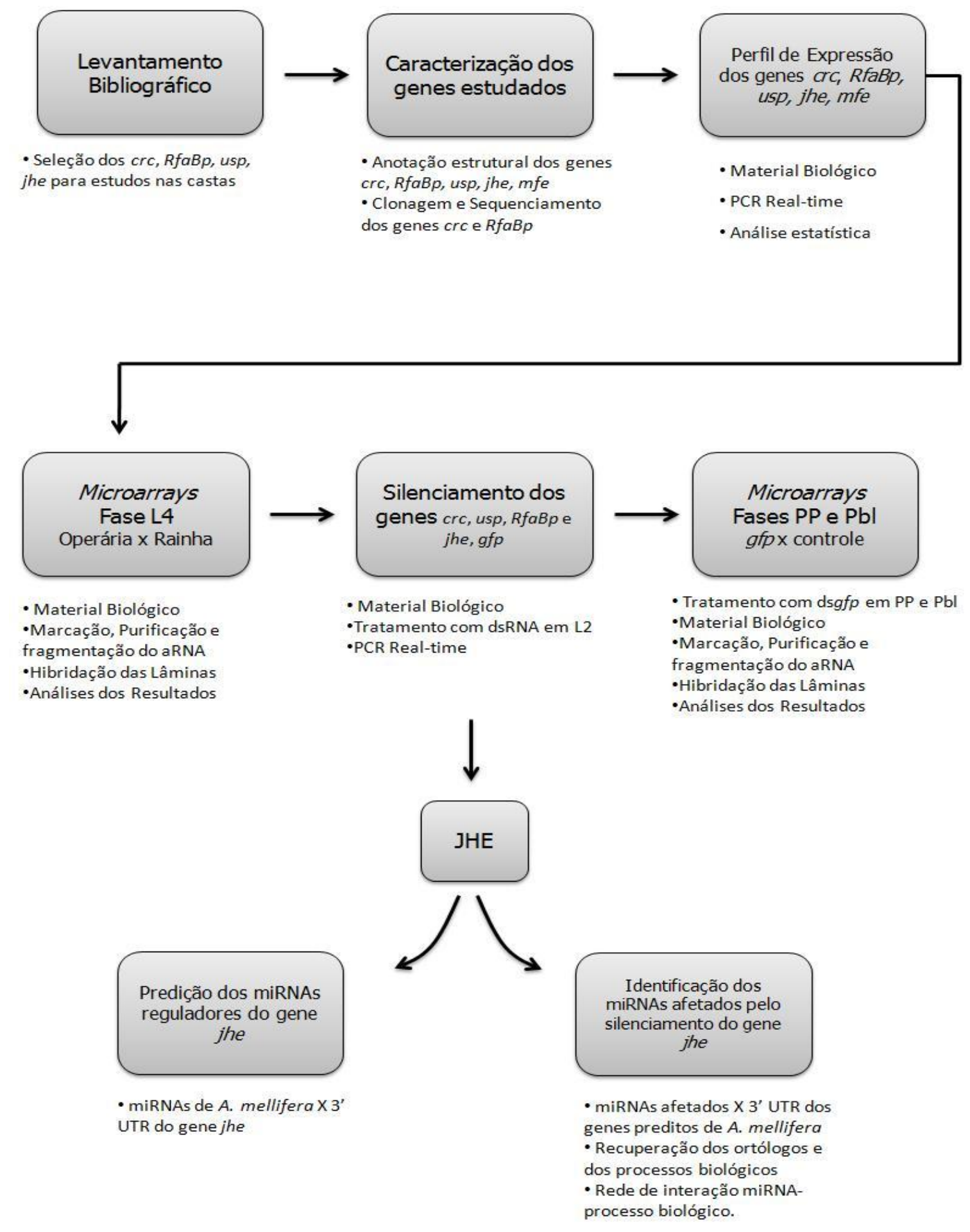

Figura 4: Organização do desenvolvimento da metodologia utilizada na realização deste trabalho, contendo as principais técnicas utilizadas na tentativa de se alcançar os objetivos propostos. 


\subsection{ANÁLISE IN SILICO}

Uma versão disponível do genoma de $A$. mellifera (versão 4.0 - http://zulu.fimrp.usp.br/beelab), bastante completa e com sequências codificadoras preditas (Official Set http://www.hgsc.bcm.tmc.edu/projects/honeybee/) facilitou a anotação dos genes de interesse. Como crc, $R f a B p$ ainda não foram descritos em abelhas, os GBs destes genes e o grupo ao qual pertencem foram obtidos com base na sequência preditas destes genes e com o auxílio de suas ESTs (Expressed Sequence Tag) de Drosophila $\quad(R f a B p \quad-\quad$ http://flybase.bio.indiana.edu/cgibin/getseq.html?source=dmel\&id=FBgn0087002\&chr=4\&dump=PrecompiledFasta\&targetset=gene_e $c r c$ http://flybase.bio.indiana.edu/cgibin/getseq.html? source=dmel\&id=FBgn0000370\&chr=2L\&dump=PrecompiledFasta\&targetset=gene) Para os genes usp e jhe, cujas sequências encontram-se disponíveis no GenBank, os seus GBs grupos foram obtidos utilizando estas sequências (usp - número de acesso no GenBank NP_001011634; jhe - número de acesso no GenBank NP_001011563.1). Tais informações relativas a cada um destes genes eram obtidas utilizando a ferramenta BLAST (http://zulu.fmrp.usp.br/beelab/beelab/bioinfo_blast), e as sequências relativas aos GBs e grupos encontrados eram obtidas por outra ferramenta disponível neste site (http://zulu.fmrp.usp.br/beelab/beelab/bioinfo_extraiseq). A partir destas sequências, a proteína correspondente era mapeada no genoma, novamente através de um BLAST e a partir destas informações a anotação era feita utilizando o programa Artemis (Sanger Institute http://www.sanger.ac.uk/Software/Artemis/), que nos permitia visualizar a conformação em íntrons e éxons do gene, bem como o número de nucleotídeos que compunha cada um (Anexo 1).

\subsection{DESENHO DE PRIMERS}

Foram desenhados primers específicos para cada gene estudado e também de acordo com o experimento em que foi utilizado. $\mathrm{O}$ design destes primers foi feito utilizando as sequências anotadas destes genes, levando em consideração os diferentes éxons, isto é, sempre que possível um par de primers era desenhado utilizando dois ou mais éxons diferentes para que, como era utilizado apenas cDNA nos experimentos, uma possível contaminação com DNA genômico pudesse ser descartada. O programa Primer3 (v 0.4 .0 - http://frodo.wi.mit.edu/primer3), disponível online, foi utilizado no design de todos os primers utilizados neste trabalho e suas sequências encontram-se na Tabela 1. 
Tabela 1: Primers utilizados nos diversos experimentos realizados neste trabalho. A região sublinhada nos primers utilizados para síntese de dsRNA corresponde à cauda T7. Para os primers utilizados para quantificação relativa dos níveis de expressão dos microRNAs (miRNAs), encontramos somente o primer forward (F), pois como primer reverso (R) é utilizado um primer universal fornecido pelo kit utilizado neste experimento.

\begin{tabular}{|c|c|c|}
\hline $\begin{array}{l}\text { NOME DO } \\
\text { PRIMER }\end{array}$ & UTILIZAÇÃO & SEQUÊNCIA \\
\hline $\operatorname{crc} 5^{\prime}-\mathrm{F}$ & \multirow{8}{*}{ Sequenciamento } & 5' TCCAATCAGGACCAGGACAG 3' \\
\hline $\operatorname{crc} 5$ ' $-\mathrm{R}$ & & 5' AGATCATCCTACTCGTGCACAA 3' \\
\hline $\operatorname{crc} 3^{\prime}-\mathrm{F}$ & & 5' ССАСТСТТАСАСССССТСАА 3 ' \\
\hline $\operatorname{crc} 3$ ' - R & & 5' AATGAAGTACGCGTATGGCA 3' \\
\hline crc final - F & & 5' TGGTATGGTAGTTCCAGAGGAAA 3' \\
\hline crc final - $\mathrm{R}$ & & 5' GACCCTTAGCTTTAAATAAATCTCTCA 3' \\
\hline RfaBp $2-F$ & & 5' ATAGCCAACCAACCAACAGC 3' \\
\hline RfaBp 2 - R & & 5’ AGCTGCTTCTTTGGGATGAA 3' \\
\hline $\mathrm{crc}-\mathrm{F}$ & \multirow{18}{*}{$\begin{array}{c}\text { PCR - Real } \\
\text { Time }\end{array}$} & 5' GGAGATGTGGAAGCTTGTCA 3' \\
\hline $\operatorname{crc}-\mathrm{R}$ & & 5' ATGGTTGTACTGGTTGTAAAGT-3' \\
\hline RfaBP - F & & 5' TGCAAAGGCTGACGCTCAC-3' \\
\hline RfaBP - R & & 5' TGCCATCGCTGGTGACAGT 3' \\
\hline $\mathrm{USP}-\mathrm{RT} 2-\mathrm{F}$ & & 5' CGATATTCGACCGTGTCCTC 3' \\
\hline $\mathrm{USP}-\mathrm{RT} 2-\mathrm{R}$ & & 5' AGCAGGGTCACTTCCTGGAT 3' \\
\hline jhe-RT -F & & 5' CGTTACCTCCAGTTGGGAAA 3', \\
\hline jhe-RT -R & & 5' CAATCTTCGGCACCTTCAAT 3' \\
\hline EcR-A -F & & 5' CCAACAGCAACAACGGCTAC 3' \\
\hline EcR-B - F & & 5' ACAGTGTTGCCAACGGTCAC 3' \\
\hline MFE - F & & 5' GGAATCATTTCTTGCGGAGA 3' \\
\hline MFE - R & & 5' GTTATGCGCGCTATGGAAAT 3' \\
\hline EcR-A/B - R & & 5' - AAAGAGCCAGGCTGCGACAA - 3' \\
\hline RP-49 - F & & 5' CGTCATATGTTGCCAACTGGT - 3', \\
\hline RP-49 - R & & 5' TTGAGCACGTTCAACAATGG - 3' \\
\hline elFS-8 -F & & 5' TGAGTGTCTGCTATGGATTGCAA 3' \\
\hline elFS-8 - R & & 5' TCGCGGCTCGTGGTAAA 3' \\
\hline ame-miR-1-F & & 5' TGGAATGTAAAGAAGTATGGAG 3', \\
\hline
\end{tabular}




\begin{tabular}{|c|c|c|}
\hline $\begin{array}{l}\text { NOME DO } \\
\text { PRIMER }\end{array}$ & UTILIZAÇÃO & SEQUÊNCIA \\
\hline ame-miR-8-F & & 5' TAATACTGTCAGGTAAAGATGTC 3' \\
\hline ame-miR-12-F & & 5' TGAGTATTACATCAGGTACTGGT 3', \\
\hline ame-miR-34-F & & 5' TGGCAGTGTTGTTAGCTGGTTG 3' \\
\hline ame-miR-278-F & & 5' TCGGTGGGACTTTCGTCCGTTT 3' \\
\hline ame-miR-989-F & & 5' CGTGATGTGACGTAGTGGTTCT 3' \\
\hline ame-let-7-F & & 5' TGAGGTAGTAGGTTGTATAGT 3' \\
\hline ame-miR-263b-F & & 5'CTTGGCACTGGAAGAATTCAC 3 \\
\hline ame-miR-2796-F & & 5'GTAGGCCGGCGGAAACTACTTGC 3' \\
\hline $\mathrm{U} 6-\mathrm{F}$ & & 5'CAGGGGGCCATGCTAATCTTCT 3' \\
\hline dscrc-F & \multirow{10}{*}{$\begin{array}{c}\text { Síntese de } \\
\text { dsRNA }\end{array}$} & $5^{`}$ TAATACGACTCACTATAGGGCGAAGATCATCCTACTCGTGCACAA 3` \\
\hline dscrc-R & & 5' TAATACGACTCACTATAGGGCGATTGAGGGGGTGTAAGAGTGG 3' \\
\hline dsRfaBp-F & & 5’ TAATACGACTCACTATAGGGCGACACCGTTGATCCCAGAAATC $3^{\prime}$ \\
\hline dsRfaBp-R & & 5`TAATACGACTCACTATAGGGCGAACACCGCTTTGTTCAGAATG $3 `$ \\
\hline dsusp-F & & $5^{\prime}$ TAATACGACTCACTATAGGGCGAGCGAAGAGAAATCCTGCATC 3’ \\
\hline dsusp-R & & 5`TAATACGACTCACTATAGGGCGAGCCCTGAGCAGAAGTACCTG 3` \\
\hline dsJhe-F & & 5' TAATACGACTCACTATAGGGCGATAATCCATTCACACCGTTCG 3' \\
\hline dsJhe-R & & 5' TAATACGACTCACTATAGGGCGATTGCATTCTAGCTGCTTTTTCA 3' \\
\hline dsGFP-F & & 5' TAATACGACTCACTATAGGGCGAAGTGGAGAGGGTGAAGGTGA 3' \\
\hline dsGFP-R & & 5' TAATACGACTCACTATAGGGCGAGGTAAAAGGACAGGGCCATC 3', \\
\hline
\end{tabular}

\subsection{SEQUENCIAMENTO}

\subsubsection{MATERIAL BIOLÓGICO}

Operárias de Apis mellifera na fase pupal, foram coletados no Apiário do Departamento de Genética da Faculdade de Medicina de Ribeirão Preto, Universidade de São Paulo.

\subsubsection{EXTRAÇÃO DE RNA E SÍNTESE DE cDNA}

As extrações de RNA total foram feitas pelo método de TRIzol ${ }^{\circledR}$ Reagent (solução comercial de fenol e isotiocianato de guanidina para isolamento de RNA total, Cat. No. 15596-018, Invitrogen) 
utilizando indivíduos inteiros e seguindo-se o protocolo disponibilizado pelo fabricante. Após a extração, o RNA total foi quantificado por espectrofotometria e tratado com DNase. Posteriormente, o RNA total $(2,0 \mu \mathrm{g})$ foi utilizado para transcrição reversa (RT) usando-se SuperScript ${ }^{\circledR}$ II Reverse Transcriptase (Cat. No. 18064-022, Invitrogen) e Oligo $\mathrm{dT}_{12-18}$ (Cat. 18418-012, Invitrogen) como primer. Para utilização em reações de amplificação, o cDNA produzido foi diluído 1:10 em água estéril.

\subsubsection{AMPLIFICAÇÃO POR PCR}

As amplificações de fragmentos dos genes $c r c$ e RfaBp de A. mellifera foram feitas misturandose 2,0 $\mu \mathrm{l}$ de primer forward (específico para cada gene - Tabela 1) na concentração de $10 \mu \mathrm{M} ; 2,0 \mu \mathrm{l}$ de primer reverse (específico para cada gene - Tabela 1) na concentração de $10 \mu \mathrm{M} ; 2,5 \mu 1$ de cDNA diluído 1:10; 18,5 $\mu$ l água Mili-Q estéril; $25 \mu$ de MaterMix (2,5X) (Promega - cat. M7502). Para as amplificações foi utilizado o termociclador GeneAmp PCR System 9700, Applied Biosystems, assim programado: uma fase de desnaturação a $94^{\circ} \mathrm{C}$ por 2 minutos; em seguida $35-40$ ciclos a $94^{\circ} \mathrm{C}$ (desnaturação) por 30 segundos; $\mathrm{XX}^{\circ} \mathrm{C}\left({ }^{*}\right)$ por 30 segundos (fase de anelamento dos primers); e $72^{\circ} \mathrm{C}$ por 40 segundos (fase de extensão das novas fitas de DNA); e terminavam com 10 minutos a $72^{\circ} \mathrm{C}$ para finalizar as extensões. Os produtos da amplificação foram analisados em géis de agarose $1 \%$ e recuperados utilizando QIAquick ${ }^{\circledR}$ Gel Extraction Kit (250) (Cat. 28706, Lot. 127150235 - QIAGEN).

$\left.{ }^{*}\right)$ Esta temperatura varia de acordo com o primer utilizado, mas geralmente se aproxima dos $60^{\circ} \mathrm{C}$.

\subsubsection{LIGAÇÃO DO FRAGMENTO AO VETOR DE CLONAGEM}

O produto da PCR referente ao gene de interesse foi inserido no vetor plasmidial utilizando-se o Kit pGEM ${ }^{\circledR}$ - T Easy Vector System I (Promega - Cat. A1360, Lot. 206971). A reação de ligação foi feita com 3,0 $\mu$ l do produto da PCR adicionado de 5,0 $\mu$ l de $2 X$ Rapid Ligation Buffer (tampão de ligação), 1,0 $\mu \mathrm{l}$ de pGEM $^{\circledR}$ - T Easy Vector $(50 \mathrm{ng} / \mu \mathrm{l})$ e $1,0 \mu \mathrm{l}$ de T4 DNA ligase, seguida de incubação desta mistura à $4^{\circ} \mathrm{C}$, overnight . 


\subsubsection{TRANSFORMAÇÃO BACTERIANA E MINI-PREPARAÇÕES}

Para a transformação bacteriana foram utilizados 5,0 $\mu 1$ de solução plasmidial de cada gene, obtidos como no item anterior, contendo o fragmento de DNA clonado. A solução plasmidial foi adicionada às células competentes (Subcloning Efficiency ${ }^{\mathrm{TM}} \mathrm{DH} 5 \alpha^{\mathrm{TM}}$ chemically Competent $E$. coli Invitrogen cat.18265-017) e incubada em gelo por 30 minutos. Posteriormente, a suspensão foi submetida a choque térmico a $42^{\circ} \mathrm{C}$ por 30 segundos, seguido de resfriamento em gelo por 90 segundos, após os quais foram adicionados $250 \mu 1$ de meio de cultivo líquido (LB). Esta solução foi incubada a $37^{\circ} \mathrm{C}$, sob agitação de $160 \mathrm{rpm}$ por 1 hora, e posteriormente utilizada para semear uma placa de Petri com meio sólido contendo X-Gal, IPTG e ampicilina. Após o período de incubação de 16 horas a $37^{\circ} \mathrm{C}$ em estufa, as colônias que continham o inserto de interesse foram cultivadas em tubos plásticos estéreis contendo $5,0 \mathrm{ml}$ de $\mathrm{LB}$ com antibiótico (Ampicilina) a $37^{\circ} \mathrm{C}$, sob agitação de 160 rpm, por aproximadamente 16 horas. As células bacterianas resultantes foram submetidas à mini-

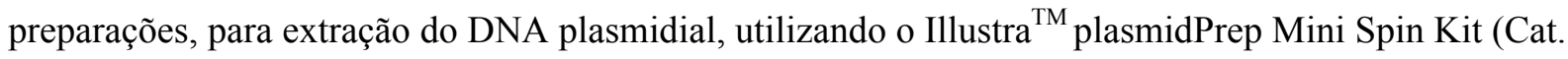
28-9042-70, Lot. 359092) seguindo-se as orientações do fabricante.

\subsubsection{DIGESTÃO DO DNA PLASMIDIAL}

Os produtos das mini-preparações foram digeridos com EcoR-I para verificar se o inserto estava presente na amostra. Para digestão utilizou-se 3,0 $\mu$ l de DNA plasmidial; 2,0 $\mu 1$ de solução tampão para EcoR I (Buffer 3); 14,5 $\mu$ l de água destilada estéril; 0,5 $\mu$ l de EcoR I, os quais foram misturados e incubados durante $60-90$ minutos a $37^{\circ} \mathrm{C}$. Posteriormente, os produtos de digestão foram separados em géis de agarose $1 \%$, corados com brometo de etídio e visualizados sob luz ultravioleta.

\subsubsection{SEQUENCIAMENTO GÊNICO E ANÁLISE DAS SEQUÊNCIAS}

O sequenciamento parcial de $c r c$ e $R f a B p$ foi feito pelo método Sanger et al. (1977) com DNA fita dupla marcado com fluorescência usando-se o kit BigDye Terminator v3 Cycle Sequencing Ready Reaction (Applied Biosystems). Para marcação do DNA foi feita reação de PCR e para sequenciamento foi usado o aparelho ABI 310 Genetic Analyzer (Applied Biosystems). As duas fitas 
(forward e reverse) foram sequenciadas usando-se os primers universais M13-F (5'- CGA CGT TGT AAA ACG ACG GCC AGT -3') e M13-R (5'- CAG GAA ACA GCT ATG AC -3').

As sequências de nucleotídeos obtidas foram submetidas ao programa Sequencher 4.7 - DNA Sequencig Software, para obtenção de um contig com os fragmentos resultantes. A sequência dos contigs (forward e reverse) foi traduzida em aminoácidos (http://www.justbio.com e http://www.expasy.ch/tools/dna.html) e analisada usando o programa BLAST, do banco de dados GenBank (http://www.ncbi.nlm.nih.gov/). Para obtenção da sequência genômica, correspondente ao fragmento amplificado, foram feitas análises comparativas consultando o banco de dados do genoma de A. mellifera (http://zulu.fmrp.usp.br/beelab). Com a sequência completa correspondente foram feitos alinhamentos com a sequência predita dos genes e com as sequências destes genes de outras espécies, utilizando o programa ClustalW (http://align.genome.jp/) (Para resultados veja Anexo 2).

\subsection{PARA OS ESTUDOS DE EXPRESSÃO DOS GENES}

\subsubsection{MATERIAL BIOLÓGICO}

Para a análise dos perfis de expressão dos genes de interesse, foram utilizadas rainhas e operárias nas fases de desenvolvimento embrionário, pós-embrionário e indivíduos adultos recém emergidos. As fases estudadas e sua descrição encontram-se na tabela 2. As abelhas, independente da fase, foram coletadas no Apiário do Departamento de Genética da Faculdade de Medicina de Ribeirão Preto, Universidade de São Paulo, sendo que as operárias foram obtidas através de postura controlada de 6-8 horas eram coletadas diretamente dos favos, e as rainhas, pela grande quantidade a ser utilizada, foram artificialmente produzidas. As fases de desenvolvimento foram identificadas de acordo com Michelette \& Soares(1993) e Rembold et al. (1980). 
Tabela 2: Características do desenvolvimento larval e pupal de rainhas e operárias de Apis mellifera africanizadas, incluindo o número de horas correspondente a cada uma das fases de desenvolvimento, contadas após a eclosão da larva. L1: $1^{\circ}$ estágio larval; L2: $2^{\circ}$ estágio larval; L3: $3^{\circ}$ estágio larval; L4: $4^{\circ}$ estágio larval; L5F: $5^{\circ}$ estágio larval, fase de alimentação (feeding) 1 (F1), 2(F2) e 3 (F3); L5S: $5^{\circ}$ estágio larval, fase de tecelagem do casulo 1 (S1), 2 (S2) e 3 (S3); PP: pré-pupa. Adaptado de Rembold et al. (1980), Michelette \& Soares (1993), Barchuk et al. (2004) e Nunes-Silva et al. (2006).

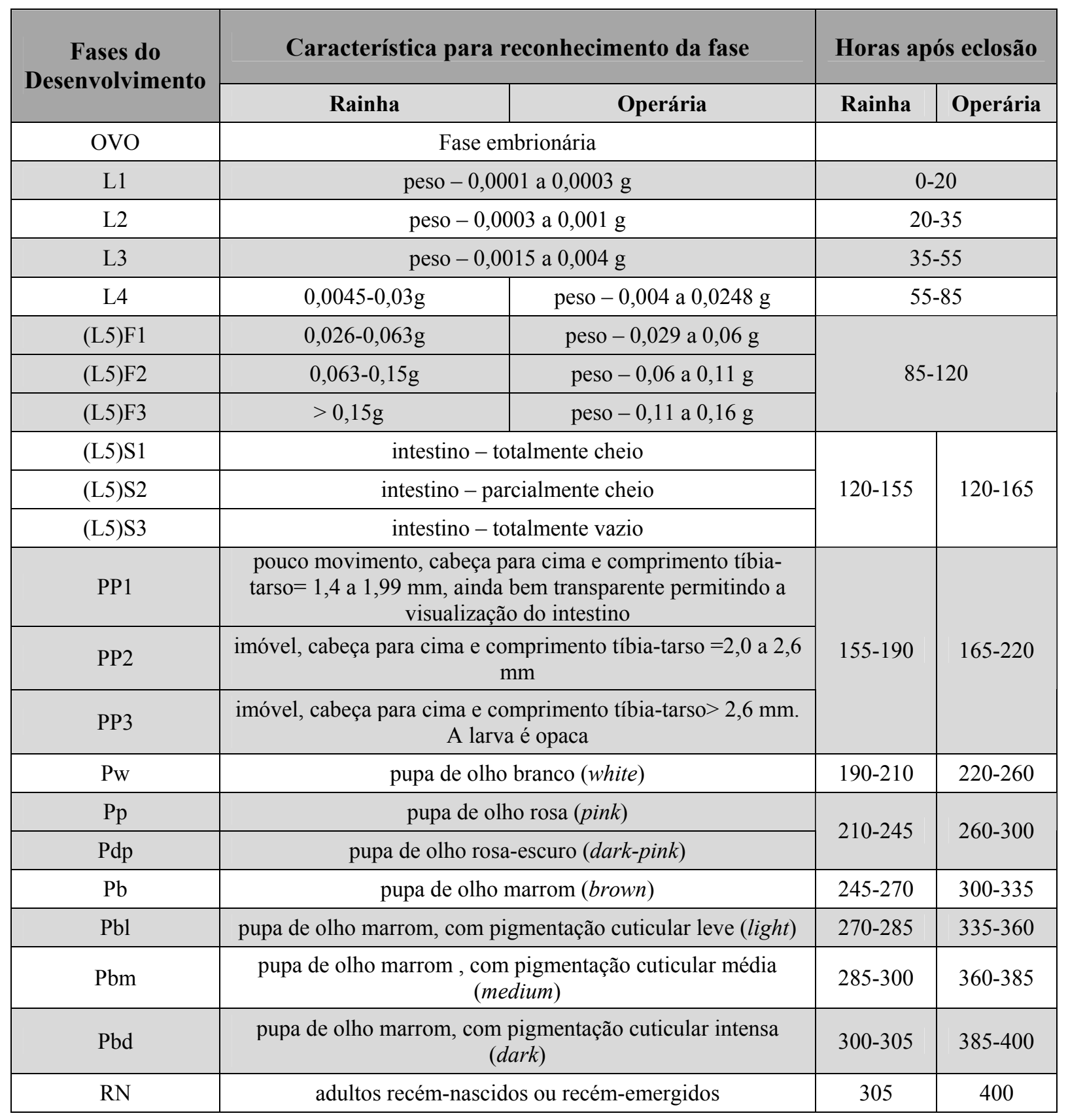

\subsubsection{ANÁLISE QUANTITATIVA (qPCR) OU PCR REAL-TIME}

Indivíduos inteiros nas fases acima citadas foram utilizados para extração de RNA e posterior síntese de cDNA como descrito no item 3.3.2. Para cada amostra utilizada para análise quantitativa por 
PCR em tempo real (Real-Time PCR) foram utilizadas três amostras de cDNA (tréplicas biológicas) e para cada uma delas foram feitas tréplicas experimentais, usando-se para detecção da amplificação SYBR ${ }^{\circledR}$ Green I Dye (Applied Biosystems) e ABI PRISM ${ }^{\circledR} 7500$ Sequence Detection System (SDS) (Applied Biosystems). As amostras foram preparadas utilizando-se $10 \mu 1$ do SYBR Green PCR Master Mix; $0,8 \mu \mathrm{l}$ de primer forward $10 \mu \mathrm{M}$ (Tabela 1); 0,8 4 l de primer reverse $10 \mu \mathrm{M}$ (Tabela 1); $1,0 \mu \mathrm{de}$ cDNA diluído 1:10 e 7,4 $\mu$ l de água estéril.-A quantificação dos transcritos de cada um dos genes de interesse foi calculada a partir da diferença dos valores de Ct (threshold PCR cycle) em relação aos transcritos do gene calibrador, rp-49 (ribosomal protein-49; Lourenço et al., 2008), de acordo com instruções do User Bulletin \#2 (Applied Biosystem) sendo que estes valores foram utilizados para a quantificação relativa da expressão. Os resultados destas quantificações foram utilizados para comparação estatística entre as os perfis de expressão nas castas.

\subsubsection{ANÁLISES ESTATÍSTICAS}

Para as análises da expressão diferencial em operárias e rainhas e em amostras tratadas com dsRNA e controle, os dados obtidos por Real-Time PCR foram analisados estatisticamente por meio do programa BioEstat (versão 4.0), utilizando o Teste Mann-Whitney $(\mathrm{p}<0,05)$.

\subsection{PARA OS MICROARRAYS}

\subsubsection{MATERIAL BIOLÓGICO E PROTOCOLO DOS EXPERIMENTOS}

Larvas de rainhas e operárias de A. mellifera em $4^{\circ}$ instar (L4), proveniente do apiário do Laboratório de Ecologia Química da Universidade da Pensilvânia nos Estados Unidos (Chemical Ecology Lab, The Pennsylvania State University, State College - PA, USA) foram utilizadas nos experimentos de expressão gênica em larga escala, microarrays. Esta fase foi escolhida, pois marca o início diferenciação das trajetórias de desenvolvimento seguidas por rainhas e operárias (Goewie, 1978). Rainhas e operárias foram obtidas e identificadas quanto à fase de desenvolvimento como descrito no item 3.4.1. Para cada uma das castas foram feitas oito amostras, sendo cada uma composta 
por um pool contendo 5 larvas, que foram hibridadas em 8 lâminas com dois corantes (design dyeswap) (Tabela 3) - sendo 4 hibridadas com uma reação contendo uma amostra de rainha marcada com Cy3 e uma de operária marcada com Cy5, e as outras 4 eram o contrário, as rainhas eram marcadas com Cy5 e as operárias com Cy3. Este tipo de delineamento de microarrays torna todas as amostras comparáveis.

Amostras biológicas referentes operárias nas fases de PP (pré-pupa) e Pbl (pupa de olho marrom com leve pigmentação no corpo) injetadas com um fragmento de RNA de $g f p$ em fita dupla (gene utilizado como controle em experimentos de RNAi) e controles (sem injeção) foram analisadas por microarrays. Para cada uma das duas fases de estudo foram feitas 8 amostras de pré-pupas (4 controles e 4 tratadas com dsGFP) e 8 amostras de pupas de olho marrom ( $\mathrm{Pbl}$ ) (4 controles e 4 tratadas com dsGFP), sendo que cada amostra continha apenas um indivíduo. Com estas amostras foram feitos 16 microarrays em design de loop (Figura 5). Este tipo de delineamento de microarrays é utilizado para que todas as amostras possam ser comparadas entre si (Para Resultados ver Anexo 3).

As lâminas de microarrays utilizadas (BeeOligo121106; http://www.biotech.uiuc.edu/centers/Keck/Functional_genomics/Honey\%20Bee\%20Oligo.htm) foram desenhadas pelo Dr. Gene E. Robinson (Universidade de Illinois, Urbana, EUA). Tais lâminas contêm 28.800 sequências de oligos de 60-69 nucleotídeos. Os spots presentes nas lâminas são referentes a praticamente todos os genes anotados na versão 4.0 do genoma de A. mellifera (sintetizados pela Invitrogen - http://www.ebi.ac.uk/aerep/result?queryFor=PhysicalArrayDesign\&aAccession=A-MEXP-755).

\subsubsection{SÍNTESE DE cDNA A PARTIR DO RNA NÃO-AMPLIFICADO}

Das amostras biológicas foi extraído o RNA como descrito no item 3.3.2, seguido de purificação com os kits RNeasy Mini Kit (50) (QIAGEN - cat. 74104) e RNase-Free DNase Set (50) (QIAGEN - cat. 79254). A síntese de cDNA foi feita utilizando o kit MessageAmpTM II aRNA (AmbionR . cat.AM1751). Para isto foi adicionado $\mathrm{X} \mu \mathrm{l}$ de RNA (X= volume contendo $750 \mathrm{ng}$, mas que não ultrapasse 5,0 $\mu 1)$ a $Y \mu 1$ de água livre de nuclease $(Y=$ volume para completar 5,0 $\mu 1)$ e a 1,0 $\mu 1$ de DT-T7. Esta mistura foi incubada a $70^{\circ} \mathrm{C}$ por 10 minutos e, em seguida, colocada no gelo. Foram adicionados mais $1,0 \mu 1$ de $10 \mathrm{X} 1^{\text {st }}$ strand buffer; $2,0 \mu 1 \mathrm{dNTP} 10 \mathrm{mM} ; 0,5 \mu 1$ RNase Inhibitor; $0,5 \mu 1$ 
MessageAmp/Arrayscript RT; incubou-se a $42^{\circ} \mathrm{C}$ por 2 horas. Após a incubação foram acrescentados: $32 \mu 1$ de $\mathrm{H} 2 \mathrm{O} ; 5,0 \mu \mathrm{l}$ de $10 \mathrm{X} 2^{\text {nd }}$ strand buffer; $2,0 \mu \mathrm{dNTP} 10 \mathrm{mM} ; 1,0 \mu 1$ de DNA polimerase e $0,5 \mu 1$ de $\mathrm{RNaseH}$, esta mistura foi incubada a $16^{\circ} \mathrm{C}$ por 2 horas. Após incubação, adicionou-se $250 \mu \mathrm{l}$ de cDNA Binding Buffer seguido de purificação em coluna que foi posteriormente lavada com $500 \mu 1$ de Wash buffer. O aRNA purificado foi eluído em $20 \mu \mathrm{l}$ de água pré-aquecida a $55^{\circ} \mathrm{C}$ e submetido a secagem no SpeedVac (Thermo Savant SC110A Speed Vac Plus) até um volume final de 8,0 $\mu 1$.

\subsubsection{AMPLIFICAÇÃO DO RNA COM T7}

Para amplificação do aRNA, obtido como descrito no passo anterior, foi utilizado o kit MEGAclear $^{\mathrm{TM}}$ (AmbionR - cat.AM1908). Aos 8,0 $\mu$ l de RNA obtidos como descrito no item anterior foram adicionados 8,0 $\mu 1$ de dNTPs (dATP, dGTP, dUTP, dCTP - 2,0 $\mu 1$ de cada), 2,0 $\mu 1$ de 10X T7 buffer, 2,0 $\mu 1$ da mistura de enzimas (enzyme mix), posteriormente a reação foi incubada a $37^{\circ} \mathrm{C}$ por 5 horas. Em seguida, foram acrescentados $80 \mu 1$ de $\mathrm{H}_{2} \mathrm{O} ; 350 \mu \mathrm{l}$ de aRNA binding buffer e $250 \mu \mathrm{l}$ de etanol $100 \%$. Este conteúdo foi purificado em coluna e submetido a lavagens com $600 \mu 1$ de Wash buffer seguida de $650 \mu \mathrm{l}$ de etanol $80 \%$. O aRNA presente na membrana da coluna foi eluído em $100 \mu$ lde água estéril pré-aquecida a $55^{\circ} \mathrm{C}$ e sua concentração foi determinada no NanoDrop 1000 (Thermo Scientific).

\subsubsection{MARCAÇÃO POR ULS ${ }^{\mathrm{TM}}$ (UNIVERSAL LINKAGE SYSTEM), PURIFICAÇÃO E FRAGMENTAÇÃO DO aRNA}

A marcação das amostras foi feita utilizando-se o kit $\mathrm{ULS}^{\mathrm{TM}}$ aRNA Labeling (com Cy3 e Cy5 Kreatech - cat.EA-006). A partir deste ponto, todos os procedimentos foram realizados em ambiente com pouca iluminação para evitar degradação dos fluoróforos cianina 3 (Cy3 - cyanine) e cianina 5 (Cy5 - cyanine). Para cada reação foram adicionados: 4,0 $\mu \mathrm{g}$ de aRNA (com um volume máximo de $32 \mu 1$ ); 4,0 $\mu 1$ de Cy3- ou Cy5-ULS; 4,0 $\mu 1$ de 10x labeling solution (solução de marcação) e água livre de nuclease suficiente para completar $40 \mu \mathrm{l}$, que foram incubados a $85^{\circ} \mathrm{C}$ por 30 minutos, após o período de incubação, a concentração de cada uma das soluções foi determinada utilizando-se o aparelho Nanodrop. Em seguida, os aRNAs marcados foram misturados dois a dois: um marcado com Cy3 correspondente a uma das castas e outro marcado com Cy5 correspondente a outra casta (rainhas 
versus operarias em L4). Esta mistura de aRNAs marcados foi purificada utilizando-se as colunas KREApure do kit KREApure purification columns (Kreatech - cat. KP-050) em seguida foram concentradas no SpeedVac para um volume final de 9,0 $\mu$ l. Utilizando-se o kit RNA Fragmentation Reagents (AmbionR - cat. AM8740) os 9,0 $\mu 1$ de aRNA marcado foi fragmentado acrescentando-se $1,0 \mu 1$ de 10X fragmentation buffer e incubando-se a $70^{\circ} \mathrm{C}$ por 15 minutos e acrescentando posteriormente $1,0 \mu 1$ de Solução Stop (Stop Solution).

\subsubsection{PREPARAÇÃO, PRÉ-HIBRIDAÇÃO E HIBRIDAÇÃO DAS LÂMINAS DE MICROARRAYS}

Primeiramente as lâminas de microarrays foram limpas com ar comprimido para eliminar qualquer tipo de poeira existente. Posteriormente, vapor d'água era utilizado para umedecer as lâminas levemente que em seguida eram secas sobre o termobloco pré-aquecido. As lâminas secas foram tratadas com luz UV (ultravioleta) durante 5 minutos. Antes da pré-hibridação, as lâminas foram submersas em uma cuba contendo SDS $0,2 \%$, pré-aquecido a $55^{\circ} \mathrm{C}$, e imediatamente submetidas a vigorosa agitação manual por 2 minutos, para prevenir ou minimizar a formação de "cometas". Em seguida as lâminas foram lavadas em água Mili-Q, em dois banhos de 30 segundos sob agitação manual e um terceiro banho de 15 segundos e secas por centrifugação (500 rpm por 3 minutos). Estas lâminas foram incubadas em solução de pré-hibridação a $42^{\circ} \mathrm{C}$ por 90 minutos, em seguida lavadas em três banhos rápidos com água Mili-Q e secas por centrifugação (500 rpm por 3 minutos).

O tampão de hibridação ${ }^{1}$ foi utilizado na preparação da solução de hibridação ${ }^{2}$ que foi incubada a $80^{\circ} \mathrm{C}$ por 10 minutos, após os quais era despejada na lâmina de microarrays, já coberta por uma lamínula própria que continha um orifício por onde a solução era despejada. Em seguida, as lâminas foram submetidas à incubação no MAUI Mixer A4 Hybridization Chambers (Cat N ${ }^{\circ}$. 02-A008-25 BioMicro Systems, Inc.) por 15-17 horas, sob temperatura $\left(42^{\circ} \mathrm{C}\right)$ e umidade controladas.

\footnotetext{
* Solução de Pré-Hibridação: 12,5 ml de 20X SSC + 0,5 ml de SDS 10\% + 0,5 g de I-Block (Applied Biosystems. cat. $\mathrm{T} 2015)+37 \mathrm{ml}$ de água livre de nuclease.

${ }^{1}$ Tampão de hibridação: 5,0 ml de formamida (Promega . cat. H5051) + 5,0 ml de SSC 20X (Promega - cat. V4261) + 200 $\mu 1$ de SDS 10\% (Promega . cat.V6551).

${ }^{2}$ Solução de Hibridação: $27,5 \mu \mathrm{l}$ de formamide hyb buffer $2 \mathrm{X}+11 \mu \mathrm{l}$ da solução dos aRNA marcados (um com Cy3 e o outro com Cy5) $+13,75 \mu 1$ de KREAblock (ULS. aRNA Labeling Kit -with Cy3 and Cy5)+ 2,75 $\mu 1$ de água livre de nuclease.
} 


\subsubsection{LAVAGENS PÓS-HIBRIDAÇÃO}

Após 15-17 horas de incubação as lamínulas foram removidas das lâminas de microarrays por imersão em solução de lavagem 1 (100 ml de SSC 20X + 20 ml de SDS 10\% + 880 ml de água MiliQ) a $42^{\circ} \mathrm{C}$ e descolamento manual. As lâminas foram submetidas a lavagens sequenciais na solução 1 (a $42^{\circ} \mathrm{C}$ ), solução $2(100 \mathrm{ml}$ de SSC $20 \mathrm{X}+900 \mathrm{ml}$ de água Mili-Q) e na solução 3 (10 ml de SSC 20X + $990 \mathrm{ml}$ de água Mili-Q) na ausência de iluminação, sob agitação por 10 minutos cada uma e secas por centrifugação (500 rpm por 3 minutos). Os resultados foram lidos pelo GenePix 4000B Microarray Scanner.

\subsubsection{ANÁLISES DOS RESULTADOS DOS MICROARRAYS}

Os arquivos de imagem gerados foram analisados inicialmente pelo programa do próprio equipamento, GenePix 4000B, para o cálculo das medianas (F635 Median - B635 e F532 Median -B532), que correspondem aos valores de expressão encontrados para cada spot. Estes valores eram organizados em uma planilha em formato para análise pelo programa JMP (http://www.jmp.com/uk/software/genomics/index.shtml). Todos os spots com valores menores que a mediana calculada para as amostras sem oligos (chamadas de brancos), que são designadas como ruído de fundo da preparação foram removidos da análise. Transcritos (spots) com menos de 6 medidas, entre as 8 possíveis também foram removidos da análise. Os dados que passaram por esse critério foram transformados em valores logarítmicos e analisados utilizando ANOVA modelo-misto como abordagem implementada no software SAS (SASR 9.2 Software - http://www.sas.com/software/sas9/) (Wolfinger et al. 2001, Ayroles \& Gibson, 2006; Kocher et al., 2008). Os valores de P (P-values) foram corrigidos utilizando-se múltiplos testes para o ajuste por taxa de descoberta de falsos positivos (FDR - false discovery rate). O valor limite de FDR utilizado foi de 0.01 (FDR01), supondo que apenas 1\% dos transcritos significativos deve ser constituído por falsos positivos.

\subsubsection{ANÁLISE DOS GENES COM EXPRESSÃO DIFERENCIAL ENTRE AS CASTAS}

Ao final das análises descritas acima e usando FDR01 obtivemos uma lista de genes diferencialmente expressos que foi utilizada para as análises de Gene Ontology (GO). Estas análises foram 
feitas utilizando a ferramenta de anotação gênica funcional DAVID (Dennis et al., 2003 -

http://david.abcc.ncifcrf.gov/gene2gene.jsp). Esta análise resultou em uma lista de genes diferencialmente expressos e dentre estes foram escolhidos os "top ten" preferencialmente expressos em operárias de acordo com os valores ESTIMATE (que compara os níveis de expressão de uma casta versus a outra).

Tabela 3: Desenho experimental de microarrays para comparação de rainhas e operárias em fase L4 em relação à expressão gênica diferencial. Array: número de arrays feitos; Cy3: amostras marcadas com cianina 3; Cy5: amostras marcadas com cianina 5; W:operárias; Q: rainhas. No array 1 a amostra W2, marcada com Cy3 (W2) foi hibridada juntamente com a amostra marcada com Cy5 (Q2) e assim por diante até o array 8.

\begin{tabular}{|c|c|c|}
\hline Array & Cy3 & Cy5 \\
\hline 1 & W2 & Q2 \\
\hline 2 & W3 & Q5 \\
\hline 3 & W4 & Q7 \\
\hline 4 & W5 & Q8 \\
\hline 5 & Q9 & W6 \\
\hline 6 & Q10 & W7 \\
\hline 7 & Q11 & W8 \\
\hline 8 & Q1 & W1 \\
\hline
\end{tabular}

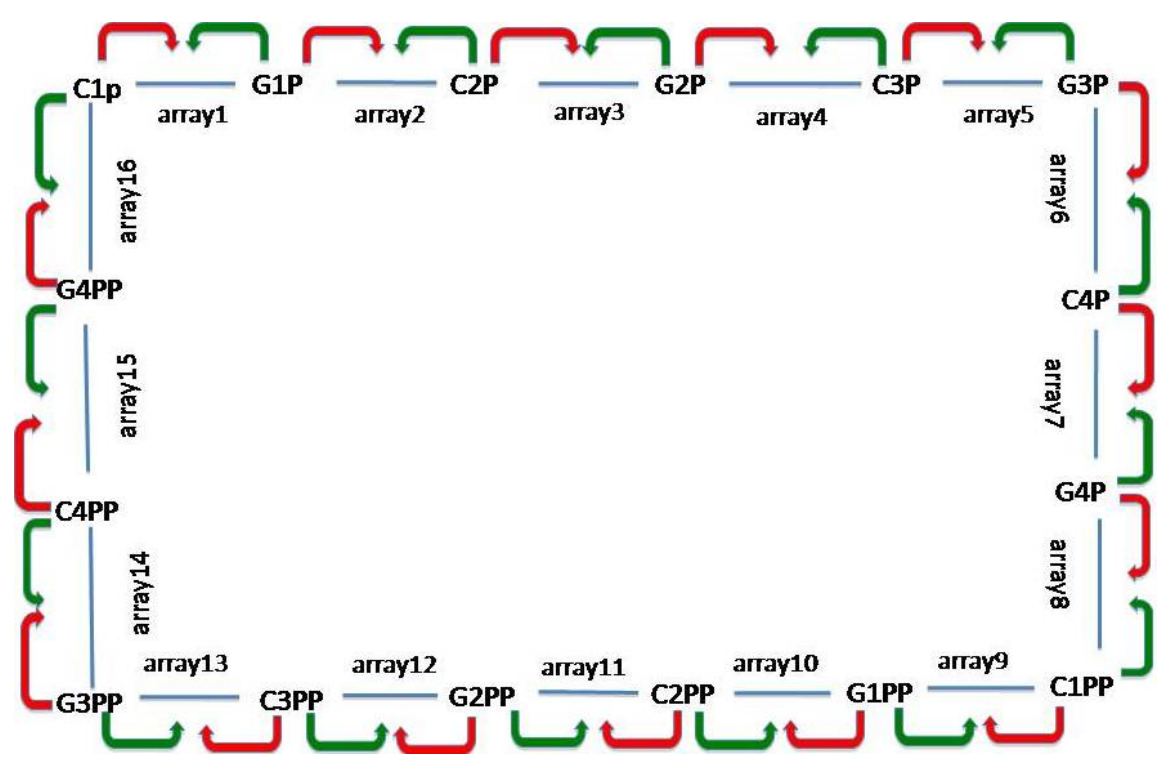

Figura 5: Diagrama do experimento de microarray para a análise dos efeitos de dsGFP usado como controle nos experimentos de silenciamento gênico em A. mellifera. Setas vermelhas: amostras marcadas com cianina 5 (Cy5); Setas verdes: amostras marcadas com cianina 3 (Cy3); C1-C4: amostra controle que não receberam RNA dupla-fita 1-4; G1-4: amostras que receberam RNA dupla-fita para o gene $g f p$; PP: amostras coletadas na fase de desenvolvimento pré-pupa; P: amostras coletadas na fase de desenvolvimento Pbl (pupa de olho marrom, com leve pigmentação corporal). 


\subsection{PARA OS ESTUDOS DE SILENCIAMENTO UTILIZANDO INTERFERÊNCIA POR RNA (RNAi)}

\subsubsection{MATERIAL BIOLÓGICO}

Para o silenciamento utilizando o método de interferência por RNA (RNAi) foram utilizadas pupas para a síntese do RNA de fita dupla (dsRNA) para os genes alvos. A síntese do dsRNA para o gene utilizado como controle, $g f p$, foi feita a partir de clones que continham uma sequência deste gene, gentilmente cedidos pela Profa. Dra. Maria Helena de Souza Goldman. Para o tratamento com o dsRNA, independente do gene alvo ou controle, eram utilizadas larvas em $2^{\circ}$ estágio (L2) obtidas e identificadas de acordo com o descrito no item 3.4.1. As abelhas utilizadas nesta etapa foram obtidas do Apiário do Laboratório de Ecologia Química da Universidade da Pensilvânia nos Estados Unidos (Chemical Ecology Lab, The Pennsylvania State University, State College - PA, USA) no caso dos experimentos realizados com o gene usp e do Apiário do Departamento de Genética da Faculdade de Medicina de Ribeirão Preto, Universidade de São Paulo, para os experimentos feitos com os demais genes.

\subsubsection{PRIMERS}

Foram desenhados primers específicos para cada gene a ser silenciado, $c r c, u s p, R f a B p$ e $j h e$ (Tabela 1) e para o gene utilizado como controle, o $g f p$, de acordo com o que foi descrito no item 3.2. Dois tipos de primers eram desenhados para cada gene, um deles utilizado na síntese de dsRNA e o outro destinado a análise da eficiência do silenciamento por PCR quantitativa (qPCR) ou Real-Time. À sequência primers utilizados na síntese de dsRNA era adicionada a cauda T7 (5'TAATACGACTCACTATAGGGCGA - 3’) necessária para o sucesso na utilização no kit de síntese. Os demais primers eram comuns e desenhados em uma região diferente dos anteriores, para assegurar que não amplificariam os fragmentos utilizados no tratamento de interferência por RNA. 


\subsubsection{AMPLIFICAÇÃO POR PCR}

Anterior à síntese de dsRNA propriamente dita, foram feitas PCRs com volume total de $50 \mu 1$ misturando-se 2,0 $\mu 1$ de primer forward (específico para cada gene- Tabela 1) na concentração de 10 $\mu \mathrm{M} ; 2,0 \mu 1$ de primer reverse (específico para cada gene - Tabela 1) na concentração de $10 \mu \mathrm{M} ; 2,5 \mu 1$ de cDNA; 18,5 $\mu 1$ água Mili-Q estéril; $25 \mu 1$ de MaterMix (2,5X) (Promega - cat. M7502). As amplificações, análise e recuperação dos produtos amplificados se seguiram como no item 3.3.3. Também de acordo com o que já foi descritos em itens anteriores, foi feita ligação dos fragmentos aos vetores de clonagem (item 3.3.4), transformação bacteriana e mini-preparações (item 3.3.5), digestão do DNA plasmidial (item 3.3.6) e visualização dos fragmentos utilizando géis de agarose.

\subsubsection{SUPER PCR}

Para cada um dos genes de interesse, foi feita uma "Super-PCR" com oito tubos para cada amostra com um volume de $40 \mu \mathrm{l}$ cada um, na seguinte proporção: 2,0 $\mu \mathrm{l}$ de primer forward (específico para cada gene - Tabela 1) na concentração de $10 \mu \mathrm{M} ; 2,0 \mu 1$ de primer reverse (específico para cada gene - Tabela 1) na concentração de $10 \mu \mathrm{M} ; 2,0 \mu \mathrm{l}$ de cDNA; 9,0 $\mu$ l água Mili-Q estéril; $25 \mu 1$ de Epperndorf MaterMix (2,5X), em seguida procedeu-se a amplificação dos genes de interesse por PCR, utilizando o programa como descrito no item 3.3.3. Os produtos de cada uma das oito amostras foram colocados em um único tubo, totalizando um volume final de $320 \mu \mathrm{l}$. Deste total, $300 \mu \mathrm{l}$ foram purificados (QIAquick PCR Purification kit [250] - QIAGEN - cat.28106) e $20 \mu \mathrm{l}$ foram armazenado a $-20^{\circ} \mathrm{C}$ e utilizados em géis de agarose para verificação em passos seguintes, junto com cada produto produzido segundo estes passos.

\subsubsection{SÍNTESE DO RNA DE FITA DUPLA (dsRNA)}

O dsRNA foi sintetizado para cada gene de interesse ( $c r c, R f a B p$, usp e jhe) e para o controle ( $g f p$ ) utilizando o kit RiboMax ${ }^{\mathrm{TM}}$ Large Scale RNA Production System . T7 (cat.1300 - Promega). Foram utilizados 9,0 $\mu \mathrm{g}$ de DNA, purificado da "Super-PCR" descrita anteriormente, e seguindo-se as instruções do fabricante do kit. Adicionou-se, nesta ordem", $20 \mu 1$ de T7 transcription 5X buffer, $30 \mu 1$ de rNTPs $(25 \mathrm{mM}$ cada - misturar 7,5 $\mu \mathrm{l}$ de cada um a $100 \mathrm{mM}$ - U,A,C e G - para que estejam a 25

\footnotetext{
* Nas especificações do fabricante está destacado que a ordem em que os reagentes são adicionados é muito importante para sucesso na síntese.
} 
mM no final), $40 \mu 1$ de DNA molde $(9,0 \mu \mathrm{g}$ DNA obtido através da Super-PCR + água para completar $40 \mu 1$, quando necessário) e $10 \mu 1$ da mistura de enzimas. Posteriormente, a reação foi incubada a $37^{\circ} \mathrm{C}$ por 8 horas. A integridade, assim como a presença de apenas uma banda correspondente ao fragmento de interesse, foi novamente verificada através de gel de agarose.

\subsubsection{PURIFICAÇÃO DO dsRNA UTILIZANDO TRIzol ${ }^{\circledR}$}

Aos $100 \mu 1$ de dsRNA obtidos foram adicionados a $150 \mu l$ de água livre de nuclease e $750 \mu 1$ de TRIzol $^{\circledR}$. Essa mistura era mantida em temperatura ambiente por 5 minutos e então se seguia o protocolo de extração com TRIzol ${ }^{\circledR}$ como no item 3.3.2. Ao final da extração, o dsRNA era ressuspendido em $30 \mu 1$ de água livre de nuclease, mantido a $50^{\circ} \mathrm{C}$ no termobloco por 5 minutos e renaturado a $98^{\circ} \mathrm{C}$ por 5 minutos seguidos de incubação à temperatura ambiente por 30 minutos. Uma alíquota de $1,0 \mu 1$ deste dsRNA recém sintetizado era adicionado a 9,0 $\mu 1$ de água livre de nuclease para quantificação e para última verificação em gel de agarose, no qual nenhuma banda menor que o fragmento de interesse deve ser visualizada. $\mathrm{O}$ restante da amostra foi aliquotado e armazenado a $-80^{\circ} \mathrm{C}$ até sua utilização.

\subsubsection{TRATAMENTO COM dsRNA}

As larvas de segundo estágio (L2) foram tratadas com dsRNA. O dsRNA era aplicado no alimento larval diretamente no favo (Figura 6), que posteriormente era devolvido à colônia e mantido nela até a coleta dos indivíduos na fase de interesse (Nunes \& Simões, 2009). Para este experimento foi aplicado $1,0 \mu 1$ de dsRNA na concentração de $5,0 \mu \mathrm{g} / \mu 1$, para os genes $u s p$ e $j h e$ e $1,0 \mu \mathrm{g} / \mu 1$ para os genes $c r c$ e $R f a B p$. Para estes dois últimos, a quantidade administrada de dsRNA foi menor, pois com quantidades maiores os indivíduos não sobreviviam ou eram retirados da colônia. Inicialmente o dsRNA para o gene green fluorescent protein $(g f p)$, era utilizado como controle por não ter um correspondente no genoma de $A$. mellifera, e portanto, esperava-se que não causasse efeito na expressão gênica desta espécie. Contrariamente a isto, o que observamos ao longo dos experimentos de RNAi utilizando este controle, foi um efeito deste na expressão dos genes alvo (Ver Anexo 4 para resultados), o que foi corroborado com outros procedimentos experimentais (Anexo 3A), então apenas o controle para o qual nenhum tipo de dsRNA fio administrado, foi utilizado para as análises finais. 


\subsubsection{1 esterase do hormônio juvenil -jhe}

Para este gene 12 indivíduos foram tratados com o dsRNA (dsjhe) e 12 indivíduos que não receberam dsRNA foram utilizados como controle. Foram obtidas 4 amostras correspondentes ao tratamento e 4 amostras correspondentes ao controle, cada uma delas formada por um pool de 3 indivíduos. Os indivíduos foram coletados em S1 ( $5^{\circ}$ instar larval, fase de spinning 1$)$, fase em que $j h e$ apresentava altos níveis de expressão, de acordo com perfil parcial obtido anteriormente.

\subsubsection{2 ultraspiracle -usp}

Para o silenciamento de usp 3-4 indivíduos foram tratados com o dsRNA (dsusp) e 3-4 indivíduos que não receberam dsRNA foram utilizados como controle. A partir destes indivíduos foram obtidas as amostras para cada grupo. Os indivíduos foram coletados em duas diferentes fases do desenvolvimento, 3 indivíduos no início da fase Pré-pupal (PP) e 4 indivíduos no final do estágio Pupal ( $\mathrm{Pbl}$ - pupa de olho marrom com leve pigmentação no corpo). Portanto são no total, 14 indivíduos, 6 em PP e 8 em Pbl. No período pré-pupal os níveis de expressão de usp estão elevados, de acordo com perfil de expressão obtido, e por isto foi escolhido, enquanto que indivíduos em Pbl, foram coletados para sabermos a duração do efeito do RNAi, assim como a influência no desenvolvimento de abelhas.

\subsubsection{3 cryptocephal - crc e retinoid- and fatty acid-binding protein - RfaBp}

Foram tratados 8 indivíduos para $c r c$ e 10 indivíduos para $R f a B p$ com o dsRNA correspondente (dscrc e dsRfaBp). Além disto, indivíduos que não receberam em sua dieta nenhum tipo de tratamento, foram utilizados como controle. A fase de desenvolvimento em que ambos foram coletados foi L5S1 ( $5^{\circ}$ instar larval $-1^{\circ}$ fase de spinning ou tecelagem do casulo). Esta fase foi escolhida, pois, os níveis de expressão do gene eram relativamente altos, segundo o perfil determinado anteriormente.

\subsubsection{PARA VERIFICAÇÃO DA EFICIÊNCIA DO SILENCIAMENTO}

O material coletado teve o RNA total extraído e posterior síntese de cDNA se seguia como no item 3.3.2). Este cDNA era utilizado em qPCR (item 3.4.2) utilizando primers para os genes alvo e 
para os genes utilizados para normalização (ribosomal-protein 49 - rp-49 e elongation-factor $S-8$ elFS-8 - Tabela 1) desenhados como descrito no item 3.2. Os resultados eram analisados para determinar a eficiência do silenciamento do gene de interesse por interferência de RNA através da quantificação dos transcritos realizadas como descrita acima (item 3.4.2). Os resultados foram analisados estatisticamente utilizando Teste Mann-Whitney $(\mathrm{p}<0,05)$, programa BioEstat versão 4.0.

Além da verificação do próprio gene em relação ao seu silenciamento, analisamos também a influencia do silenciamento destes genes sobre a expressão dos demais genes aqui estudados e ainda acrescentamos o gene $E c R$ (receptor de ecdisona), com suas variantes A e B, nas análise, por ser este o parceiro heterodimérico de usp no receptor de ecdisona, podendo então ter seus níveis de transcrito modificados pelos níveis de seu parceiro e também por genes que exercem seu efeito sobre ele. Tais análises foram feitas da mesma maneira que aquela feita para o gene, utilizando quantificação dos transcritos por qPCR e análises como descrito acima.

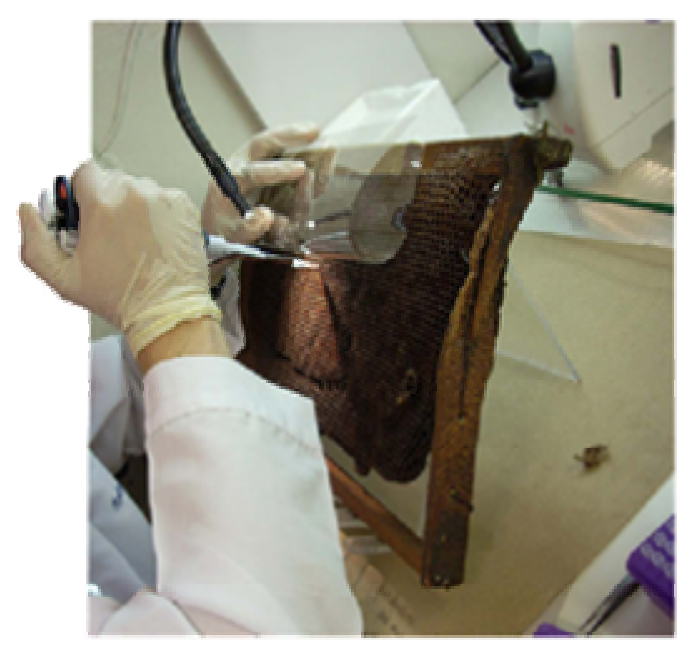

Figura 6: Demonstração do procedimento utilizado para administrar RNA de fita dupla (dsRNA) na dieta natural de larvas no segundo estágio de abelhas Apis mellifera em experimentos de interferência por RNA (RNAi). (Nunes \& Simões, 2009). 


\subsection{IDENTIFICAÇÃO DOS miRNAS CANDIDATOS A REGULADORES DO GENE DA esterase do hormônio juvenil (jhe)}

\subsubsection{PREDIÇÃO DOS microRNAs REGULADORES DO GENE DA esterase do hormônio juvenil (jhe)}

Para identificar os miRNAs candidatos a reguladores do gene jhe, a região 3' não-traduzida do gene $j h e$ foi submetida a uma busca por sítios de ligação para os miRNAs de $A$. mellifera recuperados da versão 18 do miRBase (www.mirbase.org/). Essa predição foi realizada pelo programa RNAhybrid (Rehmsmeier et al. 2004), considerando pareamento na região da seed (2-7 nt), valores de energia livre inferiores a $-15 \mathrm{kcal} / \mathrm{mol}$ e $p$-value menor que 0.05 . Este gene foi escolhido pelo papel que desempenha na degradação do HJ, um dos principais fatores envolvidos na determinação de castas.

\subsubsection{VALIDAÇÃO DA PREDIÇÃO DOS microRNAs REGULADORES DO GENE jhe}

Para avaliar os níveis de expressão relativa dos miRNAs sugeridos como reguladores de jhe, dois conjuntos de amostras foram utilizados: 1) RNA extraído de larvas tratadas com dsjhe e de larvas controle; 2) RNA de rainhas e operárias nas fases L5F3 (fase em que as operárias apresentam maior nível de transcritos de jhe), L5S2 (fase em que rainhas apresentam maior nível de transcritos de jhe) e $\mathrm{Pb}$ (fase em que ambas operárias e rainhas apresentam níveis basais de transcritos de $j h e$ ). Do total de miRNAs sugeridos como reguladores de $j h e$, elegemos os miRNAs let-7, $m i R-1, m i R-8, m i R-12, m i R-$ 34, $m i R-278$ e miR-989, miR-263b para validação por PCR em tempo real. Além destes, o miR-2796 foi incluído na validação por apresentar expressão altamente diferencial entre as castas, com expressão preferencial em rainhas (comunicação pessoal de Zayed, A.). A validação dos miRNAs candidatos a reguladores do gene $j$ he foi realizada com base na função canônica dos miRNAs de reduzir os níveis dos transcritos-alvos através do pareamento da seed com a região 3' não-traduzida do gene-alvo. Assim, foram considerados os valores de expressão do gene $j$ he e dos miRNAs eleitos nos pontos do desenvolvidos escolhidos de operárias e rainhas. Calculou-se o coeficiente de Pearson (r) (informações em Bieguelman, 2002) entre os valores de Ct do gene jhe e dos miRNAs. Os pares de miRNA:genealvo que apresentaram $-1.0<r<-0.8$ foram apontados como forte candidatos por possuírem perfis antagônicos de expressão. 


\subsubsection{SÍNTESE DE cDNA A PARTIR DE miRNAs E QUANTIFICAÇ̃̃O POR PCR} REAL-TIME

O cDNA utilizado para verificação dos níveis de transcritos dos miRNAs selecionados para validação foi sintetizado a partir do RNA total (obtido conforme descrito na seção 3.6.7.4) usando NCode $^{\mathrm{TM}}$ miRNA First-Strand cDNA Synthesis qRT-PCR Kit (Invitrogen ${ }^{\mathrm{TM}}$ - cat. MIRC-50), seguindo-se as especificações do fabricante. Foram utilizados dois primers na síntese do cDNA: um primer reverse universal (fornecido pelo $\mathrm{NCode}^{\mathrm{TM}}$ miRNA First-Strand cDNA Synthesis qRT-PCR Kit) e o outro foward específico para cada miRNA. Para obter a sequência do primer específico, as sequências dos miRNAs maduros foram recuperadas a partir do miRBase e as mesmas tiveram as bases uracila (U) substituídas por timina (T) (Tabela 1). As quantidades de cada reagente utilizadas em cada reação foram: $10 \mu \mathrm{l}$ do SYBR Green PCR Master Mix; 0,4 $\mu$ l de primer específico10 $\mu \mathrm{M}$ (Tabela 1); 0,4 $\mu \mathrm{l}$ de primer universal $10 \mu \mathrm{M} ; 2,0 \mu \mathrm{l}$ de cDNA (diluído 1:10); 7,2 $\mu 1$ de água Mili-Q estéril. A quantificação dos transcritos dos miRNAs foi normalizada com a expressão do gene codificador do pequeno RNA nuclear U6. A quantificação relativa dos transcritos foi calculada utilizando o método comparativo Ct (Applied Biosystems, User bulletin \# 2). Também foram realizadas análises da curva de dissociação para testar a especificidade e a qualidade das reações de PCR em tempo real. Os níveis de expressão dos miRNAs em rainhas e operárias, em cada fase do desenvolvimento estudada (Anexo 6), assim como aqueles encontrados para tratamento com dsjhe e controle, foram analisados estatisticamente com ajuda do programa BioEstat (4.0), utilizando o teste Mann-Withney $(\mathrm{p}<0,05)$.

\subsection{IDENTIFICAÇÃO DOS MIRNAS AFETADOS PELO SILENCIAMENTO DO GENE CODIFICADOR DA esterase do hormônio juvenil - jhe}

\subsubsection{SEQUENCIAMENTO EM LARGA ESCALA DE PEQUENOS RNAs}

Com a finalidade de identificar os miRNAs afetados pelo silenciamento do gene $j$ he, amostras de RNA coletadas no experimento de silenciamento do gene jhe (conforme procedimento descrito no item 3.6.7.4) foram submetidas a um sequenciamento em larga escala. Três amostras de RNA extraído 
de larvas tratadas com dsjhe e três amostras de RNA obtidas de larvas controle foram enviadas a facility da Universidade da Carolina do Norte (High-Throughput Sequencing Facility, na cidade de Chapel Hill, EUA), onde foram preparadas e sequenciadas na plataforma Illumina (Genome Analyzer II, Life Sciences). O responsável pelo sequenciamento isolou moléculas de RNAs menores que 200 nucleotídeos, fração de RNA que contém as moléculas de miRNAs, seguindo o protocolo do fabricante (TruSeq ${ }^{\mathrm{TM}}$ Small RNA Sample Preparation Guide, Illumina, Life Sciences).

\subsubsection{ANÁLISE DAS BIBLIOTECAS GERADAS PELO SEQUENCIAMENTO EM LARGA}

\section{ESCALA}

Os arquivos contendo as sequências curtas (reads) geradas pelo sequenciamento foram enviadas ao servidor do Laboratório de Biologia do Desenvolvimento de Abelhas onde foram processados em colaboração com a doutoranda Flávia Cristina de Paula Freitas. A ferramenta Cutadapt (http://code.google.com/p/cutadapt) foi utilizada para remover a sequência dos adaptadores (utilizados no preparo das bibliotecas) e para filtrar reads com qualidade Phred maior que 20 (que reflete um acerto de 99\% no reconhecimento das bases ou base calling, (Ewing \& Green, 1998; Ewing et al., 1998). Em seguida, utilizando script desenvolvido em linguagem Python (www.python.org), foi calculada a distribuição das reads por comprimento (nt), com a finalidade de caracterizar as bibliotecas.

Após a remoção dos adaptadores, as reads foram mapeadas contra um banco de sequências expressas composto por sequências de rRNA (RNA ribossômico), tRNA (RNA transportador), miRNAs (microRNAs), outros RNAs não-codificadores, RNAs codificadores de proteínas e RNAs de patógenos de abelhas $A$. mellifera (Tabela 4). O mapeamento foi realizado pelo programa BWA (Burrows-Wheeler Aligner, Li \& Durbin, 2009). O programa BWA gera arquivos no formato SAM que apresentam diversas informações sobre o mapeamento das reads. Scripts em linguagem Python foram desenvolvidos para analisar os arquivos SAM e identificar as entidades genéticas expressas nas bibliotecas. Para as análises seguintes, as reads que mapearam nas sequências de miRNAs de abelhas foram contabilizadas e essa contagem normalizada pelo número de reads mapeadas (seguindo a normalização sugerida em Mortazavi et al., 2008). O cálculo da expressão diferencial dos miRNAs 
entre as amostras tratadas e controle foi realizado pelo pacote edgeR (Robinson, et al. 2010) do Bioconductor (plataforma R, www.bioconductor.org/packages/2.9/bioc/html/edgeR.html).

\subsubsection{PREDIÇÃO DOS GENES REGULAdOS PELOS MIRNAS AFETADOS PELO SILENCIAMENTO DO GENE CODIFICADOR DA esterase do hormônio juvenil - jhe}

Para identificar os miRNAs candidatos a reguladores do gene jhe, procedeu-se uma busca por sítios de ligação para os miRNAs diferencialmente expressos entre os indivíduos tratados com dsjhe e controles na região 3' não-traduzida dos 11062 genes preditos para A. mellifera (Official Gene Set 2, HONEYBEE GENOME CONSORTIUM, 2006). Esta predição foi conduzida com auxílio do programa RNAhybrid (Rehmsmeier et al. 2004), considerando pareamento na região da seed (2-7 nt), valores de energia livre inferiores a $-20 \mathrm{kcal} / \mathrm{mol} \mathrm{e} p$-value menor que 0.05 .

Em seguida, recuperou-se os ortólogos de Drosophila melanogaster (www.flybase.org/) dos genes candidatos a alvo desses miRNAs de A. mellifera. A recuperação dos ortólogos nos permitiu identificar os processos biológicos (Gene Ontology; www.geneontology.org/) aos quais os genes candidatos estão associados. A identificação dos processos biológicos foi realizada através do plug in Bingo (Maere et al., 2005) executado na plataforma Cytoscape (www.cytoscape.org/).

Tabela 4: Identificação dos bancos de dados utilizados para mapear as reads das bibliotecas de pequenos RNAs extraídos de larvas tratadas com dsjhe e larvas controle de $A$. mellifera.

\begin{tabular}{|c|c|c|c|c|}
\hline $\begin{array}{l}\text { Sequências } \\
\text { Expressas }\end{array}$ & Base de dados & Organismos & $\begin{array}{l}\text { Número de } \\
\text { Sequências }\end{array}$ & Referência \\
\hline $\begin{array}{c}\text { Genes } \\
\text { codificadores }\end{array}$ & $\begin{array}{c}\text { Official Gene } \\
\text { Set (OGS } 2 \text { - } \\
\text { versão } 4.0 \\
\text { genoma) }\end{array}$ & A. mellifera & 11062 & http://genome.ucsc.edu/ \\
\hline miRNA & miRBase & A. mellifera & 168 & http://www.mirbase.org/ \\
\hline rRNA & SILVA & Insetos & 6820 & http://www.arb-silva.de/ \\
\hline tRNA & GtRNAdb & Insetos & 726 & http://gtrnadb.ucsc.edu/ \\
\hline $\begin{array}{c}\text { Outros } \\
\text { ncRNAs }\end{array}$ & NONCODE & Eucariotos & 423904 & http://www.noncode.org/NONCODERv3/ \\
\hline Patógenos & $\mathrm{NCBI}$ & $\begin{array}{c}\text { Bactérias, } \\
\text { Fungos e } \\
\text { Vírus } \\
\text { causadores de } \\
\text { doenças em } \\
\text { abelhas }\end{array}$ & 933 & http://www.ncbi.nlm.nih.gov/ \\
\hline
\end{tabular}


4. RESULTADOS 


\subsection{PERFIS DE EXPRESSÃO GÊNICA}

\subsection{1 cryptocephal (crc)}

Transcritos de $\operatorname{crc}$ são observados em rainhas e operárias em todas as fases do desenvolvimento analisadas (Figura 7). Nota-se, ao mesmo tempo, semelhanças e diferenças em relação à flutuação expressão de $\operatorname{crc}$ entre as castas. Nos estágios larvais iniciais, anteriores ao período crítico de determinação de castas (L4), os níveis de expressão de $\operatorname{crc}$ são basais. A partir de L4, os níveis de transcritos se elevam gradativamente e se diferem entre as castas, sendo mais elevados em operárias durante todo o período. Os níveis de $c r c$ são máximos em rainhas no $2^{\circ}$ estágio pré-pupal (PP2). Em operárias, o pico de expressão de $\operatorname{crc}$ ocorre no $3^{\circ}$ estágio pré-pupal (PP3). Observamos que o pico de expressão de $c r c$ em rainhas é menos pronunciado e está adiantado em relação àquele encontrado em operárias. Em ambas ocorre uma queda nos níveis de expressão deste gene a partir das fases imediatamente posteriores aos níveis máximos encontrados. A expressão de $\operatorname{crc}$ nas castas se mantém relativamente baixa até o final do estágio pupal, quando começam a subir novamente atingindo novos picos em Pbd em rainhas e em operárias recém-emergidas (RN). É interessante ressaltar que os níveis máximos de expressão do $c r c$, tanto em rainhas quanto em operárias, são observados em períodos prémetamórficos. São encontradas diferenças estatísticas significativas entre rainhas e operárias desde L5F1 até recém nascidas (RN), com exceção das fases, L5S3 e PP2 (Teste Mann-Whitney, p < 0,05).

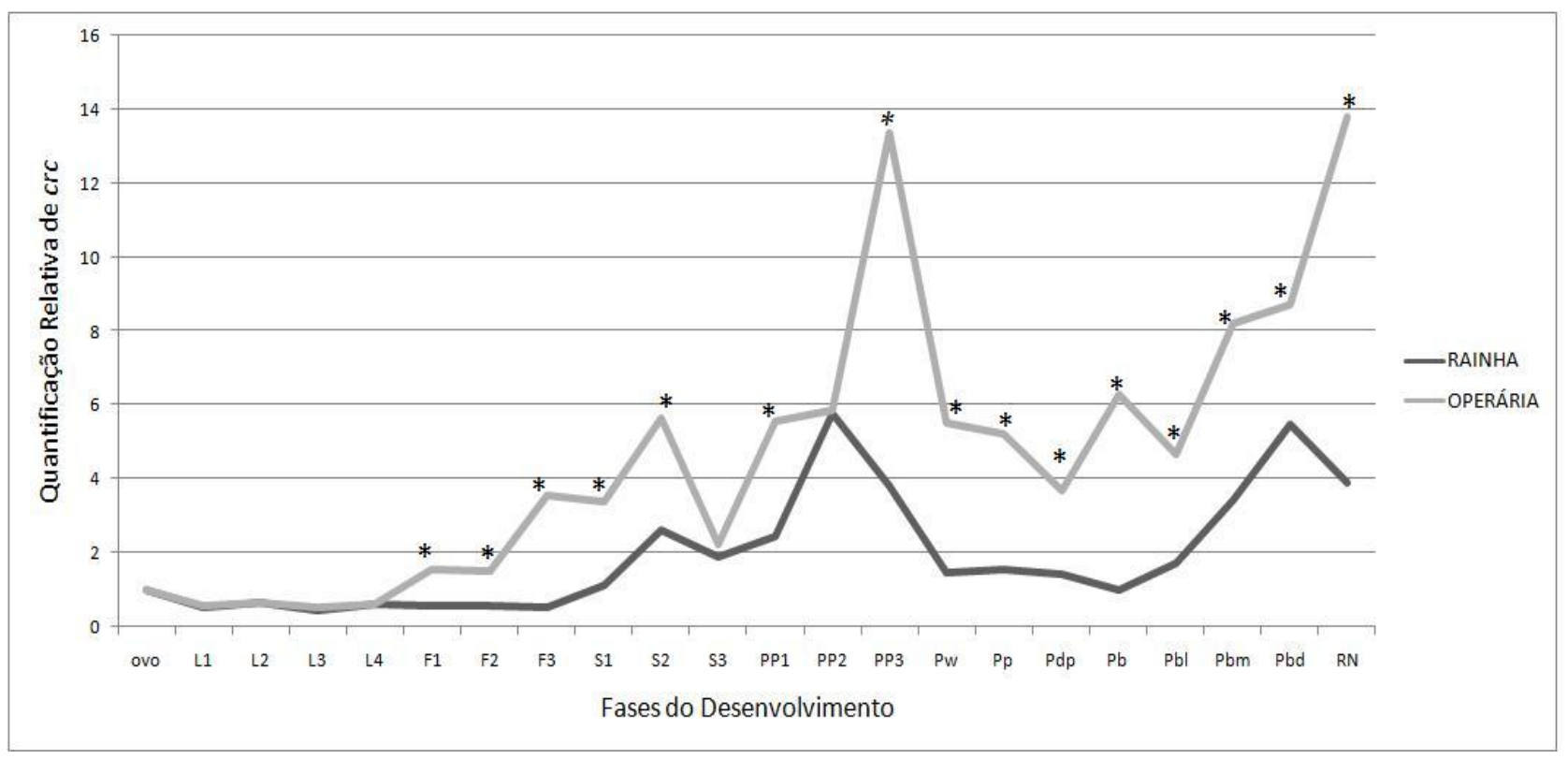

Figura 7: Expressão relativa do gene codificador de cryptocephal ( $\operatorname{crc}$ ) em diferentes estágios do desenvolvimento de operárias e rainhas de Apis mellifera. Os níveis de expressão do gene codificador de RP-49 foram utilizados como controle endógeno para normalizar os níveis de expressão de $c r c$. Os valores para cada estágio correspondem à média da expressão encontrada nas amostras $(n=3)$. Asteriscos indicam diferença estatística significativa de acordo com Teste Mann-Whitney $(\mathrm{p}<0,05)$. Ver Tabela 2 para fases do desenvolvimento. 


\subsection{2 retinoid- and fatty acid-binding protein - $R f a B p$}

O perfil de expressão de $R f a B p$ de rainhas e operárias de Apis mellifera mostra que este gene é expresso durante todo o desenvolvimento, apresentando muita semelhança entre ambas, exceto pelo $5^{\circ}$ instar larval (L5F e L5S). Assim como foi visto no perfil de $c r c$, os níveis de transcritos de $R f a B p$ são praticamente basais nos estágios iniciais onde ainda não ocorreu a determinação de castas (Figura 8). Em rainhas, a partir do $3^{\circ}$ estágio larval (L3), os níveis de transcritos começam a apresentar um aumento gradativo até L5F3, após o qual apresenta uma queda em L5S1 e subsequente elevação até atingir seus níveis máximos na fase L5S3 (Figura 8). Após esta fase, os níveis de mRNA de RfaBp caem novamente em rainhas, e se mantêm baixos até a emergência do adulto. Em operárias, os níveis de $R f a B p$ começam a aumentar a partir do $4^{\circ}$ estágio larval (L4), atingindo níveis máximos em L5F3. A partir de L5S1 os níveis de $R f a B p$ em operárias diminuem gradativamente e atingem níveis relativamente baixos desde o final do estágio pré-pupal até a emergência do adulto. Observamos que o pico de expressão de Rfabp em operárias é adiantado em relação ao observado em rainhas e que os níveis de expressão deste gene encontrados desde a fase L5F2 até recém- nascidas (RN), com exceção de L5S2 e Pbd, são estatisticamente diferentes entre as castas, de acordo com Teste Mann-Whitney $(\mathrm{p}<0,05)$.

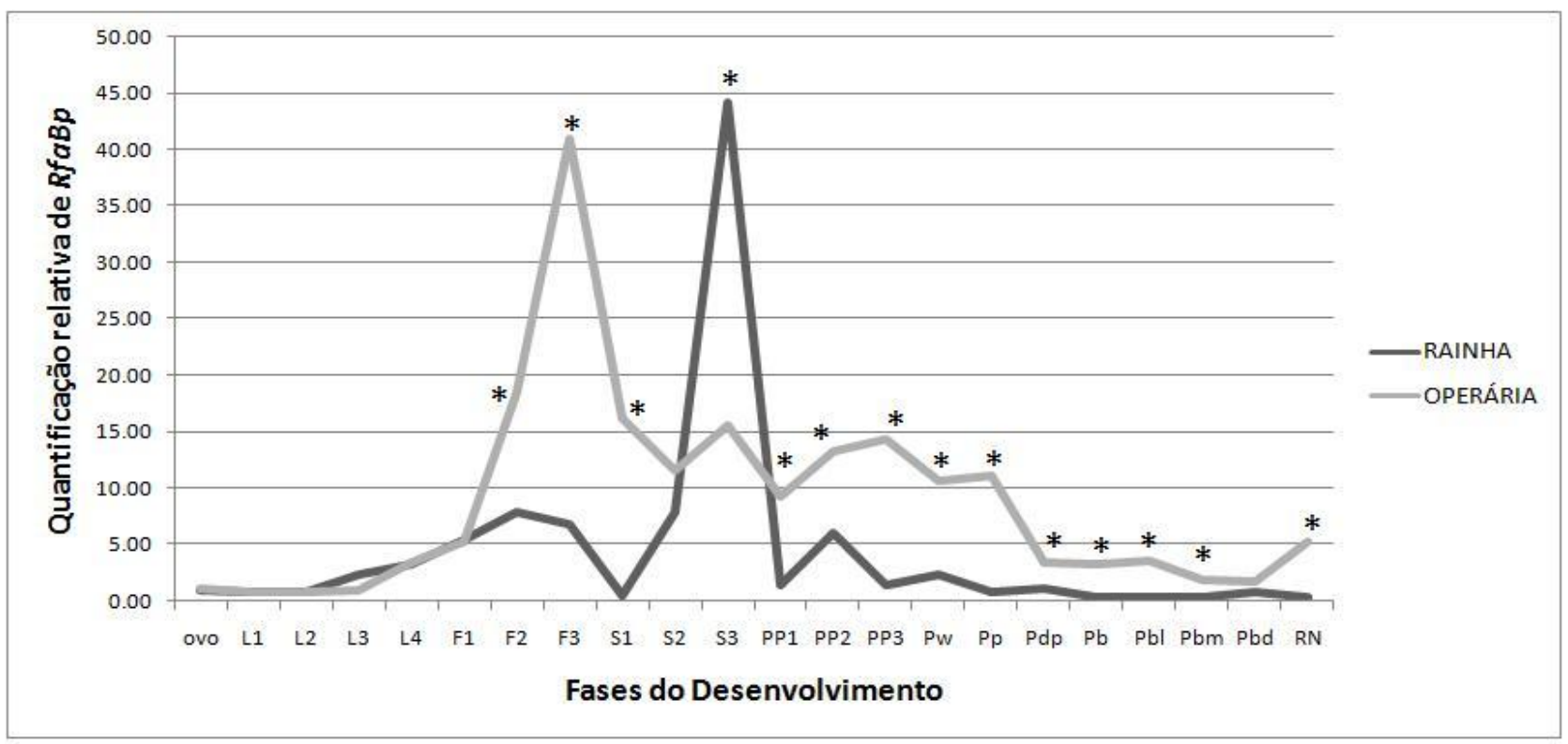

Figura 8: Expressão relativa do gene codificador de retinoid- and fatty acid-binding protien (RfaBp) em diferentes estágios do desenvolvimento de operárias e rainhas de Apis mellifera. Os níveis de expressão do gene codificador de RP-49 foram utilizados como controle endógeno para normalizar os níveis de expressão de $R f a B p$. Os valores para cada estágio correspondem à média da expressão encontrada nas amostras $(n=3)$. Asteriscos indicam diferença estatística significativa de acordo com Teste Mann-Whitney $(\mathrm{p}<0,05)$. Ver Tabela 2 para fases do desenvolvimento. 


\subsection{3 ultraspiracle (usp)}

Observamos que a transcrição do gene codificador de usp ocorre durante todo o desenvolvimento, tanto em rainhas quanto em operárias. O perfil de expressão de usp é muito semelhante entre as castas, exceto nas fases L5F e PP3 (Figura 9), em que operárias apresentam níveis relativamente mais altos que rainhas. Em operárias, na fase PP3, podemos observar o mais pronunciado pico de expressão de usp, após o qual, os níveis do gene sofrem uma queda e voltam a subir no final do estágio pupal. Em rainhas, os maiores níveis de expressão de usp ocorrem em L5S2, sofrendo uma queda no estágio subsequente (L5S3) e voltando a subir em PP, onde apresenta níveis equivalentes aos encontrados em L5S2. Após esta fase começa a cair, atingindo um mínimo em $\mathrm{Pb}$. Assim como observado em operárias, no final do estágio pupal os níveis de $u s p$ em rainhas sobem e atingem um outro pico em Pbd e caem novamente em RN. Encontramos diferença estatística significativa (Teste Mann-Whitney, $\mathrm{p}<0,05$ ), em relação aos níveis de expressão de usp encontrados, para rainha e operária nas fases de desenvolvimento L3, L5F2, L5F3, L5S1, PP3, Pb e Pbd.

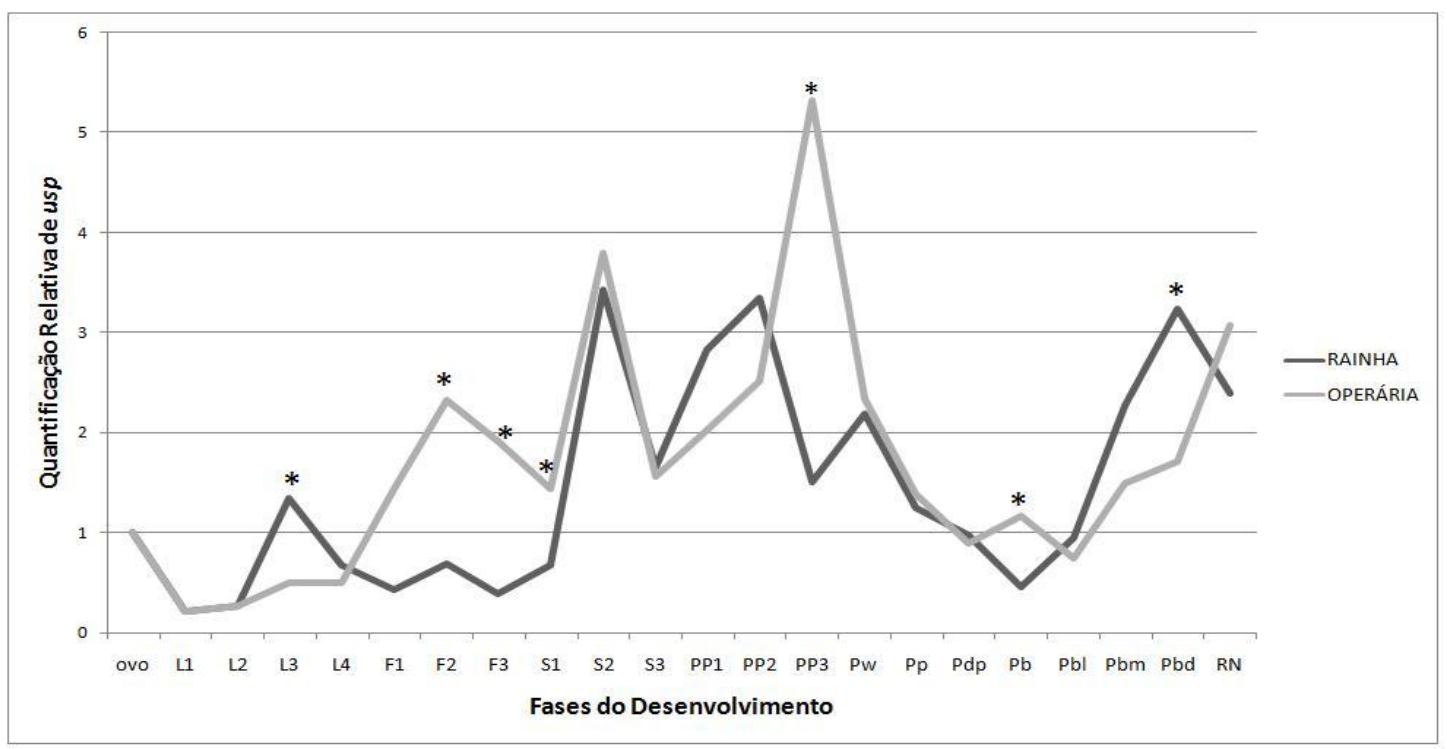

Figura 9: Expressão relativa do gene codificador de ultraspiracle (usp) em diferentes estágios do desenvolvimento de operárias e rainhas de Apis mellifera. Os níveis de expressão do gene codificador de RP-49 foram utilizados como controle endógeno para normalizar os níveis de expressão de usp. Os valores para cada estágio correspondem à média da expressão encontrado nas amostras $(n=3)$. Asteriscos indicam diferença estatística significativa de acordo com Teste Mann-Whitney $(\mathrm{p}<0,05)$. Ver Tabela 2 para fases do desenvolvimento. 


\subsection{ANÁLISE DE EXPRESSÃO DIFERENCIAL POR MICROARRAYS}

Visando encontrar genes diferencialmente expressos envolvidos na diferenciação de castas, foram realizados estudos de expressão gênica em larga escala usando a tecnologia de microarrays. Foram comparadas amostras de rainhas e operárias de A. mellifera em L4, fase imediatamente posterior ao período crítico de determinação de castas. Um total de 8.244 transcritos está expresso nas amostras estudadas e foram incluídos em nossas análises subsequentes. Ao nível significância FDR01 (False Discovery Rate 0,01\%), encontramos 670 transcritos diferencialmente expressos entre os grupos (Anexo 5), sendo que para 432 destes genes foram encontrados ortólogos em Drosophila. Observamos que a maioria dos genes diferencialmente expressos encontrados apresentam expressão preferencial em operárias, 438 contra 231 preferencialmente expressos em rainhas dentre os 670 encontrados (Anexo 5A). Foi realizado um agrupamento hierárquico (Hierarchical Cluster) destes genes diferencialmente expressos, considerando genes inibidos ou ativados em uma das castas em relação à outra. Conforme ilustrado na Figura 10, houve separação das amostras em dois diferentes grupos, um deles constituído pelas amostras de rainhas e outro pelas amostras de operárias. Análises funcionais com base nos termos do Gene Ontology (GO), utilizando o programa DAVID, agruparam os genes diferencialmente expressos entre as castas em 59 grupos (ou clusters) distintos, indicando processos biológicos nos quais estes genes estão envolvidos (Tabela completa - Anexo 5B). Foram feitas análises de GO individuais para os genes preferencialmente expressos em cada uma das castas, por meio das quais podemos destacar 22 categorias de processos biológicos (Tabela 5). A categoria de genes relacionados à resposta imune, preferencialmente expressos em operárias foi a mais representativa entre elas. Outros processos biológicos também se mostraram representativos, entre eles metamorfose, neurogênese, morte celular, regulação da transcrição, reprodução, regulação de processos de biossíntese e crescimento (Tabela completa - Anexo 5B).

Como o objetivo deste trabalho reside em encontrar fatores moleculares determinantes de operárias, propusemos uma "Top list" contendo genes que apresentaram expressão preferencial nesta casta (Tabela 6). Eles estão envolvidos em processos biológicos como morte celular programada (apoptose), neurogênese, degradação de hormônio juvenil, aprendizagem olfativa, composição do citoesqueleto, entre outros. Entre os genes da "top list", encontramos o codificador da esterase do hormônio juvenil (jhe) e decidimos incluí-lo em análises subsequentes. 


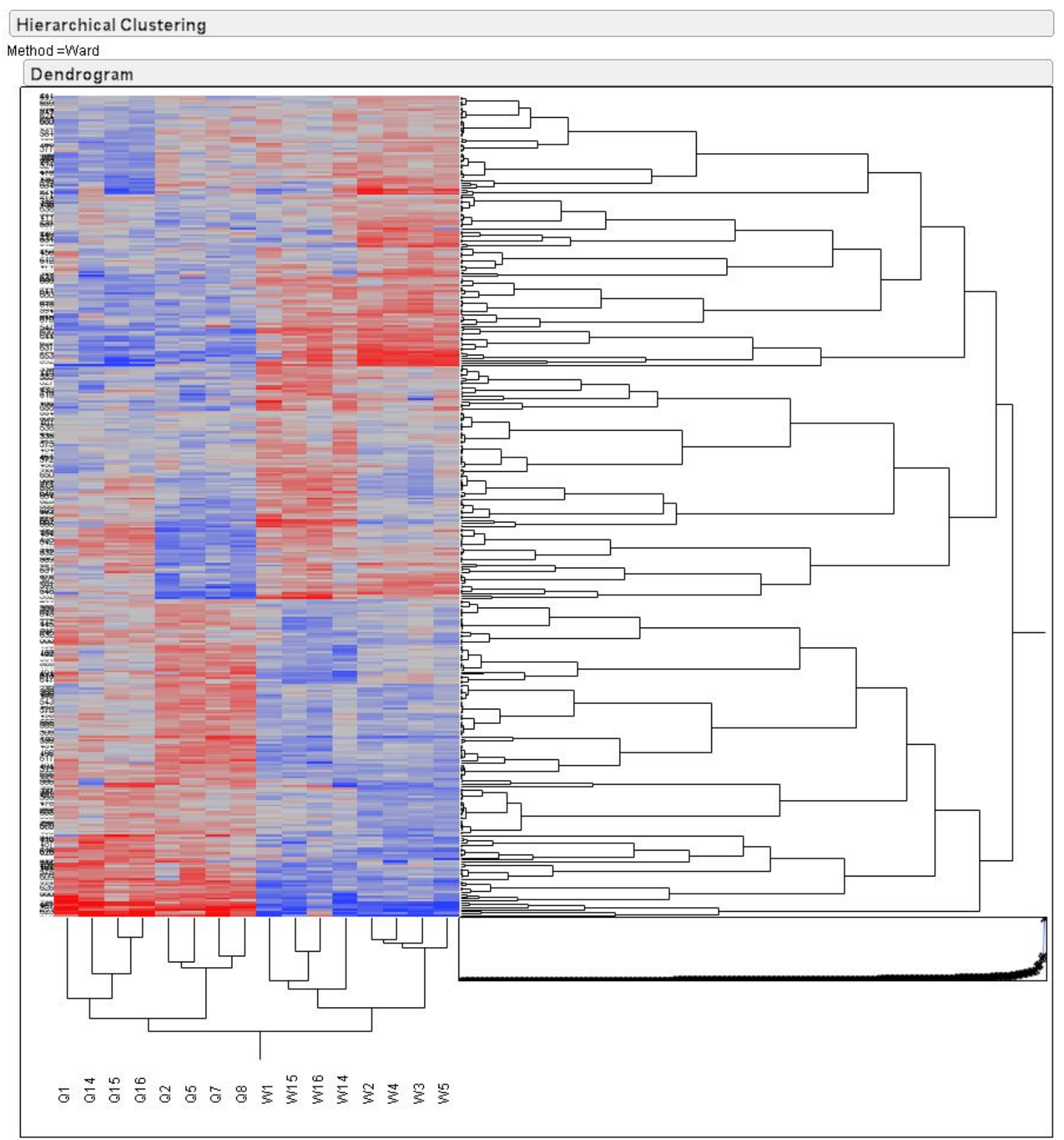

Figura 10: Dendrograma mostrando o agrupamento hierárquico, de acordo com os níveis de expressão diferencial entre rainhas (Q) e operárias (W) de Apis mellifera no quarto estágio larval (L4). Blocos azuis representam genes inibidos e blocos vermelhos representam genes ativados de acordo seus níveis de expressão determinados por análises de microarrays. 
Tabela 5: Análises de GO realizadas no programa DAVID (http://david.abcc.ncifcrf.gov) mostrando os processos biológicos nos quais estão envolvidos a maior parte dos genes diferencialmente expressos entre rainhas e operárias no estágio L4 (obtidos por análises de microarrays). Células cinza escuro: categorias mais representativas em rainhas de acordo com genes preferencialmente expressos, células cinza claro: categorias mais representativas em operárias de acordo com genes preferencialmente expressos; células sem preenchimento: categorias igualmente representadas em ambas as castas.

\begin{tabular}{|c|}
\hline Processo Biológico \\
\hline Respiração Celular \\
\hline Morfogênese pós-embrionária \\
\hline Organização e modificação da cromatina \\
Adesão celular \\
\hline Localização celular \\
\hline Resposta imune \\
\hline Óxido-Redução \\
\hline EGF \\
\hline Homeostase \\
\hline Morte Celular \\
\hline Processos de crescimento e tamanho celular \\
\hline Metamorfose \\
\hline Processos de desenvolvimento \\
\hline Neurogênese \\
\hline Reprodução \\
\hline Regulação de processos biossintéticos \\
\hline Regulação da Transcrição \\
\hline Transporte celular \\
\hline
\end{tabular}


Tabela 6: "Top list" dos genes preferencialmente expressos em operárias no $4^{\circ}$ estagio larval (L4). Função biológica determinada de acordo com o banco de dados Gene Ontology, associados à espécie Drosophila melanogaster (disponível no portal FlyBase - www.flybase.org). Em negrito o gene da esterase do homônio juvenil, incluído nas análises feitas neste trabalho por apresentar expressão diferencial entre as castas e por atuar na degradação do HJ.

\begin{tabular}{|c|c|}
\hline GB/nome do gene & Processo Biológico \\
\hline GB16903 - cathD & \multicolumn{1}{|c|}{ Morte celular autofágica } \\
\hline GB17380 - failed axon (fax) & \multicolumn{1}{|c|}{ Axogênese } \\
\hline GB17541 & \multicolumn{1}{|c|}{ Regulação positiva da apoptose } \\
\hline $\begin{array}{c}\text { GB15327 - esterase do } \\
\text { hormônio juvenil (jhe) }\end{array}$ & \multicolumn{1}{|c|}{ Catabolismo de Hormônio Juvenil* } \\
\hline GB11753 - Atf3 & \multicolumn{1}{|c|}{ Resenvolvimento do sistema nervoso } \\
\hline GB19301- PGRP-SC2 & $\begin{array}{l}\text { Aprendizagem olfativa, organização do citoesqueleto, } \\
\text { regulação negativa da apoptose neuronal, morfogênese } \\
\text { dendrítica, axonogênese; transporte de carga nos axônios; } \\
\text { regulação do crescimento sináptico nas junções neuro- } \\
\text { musculares }\end{array}$ \\
\hline GB11509- futsch & \\
\hline
\end{tabular}

\subsection{ANÁLISE DO PERFIL DE EXPRESSÃO DO GENE CODIFICADOR DA esterase do hormônio juvenil (jhe)}

Análises comparativas entre os níveis de mRNA de jhe realizadas durante todo o desenvolvimento rainhas e operárias de $A$. mellifera mostraram alta expressão desse gene durante o período L5 (L5F e L5S), momento este que são observadas diferenças entre as castas . Nas fases anteriores e posteriores a este período os níveis de jhe são basais tanto em rainhas quanto em operárias (Figura 11). As operárias apresentam os maiores níveis de expressão que rainhas de L5F1 a L5S1 (segundo o Teste Mann-Whitney, $\mathrm{p}<0,05$ ), enquanto a abundância de mRNA de jhe em rainhas é maior que em operárias em L5S2. Encontramos diferença estatística significativa entre os níveis de expressão de jhe em rainhas e operárias para os estágios de desenvolvimento posteriores a L3, excetuando-se L5S3, PP2 e Pbd (Figuras 10A e 10B) (segundo o Teste Mann-Whitney, p $<0,05$ ).

Na mesma linha de investigação de genes relacionados ao metabolismo de $\mathrm{HJ}$, determinamos os níveis de expressão do gene codificador da enzima responsável pela última etapa da síntese do HJ, a metilfarnesoato-epoxidase (MFE). Tal quantificação foi realizada nas fases em que os níveis de expressão da jhe 
eram os mais altos em operárias, L5F3, e em rainhas, L5S2, e em uma fase onde eram basais em ambas $(\mathrm{Pb})$ (Figura 12). Em L5F3 e L5S2 os níveis de expressão de $m f e$ em rainhas são mais altos que em operárias e, em $\mathrm{Pb}$ os níveis deste gene são basais em ambas as castas. As diferenças encontradas entre rainhas e operárias nas fases F3 e S2 são estatisticamente significativas (Teste Mann-Whitney, p < 0,05).

(A)

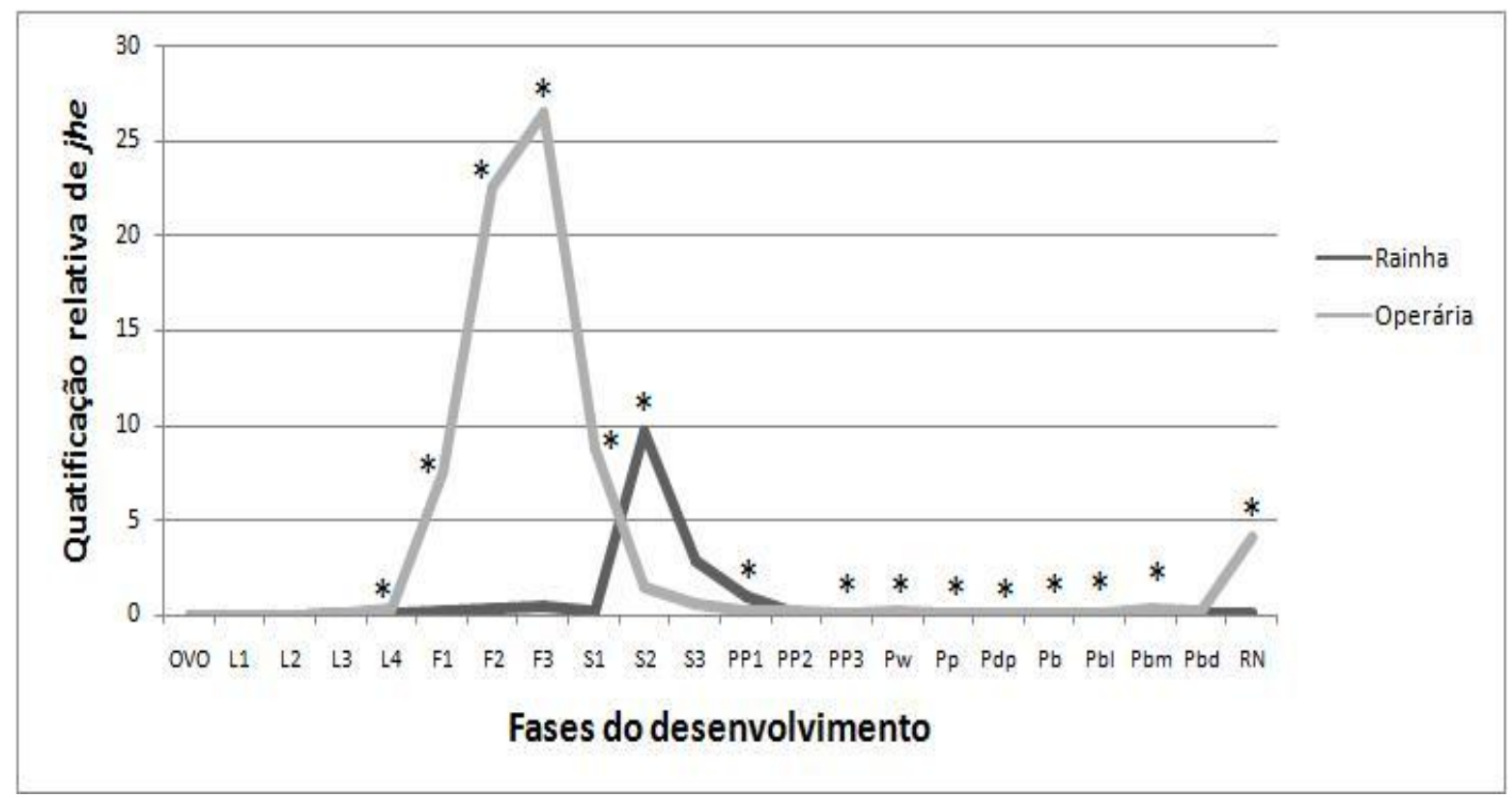

(B)

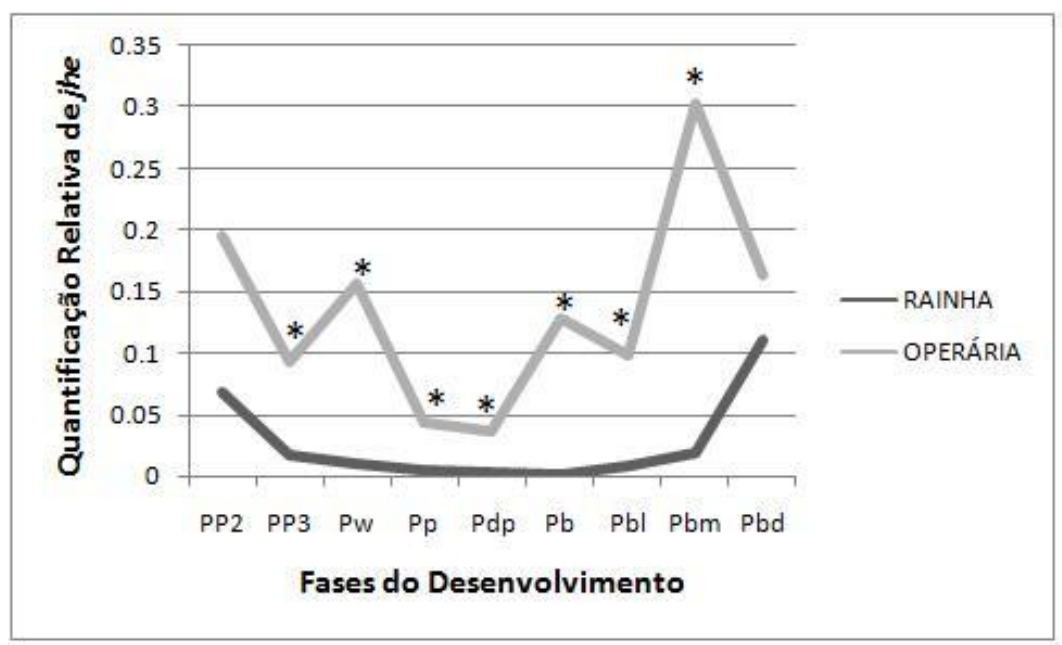

Figura 11: Expressão relativa do gene codificador da esterase do hormônio juvenil (jhe) em diferentes estágios do desenvolvimento de operárias e rainhas de Apis mellifera. (A) Níveis de jhe em todas as fases de desenvolvimento estudadas. (B) Níveis de jhe a partir da segunda fase do estágio Pré-pupal até o final do estágio pupal, evidenciando a diferença existente entre os níveis de expressão do gene nas fases. Os níveis de expressão do gene codificador de RP-49 foram utilizados como controle endógeno para normalizar os níveis de expressão de jhe. Os valores para cada estágio correspondem à média da expressão encontrado nas amostras $(n=3)$. Asteriscos indicam diferença estatística significativa de acordo com Teste MannWhitney $(\mathrm{p}<0,05)$. Ver Tabela 2 para fases do desenvolvimento. 


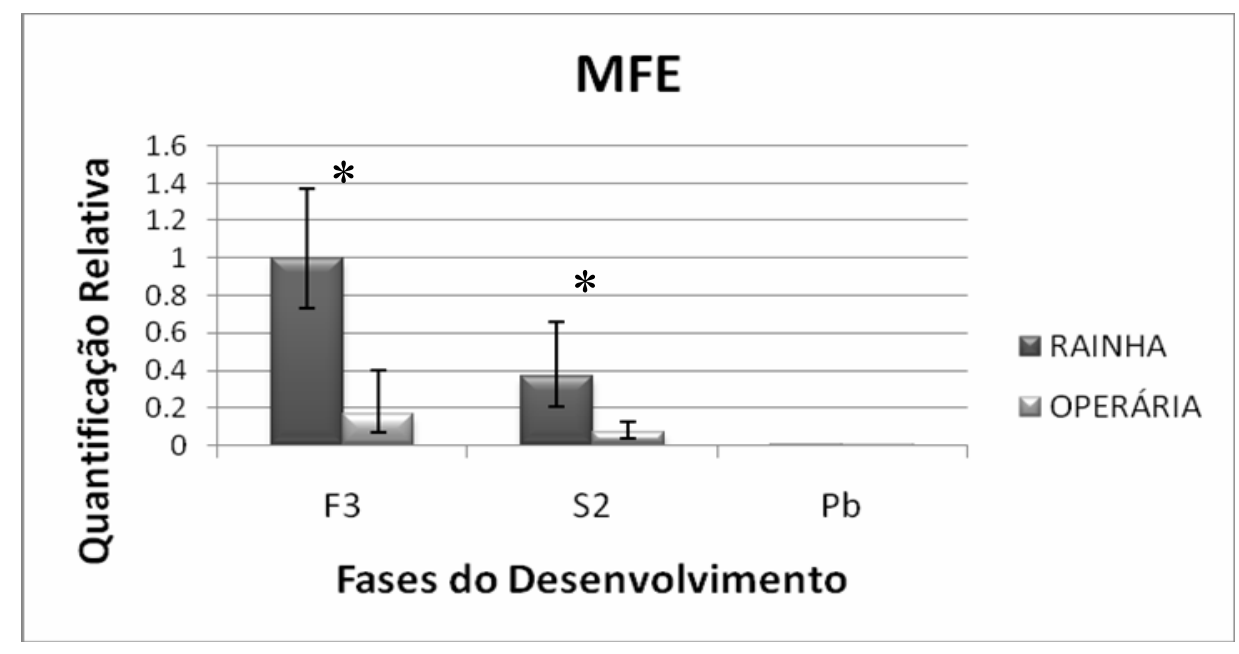

Figura 12: Expressão relativa do gene codificador da metil-farnesoato-epoxidase $(m f e)$ em diferentes estágios do desenvolvimento de operárias e rainhas de Apis mellifera. Os níveis de expressão do gene codificador de RP-49 foram utilizados como controle endógeno para normalizar os níveis de expressão de $m f e$. Os valores para cada estágio correspondem à média da expressão encontrado nas amostras $(n=3)$. Asteriscos indicam diferença estatística significativa de acordo com Teste Mann-Whitney $(\mathrm{p}<0,05)$. Ver Tabela 2 para fases do desenvolvimento.

\subsection{SILENCIAMENTO GÊNICO POR RNAi}

Nesta etapa, nosso intuito foi analisar a possível participação de ultraspiracle (usp), cryptocephal (crc), retinoid- and fatty acid-binding protein (RfaBp) e da esterase do hormônio juvenil, (jhe) no processo de desenvolvimento de castas. Em particular, procuramos investigar se tais genes atuam em redes de expressão gênica que favorecem a determinação de operárias, analisando seus papéis sobre a expressão de um em relação ao outro, além de outro gene potencialmente relacionados a este processo, o $E c R$.

\subsection{1 cryptocephal - crc}

Para os indivíduos tratados com o RNA de fita dupla para o gene $\operatorname{crc}$ (dscrc) não foram observadas alterações visíveis na morfologia e nem em relação ao timing do desenvolvimento. Observamos uma queda de $20 \%$, que representa a média dos níveis de expressão de $c r c$ encontrados individualmente nas amostras tratadas $(n=8)$ em relação ao controle ( $\mathrm{n}=3)$ (Figura 13). A comparação entre as médias encontradas para o grupo-controle e o grupo-tratamento não apresentaram diferença estatística (Segundo Teste Mann-Whitney - $\mathrm{p}<0,05$ ). Os níveis de expressão de $R f a B p, u s p, j h e, E c R$ A e $E c R$-B foram analisados nas amostras do experimento acima. Observamos um aumento nos níveis de expressão de $R f a B p$ e $E c R$-A $(\mathrm{p}<0,05)$ nas amostras tratadas relação aos controles (Figura 14). 


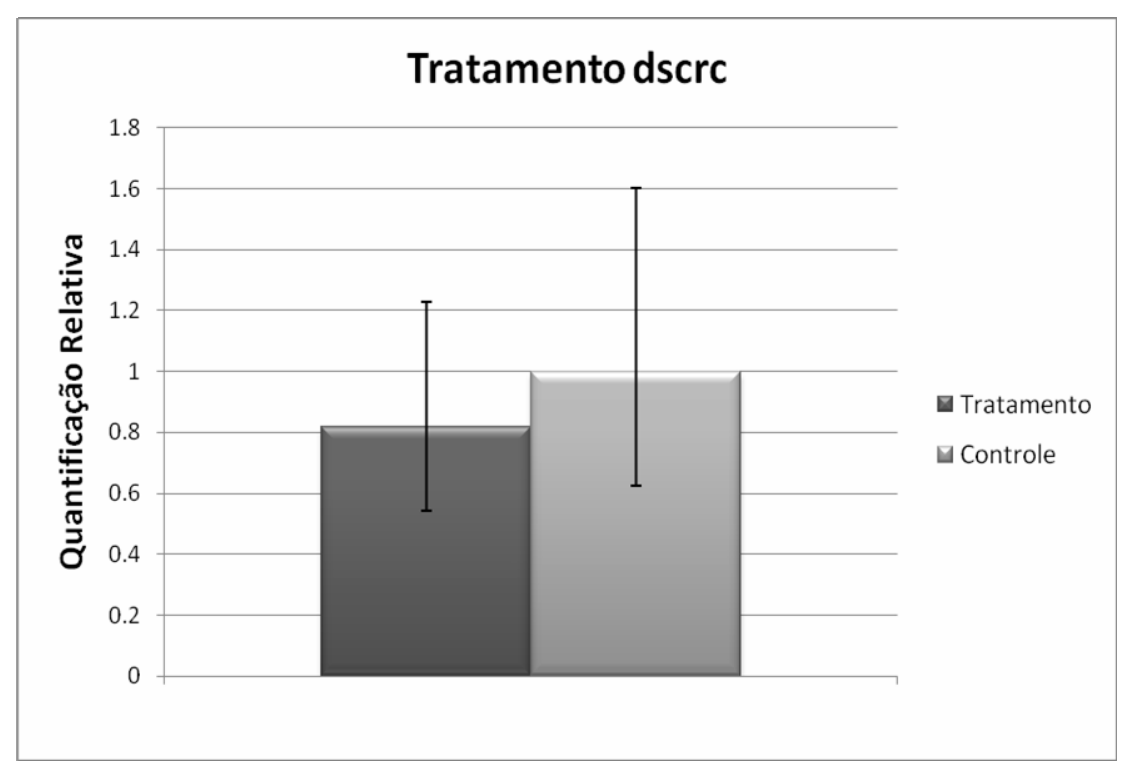

Figura 13: Quantificação relativa de mRNAs do gene codificador cryptocephal ( $\operatorname{crc}$ ) em larvas de operárias de Apis mellifera, no estágio de desenvolvimento L5-S1 sem tratamento (Controle, $\mathrm{n}=3$ ) e tratadas no segundo estágio larval, L2 com 1,0 $\mu$ g de dscrc $(n=8)$. Os valores de expressão obtidos para o gene codificador de RP-49 foram utilizados para normalização da expressão de $c r c$. Os dados de cada grupo correspondem à média da expressão das amostras. As linhas representam o desvio padrão. A expressão relativa foi calculada de acordo com o que foi proposto por Livak \& Schmittgen (2001). Não houve diferença estatística significativa de acordo com Teste Mann-Whitney $(\mathrm{p}<0,05)$ entre as amostas tratadas e controle. 

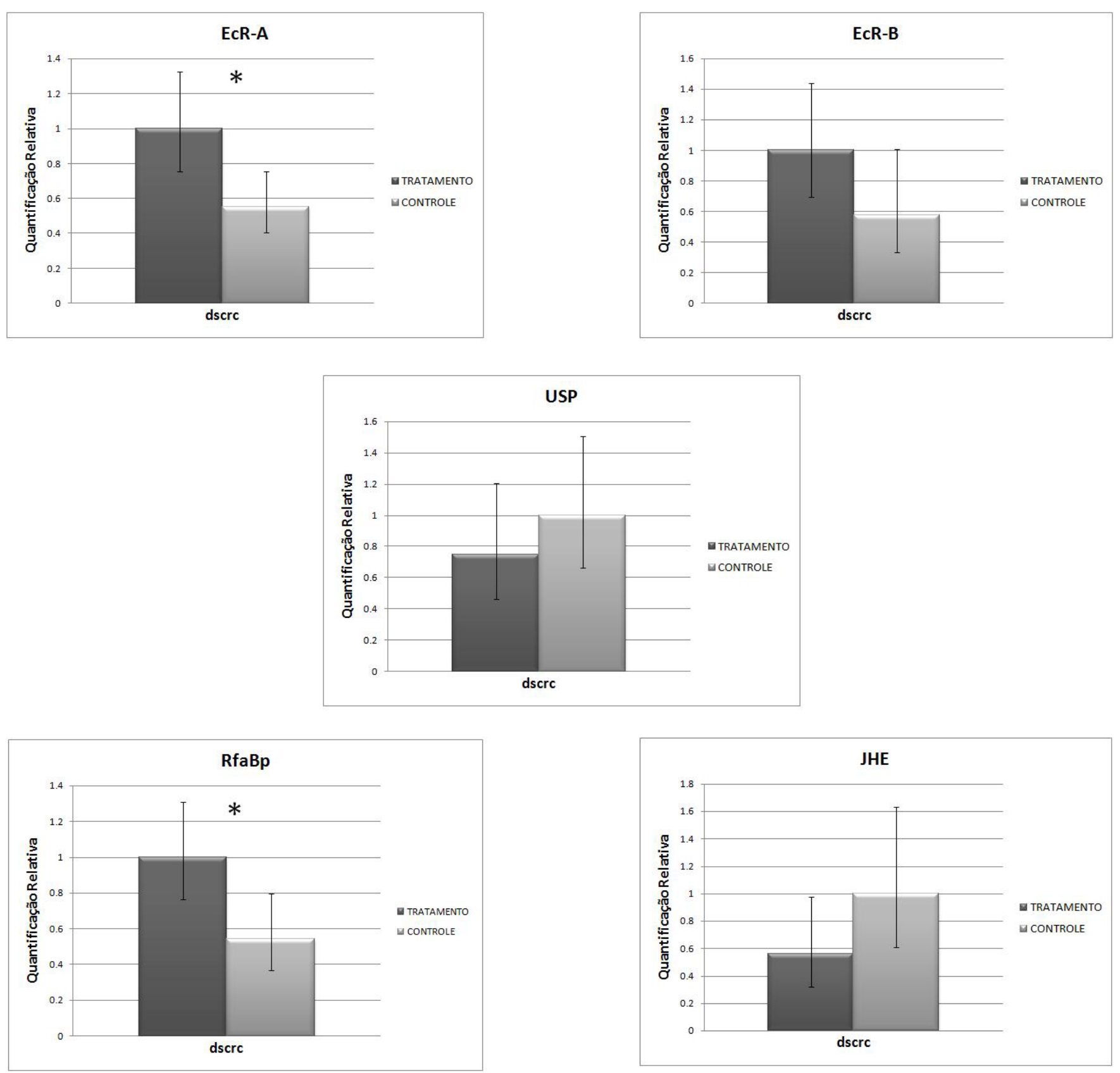

Figura 14: Quantificação relativa de mRNAs dos genes codificadores de $E c R$ variante A (EcR-A); $E c R$ variante $\mathrm{B}$ (EcR-B); ultraspiracle (usp); retinoid-and fatty acid-binding protein (RfaBp) e esterase do hormônio juvenil (jhe); em amostras tratadas com $1,0 \mu \mathrm{g}$ de dscrc $(\mathrm{n}=5)$ e controles sem tratamento $(\mathrm{n}=3)$. Os valores obtidos para o gene codificador de RP-49 foram utilizados para normalização. Os dados de cada grupo correspondem à expressão da média das amostras, e as linhas representam o desvio padrão. A expressão relativa foi calculada de acordo com o que foi proposto por Livak \& Schmittgen (2001). Asteriscos indicam diferença estatística significativa de acordo com Teste Mann-Whitney $(\mathrm{p}<0,05)$ entre as amostas tratadas e controle. 


\subsection{2 retinoid- and fatty acid-binding protein - $R f a B p$}

Os indivíduos tratados com dsRNA para o gene $R f a B p$ não apresentaram diferenças morfológicas observáveis, nem em relação ao tempo de desenvolvimento, quando comparados com os indivíduos do grupo controle. Graficamente, notamos uma diminuição de aproximadamente $60 \%$ nos níveis de $R f a B p$ nas amostras tratadas com dsRfaBp (Figura 15). Foi observada diferença estatística entre controle e tratamento com dsRfaBp, de acordo com Teste Mann-Whitney ( $\mathrm{p}<0,05)$. Outras análises, em relação aos níveis de expressão, foram realizadas utilizando os genes $c r c$, usp, jhe, $E c R$-A e $E c R$-B. Notamos que os níveis de expressão de $R f a B p$ são capazes de influenciar negativamente a transcrição de $j h e(\mathrm{p}<0,05)$ (Figura 16).

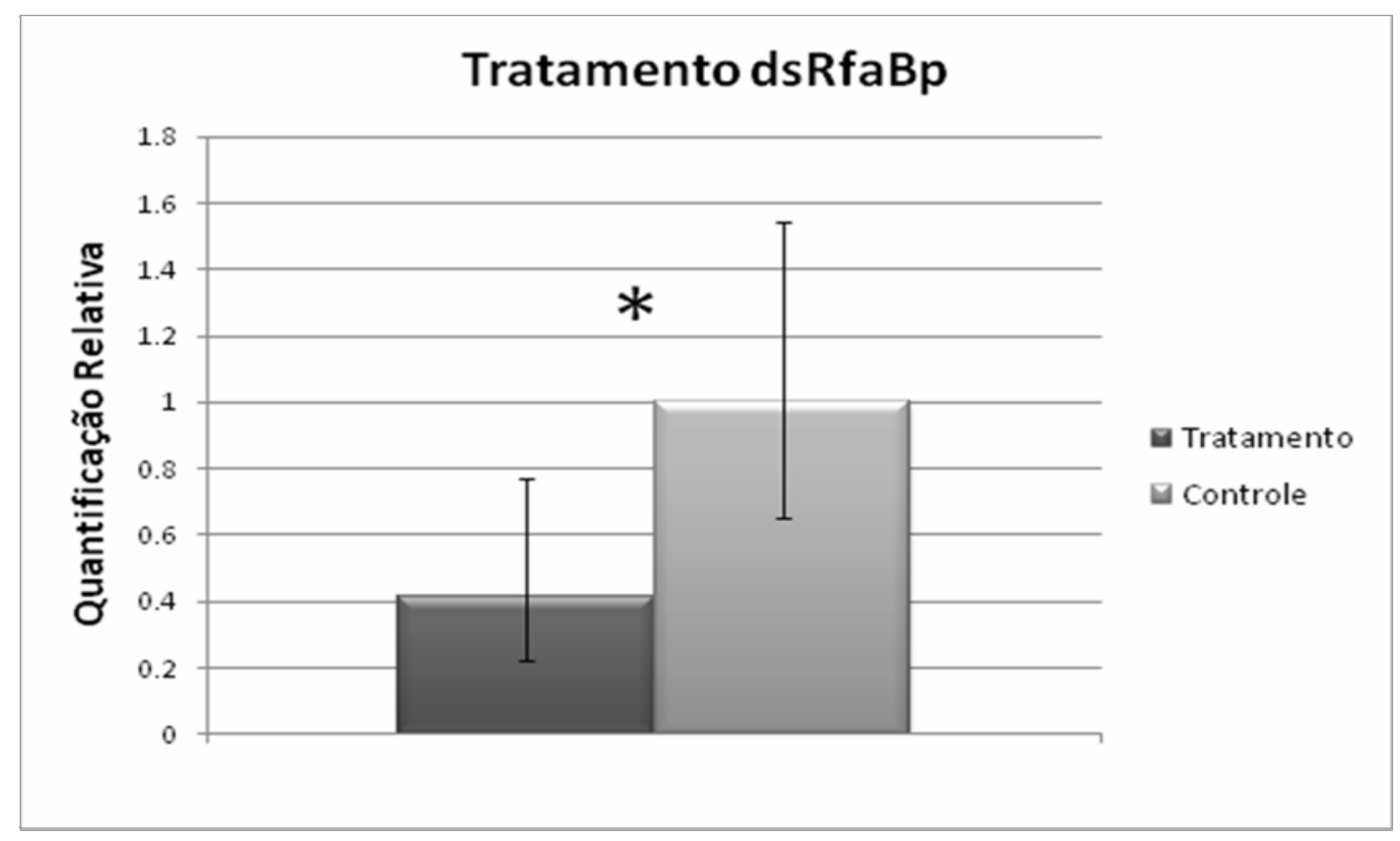

Figura 15: Quantificação relativa de mRNAs do gene codificador de retinoid- and fatty acid-binding protein (RfaBp) em larvas de operárias de Apis mellifera, no estágio de desenvolvimento L5S1 sem tratamento (Controle, $\mathrm{n}=3$ ) e tratadas no segundo estágio larval, L2 com 1,0 $\mu \mathrm{g}$ de dsRfaBp (n=10). Os valores de expressão obtidos para o gene codificador de RP-49 foram utilizados para normalização da expressão de $R f a B p$. Os dados de cada grupo correspondem à média da expressão das amostras. As linhas representam o desvio padrão. A expressão relativa foi calculada de acordo com o que foi proposto por Livak \& Schmittgen (2001). Asteriscos indicam diferença estatística significativa de acordo com Teste Mann-Whitney $(p<0,05)$ entre as amostas tratadas e controle. 

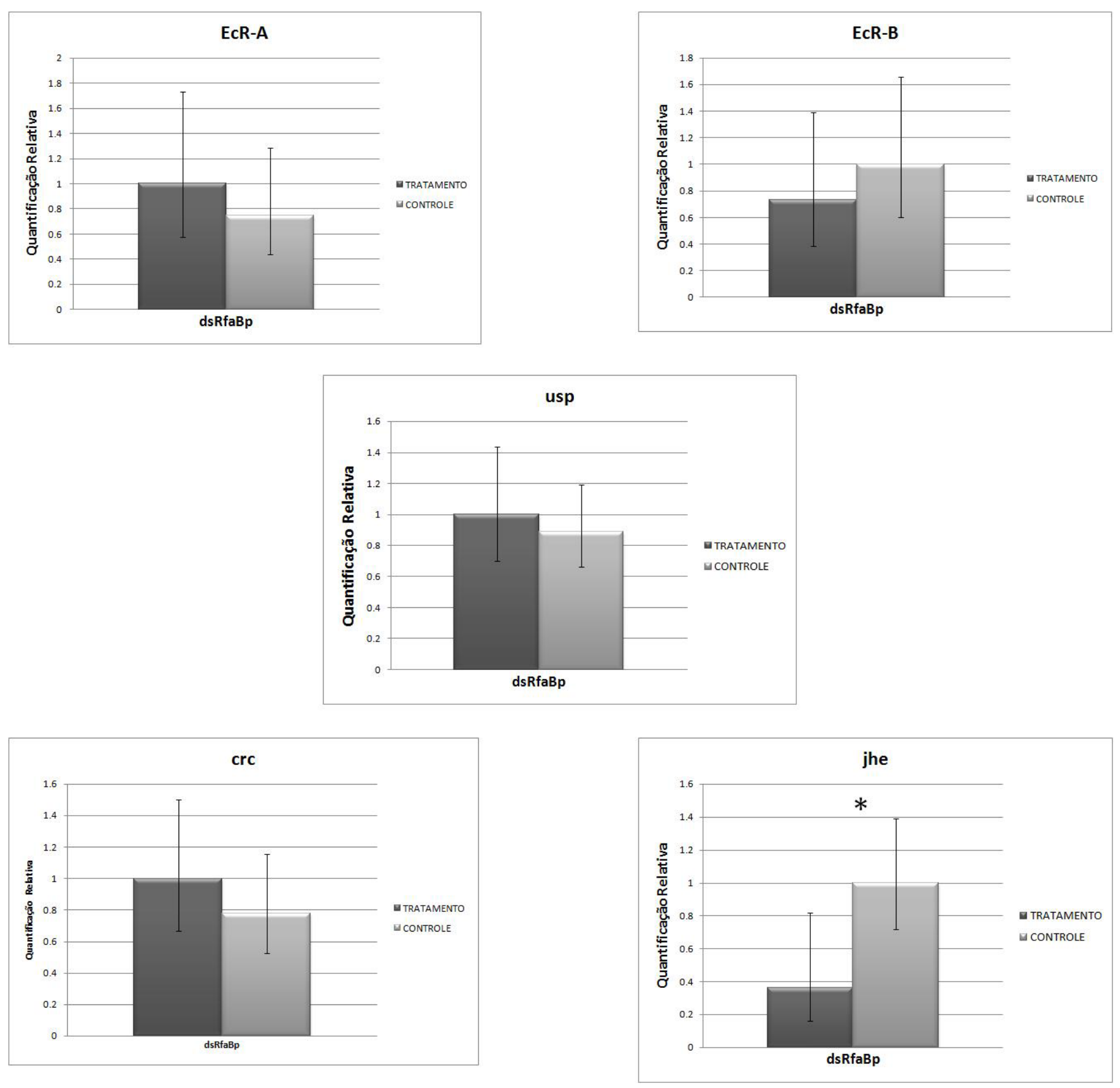

Figura 16: Quantificação relativa de mRNAs dos genes codificadores de $E c R$ variante A (EcR-A); $E c R$ variante $\mathrm{B}$ (EcR-B); ultraspiracle (usp); cryptocephal (crc) e esterase do hormônio juvenil (jhe); em amostras tratadas com $1,0 \mu \mathrm{g}$ de dsRfaBp $(\mathrm{n}=5)$ e seus controles $(\mathrm{n}=3)$ para os quais nenhum dsRNA foi administrado. Os valores obtidos para o gene codificador de RP-49 foram utilizados para normalização. Os dados de cada grupo correspondem à média da expressão da média das amostras. As linhas representam o desvio padrão. A expressão relativa foi calculada de acordo com o que foi proposto por Livak \& Schmittgen (2001). Asteriscos indicam diferença estatística significativa de acordo com Teste Mann-Whitney $(p<0,05)$ entre as amostas tratadas e controle. 


\subsection{3 ultraspiracle - usp}

Foram realizados experimentos de interferência por RNA para o gene usp. Os indivíduos tratados com dsusp e controle foram coletados em duas diferentes fases do desenvolvimento PP e em Pbl. Para os indivíduos coletados em PP não foram observadas diferenças morfológicas visíveis quando se comparou indivíduos tratados e controle, e diferenças em relação ao timing do desenvolvimento também não foram observadas. Quando comparamos os níveis de expressão de usp nas amostras obtidas a partir destes indivíduos, observamos uma queda de $50 \%$ em média no tratamento $(n=3)$ em relação ao controle $(n=3)$ (Figura 18A), apresentando diferença estatística significativa (Teste Mann-Whitney, $\mathrm{p}<0,05$ ). Diferentemente do que foi observado para os indivíduos em PP, os indivíduos tratados que deveriam ser coletados em Pbl estavam em fase de desenvolvimento anterior, Pw (Figura 17). Este atraso observado corresponde a aproximadamente 140 horas em relação aos indivíduos controles que, como esperado, estavam na fase Pbl. Quando comparamos os resultados obtidos para as médias das amostras controle $(n=4)$ e tratamento, $(n=3)$ observamos um decréscimo nos níveis de transcritos usp nas amostras tratadas de aproximadamente 30\% (Figura 18B). Para esta fase podemos dizer que os grupos amostrais são marginalmente diferentes $(p=0,07)$, segundo Teste Mann-Whitney.

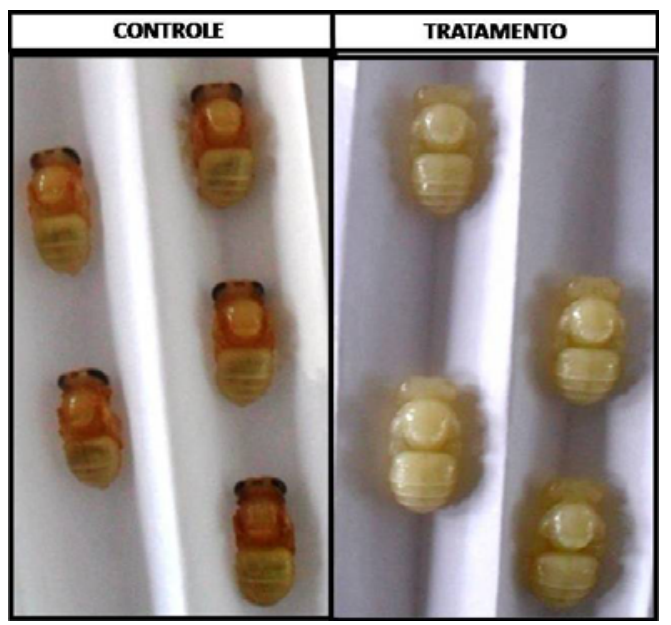

Figura 17: Pupas de operárias de Apis mellifera nas quais se observa um atraso no desenvolvimento, sendo os dois grupos provenientes da mesma postura que foi feita de maneira controlada e mantidas em caixa com tela excluidora para evitar que a rainha botasse novamente. TRATAMENTO: operárias tratadas em L2 $\left(2^{\circ}\right.$ instar larval) com $5 \mu \mathrm{g}$ de RNA dupla-fita para o gene $u s p$ (dsusp); CONTROLE: operárias para as quais nenhum tipo de tratamento foi administrado. 
(A)

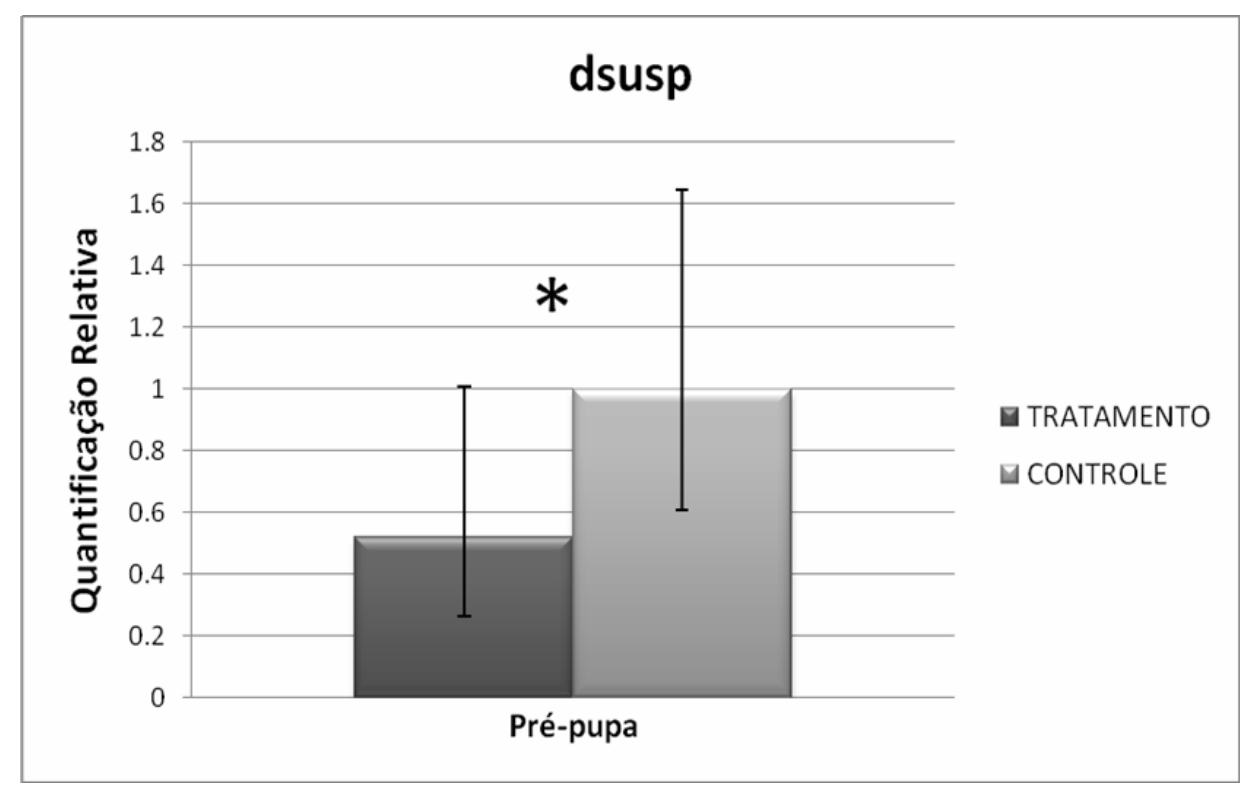

(B)

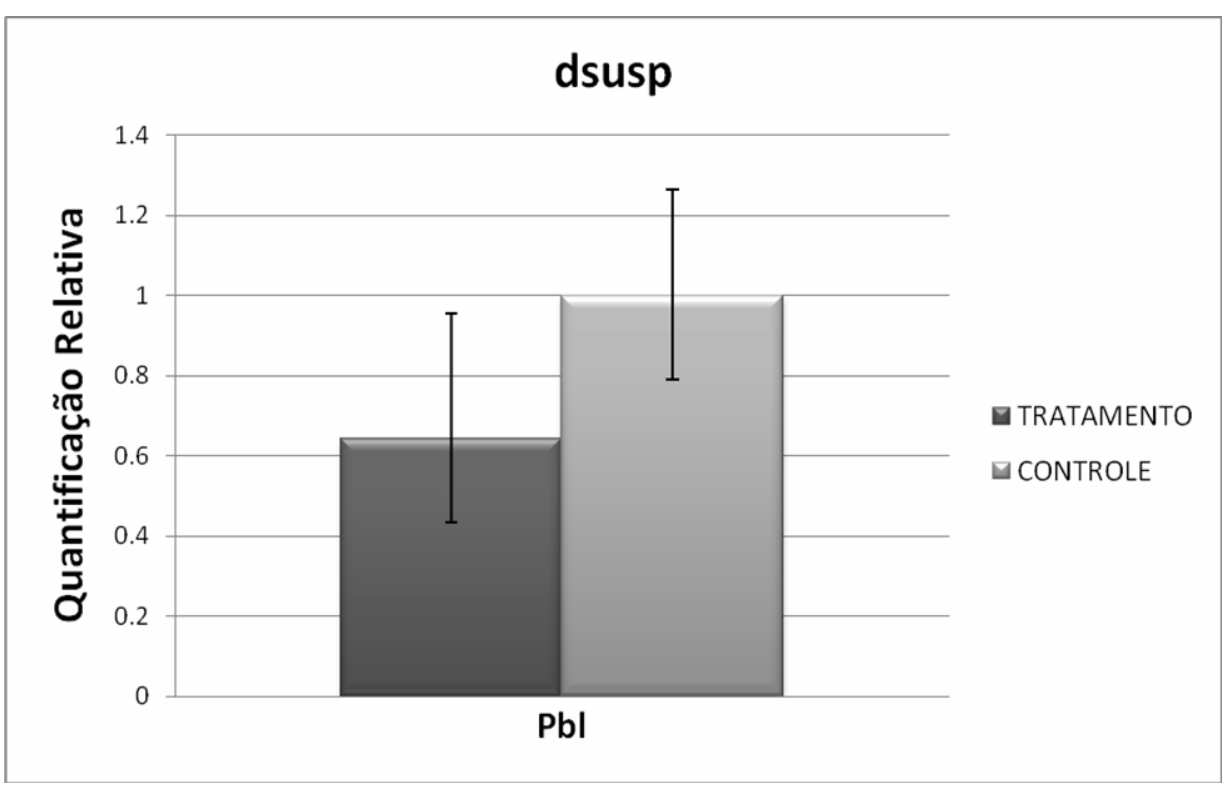

Figura 18: Quantificação relativa de mRNAs do gene codificador de ultraspiracle (usp) em larvas de operárias de Apis mellifera, em PP sem tratamento (Controle, $\mathrm{n}=3$ ) e tratadas no segundo estágio larval, L2 com 5,0 $\mu \mathrm{g}$ de dsusp $(\mathrm{n}=3)$ e em Pbl sem tratamento (Controle, $\mathrm{n}=3$ ) e tratadas no segundo estágio larval, L2 com 5,0 $\mu \mathrm{g}$ de dsusp $(\mathrm{n}=4)$. Os valores de expressão obtidos para o gene codificador de elFS-8 foram utilizados para normalização da expressão de usp. Os dados de cada grupo correspondem à média da expressão das amostras. As linhas representam o desvio padrão. A expressão relativa foi calculada de acordo com o que foi proposto por Livak \& Schmittgen (2001). Asteriscos indicam diferença estatística significativa de acordo com Teste MannWhitney $(\mathrm{p}<0,05)$ entre as amostas tratadas e controle. 


\subsection{4 esterase do hormônio juvenil - jhe}

Os indivíduos tratados com dsjhe apresentaram um ligeiro adiantamento no desenvolvimento em relação aos indivíduos controle. Deveriam, de acordo com o número de horas após a eclosão, estar em L5S1, mas já se encontravam em fase posterior, em L5S2 ou L5S3 (resultado não mostrado). As análises utilizando a média dos resultados obtidos para cada amostra controle $(n=4)$ e tratada $(n=4)$ mostraram uma queda média de 60\% nos níveis de expressão de jhe (Figura 19), estatisticamente significativa, segundo Teste Mann-Whitney $(\mathrm{p}<0,05)$.

Foram determinados também os níveis de transcritos de EcR-A, EcR-B, $c r c, R f a B p$ e usp nas amostras tratadas com dsjhe e controle. Observamos alterações relativas aos níveis de expressão para todos os genes estudados. Da mesma forma como foi visto para os níveis de expressão de $E c R$-A em amostras dscrc, os níveis deste gene também aumentaram em amostras dsRfaBp em relação ao controle (Figura 20). Os genes $R f a B p$ e crc também apresentaram aumento nos níveis de transcritos nas amostras tratadas em relação às amostras controle (Figura 20) e para $E c R$-B e $u s p$, o tratamento com dsjhe causou diminuição em seus níveis de transcrição em relação ao controle (Figura 20). Observamos diferença estatística significativa entre controle e tratamento com dsjhe para os genes estudados com exceção de $\operatorname{crc}$ e $E c R$-B (Teste Mann-Whitney, $\mathrm{p}<0,05$ ).

Foi feita uma comparação evidenciando o efeito do silenciamento por RNAi dos genes estudados sobre os níveis de expressão de seu respectivo gene alvo e dos demais genes testados. Esta comparação mostra o efeito do silenciamento em seu gene alvo e também nos demais genes testados em relação ao aumento ou diminuição nos níveis de expressão de cada gene, mostrando em que situação os níveis destes apresentaram aumento ou diminuição (Tabela 7). EcR-A apresenta aumento nos níveis de expressão para todos os tratamentos em que foi testado e jhe, contrariamente, mostra queda nos seus níveis de mRNA em todas. Podemos também observar um padrão contrário nos efeitos encontrados para $c r c$ e $E c R$-B, e para $R f a B p$ e usp. $c r c$ teve seus níveis diminuídos pelo tratamento com o seu respectivo dsRNA, e aumentados pelo tratamento com dsRfaBp e dsjhe, enquanto em EcRB observamos o oposto para os tratamentos citados (Tabela 7). A relação oposta encontradas para $R f a B p$ e usp é observada em seus níveis em relação aos tratamentos, $R f a B p$ apresenta diminuição em seus níveis de transcritos estimulada pelo tratamento com seu próprio dsRNA enquanto que este tratamento faz com que os níveis de usp aumentem. Já os tratamentos com dscrc e dsjhe estimulam a expressão de $u s p$ enquanto inibem a expressão de $R f a B p$. Os demais, como apresentado nos resultados anteriores e na tabela 7, mostram queda ou diminuição de acordo com o gene silenciado. 


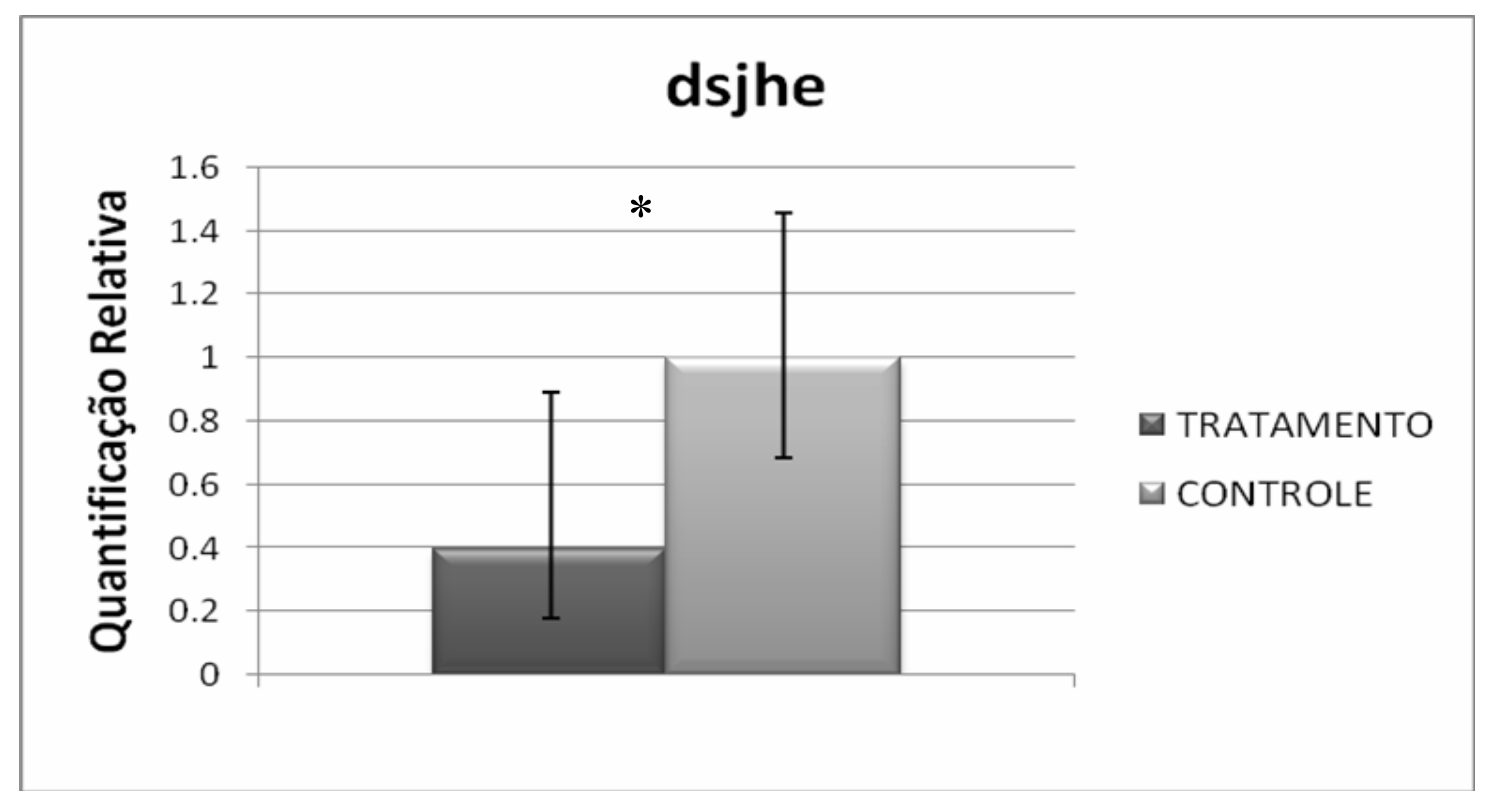

Figura 19: Quantificação relativa de mRNAs do gene codificador da esterase do hormônio juvenil (jhe) em larvas de operárias de Apis mellifera, no estágio de desenvolvimento L5-S2 ou L\%-S3 sem tratamento (Controle, $\mathrm{n}=4)$ e tratadas no segundo estágio larval, L2 com 5,0 $\mu \mathrm{g}$ de dsjhe $(\mathrm{n}=4)$. Os valores de expressão obtidos para o gene codificador de RP-49 foram utilizados para normalização da expressão de $j h e$. Os dados de cada grupo correspondem à expressão da média de amostras contendo um pool de 3 indivíduos cada, e as linhas representam o desvio padrão das amostras, obtido de acordo com o que foi proposto por Livak \& Schmittgen (2001). Asteriscos indicam diferença estatística significativa de acordo com Teste Mann-Whitney $(p<0,05)$ entre as amostas tratadas e controle. 

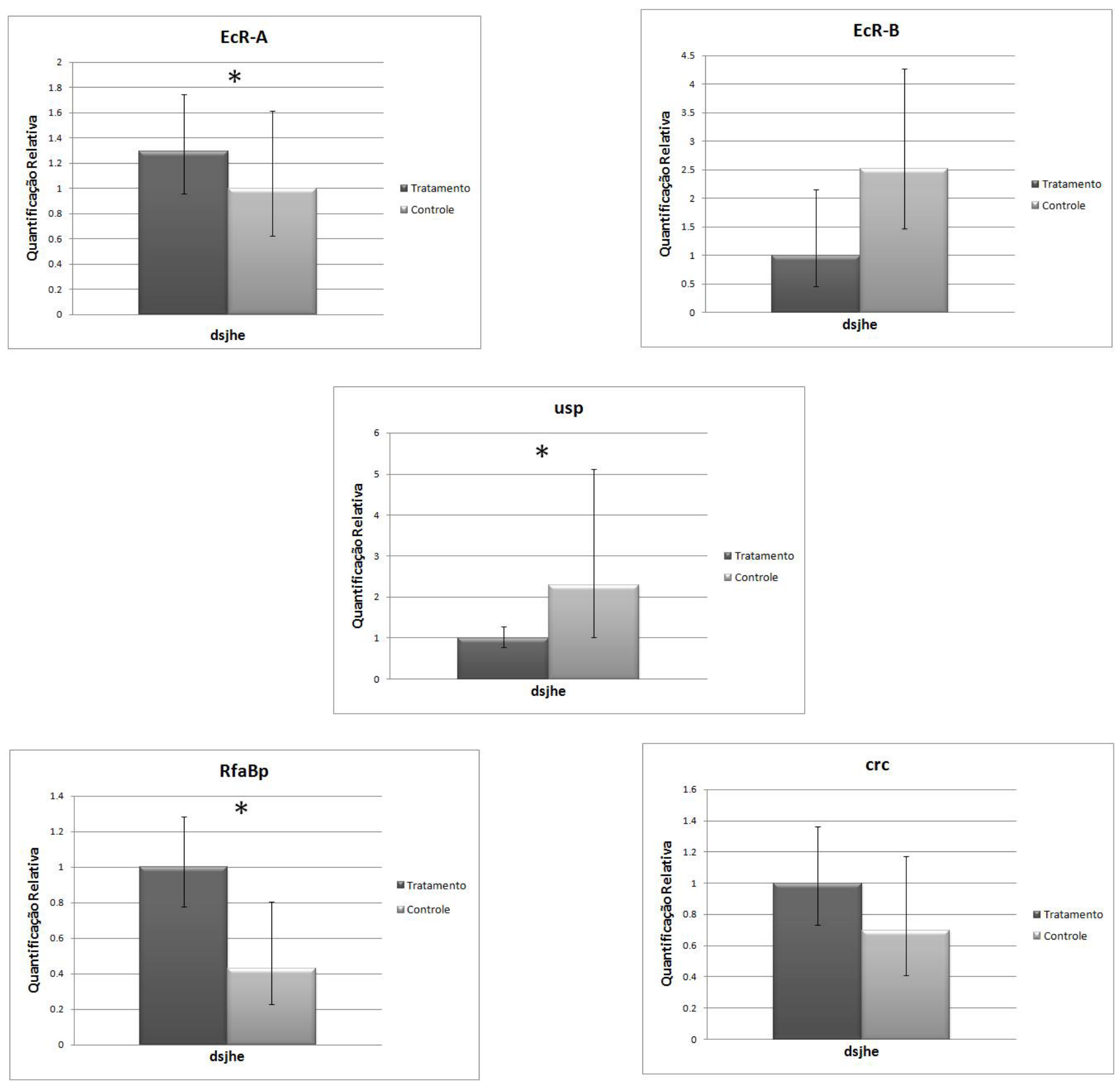

Figura 20: Quantificação relativa de mRNAs dos genes codificadores de $E c R$ variante A (EcR-A); $E c R$ variante $\mathrm{B}$ (EcR-B); ultraspiracle (usp); cryptocephal (crc) e retinoid- and fatty acid-binding protein (RfaBp); em amostras tratadas com 5,0 $\mu \mathrm{g}$ de dsjhe $(\mathrm{n}=4)$ e seus controles $(\mathrm{n}=4)$ para os quais nenhum dsRNA foi administrado. Os valores obtidos para o gene codificador de RP-49 foram utilizados para normalização. Os dados de cada grupo correspondem à expressão da média das amostras, e as linhas representam o desvio padrão das amostras, obtido de acordo com o que foi proposto por Livak \& Schmittgen (2001). Asteriscos representam diferença estatística significativa de acordo com Teste Mann-Whitney $(p<0,05)$ entre as amostas tratadas e controle. 
Tabela 7: Análise do efeito do silenciamento gênico por RNAi dos genes-alvos $c r c, R f a B p$ e jhe sobre a expressão de outros genes ( $c r c, R f a B p$, usp, jhe, EcR-A, EcR-B) por qPCR. (+) representa aumento nos níveis de expressão dos genes nas amostras silenciadas em relação ao controle. (-) representa queda nos níveis de expressão dos genes.

\begin{tabular}{|c|c|c|c|c|c|c|}
\hline \multirow{2}{*}{ GENE SILENCIADO } & \multicolumn{7}{|c|}{ GENE TESTADO } \\
\cline { 2 - 7 } & $c r c$ & $R f a B p$ & $u s p$ & $j h e$ & $E c R-A$ & $E c R-\mathrm{B}$ \\
\hline$c r c$ & - & + & - & - & + & + \\
\hline$R f a B p$ & + & - & + & - & + & - \\
\hline$j h e$ & + & + & - & - & + & - \\
\hline
\end{tabular}

\subsection{BUSCA POR microRNAs REGULADORES DE jhe}

Os resultados obtidos nos experimentos de expressão diferencial entre rainhas e operárias indicaram o gene codificador da esterase do hormônio juvenil, jhe, como preferencialmente expresso operárias, podendo exercer um importante papel na determinação de castas. Como o hormônio juvenil, alvo da ação da enzima JHE, desempenha papel fundamental no processo de determinação de castas, decidimos realizar estudos complementares. Estes estudos envolveram a predição moléculas possivelmente envolvidas na regulação deste gene, os microRNAs. Esta predição foi feita através de uma análise criteriosa da região 3' não traduzida (3' UTR) do jhe, que mostrou a presença de sítios de ligação para 22 microRNAs, possíveis reguladores deste gene (Tabela 8). 
Tabela 8: MicroRNAs sugeridos como possíveis reguladores do gene da esterase do hormônio juvenil (jhe GB15327) encontrados através de busca em banco de dados disponíveis utilizando o programa RNAhybrid e tendo como critério de inclusão: energia livre $\leq-15 \mathrm{Kcal} / \mathrm{mol}$, p-value $<0.05$ e complementaridade total da região seed (2-7). Em negrito miRNAs para os quais já existe função descrita na literatura.

\begin{tabular}{|c|c|c|}
\hline \multicolumn{3}{|c|}{ RNAhybrid } \\
\hline miRNA & GB & energia \\
\hline ame-miR-1 & & -16.8 \\
\hline ame-miR-12 & & -15.6 \\
\hline ame-miR-278 & & -17.9 \\
\hline ame-miR-8 & & -15.4 \\
\hline ame-let-7 & & -17.6 \\
\hline ame-miR-34 & & -19.7 \\
\hline ame-miR-263b & & -16.8 \\
\hline ame-miR-985 & & -16.6 \\
\hline ame-miR-989 & & -16.9 \\
\hline ame-miR-3752 & & -18.6 \\
\hline ame-miR-3772 & GB15327 & -19.2 \\
\hline ame-miR-3776 & & -17.8 \\
\hline ame-miR-3786 & & -16.6 \\
\hline ame-miR-3787 & & -15.1 \\
\hline ame-miR-3789 & & -17.7 \\
\hline ame-miR-3792 & & -19.5 \\
\hline ame-miR-3794 & & -15.4 \\
\hline ame-miR-3728 & & -16.5 \\
\hline ame-miR-3715 & & -15.4 \\
\hline ame-miR-3716a & & -15 \\
\hline ame-miR-3739 & & -17.5 \\
\hline ame-miR-3740 & & -16.2 \\
\hline
\end{tabular}




\subsection{VALIDAÇÃO DE miRNAs SUGERIDOS COMO REGULADORES DE jhe}

\subsubsection{ESTUDOS DE EXPRESSÃO DOS miRNAS EM RAINHAS E OPERÁRIAS}

A função canônica dos miRNAs é reduzir os níveis de tradução dos genes-alvos, ou seja, um controle pós-transcricional. Isso ocorre em decorrência do pareamento imperfeito do miRNA à região 3' não-traduzida do mRNA-alvo. A predição das interações miRNA-mRNA foi baseada na complementaridade da seed, que corresponde ao pareamento perfeito da extremidade $5^{\prime}$ de um miRNA ao alvo, ou seja, nas suas posições 1-8, 1-7, 2-8, e/ou 2-7. Os perfis dos miRNAs candidatos a reguladores de jhe (gene-alvo) foram avaliados em três diferentes pontos no desenvolvimento. Estes pontos correspondem aos maiores níveis de transcrição do gene jhe em operárias (L5F3), em rainhas (L5S2) e em uma fase em que os niveis eram basais para ambas $(\mathrm{Pb})$. Os resultados encontrados para cada miRNA estudado podem ser encontrados no Anexo 6. Em seguida, foi calculada a correlação entre estes perfis dos miRNAs candidatos e o perfil de expressão de $j$ he, tendo sido considerados como perfis antagônicos aqueles cuja correlação foi igual o menor que $-0.8(\mathrm{r} \leq-0.8)$. Três miRNAs apresentaram perfil antagônico em relação ao perfil de $j h e$ e provavelmente estão de acordo com o que foi encontrado na abordagem computacional. Assim, a presença de sítios de ligação para os miRNAs let-7, miR-263b e miR-989 na região 3' não-traduzida de jhe e os perfis de expressão destes miRNAs os apontam como fortes candidatos a reguladores do gene $j h e$. Além destes, o miR-2769 emergiu como forte candidato a regulador de $j$ he por apresentar perfil antagônico em rainhas e operárias $(r=-0.89$ e $r$ $=-0.91$, respectivamente) e por possivelmente estar associado à determinação de castas em $A$. mellifera, de acordo com Zayed, A. (comunicação pessoal). A Figura 21 mostra os perfis de expressão dos miRNAs ame-let-7, ame-miR-263b, ame-miR-989 e ame-miR-2796 e do gene-alvo $j$ he. 

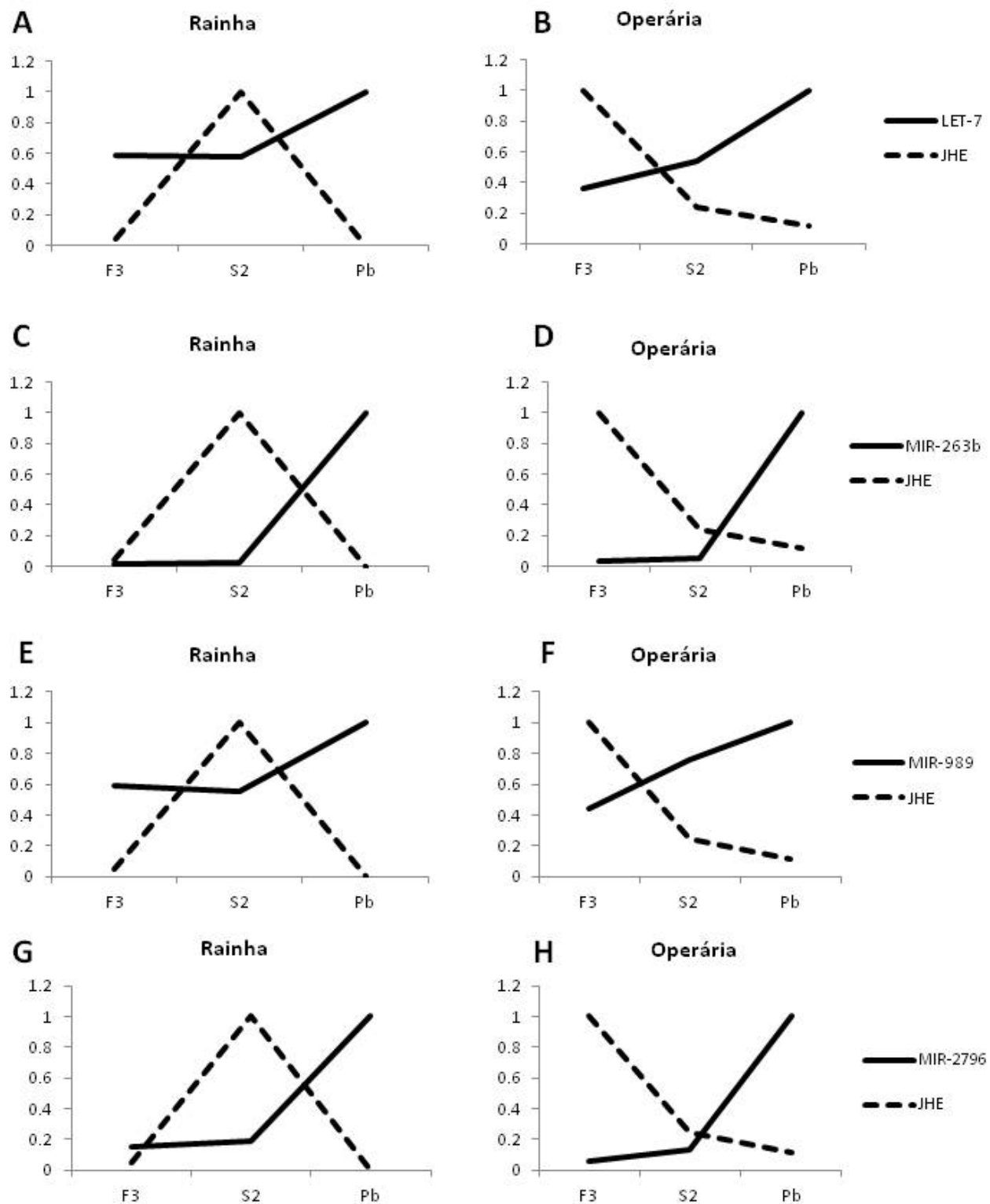

Figura 21: Perfis de expressão relativa do gene codificador da esterase do hormônio juvenil (JHE) e dos miRNAs candidatos a reguladores nas fases larvais L5F3 e L5S2 e pupal $\mathrm{Pb}$ de rainha e operária de $A$. mellifera. Os valores de expressão $\left(2^{\wedge} \mathrm{ddCT}\right)$ estão plotados no eixo $y$ e as fases do desenvolvimento no eixo $x$. (A) Perfil de expressão antagônico entre JHE e ame-let-7 em rainhas $(\mathrm{r}=-0.95)$. (B) Perfil de expressão antagônico entre JHE e ame-let-7 em operárias $(\mathrm{r}=-0.95)$. (C) Perfil de expressão antagônico entre JHE e ame-miR-263b em rainhas $(\mathrm{r}=-0.9)$. (D) Perfil de expressão antagônico entre JHE e ame-miR-263b em operárias $(\mathrm{r}=-0.83)$. (E) Perfil de expressão antagônico entre JHE e ame-miR-989 em rainhas ( $\mathrm{r}=-0.97)$. (F) Perfil de expressão antagônico entre JHE e ame-miR-989 em operárias ( $\mathrm{r}=-1)$. (G) Perfil de expressão antagônico entre JHE e ame$m i R-2796$ em rainhas $(\mathrm{r}=-0.89)$. $(\mathrm{H})$ Perfil de expressão antagônico entre JHE e ame-miR-2796 em operárias $(\mathrm{r}=$ $-0.91)$. 


\subsubsection{ESTUDOS DE EXPRESSÃO DOS miRNAS EM AMOSTRAS KNOCK-DOWN PARA jhe}

Como mencionado anteriormente, análises computacionais da região 3 ' UTR do gene codificador da esterase do hormônio juvenil, o jhe, sugeriram alguns miRNAs reguladores para este gene. Estudos anteriores utilizando interferência por RNA (RNAi) para jhe, mostraram queda nos níveis de expressão deste gene nas amostras tratadas em relação ao controle sem tratamento. As amostras tratadas foram utilizadas nesta etapa para avaliar a influência dos níveis de $j$ he na expressão dos seu possíveis reguladores. Os resultados mostraram aumento nos níveis de expressão de ame-let7, ame-miR-1, ame-miR-12, ame-mi-34, ame-miR-278 e ame-miR-989 nas amostras tratadas em relação ao controle (Figura 22). Contrariamente, o ame-miR-263b (Figura 22) mostrou queda nos níveis de expressão nas amostras tratadas com dsjhe, e para o ame-miR-8 e ame-miR-2796 os níveis encontrados são praticamente os mesmos para os dois grupos de amostras (Figura 22). Foi encontrada diferença estatística entre controle e tratamento para ame-miR-1, segundo teste Mann-Whitney $(\mathrm{p}<$ $0,05)$. 

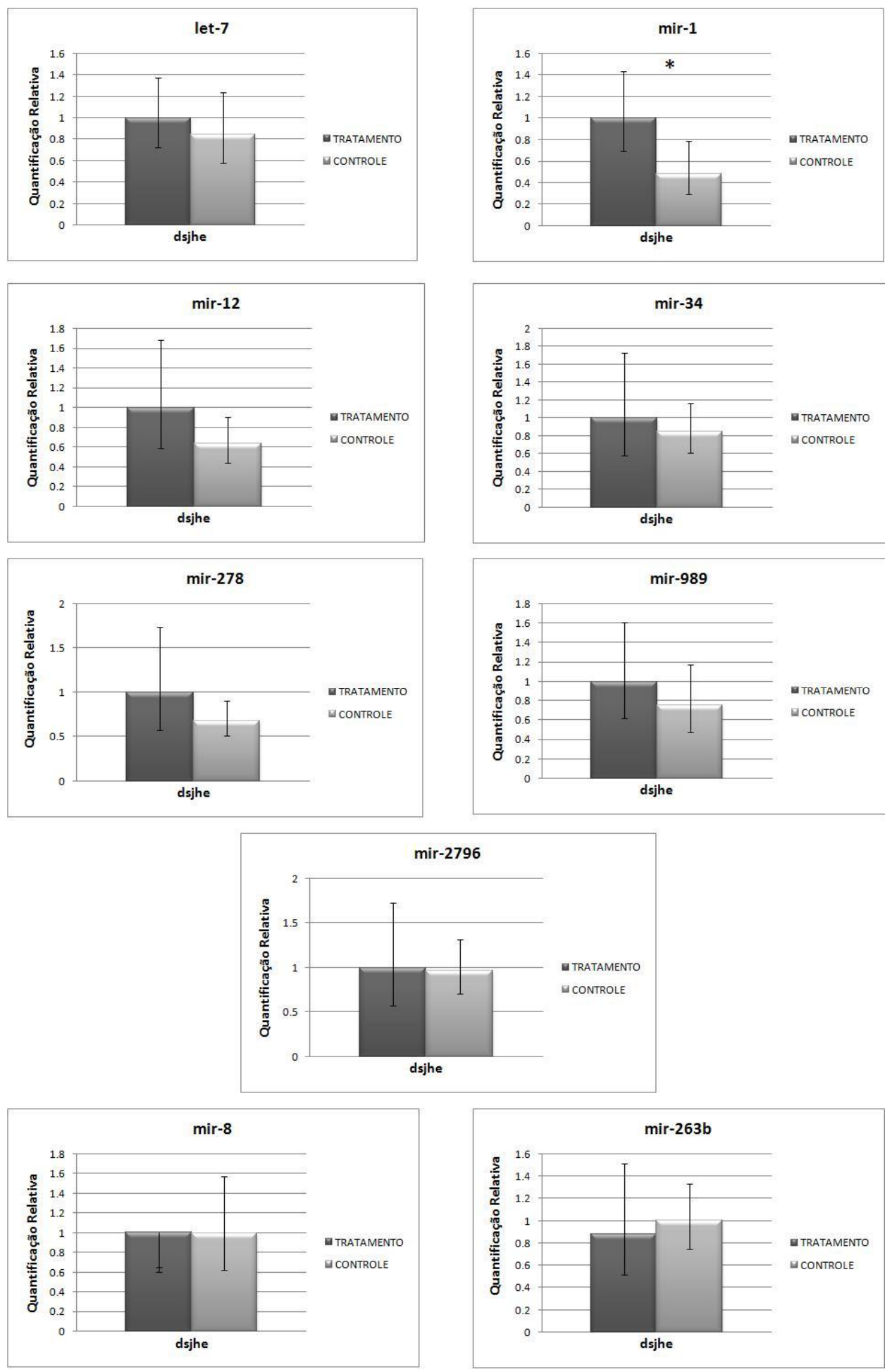

Figura 22: Quantificação relativa de microRNAs ame-let-7; ame-miR-1; ame-miR-12; ame-miR-34; ame-miR278; ame-miR-989; ame-miR-2796; ame-miR-8 e ame-miR-263b em amostra tratadas com dsjhe (n=4) e controle $(\mathrm{n}=4)$. Os valores obtidos para o pequeno RNA nuclear U6 foram utilizados para normalização. Os dados de cada grupo correspondem à expressão da média das amostras, e as linhas representam o desvio padrão das amostras, obtido de acordo com o que foi proposto por Livak \& Schmittgen (2001). Asteriscos representam diferença estatística significativa entre amostras tratadas com dsjhe e controle (Teste Mann-Whitney p < 0,05). 


\subsection{SEQUENCIAMENTO EM LARGA ESCALA DOS PEQUENOS RNAS}

\subsubsection{CARACTERIZAÇÃO DAS BIBLIOTECAS OBTIDAS ATRAVÉS DO SEQUENCIAMENTO DE PEQUENOS RNAS}

Visando um estudo mais aprofundado da regulação do gene codificador da esterase do hormônio juvenil, enviamos amostras resultantes do experimento de silenciamento de $j$ he (descrito na seção 4.4.4 dos RESULTADOS) para uma facility na Universidade da Carolina do Norte em Chapel Hill, EUA. Moléculas de RNAs pequenos (RNAs menores que $200 \mathrm{nt}$, faixa onde se encontram os microRNAs precursores ou maduros) foram isoladas de três amostras extraídas de indivíduos tratados com dsjhe e três amostras extraídas de indivíduos controles foram sequenciadas na plataforma Illumina. Cada amostra (grupo "tratamento" e "controle") foi formada por um pool de três operárias na fase L5-S, obtidas como descrito na seção 3.6.7.1. Os arquivos contendo o resultado do sequenciamento foram analisados para caracterizar as bibliotecas resultantes das seis amostras e identificar os miRNAs diferencialmente expressos entre os dois grupos amostrais.

Após a remoção dos adaptadores e filtragem das reads de baixa qualidade, foram consideradas para as etapas seguintes apenas as reads que apresentavam um comprimento maior ou igual a 10 bases. A Figura 23 mostra a distribuição do comprimento de reads para as bibliotecas "tratamento" e "controles". Ao comparar as distribuições encontradas para as bibliotecas "tratadas" e "controles", foram encontradas algumas diferenças. A proporção de reads que apresenta de 19 a 24 nt é em torno de $9 \%$ na bibliotecas "tratadas" e $25 \%$ nas bibliotecas "controle". O inverso foi encontrado para a faixa de 10 a $18 \mathrm{nt}$. Aproximadamente $68 \%$ das reads das bibliotecas "tratamento" e $6 \%$ das reads das bibliotecas "controle" apresentam de 10 a 18 nt.

As reads que compõem as bibliotecas foram mapeadas contra um banco de dados de sequências expressas. A análise desse mapeamento permitiu identificar quais tipos de transcritos compõem cada uma das bibliotecas. A Tabela 9 apresenta o número de reads de cada biblioteca e os valores de reads unicamente mapeadas e a Figura 24 apresenta a porcentagem de reads mapeadas em cada entidade genética que compõe o banco de dados. Novamente foram encontradas proporções diferentes entre as 
bibliotecas "tratamento" e "controle". As bibliotecas "controle" apresentam maior proporção de miRNAs (5\%) e de rRNA (47\%) em relação as bibliotecas "tratamento" (2\% e $17 \%$ para miRNA e rRNA, respectivamente). Além disso, as bibliotecas "tratamento" apresentam aproximadamente três vezes mais reads provenientes de genes codificadores (30\%) do que as bibliotecas "controle" $(9 \%)$.

\subsubsection{IDENTIFICAÇÃO DOS mIRNAS DIFERENCIALMENTE EXPRESSOS NAS BIBLIOTECAS “TRATAMENTO” E “CONTROLE”}

Após a caracterização das bibliotecas, foram selecionadas apenas as reads que mapearam em sequências de miRNAs de Apis mellifera. Assim, foram identificados os miRNAs expressos nas bibliotecas e a o cálculo da expressão digital foi obtida através da contagem do número de reads mapeadas em cada um dos miRNAs de A. mellifera. Essa contagem foi normalizada pelo tamanho das bibliotecas, de acordo com a normalização sugerida por Mortazavi et al. (2008).

Uma tabela relacionando a expressão digital de cada miRNA em cada biblioteca serviu de entrada para o pacote estatístico edgeR. O objetivo da análise foi identificar os miRNAs diferencialmente expressos nas bibliotecas "tratamento" e "controle". Foram identificados 14 miRNAs afetados pelo silenciamento de $j h e$ (Tabela 10). Os miRNAs ame-miR-3728, ame-miR-3727, ame-miR3759, ame-miR-3793, ame-miR-3720, ame-miR-3477 e ame-miR-316 apresentaram maior expressão nas bibliotecas "tratamento" e os miRNAs ame-miR-317, ame-miR-3719, ame-miR-996, ame-miR100, ame-miR-13b, ame-miR-306 e ame-miR-263b apresentaram menores níveis de expressão nas bibliotecas "tratamento". Dentre os 14 miRNAs diferencialmente expressos, quatro já foram descritos em outras espécies e as informações estão listadas na Tabela 11.

Com o objetivo de identificar os processos biológicos sob regulação dos miRNAs afetados pelo silenciamento da $j h e$, seguimos os seguintes passos. Foi realizada uma predição dos potenciais genes-alvo dos 14 miRNAs diferencialmente expressos nas bibliotecas "tratamento" e "controle". Foram encontradas 1.011 interações putativas entre os 14 miRNAs diferencialmente expressos e todos os genes preditos para A. mellifera. Em seguida, os ortólogos de D. melanogaster desses genes candidatos a alvo foram recuperados. Das 1.011 interações, 562 envolvem genes com ortólogos conhecidos em D. melanogaster. Esse passo que recupera os ortólogos da mosca-das-frutas é essencial 
para a identificação dos processos biológicos dos quais os genes candidatos a alvo fazem parte (usando os termos de GO), uma vez que essa associação ainda não foi estabelecida para as abelhas $A$. mellifera. As Tabelas 12 e 13 apresentam os processos biológicos associados aos genes candidatos a alvo dos miRNAs mais expressos e menos expressos nas bibliotecas "tratamento" em relação as “controle", respectivamente.

(A)

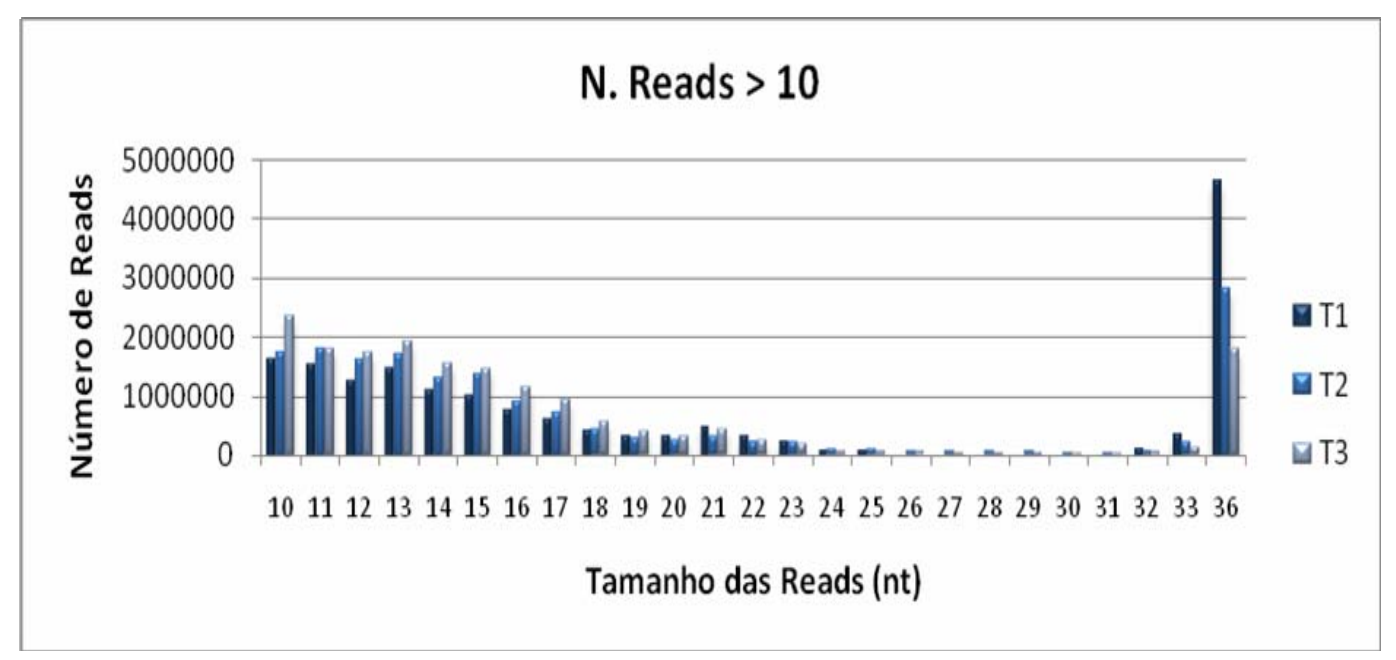

(B)

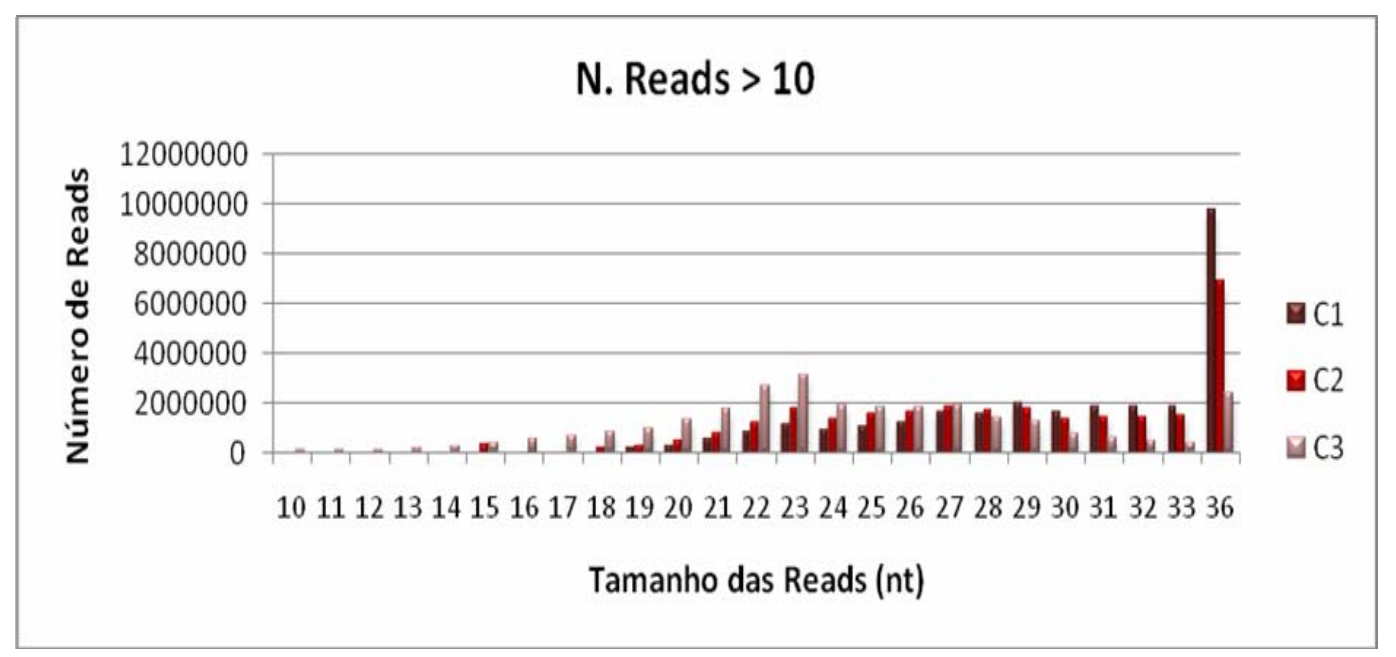

Figura 23: Número de reads por comprimento para cada uma das bibliotecas. (A) das amostras tratadas com dsRNA para o gene da esterase do hormônio juvenil (dsjhe) e (B) das amostras controle utilizadas nas análise para o tratamento com dsjhe. $\mathrm{C} 1$ : amostra controle número1; $\mathrm{C} 2$ : amostra controle número 2 ; $\mathrm{C} 3$ : amostra controle número 3; T1: amostra número 1 tratada com dsjhe; T2: amostra número2 tratada com dsjhe; T3: amostra número 3 tratada com dsjhe. 
Tabela 9: Número de reads geradas pelo sequenciamento em larga escala de amostras de operárias de $A$. mellifera tratadas com RNA de fita dupla para o gene da esterase do hormônio juvenil, jhe e amostras controle que não receberam nenhum dsRNA. T1, T2, T3: tratamentos 1, 2 e 3, respectivamente; C1, C2, C3: controles 1, 2 e 3 , respectivamente.

\begin{tabular}{|c|c|c|}
\hline AMOSTRA & $\begin{array}{c}\text { NÚMERO TOTAL } \\
\text { DE } R \text { EADS }\end{array}$ & $\begin{array}{c}\text { NÚUMRO DE } \\
\text { READS } \\
\text { MAPEADAS }\end{array}$ \\
\hline $\mathrm{T} 1$ & 24.472 .891 & 1.556 .321 \\
\hline $\mathrm{T} 2$ & 26.152 .456 & 1.448 .677 \\
\hline $\mathrm{T} 3$ & 26.332 .658 & 1.799 .089 \\
\hline $\mathrm{C} 1$ & 29.198 .697 & 2.881 .252 \\
\hline $\mathrm{C} 2$ & 28.431 .810 & 2.976 .428 \\
\hline $\mathrm{C} 3$ & 6.196 .478 & 3.026 .035 \\
\hline
\end{tabular}


A

Bibliotecas "Tratamento"

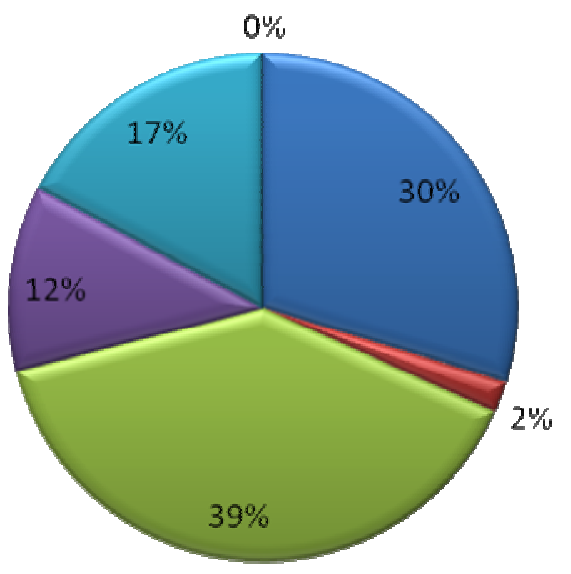

Genes Codificadores

$\square$ miRNA

$\checkmark$ noncode

- Patógenos

$\triangle$ rRNA

¿ tRNA

B

\section{Bibliotecas "Controle"}

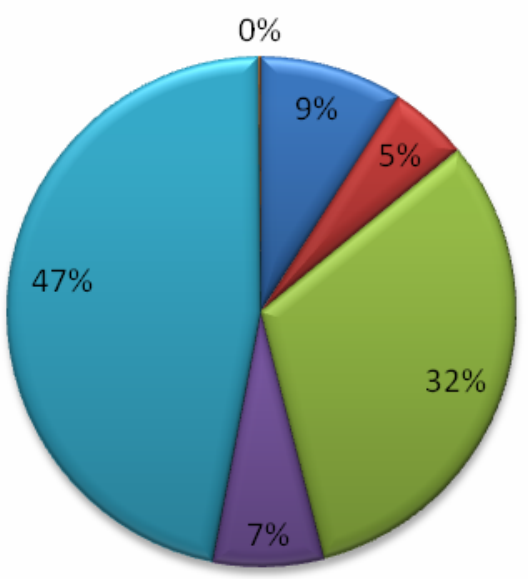

- Genes Codificadores

$\square$ miRNA

$\square$ noncode

- Patógenos

$\square \mathrm{rRNA}$

$\square \mathrm{tRNA}$

Figura 24: Gráficos mostrando a composição das bibliotecas de pequenos RNAs obtidas pelo sequenciamento em larga escala de amostras de operárias em fase L5-S silenciadas com dsjhe e operárias-controle. (A) Porcentagem da composição das bibliotecas "Tratamento". (B) Porcentagem da composição das bibliotecas "Controle". 
Tabela 10: MicroRNAs encontrados como diferencialmente expressos entre as amostras tratadas com dsRNA para o gene da esterase do hormônio juvenil (dsjhe) e controle de acordo com sequenciamento em larga escala (RNA-Seq). $\log F C$ ( $\log$ fold change): valores positivos indicam maior expressão nas bibliotecas "Tratamento" em relação as bibliotecas "Controle"; valores negativos indicam menor expressão nas bibliotecas "Tratamento" em relação as bibliotecas "Controle".

\begin{tabular}{|c|c|c|c|}
\hline miRNAs & logFC & PValue & FDR \\
\hline ame-miR-3728 & 5.64 & $2.07 \mathrm{E}-35$ & $3.48 \mathrm{E}-33$ \\
\hline ame-miR-3727 & 4.88 & $3.28 \mathrm{E}-33$ & $2.75 \mathrm{E}-31$ \\
\hline ame-miR-3759 & 3.94 & $7.82 \mathrm{E}-23$ & $4.38 \mathrm{E}-21$ \\
\hline ame-miR-3793 & 3.98 & $1.50 \mathrm{E}-17$ & $6.29 \mathrm{E}-16$ \\
\hline ame-miR-3720 & 2.07 & $6.57 \mathrm{E}-15$ & $2.21 \mathrm{E}-13$ \\
\hline ame-miR-3477 & 1.66 & $4.66 \mathrm{E}-09$ & $1.31 \mathrm{E}-07$ \\
\hline ame-miR-316 & 1.58 & $1.68 \mathrm{E}-07$ & $4.04 \mathrm{E}-06$ \\
\hline ame-miR-317 & -1.48 & $2.54 \mathrm{E}-07$ & $5.32 \mathrm{E}-06$ \\
\hline ame-miR-3719 & -1.23 & $3.73 \mathrm{E}-05$ & $6.95 \mathrm{E}-04$ \\
\hline ame-miR-996 & 1.01 & $6.54 \mathrm{E}-05$ & $1.10 \mathrm{E}-03$ \\
\hline ame-miR-100 & -1.94 & $1.76 \mathrm{E}-04$ & $2.69 \mathrm{E}-03$ \\
\hline ame-miR-13b & -0.82 & $6.82 \mathrm{E}-04$ & $9.54 \mathrm{E}-03$ \\
\hline ame-miR-306 & -0.76 & $9.70 \mathrm{E}-04$ & $1.25 \mathrm{E}-02$ \\
\hline ame-miR-263b & -1.22 & 9.71 & $1.00 \mathrm{E}-01$ \\
\hline
\end{tabular}

Tabela 11: MicroRNAs encontrados como diferencialmente expressos entre as amostras tratadas com dsRNA para o gene da esterase do hormônio juvenil (dsjhe) e controle de acordo com sequenciamento em larga escala (RNA-Seq), para os quais temos disponível na literatura função atribuída ou informação sobre níveis de expressão.

\begin{tabular}{|c|c|c|}
\hline miRNA & Função/Expressão & PubMed ID \\
\hline$m i R-100$ & $\begin{array}{c}\text { Envolvido na proliferação celular relacionada } \\
\text { ao câncer em mamíferos }\end{array}$ & $\begin{array}{c}21109969 ; 20421599 ; \\
19396866\end{array}$ \\
\hline$m i R-13 b$ & $\begin{array}{c}\text { Expresso em larvas Bombyx mori, } \\
\text { possivelmente envolvido com apoptose em } \\
\text { Drosophila }\end{array}$ & $18507836 ; 14691535$ \\
\hline$m i R-306$ & $\begin{array}{c}\text { Preferencialmente e abundantemente expresso } \\
\text { em adultos de Bombyx mori }\end{array}$ & 20089182 \\
\hline$m i R-263 b$ & $\begin{array}{c}\text { Envolvido na regulação negativa de apoptose } \\
\text { em Bombyx mori }\end{array}$ & $20563308 ; 20122259$ \\
\hline
\end{tabular}


Tabela 12: Processos biológicos, obtidos por análises de GO (Gene Ontology), nos quais os genes candidatos a alvo dos miRNAs regulados negativamente nas amostras tratadas com dsjhe $(\mathrm{n}=3)$ em relação às amostras controle $(n=3)$ estão relacionados, de acordo com o sequenciamento em larga escala.

\begin{tabular}{|c|c|c|}
\hline GO ID & Função Biológica & p-val \\
\hline 65007 & Regulação biológica & $1.19 \mathrm{E}-20$ \\
\hline 50789 & Regulação de processos biológicos & 2.77E-20 \\
\hline 50794 & Regulação de processos celulares & $1.61 \mathrm{E}-18$ \\
\hline 60255 & Regulação do processo metabólico de macromoléculas & $5.52 \mathrm{E}-16$ \\
\hline 19222 & Regulação do processo metabólico & $1.02 \mathrm{E}-15$ \\
\hline 80090 & Regulação do processo metabólico primário & $1.46 \mathrm{E}-15$ \\
\hline 10468 & Regulação da expressão gênica & $3.06 \mathrm{E}-15$ \\
\hline 48869 & Processo celular de desenvolvimento & $3.31 \mathrm{E}-15$ \\
\hline 9653 & Morfogênese anatômica de estruturas & $4.94 \mathrm{E}-15$ \\
\hline 35107 & Morfogênese de apêndices & $8.79 E-15$ \\
\hline 19219 & $\begin{array}{c}\text { Regulação do processo metabólico de nucleobase, nucleosídeo, nucleotídeo e ácido } \\
\text { nucléico }\end{array}$ & $9.27 \mathrm{E}-15$ \\
\hline 51171 & Regulação do processo metabólico de compostos nitrogenados & 1.04E-14 \\
\hline 48736 & Desenvolvimento de apêndices & $1.25 \mathrm{E}-14$ \\
\hline 31323 & Regulação do processo metabólico celular & $1.72 \mathrm{E}-14$ \\
\hline 48731 & Desenvolvimento de sistemas & $4.20 \mathrm{E}-14$ \\
\hline 35114 & Morfogênese de apêndices derivados de discos imaginais & $4.45 \mathrm{E}-14$ \\
\hline 30154 & Diferenciação celular & $5.46 \mathrm{E}-14$ \\
\hline 48737 & Desenvolvimento de apêndices derivados de discos imaginais & $6.26 \mathrm{E}-14$ \\
\hline 35120 & Morfogênese pós-embrionária de apêndices & 8.89E-14 \\
\hline 51252 & Regulação do processo metabólico de RNA & $1.78 \mathrm{E}-13$ \\
\hline
\end{tabular}


Tabela 13: Processos biológicos, obtidos por análises de GO (Gene Ontology), nos quais os genes candidatos a alvo dos miRNAs regulados positivamente nas amostras tratadas com dsjhe $(\mathrm{n}=3)$ em relação às amostras controle $(n=3)$ estão relacionados, de acordo com o sequenciamento em larga escala.

\begin{tabular}{|c|c|c|}
\hline GO ID & Função Biológica & p-val \\
\hline 50789 & Regulação de processos biológicos & 3.04E-08 \\
\hline 50794 & Regulação de processos celulares & $4.55 \mathrm{E}-08$ \\
\hline 51301 & Divisão celular & 2.27E-07 \\
\hline 32501 & Processos multicelulares do organismo & $2.92 \mathrm{E}-07$ \\
\hline 65007 & Regulação biológica & $3.12 \mathrm{E}-07$ \\
\hline 7275 & Desenvolvimento multicelular do organismo & $5.61 \mathrm{E}-07$ \\
\hline 48646 & Formação de estrutura anatômica envolvida na morfogênese & $5.76 \mathrm{E}-07$ \\
\hline 9790 & Desenvolvimento embrionário & $1.88 \mathrm{E}-06$ \\
\hline 7548 & Diferenciação do sexo & $1.95 \mathrm{E}-06$ \\
\hline 48477 & Oogenêse & 2.07E-06 \\
\hline 32502 & Processos de desenvolvimento & $2.27 \mathrm{E}-06$ \\
\hline 7292 & Geração do gameta feminino & $2.49 \mathrm{E}-06$ \\
\hline 35215 & Desenvolvimento do disco genital & $2.78 \mathrm{E}-06$ \\
\hline 7293 & Formação da câmara do ovo derivada do germário & $3.22 \mathrm{E}-06$ \\
\hline 8356 & Divisão celular assimétrica & $3.63 \mathrm{E}-06$ \\
\hline 7276 & Geração de gameta & $3.71 \mathrm{E}-06$ \\
\hline 3 & Reprodução & $4.32 \mathrm{E}-06$ \\
\hline 22414 & Processo reprodutivo & $4.32 \mathrm{E}-06$ \\
\hline 19953 & Reprodução sexual & $6.62 \mathrm{E}-06$ \\
\hline 32504 & Reprodução multicelular do organismo & $7.53 \mathrm{E}-06$ \\
\hline
\end{tabular}


Ao desenvolver este projeto demonstramos que inúmeros fatores ativados pela alteração da nutrição durante estágios iniciais do desenvolvimento larval coordenam a manifestação do dimorfismo de castas em A. mellifera, neste caso específico, a diferenciação em operárias. Nossos resultados permitiram associar a análise da expressão gênica diferencial com a determinação das castas em abelhas e propor uma rede de regulação destes eventos que, ainda que parcialmente, esclarecem aspectos importantes do dimorfismo das castas.

\subsection{GENES ESPECIALMENTE ENVOLVIDOS NA DETERMINAÇÃO DE CASTAS}

\subsection{1 cryptocephal - crc}

Assim como observado em outras espécies de insetos, por exemplo, em D. melanogaster (Hewes et al., 2000), crc é expresso durante todo o desenvolvimento pré-imaginal de A. mellifera. Os níveis de expressão de $c r c$ encontram-se baixos e muito semelhantes em rainhas e operárias até L3. A partir de L4, ocorrem diferenças nos níveis de expressão deste gene, os quais são mais elevados em operárias. O momento crítico da determinação de castas ocorre entre o terceiro e o quarto estágio larval (Goewie, 1978; Nijhout, 1994) o que pode estar relacionado com o fato de encontrarmos níveis de $\operatorname{crc}$ semelhantes em rainhas em operárias em fase anterior a este período. Após L4, o destino larval já está determinado e consequentemente cascatas gênicas distintas são disparadas de acordo com a casta que a larva irá se diferenciar. O gene crc apresenta um padrão de expressão específico de operárias, que é coincidente, em L4, com os dados descritos por Barchuk e colaboradores (2007). Verificamos também que em operárias esta expressão específica se estende até a vida adulta, provavelmente mantendo o estado de operária.

Os níveis de transcritos de crc parecem ter uma correspondência, tanto em rainhas como em operárias, com o primeiro pico de ecdisteróides encontrado em abelhas A. mellifera. Os títulos deste hormônio começam a se elevar no início do quinto estágio larval (L5F) e culminam em L5S2 em ambas as castas (Feldlaufer et al., 1985; Rachinsky et al., 1990). Durante este período, os níveis de crc começam a se elevar em rainhas e operárias, embora não sejam estes os valores máximos em cada 
casta. A partir daí, não é possível estabelecer uma relação clara entre os níveis de expressão deste e os títulos de ecdisteróides, pois durante os maiores níveis de expressão de $\operatorname{crc}$ nas castas (fase PP2 em rainhas e PP3 em operárias), encontram-se os níveis mais baixos de ecdisteróides (Feldlaufer et al., 1985; Rachinsky et al., 1990, Zufelato et al., 2000). Nestas fases, também se observam baixos títulos de HJ (Rembold, 1987; Rachinsky et al., 1990) o que pode estar contribuindo, juntamente com os títulos baixos de ecdisteróides, para o incremento nos níveis de transcrição de $c r c$. Os títulos de ecdisteróides após as fases PP2 e PP3 aumentam, atingindo seu máximo em Pdp. A partir de Pb os títulos destes hormônios começam a cair e permanecem relativamente baixos até o final do estágio pupal (Rembold, 1987). De maneira oposta, os níveis de crc começam cair gradativamente a partir de PP, atingindo um mínimo em Pdp e em seguida, subindo novamente para atingir novos picos de expressão em rainhas Pbd e operárias recém-emergidas (RN). A partir destas informações podemos sugerir que os ecdisteróides atuam de maneira diferente dependendo da fase de desenvolvimento em que as abelhas se encontram. Entre as fases L4 e L5S, os ecdisteróides atuam estimulando a transcrição de $\operatorname{crc}$ e a partir de PP agem de maneira oposta, indicando que estes hormônios provavelmente não atuam diretamente sobre a transcrição de $c r c$, como poderíamos esperar, já que este gene está envolvido na muda e metamorfose (Hewes et al., 2000), mas provavelmente em genes iniciais (early genes) e genes tardios (late genes) da cascata de expressão gênica estimulada por estes hormônios (Burtis et al. 1990; Segraves \& Hogness 1990; DiBello et al. 1991) que irão de alguma forma alterar os níveis de expressão de $c r c$, dependendo da fase do desenvolvimento.

Os principais picos de expressão deste gene encontram-se nos estágios pré-metamórficos, o que constitui uma indicação, que assim como em Drosophila, ele atua nos processos de muda e metamorfose (Hewes et al., 2000). Podemos observar que o pico de expressão mais importante encontrado em rainhas é adiantado em relação ao maior pico de expressão encontrado em operárias, isto pode estar relacionado ao fato de que rainhas e operárias apresentam diferenças no timing do desenvolvimento (Michelette \& Soares, 1993). Adicionalmente, os níveis alcançados pelo pico de expressão de $c r c$ em operárias são bem mais elevados que aqueles observados para o correspondente em rainhas. Além disto, a diferença estatística encontrada na maioria das fases estudadas, quando se comparam os níveis de transcritos deste gene entre as castas, fornece mais uma forte indicação do 
importante envolvimento deste gene no processo de desenvolvimento das castas em A. mellifera, como proposto por Barchuk et al. (2007).

\subsection{2 retinoid-and fatty acid-binding protein - RfaBp}

Semelhante ao que foi observado para o gene $c r c$, os perfis de expressão encontrado para $R f a B p$, em rainhas e operárias de $A$. mellifera, apresentam níveis praticamente basais desde embrião (ovo) até o terceiro estágio larval (L3). A partir de L3 até L5F3 os níveis de expressão do gene aumentam gradualmente em ambas as castas, atingindo o maior pico de expressão em operárias L5F3, dado concordante com o descrito por Guidugli-Lazzarini (2006), e em rainhas L5S3. A proteína RFABP tem a capacidade de transportar lipídios (Van Heusden \& Law, 1989) inclusive o HJ (Trowell, 1992; Engelmann \& Mala, 2005), portanto o gene codificador desta proteína pode estar atuando como um gene tardio na cascata de expressão gênica desencadeada pelo hormônio. Em rainhas os níveis de HJ e ecdisteróides encontrados na fase L5S3 são comparativamente elevados, sugerindo uma ação sinérgica sobre os níveis de expressão de $R f a B p$. A ação dos ecdisteróides aumentando os níveis de expressão do gene $l p$, já foi descrita em Aedes aegypti (Sun et al., 2000).

Em Drosophila, o gene $R f a B g$, homólogo ao RfaBp de A. mellifera, apresenta semelhanças com os genes codificadores das proteínas lipoforina, apolipoforina e vitelogenina (Kutty et al., 1996). A vitelogenina, uma importante proteína da reprodução, inclusive em A. mellifera, requer um pulso de HJ, juntamente com declínio nos níveis de ecdisteróides para sua transcrição (Shu et al., 1997; Barchuk et al., 2002). De forma semelhante à vitelogenina, a expressão do gene $R f a B p$ durante a fase L5S3 em rainhas, pode constituir um importante fator que contribuirá para a reprodução, um dos principais processos que distinguem rainhas de operárias de abelhas A. mellifera (Wilson, 1971; Michener, 1974).

Nota-se que os principais picos de expressão de $R f a B p$, nas duas castas, ocorrem em um período pré-metamórfico. A metamorfose em insetos ocorre através de profundas alterações morfológicas e fisiológicas, que geralmente influenciam o conteúdo protéico encontrado na hemolinfa. Durante a fase larval, proteínas de estocagem são acumuladas na hemolinfa (Shipman et al., 1987) e em seguida estocadas para serem utilizadas posteriormente na produção de outras proteínas próprias de adultos 
(Levenbook \& Bauer, 1984). Desta forma, como sugerido por Guidugli-Lazzarini (2006), altos níveis de $R f a B p$ em L5F3 (em operárias) e L5S2 (em rainhas) podem indicar um envolvimento deste gene no fornecimento de nutrientes para a fase seguinte, atuando no transporte de lipídios ou como fonte destes compostos.

Observamos semelhança entre os perfis de $R f a B p$ de rainhas e operárias, mas podemos notar o adiantamento do principal pico de expressão do gene em operárias, assim como níveis significativamente mais elevados nesta casta em fases posteriores ao maior pico de expressão do gene encontrado em rainhas. Isto provavelmente se deve a diferentes fatores determinados em fase anterior, principalmente em razão da alimentação diferencial. Em operárias de $A$. mellifera adultas, a ingestão de alimentos com composição protéica distinta promove diferenças tanto na transcrição quanto na tradução de $R f a B p$ (Cunha et al., 2005). Assim podemos sugerir que a alimentação diferencial de rainhas e operárias durante o período larval pode ser capaz de determinar diferenças na expressão gênica que determinam o destino larval e que podem perdurar por toda a vida da abelha.

\subsection{3 ultraspiracle - usp}

Os perfis de usp encontrados em rainhas e operárias mostram grande semelhança, exceto durante parte do quinto estágio larval e final da fase pré-pupal. A partir de L5F2 até L5S1, os níveis deste gene são significativamente mais elevados em operárias que em rainhas. Isto pode refletir a passagem dos indivíduos pelo período crítico da determinação de castas (Goewie, 1978; Nijhout, 1994), após o qual cascatas de expressão gênica distintas são estimuladas nas diferentes castas (Barchuk, et al., 2007). Assim como ocorre com a expressão de crc, os níveis de usp durante o quinto estágio larval, tanto em rainhas quanto em operárias, parecem apresentar correspondência com o primeiro pico de ecdisteróides encontrado em $A$. mellifera. O mais importante pico de expressão de usp é encontrado em operárias PP3 e importantes níveis deste gene são encontrado em rainhas nas fases L5S2 e PP2. Os níveis de usp encontrados em operárias PP3 podem estar relacionados com picos anteriores dos títulos de ecdisteróides e HJ. O que pode sugerir que pulsos destes hormônios, essenciais para a muda e metamorfose (Nijhout, 1994; Riddiford, 1994; Lan et al., 1999), são também requeridos para um aumento na expressão do gene durante esta fase pré-metamórfica, em razão do 
papel fundamental exercido por este gene na integração de múltiplos caminhos de sinalização (Hall \&Thummel, 1998; Sasorith et al., 2002). Como usp provavelmente atua como receptor dos dois hormônios morfogenéticos (Yao et al., 1993; Xu et al., 2002; Barchuk et al., 2004; Iwema et al., 2007), podemos sugerir que o mesmo pode agir como um gene tardio nas diferentes redes de expressão gênica estimulada por eles. A diferença encontrada entre rainhas e operárias em relação aos níveis e à fase em que ocorrem os maiores níveis de transcrição de $u s p$ pode estar relacionada aos diferentes títulos de HJ apresentado por ambas e também pode ser constituída por diferentes fatores relacionados à expressão gênica diferencial determinada no período crítico de determinação de castas. Após PP2 em rainhas e PP3 em operárias, os níveis de expressão do gene sofrem uma queda e voltam a subir no final do estágio pupal em ambas, em uma proporção semelhante, o que mais uma vez reflete sua função essencial no desenvolvimento e metamorfose em insetos (Sasorith et al., 2002). Esta expressão é condizente com sua função como parceiro heterodimérico no receptor de ecdisona (Oro et al., 1990; Yao et al., 1992, 1993). Os níveis de usp em rainhas e operárias, em queda desde o início da fase pupal, começam a se elevar no final desta fase, mais uma vez em um período pré-metamórfico, indicando novamente seu papel essencial neste processo. Níveis elevados de usp no final do estágio pupal foram também observados Melipona scutellaris (Teles et al., 2007).

Coincidentemente, em operárias o principal pico de expressão de usp ocorre na mesma fase de desenvolvimento daquele encontrado para $c r c$, e os níveis de ambos nas fases subsequentes são correspondentes. Foram encontrados na sequência de $c r c$ motivos de ligação a usp, sugerindo uma possível relação entre estes genes, com usp atuando na ativação da transcrição de crc (Barchuk et al., 2007), fato corroborado pela semelhança entre seus níveis de expressão. O que pode indicar a participação destes em uma rede de expressão gênica que favoreceria o desenvolvimento de operárias, visto que, mais claramente em $c r c$, os níveis apresentados pelas castas são significativamente distintos principalmente nas fases posteriores ao período crítico de determinação de castas.

\subsection{4 esterase do hormônio juvenil - jhe}

O perfil de expressão de $j$ he durante o desenvolvimento de rainhas e operárias de A. mellifera apresenta níveis praticamente basais durante a maior parte do desenvolvimento pós-embrionário, exceto 
pelo período entre o início do quinto estágio larval e o início da fase pré-pupal. Em operárias, os níveis de transcritos de jhe são baixos desde a fase embrionária até L4, quando começam a se elevar, resultado observado também por outros autores (Mackert et al., 2008). Coincidentemente, é nesta fase que, após um pequeno pulso, os níveis de HJ começam a cair nesta casta (Rembold, 1987; Bloch et al., 2002; Elekonich et al. 2003). Podemos então relacionar esta queda nos títulos de HJ ao aumento nos níveis de expressão do gene codificador da principal enzima de degradação deste hormônio, possivelmente estimulado por este pequeno pulso de HJ. Os níveis de transcritos de jhe continuam em ascensão em operárias até o final da fase L5F, quando atingem seus maiores níveis em F3. Após este estágio, começam a diminuir, voltando a níveis basais a partir de PP1, resultado também encontrado por outros autores (Mackert et al., 2008) e em outras espécies como Aedes aegypti (Bai et al., 2007), Choristoneura fumiferana (Feng et al., 1999) e Bombyx mori (Hirai et al. 2002). Durante o período em que os níveis de expressão de jhe são elevados em operárias, podemos sugerir que os mesmos estejam inibindo a ação do HJ, que se encontra em níveis baixos nesta casta (Rembold, 1987; Kimura \& Truman, 1990; Schmidt-Capella \& Hartfelder, 1998, 2002). De acordo com dados disponíveis na literatura, podemos também sugerir uma relação inversa entre os títulos de HJ (Rembold, 1987; Elekonich et al., 2003) e sua principal enzima de degradação, a JHE, durante o período acima descrito e, além disto, os níveis baixos a partir de PP1 parecem permitir um aumento nos níveis de HJ encontrado no estágio pré-pupal (Rembold, 1987; Elekonich et al., 2003). Durante o estágio pupal, operárias apresentam níveis basais de jhe. Nesta fase é sugerido que os corpora allata, órgãos de síntese do HJ, cessam a produção deste hormônio (Rachinsky et al., 1990) o que pode ser observado nos resultados encontrados neste trabalho para os níveis de expressão da enzima metil-farnesoato-epoxidase (MFE) em rainhas e operárias em $\mathrm{Pb}$, portanto o produto de jhe não seria necessário nesta fase do desenvolvimento, já que o período crítico de determinação de castas já aconteceu e, além disto, a próxima muda que o inseto irá sofrer é metamórfica, ou seja controlada pelos ecdisteróides. Padrões semelhantes de expressão de jhe, com níveis basais nos estágios pré-pupal e pupal, foram também encontrados em Bombyx mori (Kinjoh et al., 2007). Ainda em operárias, no final do estágio pupal, os níveis de transcritos $j h e$ começam a se elevar e apresentam um pequeno pico de expressão, embora não tão elevado quanto aquele encontrado em L5F3, sendo coincidente com um pequeno e rápido aumento nos níveis de HJ. Esta 
alteração hormonal ainda não está totalmente esclarecida, mas indica que HJ deve ser removido neste momento nesta casta, o que não ocorre em rainhas.

Em rainhas podemos observar níveis de expressão baixos para jhe desde a fase embrionária até o final do $5^{\circ}$ estágio larval, em L5S1. Em L5S2 há um aumento significativo nos níveis de expressão deste gene, que atingem seu máximo durante esta fase, em que o HJ já desempenhou parte do seu papel, disparando cascatas de expressão gênicas responsáveis pelas características próprias de rainhas (Barchuk et al., 2007), além das mudanças morfológica ocasionadas por este hormônio (Rembold, 1987; Kimura \& Truman, 1990) entre elas a manutenção do número de ovaríolos (Schmidt-Capella \& Hartfelder, 1998, 2002). Após L5S2, a quantidade de transcritos jhe cai e atinge novamente níveis basais em PP2, mantendo-se assim até a emergência do adulto. Nesta casta, os maiores títulos de HJ são observados entre L3 e L4 (Rachinsky et al., 1990; Bloch et al., 2002; Elekonich et al.,2003), que como descrito anteriormente tem sua síntese estimulada pelo sistema insulina/IGF/TOR/Egfr iniciado, por sua vez, pelo estímulo nutricional diferencial (Colombani et al., 2003; Oldham \& Hafen, 2003; Barchuk et al., 2007; Patel et al., 2007; Kamakura, 2011). Altos títulos de HJ (Bloch et al., 2002; Elekonich et al., 2003) juntamente com a baixa expressão de $j$ he observada neste trabalho, sugerem que os níveis de síntese deste hormônio, realizada por outras enzimas (Goldstein \& Brown, 1990; Bellés et al., 2005), devem estar verdadeiramente elevados, determinando que os indivíduos se tornem rainhas, quando apresentam tal situação. De acordo com resultados encontrados, vimos que a enzima FME, a última no processo de síntese de HJ, apresenta níveis significativamente mais altos em rainhas nas fases em que foi estudada, constituindo mais uma indicação de que os níveis de HJ, fundamentais na determinação de castas, são determinados tanto pela sua síntese como pela sua degradação. Como mencionado acima, o pico de expressão de jhe em rainhas é encontrado em L5S2, fase em que os títulos de HJ encontram-se elevados, mas não na mesma proporção em que são encontrados em L3 (Bloch et al., 2002; Elekonich et al., 2003), sugerindo, adicionalmente,que o fator responsável por estes níveis seja provavelmente sua degradação pela enzima específica, a JHE. O que podemos concluir após análise destes resultados é que a degradação do hormônio juvenil pela sua enzima específica desempenha um papel tão importante quanto sua síntese e que um balanço entre eles em momentos precisos do desenvolvimento irá culminar na determinação de castas em A. mellifera, 
sugerindo, portanto, que as enzimas envolvidas no balanço dos níveis de HJ, sejam também importantes neste processo.

Podemos concluir que a expressão individual destes genes é coerente com o papel atribuído a eles no processo de determinação e desenvolvimento das castas de A. mellifera.

\subsection{EXPRESSÃO GÊNICA GLOBAL NAS DIFERENTES CASTAS DE ABELHAS Apis mellifera}

Muitos insetos apresentam polifenismo ou morfologias alternativas que são fundamentadas na expressão gênica diferencial ao invés de polimorfismo genético. Rainhas e operárias, as formas alternativas de fêmeas de $A$. mellifera, representam um dos exemplos mais conhecidos de polifenismo (Evans \&Wheeler, 1999). Mas, apesar dos grandes esforços, ainda há muito a se descobrir sobre os mecanismos moleculares responsáveis por este processo.

A determinação de castas em $A$. mellifera envolve ativação específica de genes em operárias, assim como em rainhas. Além disto, há um maior número de genes preferencialmente expressos em operárias durante a fase larval L4 em relação ao que foi encontrado para rainhas (Evans \&Wheeler, 1999). No entanto, este resultado difere do que foi encontrado em outro estudo, no qual foi observado maior número de genes preferencialmente expressos em rainhas na fase L4 (Barchuk et al., 2007). Tal fato pode estar relacionado com a utilização de microarranjos com número reduzido de genes, por estes últimos autores, mas mesmo assim os resultados aqui obtido com relação aos genes diferencialmente expressos durante a determinação de castas apresentam semelhanças com aqueles obtidos por Barchuk et al. (2007). Entre os genes diferencialmente expressos entre as castas, podemos destacar 21 genes em comum, onze preferencialmente expressos em operárias, oito preferencialmente expressos em rainhas e dois que são preferencialmente expressos em uma das duas castas de acordo com o trabalho em questão (ver Anexo7). Sendo que, vários destes genes exercem funções biológicas importantes durante o desenvolvimento de rainhas e operárias em A. mellifera, como neurogênese (Witthöft, 19967; Barchuk et al., 2007), regulação da apoptose (Schmidt-Capella \& Hartfelder, 1998; 2002), regulação da via de insulina (Patel et al., 2007). Isto reforça a ideia de cascatas gênicas 
diferenciais determinantes do destino larval, pois conjuntamente os resultados apontam diferenças entre as castas com relação aos níveis de expressão de genes específicos.

Análises de Gene Ontology (GO) mostraram que os genes diferencialmente expressos encontrados nos microarrays pertencem a várias categorias de processos biológicos. Sendo que os genes preferencialmente expressos em operárias estão mais representados nas seguintes categorias: Resposta imune, Óxido-redução, crescimento e proliferação celular (epidermal growth factor - egf), Homeostase, Morte celular, Processos de desenvolvimento, Metamorfose, Neurogênese. Os genes preferencialmente expressos em rainhas estão envolvidos principalmente na Respiração celular, Morfogênese, Oxidação Organização e modificação da cromatina, Adesão celular e Localização celular. Foram encontradas ainda categorias que evidenciam processos biológicos compartilhados tanto por rainhas quanto por operárias, entre elas podemos citar: Reprodução, Regulação da biossíntese, Regulação da transcrição e Transporte celular, o que não significa que elas compartilham genes diferencialmente expressos, mas sim que diferentes genes encontrados em cada uma das castas participam do mesmo processo biológico, ocasionando diferenças em relação a uma mesma característica.

Como mencionado, os genes preferencialmente expressos em operárias podem ser enquadrados em várias categorias de processos biológicos, mas em sua maioria eles pertencem a categorias relacionadas à resposta imune. Estudos demonstraram que abelhas em segundo estágio larval são mais suscetíveis à infecção que abelhas em fases posteriores sugerindo assim, que elas se tornam progressivamente mais resistentes com o tempo. Provavelmente, em razão do aumento da presença de fatores relacionados ao sistema imune, principalmente o sistema inato, como por exemplo, a lisozima e peptídeos antimicrobianos (Chan et al., 2009). Estes autores também sugerem que em abelhas a imunidade social é favorecida, pelo fato de que elas expressam menos genes relacionados à resposta imune que insetos solitários (conceito que poderá ser alterado no processo de re-anotação do genoma de A. mellifera). Isto pode em parte explicar a expressão preferencial de genes relacionado com este processo em operárias, que formam a maioria quase absoluta de indivíduos numa colônia.

Entre os demais processos biológicos relacionados aos genes preferencialmente em operárias podemos destacar a apoptose. Durante a determinação de operárias, o processo de apoptose ocorre principalmente nos ovários (Schmidt Capela \& Hartfelder, 2002), importante órgão que assinala uma 
das diferenças entre rainhas e operárias. Outro processo biológico, a neurogênese, é de crucial importância no desenvolvimento das operárias, visto que estas necessitam desenvolver habilidades de memória e aprendizagem. O desenvolvimento de tais habilidades está estreitamente relacionado a uma estrutura cerebral altamente desenvolvida, os corpos cogumelares (mushroom bodies - MB), que não apresentam tal nível de desenvolvimento em rainhas (Takeuchi et al., 2002; Malun et al., 2002).

Inesperadamente, dentre os processos biológicos, as categorias mais representativas em operárias estão relacionadas com o crescimento, tamanho celular e egf.Genes envolvidos com crescimento (genes fisiometabólicos) foram anteriormente descritos como preferencialmente expressos em rainhas (Barchuk et al., 2007). As rainhas são visivelmente maiores que as operárias principalmente na região abdominal, por apresentar os ovários altamente desenvolvidos. Além disto, Kamakura (2011) afirma que a royalactin, em A. mellifera, exerce efeito semelhante ao egf, lembrando que royalactin é a principal efetora no processo de desenvolvimento de rainhas.

A análise global da expressão gênica em ambas as castas de abelhas A. mellifera sugere a existência de redes próprias implicadas no desenvolvimento de rainhas e operárias. Como vimos o número de genes preferencialmente expressos em operárias é quase duas vezes maior do que em rainhas, dado que indica a existência de redes gênicas mais complexas na determinação da casta operária como sugerido por outros autores (Barchuk et al., 2007) e também a presença não apenas de um único gene, mais sim de um grupo de genes, como principais corresponsáveis pelo processo de determinação de castas em A. mellifera.

\subsection{EFEITOS DO NOCAUTE DOS GENES ESPECIALMENTE ENVOLVIDOS NA DETERMINAÇÃO DE CASTAS SOBRE DIFERENTES PROCESSOS BIOLÓGICOS}

\subsection{1 cryptocephal - crc}

O tratamento com RNA de fita dupla para o gene cryptocephal em experimentos de interferência por RNA em abelhas mostrou apenas uma discreta diminuição nos níveis do gene alvo. Esta discreta diminuição $(20 \%)$ dos transcritos de $\operatorname{crc}$ pode estar relacionada com o tempo entre o 
tratamento (L2) e a coleta dos indivíduos (L5S1), uma vez que pode ter havido uma queda significativa nos níveis de transcritos de crc logo após o tratamento que de alguma forma foi restabelecido posteriormente. Além disto, $\operatorname{crc}$ tem função nos processos de eversão da cabeça (Fristrom, 1965) e desenvolvimento de pernas (Kojima, 2004), eventos observados em fase posterior àquela em que os indivíduos foram coletados, o que pode ser o fator pelo qual não foram observadas modificações morfológicas visíveis e alterações no desenvolvimento de indivíduos tratados em relação aos indivíduos controle. De qualquer forma, mesmo esta pequena diminuição dos níveis de $\operatorname{crc}$ foi capaz de promover alterações na expressão de outros genes. Os genes $R f a B p$ e $E c R$-A tiveram seus níveis significativamente elevados $(\mathrm{p}<0,05)$ nas amostras silenciadas com dscrc em relação ao controle. O gene $\operatorname{crc}$ desempenha um importante papel na muda e metamorfose, principalmente através da interação com genes de resposta à ecdisona (Hewes et al., 2000). Estes autores sugerem que crc exerce um papel central na biossíntese e secreção da ecdisona ou na determinação da resposta de tecidos alvo dos ecdisteróides, podendo estar agindo desta forma na expressão dos genes por ele afetados. Como discutido anteriormente, o gene $R f a B p$ em determinadas fases dos desenvolvimento de A. mellifera, parece estar sob a influência de ecdisteróides, ora respondendo ao seus baixos níveis ora à sinergia destes com HJ. Em relação ao gene $E c R$, o perfil de expressão deste gene em A. mellifera indica uma correspondência geral com os títulos de ecdisteróides (Teles, 2007). O EcR atua como parceiro heterodimérico no receptor de ecdisona e também desempenha importante papel na muda e metamorfose mediando a ação dos ecdisteróides nestes processos (Yao et al., 1992, 1993).

\subsection{2 retinoid- and fatty acid-binding protein - RfaBp}

A diminuição de $60 \%$ nos níveis de transcritos do gene $R f a B p$ não causou alterações visíveis com relação ao timing do desenvolvimento e/ou a aspectos morfológicos. Fato que como ocorrido com o gene $c r c$, pode ser devido a fatores como tempo entre tratamento e coleta e/ou fase de desenvolvimento em que os indivíduos foram coletados. Em contrapartida, analisando os efeitos deste silenciamento na expressão de outros genes, podemos observar uma queda significativa $(p<0,05)$ nos níveis de expressão do gene codificador da esterase do hormônio juvenil (jhe). A proteína Lipoforina (Lp) ou RFABP, possui importante função no transporte de lipídios (Van Heusden \& Law, 1989) e 
outros ligantes hidrofóbicos, como por exemplo, o HJ (Trowell, 1992; Engelmann \& Mala, 2005). Podemos postular que com a diminuição dos níveis de mRNA de $R f a B p$ desencadeada pelo silenciamento também haveria uma queda na tradução da proteína, consequentemente poderia ocorrer uma deficiência no transporte de HJ entre diferentes tecidos. Deste modo, os níveis de HJ em certos órgãos e tecidos também estariam sujeitos a uma queda e, portanto a enzima que atua na regulação de seus níveis não teria seu substrato. Tal ocorrência poderia implicar na diminuição da expressão do gene codificador da esterase do hormônio juvenil (jhe). Corroborando esta hipótese, há dados de que a proteína RFABP inibe o metabolismo de HJ reduzindo a atividade de JHE (Engelmann, 1990; King \& Tobe, 1993; Gunawan \& Engelmann, 1984). Isto ocorre pela alta afinidade do HJ por RFABP, que sequestra grande parte do hormônio circulante em todos os estágios de desenvolvimento,prevenindo então, sua degradação (Tobe \& Stay, 1985). Em concordância com esta suposição temos que em baratas da espécie Leucophaea maderae a hidrólise de HJ pela JHE é parcialmente inibida pela redução de substrato disponível devido aos baixos níveis de Lp (Engelmann \& Mala, 2005). Vimos também que os maiores níveis de expressão apresentados por operárias para os dois genes encontramse na mesma fase de desenvolvimento (L5F3), o que sugere uma correlação entre eles, corroborada pelos atuais resultados e também observada em outras espécies (Engelmann \& Mala, 2005).

\subsection{3 ultraspiracle - usp}

Operárias em segundo estágio larval (L2) foram tratados com dsusp e coletadas em dois momentos diferentes do desenvolvimento, na fase pré-pupal (PP) e pupal (Pbl). Quando coletados em PP, os indivíduos não apresentavam alterações visíveis em sua morfologia e nem no timing do desenvolvimento. Mesmo assim, foi observada nas amostras obtidas com estes indivíduos uma queda significativa $(\mathrm{p}<0,05)$ nos níveis de expressão de $u s p$ de aproximadamente $50 \%$ em relação ao observado nas amostras controle. Quando as operárias tratadas com dsusp foram coletadas no final da fase pupal $(\mathrm{Pbl})$, foi observado um atraso considerável no desenvolvimento dos indivíduos em relação aos indivíduos controle, de aproximadamente 140 horas. O silenciamento de usp também foi associado a um atraso no desenvolvimento de A. mellifera por outros autores (Barchuk et al., 2008).Os níveis deste gene $u s p$ em pupas tratadas com dsusp, que estavam em $\mathrm{Pw}$, apresentaram uma queda de em 
média 30\%. Estes níveis mostraram apenas uma diferença marginal $(p=0,07)$ em relação ao controle, o que pode ser explicado pelo fato de que os dois grupos amostrais se encontravam em fases do desenvolvimento distintas ou ainda pela variação encontrada entre os indivíduos, que já foi observada em outro trabalho envolvendo silenciamento em A. mellifera (Nunes \& Simões, 2009). Os níveis de usp encontrados nas pupas $\mathrm{Pw}$ (fase em que estavam as operárias tratadas) são mais elevados que aqueles encontrados em $\mathrm{Pbl}$ (fase em que as abelhas controle estavam). Possivelmente, se comparássemos os níveis de usp encontrados nas amostras tratadas com controles ambas na fase Pw, provavelmente poderíamos observar uma queda mais acentuada na expressão deste.

Como podemos perceber, os níveis de usp foram afetados pelo tratamento com seu respectivo dsRNA o que ocasionou alterações na progressão do desenvolvimento dos indivíduos. Em acordo com a proposição de outros autores, usp atua em um mecanismo que regula a progressão do desenvolvimento pupal em A. mellifera (Barchuk et al., 2008) e também, desempenha um importante papel na metamorfose (Xu et al., 2010). Portanto, a queda em seus níveis proporcionaria a mediação inadequada dos ecdisteróides ocasionando, portanto um atraso no desenvolvimento. Além disto, usp como parceiro heterodimérico no complexo receptor de ecdisona (EcR - Oro et al., 1990; Yao et al., 1993) e possível receptor de Hormônio Juvenil (Barchuk et al., 2004; Chung et al., 1998), afetaria com seus níveis diminuídos pelo silenciamento, a expressão de toda uma cascata gênica. Inclusive aquelas estimuladas por estes hormônios (Zhang et al., 2010), o que afetaria consequentemente a progressão do desenvolvimento. Adicionalmente, foi visto que em indivíduos knockdown para o gene usp ocorre alteração nos níveis da enzima que participa da via de síntese de melanina, a Prophenoloxidase (Barchuk et al., 2008). Sabe-se que a expressão do gene codificador desta enzima está sob o controle dos ecdisteróides em A. mellifera (Zufelato et al., 2004), assim como em outros insetos (Muller et al., 1999; Ahmed et al., 1999), então o atraso no desenvolvimento das operárias silenciadas, percebido pela pigmentação da cutícula, poderia novamente ser um indício de que a ação dos ecdisteróides não está sendo mediada de forma adequada por usp. Desta forma,podemos sugerir que o fenótipo observado é uma consequência da ação conjunta de usp com outros genes regulatórios influenciados pela sua expressão. 
Resumidamente, observamos que os experimentos de knockdown de usp em A. mellifera mostraram que este gene, assim como visto em outras espécies (Oro et al., 1990; Koelle et al., 1991; Yao et al.,1992, 1993), desempenha um papel crucial no desenvolvimento pós-embrionário, especialmente durante a fase pupal (Barchuk et al., 2008). Como rainhas e operárias apresentam consideráveis diferenças em relação o timing do desenvolvimento nesta fase (Michelette \& Soares, 1994), podemos então sugerir uma atuação diferencial do gene nas vias regulatórias responsáveis pelo desenvolvimento de cada uma das castas.

\subsection{4 esterase do hormônio juvenil - jhe}

A interferência por RNA de fita dupla do gene codificador da esterase do hormônio juvenil (jhe) se mostrou bastante eficaz. Em média, houve uma queda de $60 \%$ dos níveis de expressão do gene nas amostras tratadas com dsjhe. Esta queda foi significativa $(\mathrm{p}<0,05)$ e ocasionou um ligeiro adiantamento no desenvolvimento dos indivíduos tratados em relação aos indivíduos controle, considerando-se o número de horas após a eclosão. Estes resultados sugerem que o silenciamento da jhe, mesmo que parcial, pode causar uma alteração nos níveis de HJ. Este hormônio, alvo de degradação da esterase do hormônio juvenil (JHE), desempenha um papel crucial no desenvolvimento e determinação de castas (Rachinsky et al., 1990; Hartfelder\& Engels, 1998). Rainhas de A. mellifera apresentam níveis de HJ mais elevados do que aqueles apresentados por operárias (Rembold, 1987; Rachinsky et al., 1990) e, além disto, completam seu desenvolvimento pós-embrionário mais rapidamente (ver Winston, 1987, Michelette \& Soares, 1993, Page \& Peng, 2001), indicando que o silenciamento da $j$ he, devido ao adiantamento no desenvolvimento observado, pode estar mimetizando o desenvolvimento de rainhas nestas operárias tratadas com dsjhe.

Adicionalmente a estes resultados, observamos a influência da diminuição dos níveis de $j h e$ sobre os níveis de expressão de outros genes. Notamos um aumento significativo nos níveis de expressão de $R f a B p$ e $E c R$-A, além de expressiva queda nos níveis de usp. RFABP, considerada uma das principais proteínas que se ligam ao HJ na hemolinfa, controla a taxa de metabolismo deste hormônio através desta ligação e deste modo assegura a manutenção de títulos adequados de HJ em fases determinadas do desenvolvimento (Engelmann \& Mala, 2005). Os níveis mais baixos de jhe em 
decorrência do silenciamento, possivelmente possibilitaram um aumento nos níveis de HJ, o que pode ter sido o fator responsável pela elevação dos níveis de $R f a B p$. Em relação ao que foi observado para o gene usp, é sugerido que em A. mellifera este gene participa da regulação de jhe. Esta regulação pode se dar, por exemplo, por meio da atuação de usp como receptor do HJ, agindo indiretamente nos processos do desenvolvimento dependentes deste hormônio e participando de cascatas de expressão gênica promovida por ele (Mackert et al., 2008; Barchuk et al., 2008). Desta forma, podemos sugerir um inter-relação entre os níveis de usp e jhe, em que quando os níveis de um deles cai, o mesmo ocorre com os níveis do outro. Juntamente com usp, EcR forma o complexo receptor de ecdisona (Yao et al., 1992, 1993), e desempenha importante função no desenvolvimento (Koelle et al., 1991; Talbot et al., 1993; Fujiwara et al., 1995). Encontrar níveis conflitantes para EcR e usp nas amostras tratadas com dsjhe é intrigante, mas não inesperado. Estes resultados podem ser explicados pelo fato de ter sido observada queda nos níveis de $E c R$-A, uma das isoformas do gene. A existência destas isoformas indica a razão pela qual um único hormônio (ecdisteróides) pode desencadear uma grande variedade de respostas específicas, pois, a expressão delas é diferencialmente regulada (Robinow et al., 1993; Truman et al., 1994). Portanto, jhe, por seu envolvimento na degradação do HJ, possivelmente desempenha um importante papel no desenvolvimento, assim como o $E c R$, por sua função no complexo receptor de ecdisona, o que de certa forma explica a relação entre seus níveis.

\subsubsection{PANORAMA GERAL DAS INTERAÇÕES DESENCADEADAS PELO NOCAUTE DE GENES RELEVANTES NA DETERMINAÇÃO DE CASTAS}

Em um resumo geral, os tratamentos com dsRNA produziram efeitos nos genes alvos e também nos outros genes testados. Discutimos acima as alterações que se mostraram estatisticamente significativa, mas isto não nos permite afirmar que as demais alterações encontradas não são importantes. Observamos padrões opostos nos efeitos produzido pelos tratamentos em relação aos genes testados. Como por exemplo EcR-A que teve seus níveis aumentados para todos os genes silenciados para os quais foi testado ( $c r c, R f a B p$ e $j h e)$ e jhe para o qual foi observado o contrário, níveis menores em todos os tratamentos. Os resultados encontrados pra $c r c$, queda nas amostras tratadas com seu respectivo dsRNA e aumento nas demais (dsjhe e dsRfaBp), são opostos aos 
encontrados para $E c R-\mathrm{B}$, aumento em dscrc e diminuição em dsjhe e dsRfaBp. E o terceiro par de resultados opostos foi observado para $u s p$ e $R f a B p$, com queda de usp nas amostras dsjhe e dscrc e aumento em dsRfaBp e para $R f a B p$, os resultados são antagônicos. O significado desta observação ainda é desconhecido e necessita uma análise mais detalhada. Porém, podemos novamente sugerir a existência de uma complexa rede de interação entre estes genes que atua no desenvolvimento geral e possivelmente no desenvolvimento individual das castas de A. mellifera, de acordo com o que já foi discutido anteriormente para cada um destes genes em relação aos seus perfis de expressão e efeitos do seu silenciamento.

\subsection{ATUAÇÃO DOS microRNAs NO PROCESSO DE DETERMINAÇÃO DE CASTAS}

\subsubsection{POTENCIAIS miRNAS REGULADORES DE $j h e$}

Os miRNAs evoluíram como uma classe de moléculas reguladoras de inúmeros processos biológicos em eucariotos, como proliferação celular, diferenciação, apoptose, resposta a estresse, tumorigênese, entre outros (Banerjee \& Slack, 2002; Banerjee et al., 2005; Bartel, 2004; 2009). A busca por miRNAs, potenciais reguladores de $j h e$, resultou em 22 candidatos, dos quais apenas 9 com função já descrita na literatura. Curiosamente, estes miRNAs estão envolvidos com a maioria dos processos biológicos acima citados, ou seja, em processos importantes para o desenvolvimento de insetos, especificamente, na determinação de castas em A. mellifera. Em destaque, temos os miRNAs miR-34 (Sempere et al., 2003) e let-7 (Frasch, 2008; Liu et al., 2010), envolvidos na regulação do timing de desenvolvimento em insetos, sendo ambos regulados temporalmente pelos hormônios morfogenéticos, ecdisteróides e HJ (Sempere et al., 2003). Rainhas e operárias de A. mellifera possuem timing de desenvolvimento diferentes, além da regulação diferencial do desenvolvimento pelo HJ (Rachinskyet al., 1990), portanto podemos sugerir que estes dois miRNAs, miR-34 e let-7, possam exercer um importante papel no processo de determinação de castas através da regulação de jhe. Em B. mori let-7 provavelmente está envolvido com histólise e histogênese durante a metamorfose (Liu et al., 2007). Esta morte e renovação de tecidos são disparadas por ecdisona 
(Terashima et al., 2000; Beckstead et al., 2005) e coordenada via miRNAs (Xu et al., 2002; Varghese \& Cohen, 2007). Estes processos estão intimamente ligados à diferenciação de castas assim, é possível que estes miRNAs coordenem os eventos de morte celular verificados nos ovaríolos das operárias. Além disto, miR-34 foi identificado em pulgões como forte candidato a um dos reguladores do polifenismo reprodutivo (Legeai et al., 2010) e em B. mori, foi observada expressão significativa deste miRNA, juntamente com let-7 em ovários (Liu et al., 2010), o que também foi observado para miR989 (Skalsky et al., 2010). Em C. elegans, miR-34 está envolvido no processo de morte celular. Em abelhas, miR-34 pode estar envolvido neste processo nos ovários de rainhas e operárias e de alguma forma, em sinergia com HJ seria permitida a manutenção ou a intensa morte celular programada verificada neste órgão, no processo de desenvolvimento das castas, como descrito por SchmidtCapella \& Hartfelder $(1998,2002)$. Os miRNAs miR-278 e miR-263b, sugeridos aqui como possíveis reguladores de $j h e$, também desempenham um importante papel no controle da morte celular em Drosophila (Hilgers et al., 2010). Em B. mori seus maiores níveis de expressão foram encontrados na região da cabeça (Liu et al., 2010). O desenvolvimento do cérebro, fator também muito importante no processo de determinação de castas em A. mellifera (Roat \& Cruz-Landim, 2008; Barchuk et al., 2007), pode estar sendo regulado por estes miRNAs, através de sua atuação sobre a expressão de jhe, assim como de outros genes envolvidos na formação do cérebro. Além disto, o miR-278 está envolvido no processo de crescimento em Drosophila, atuando no controle da homeostase energética (Teleman et al., 2006). O controle da divisão celular e do crescimento está ligado à via de sinalização da insulina (Teleman et al., 2006) que como já vimos, desempenha um papel crucial no processo de determinação de castas em A. mellifera, principalmente se considerarmos a nutrição e a curva de crescimento de cada uma (ver Colombani et al., 2003; Oldham \&Hafen, 2003).

Dois outros miRNAs (miR-1 e miR-8), cujas funções já são conhecidas, também são possíveis reguladores de jhe. Os miRNAs miR-1 e miR-8, em Drosophila (Nguyen \& Frasch, 2006) e B. mori (Liu et al., 2010) se encontram envolvidos com crescimento corporal. Análises de expressão gênica diferencial em A. mellifera demonstraram que em rainhas a proporção de genes fiosiometabólicos regulados positivamente é bem maior que em operárias. Dentre estes genes, estão incluídas enzimas metabólicas e genes cujos produtos são conhecidos por regularem as taxas de processo de 
transformação de massa e crescimento geral do organismo (como, por exemplo, o gene tor). Este fenômeno é uma consequência dos altos títulos de HJ em larvas de rainhas que, juntamente com a disponibilidade de nutrientes regula a expressão destes genes fisiometabólicos determinando o padrão de crescimento geral do organismo. Por outro lado, baixos níveis de HJ, combinado com quantidade limitada de nutrientes em operárias prospectivas levam ao desenvolvimento de adultos menores, neste caso sob a influência de um grupo diferente de genes, constituindo um sistema duplo de regulação do crescimento em resposta à alimentação diferencial em abelhas, tendo o HJ como um dos principais envolvidos nos processos de crescimento e desenvolvimento, e consequentemente na diferenciação de castas em A. mellifera. Deste modo, miR-1 e miR-8 seriam potenciais reguladores do processo de determinação de castas pelo seu envolvimento na regulação de $j$ he e consequentemente, dos níveis deste hormônio e secundariamente dos níveis de crescimento e atuação no estímulo cascatas de expressão gênica essenciais neste processo.

Observamos que apesar das diferentes funções desempenhadas pelos miRNAs apontados como reguladores da $j h e$, todas elas estão de alguma forma relacionadas entre si e com o processo de desenvolvimento e diferenciação. Apesar disto, para a maior parte dos miRNAs sugeridos como reguladores de $j h e$, nenhuma função foi ainda descrita, sugerindo que possivelmente são reguladores exclusivos de $A$. mellifera. Como o processo de determinação de castas nesta espécie possui peculiaridades não encontradas nem mesmo em outras espécies de abelhas, este não é um resultado surpreendente, então a análise da influência destes miRNAs sobre a expressão de $j h e$, assim como sobre outros alvos, contribuirá para uma melhor compreensão do processo de determinação de castas nesta em A. mellifera.

\subsubsection{EXPRESSÃO DE miRNAS EM RAINHAS E OPERÁRIAS}

Os microRNAs (miRNAs) são RNAs não codificadores de aproximadamente 22-nucleotídeos que desempenham importantes papéis na regulação pós-transcricional da expressão gênica, pareandose com mRNAs de genes codificadores de proteínas e interferindo na estabilidade destes, em sua tradução ou em ambos (Hendrickson et al., 2009; Guo et al., 2010). 
Os miRNAs let-7, miR-263b e miR-989, preditos como reguladores de $j h e$, apresentaram padrão de expressão antagonista em relação ao gene alvo (jhe). Tal correlação também foi observada entre jhe e o miR-2796, aqui incluído como importante na determinação de castas, visto que apresenta expressão altamente diferencial entre elas (Zayed, A., comunicação pessoal). Como discutido anteriormente, estes miRNAs estão envolvidos com importantes processos da diferenciação de castas em A. mellifera, como regulação do timing de desenvolvimento (Sempere et al., 2003), morte celular (Liu et al., 2007; Liu et al., 2010; Hilgers et al., 2010). A modulação entre os microRNAs e o gene alvo, observada em rainhas e operárias sugere que os miRNAs desempenham a mesma função em ambas, ainda que atuem em momentos diferentes do desenvolvimento.

\subsubsection{EFEITOS DO NOCAUTE DE jhe NO PADRÃO DE EXPRESSÃO DE miRNAS}

$\mathrm{Na}$ tentativa de se entender melhor o complexo mecanismo de regulação da expressão de $j h e$ especialmente no processo de determinação de castas, foram determinados em amostras silenciadas para este gene os níveis de expressão de miRNAs sugeridos por predição computacional como seus possíveis reguladores. Os miRNAs avaliados foram $m i R-1, m i R-8, m i R-12, m i R-34, m i R-263 b, m i R-$ 278, miR-989 e let-7, além do miR-2796 que foi incluído nas análises por apresentar níveis de expressão altamente diferentes entre as castas (Zayed, A., comunicação pessoal). A maioria deles apresentou um padrão de expressão que mostra um aumento dos seus níveis nas amostras tratadas com dsjhe em relação ao observado para o controle. Entre estes miRNAs estão miR-1, miR-12, miR-34, $m i R-278$ e dois daqueles discutidos acima que apresentam correlação negativa entre expressão do gene e do miRNAs. Intuitivamente espera-se que a expressão de um miRNA e a de seu alvo sigam em padrões opostos (Liang et al., 2011), isto é, quando os níveis de miRNA estão altos, espera-se que os mRNAs de seu alvo estejam baixos e vice-versa. Portanto, para os miRNAs citados acima, temos uma indicação de sua possível atuação regulando $j h e$. $\mathrm{O}$ miR-263b apresentou uma ligeira queda em seus níveis nas amostras tratadas e miR-8 e miR-2796 aparentam não ter sofrido alteração quando comparados nos dois grupos de amostras. Os níveis de expressão de jhe nas amostras tratadas com o dsRNA correspondente apresentaram um silenciamento parcial, com uma queda média de $60 \%$ nos níveis de expressão do gene, o que pode ter influenciado nestes resultados, sugerindo que esta 
alteração não foi suficiente para causar alteração nos níveis de um miRNA regulador. Além disto, é sugerido que a regulação entre miRNAs e seus genes alvos é um mecanismo complexo, que um único miRNA pode regular mais de um gene alvo e um gene pode ser regulado por vários miRNAs, por isto esta relação miRNA-alvo nem sempre segue os padrões sugeridos (Liang et al., 2011). Algumas vezes, a expressão dos miRNAs e seus alvos preditos se sobrepõem, mas em outras os alvos são expressos em níveis maiores que seus reguladores, assim como foi visto para os outros miRNAs aqui estudados, podendo-se sugerir que a repressão mediada por miRNAs pode agir contrariamente a outros processos regulatórios (Shkumatava et al., 2009).

Os miRNAs estudados, preditos como reguladores de $j$ he, estão diretamente relacionados com funções importantes no desenvolvimento e determinação de castas em A. mellifera, como por exemplo timing do desenvolvimento (Sempere et al., 2002; 2003), crescimento corporal (Nguyen \& Frasch, 2006; (Teleman et al., 2006; Liu et al., 2010), apoptose (Hilgers et al., 2010; Liu et al., 2010), reprodução (Legeai et at., 2010; Skalsky et al., 2010), entre outros, portanto analisar seu envolvimento na regulação de outro importante efetor neste processo, representou um grande avanço em relação aos fatores moleculares envolvidos em processos fundamentais que fazem parte do desenvolvimento de $A$. mellifera.

Amostras de RNA de indivíduos tratados com dsjhe e controle, foram submetidas ao sequenciamento em larga escala, para análise do perfil de miRNAs em cada grupo de amostras. Observamos clara diferença entre as bibliotecas geradas pelas amostras tratadas e controle em relação à sua composição quanto ao tamanho das reads e quanto à proporção de sequências mapeadas por entidade genética. As bibliotecas "controle" apresentam uma maior proporção de reads com tamanho entre 19 e 24 nucleotídeos (nt) enquanto que as bibliotecas "tratamento" são compostas por uma proporção maior de reads de tamanho entre 10 e $18 \mathrm{nt}$. Em relação ao mapeamento, observamos que as bibliotecas "controle" apresentam maior proporção de miRNAs e de rRNA em relação as bibliotecas "tratamento". Além disso, as bibliotecas "tratamento" apresentam aproximadamente três vezes mais reads que mapearam em genes codificadores do que as bibliotecas "controle". O significado de tais resultados é ainda desconhecido, mas podemos afirmar que interferência por RNA, causa alterações não apenas nos níveis de expressão gênica do gene alvo e de genes por ele regulados, 
mas também na composição de distribuição das moléculas reguladoras representadas pelos miRNAs. Isto pode ser corroborado pelo resultado apresentado pelas triplicatas biológicas. Vemos que a variação ocorre entre os grupos e não dentro de um mesmo grupo, o tamanho das reads e a forma como elas são mapeadas apresentam uma variação mínima dentro de um mesmo grupo, mas considerável entre eles. Divergências entre a composição de bibliotecas provenientes de diferentes grupos amostrais, já foram relatadas e sugerem uma mudança na regulação dos pequenos RNAs em diferentes condições biológicas representadas por cada grupo de amostras (Beck et al., 2011). Alterações nas porcentagens de miRNAs podem ser explicadas pelo tratamento com dsRNA, que como sabemos será clivado dentro da célula, por enzimas específicas (Keene et al., 2004; Campbell et al., 2008), de maneira a desempenhar sua função, modificando os níveis de mRNAs, assim como da tradução, o que pode explicar também as diferenças encontradas entre controle e tratamento em relação às porcentagens de sequências mapeadas contra sequências de genes codificadores de proteína.

As bibliotecas provenientes do sequenciamento em larga escala foram inicialmente caracterizadas através do mapeamento das reads nas sequências de miRNAs de $A$. mellifera, em seguida foram identificados os miRNAs diferencialmente expressos entre as bibliotecas "tratamento e controle". Selecionamos os14 miRNAs que mais se destacaram nas amostras tratadas em relação às controle. Entres estes, apenas quatro, $m i R-100, m i R-13 b, m i R-306$ e $m i R-263 b$ já foram descritos em outras espécies. Ao miR-100 foi atribuída função relativa à proliferação celular relacionada ao câncer (Henson et al., 2009). Analisando esta informação, este micro pode ter uma função relacionada também à proliferação celular em insetos, especialmente em A. mellifera, regulando os níveis de expressão de genes fisiometabólicos, importantes no desenvolvimento de rainhas (Barchuk et al., 2007; Maleszka, 2008). Se pensarmos que a queda nos níveis de jhe, causada pelo tratamento com seu respectivo dsRNA, permitiria um aumento nos títulos de $\mathrm{HJ}$ mimetizando desta forma o ambiente endógeno próprio de rainhas nas operárias tratadas com dsjhe, poderíamos explicar esta diferença nos níveis de $m i R-100$ entre as amostras tratadas e controle. $m i R-263 b$ foi um dos miRNAs preditos como possível regulador de jhe, e uma comparação de seu perfil com o perfil do gene alvo mostrou uma correlação antagônica o que reforçou a indicação de que este micro realmente age na regulação deste gene. Como foi também encontrado como diferencialmente expresso entre as amostras tratadas com 
dsjhe e controle, podemos dizer que este é um forte candidato a regulador de $j h e$, pois passou como tal em todas as abordagens utilizadas. Adicionalmente, podemos destacar sua atuação na apoptose, como sugerido por Hilgers e colaboradores (2010), processo prevenido pelos altos níveis de HJ (SchmidtCapella \& Hartfelder, 1998; 2002), e provavelmente estimulado por altos níveis de JHE, a enzima que degrada este hormônio. O terceiro miRNA diferencialmente expresso é o miR-13, que de acordo com o que já foi descrito, está também relacionado com a apoptose (Stark et a., 2003), assim como miR263b. Ambos podem estar agindo de maneira complementar, estimulados ou inibidos pelos níveis de jhe e atuando no desenvolvimento das castas em A. mellifera. O miR-306 também apresentou expressão diferencial entre os dois grupos amostrais. Em Bombyx mori ele é expresso em todos os estágios de desenvolvimento, o que indica uma possível função em processos basais ou constitutivos (Jagadeeswaran et al., 2010), que de alguma forma foram alterados pelo tratamento com longos RNAs de fita dupla. Em Drosophila este miRNA está relacionado com genes de resposta imune, ainda que seu papel não esteja totalmente elucidado (Fullaondo \& Lee, 2012). Para os demais miRNAs diferencialmente expressos, não temos informações que os caracterize, o que pode se dever ao fato de que o estudo dos miRNAs ser relativamente recente ou estes miRNAs podem constituir uma família de reguladores próprios de abelhas, por isto ainda não foram descritos, o que necessitaria de estudos mais detalhados para confirmarmos ou refutarmos estas hipóteses.

Para estes 14 miRNAs diferencialmente expressos em amostras tratadas com dsjhe e controle, foi realizada uma predição de seus potenciais genes alvos. Através desta predição, foram encontradas 1.011 interações e 562 interações quando foram utilizados somente os genes para os quais os ortólogos são conhecidos em D. melanogaster. Isto reforça a ideia de que um único miRNA possui múltiplos alvos (Lewis et al., 2005; Bushati \& Cohen, 2007). Adicionalmente, análises de GO, com os possíveis alvos dos miRNAs diferencialmente expressos mostraram a participação dos alvos, e indiretamente dos miRNAs em processos biológicos relacionados ao desenvolvimento, como por exemplo, morfogênese, desenvolvimento de apêndices, diferenciação celular, desenvolvimento de sistemas, entre outros e também com funções relacionadas a uma das castas, por exemplo a reprodução, sugerindo que o desenvolvimento de A. mellifera está sob um complexo controle, envolvendo a participação destas moléculas reguladoras. 


\subsection{PROPOSIÇÃO DE NOVAS RELAÇÕES DENTRO DO MODELO DE DETERMINAÇÃO DE CASTAS EM ABELHAS Apis mellifera}

Com os resultados aqui obtidos para os genes e moléculas reguladoras estudadas podemos sugerir um complexo modelo de regulação na diferenciação de castas envolvendo, além dos fatores propostos por outros autores, a participação destes novos reguladores. Propomos a influência destes fatores no importante processo que culmina na diferenciação de rainhas e operárias em A. mellifera, especialmente no que diz respeito às vias de sinalização que favorecem o desenvolvimento de operárias. A figura 25 representa a adição destes novos fatores de maneira a complementar ao que já se conhece sobre a regulação deste processo.

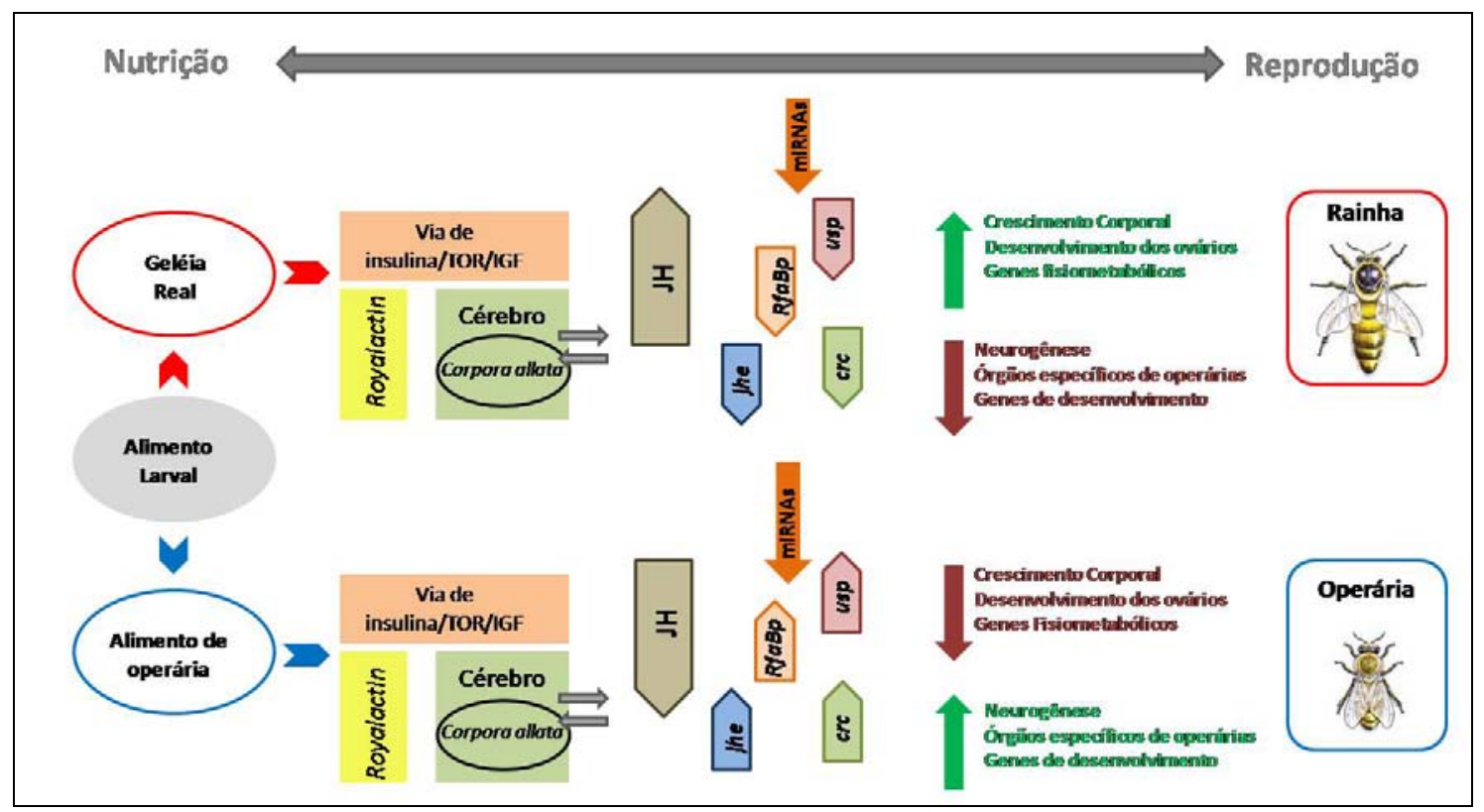

Figura 25: Modelo ilustrativo mostrando possível envolvimento dos genes (ultraspiracle - usp, cryptocephal crc, esterase do hormônio juvenil - jhe e retinoid-and fatty acid-binding protein - RfaBp) e outros fatores estudados, na determinação de castas em $A$. mellifera, juntamente com o propostos por outros autores e para este modelo. Adaptado de Malezska (2008). 


\section{CONCLUSÕES}


- Rainhas e operárias apresentam expressão gênica diferencial após o período crítico de determinação de castas, sendo que o número de genes preferencialmente expressos em operárias é maior que em rainhas, sugerindo um padrão de desenvolvimento mais complexo;

- Os genes crc, RfaBp, usp e jheestão possivelmente envolvidos no desenvolvimento de operárias dada sua expressão preferencial nesta casta;

- Este gene estudados regulam-se mutuamente, o que pode ser visto através dos resultados de silenciamento, o que contribui juntamente com outros fatores no estímulo ou inibição de vias que irão culminar no desenvolvimento de rainhas e operárias;

- As moléculas reguladoras da expressão gênica pós-transcricional, os miRNAs, são parte importante nestas vias que determinarão o futuro da uma larva de A. mellifera, agindo na regulação, em momentos específicos do desenvolvimento, especificando cada casta;

- Provavelmente não há para operárias um fator que seja o mais importante, como a royalactin em rainhas, mas sim um conjunto de fatores que age de maneira orquestrada em resposta aos estímulos nutricionais. 


\section{REFERÊNCIAS BIBLIOGRÁFICAS}


Ahmed, A.; Martín, D.; Manetti, A.G.O.; Han, S.J.; Lee, W.J.; Mathiopoulos, K.D.; Mulller, H.M.; Kafatos, F.C.; Raikhel, A.; Brey, P.T. (1999) Genomic structure and ecdysone regulation of the prophenoloxidase 1 gene in the malaria vector Anopheles gambiae. Proceedings of the National Academy of Sciences of the United States of America, 26, 1479514800.

Ayroles, J.F.; Gibson, G. (2006) Analysis of variance of microarray data. Methods Enzymol., 411:214-33.

Bai, H.; Ramaseshadri, P.; Palli, S.R. (2007) Identification and characterization of juvenile hormone esterase gene from the yellow fever mosquito, Aedes aegypti. Insect Biochem Mol Biol, 37(8):829-837.

Baker, F.C.; Tsai, L.W.; Reuter, C.C.; Schooley, D.A. (1987) In vivo fluctuations of JH, JH acid, and ecdysteroid titer, and $\mathrm{JH}$ esterase activity, during development of fifth stadium Manduca sexta. Insect Biochemistry 17: 989-996.

Banerjee, D.; Slack, F. (2002) Control of developmental timing by small temporal RNAs: A paradigm for RNA-mediated regulation of gene expression. Bioessays, 24: 119-129.

Banerjee, D.; Kwok, A.; Lin, S.Y.; Slack, F.J. (2005) Developmental timing in C. elegans is regulated by kin-20 and tim-1, homologs of core circadian clock genes. Dev Cell, 8(2):287-95.

Barchuk, A.R.; Bitondi, M.M.; Simões, Z.L.P. (2002) Effects of juvenile hormone and ecdysone on the timing of vitellogenin appearance in hemolymph of queen and worker pupae of Apis mellifera. J Insect Sci, 2:1.

Barchuk, A.R.; Maleszka, R.; Simões, Z.L.P. (2004) Apis mellifera ultraspiracle: cDNA sequence and rapid up-regulation by juvenile hormone. Insect Mol Biol, 13:459-467.

Barchuk, A.R.; Cristino, A.S.; Kucharski, R.; Costa, L.F.; Simões, Z.L.; Maleszka, R. (2007) Molecular determinants of caste differentiation in the highly eusocial honeybee Apis mellifera. BMC Dev Biol, 7:70-89.

Barchuk, A.R.; Figueiredo, V.L.C.; Simões, Z.L.P. (2008) Downregulation of ultraspiracle gene expression delays pupal development in honeybees. J Insect Physiol, 54:1035- 1040.

Bartel, D.P. (2004) MicroRNAs: Genomics, Biogenesis, Mechanism, and Function. Cell, 116:281297.

Bartel, D.P. (2009) MicroRNAs: target recognition and regulatory functions. Cell, 136(2):215-33.

Beato, M. (1989) Gene regulation by steroid hormones. Cell 56:335-344. 
Beck, D.; Ayers, S.; Wen, J.; Brandl, M.B.; Pham, T.D.; Webb, P.; Chang, C.; Zhou, X. (2011) Integrative analysis of next generation sequencing for small non-coding RNAs and transcriptional regulation in Myelodysplastic Syndromes. BMC Medical Genomics, 4:19-35.

Beckstead, R.B.; Lam, G.; Thummel, C.S. (2005) The genomic response to 20-hydroxyecdysone at the onset of Drosophila metamorphosis. Gen Biol, 6:R99.

Bellés, X.; Martín, D.; Piulachs, M.D. (2005) The mevalonate pathway and the synthesis of juvenile hormone in insects. Annu Rev Entomol, 50:181-99.

Billas, I.M.L.; Iwema, T.; Garnier, J.-M.; Mitschler, A.; Rochel, N.; Moras, D. (2003). Structural adaptability in the ligand-binding pocket of the ecdysone hormone receptor. Nature 426, 91-96.

Bloch, G.; Wheeler, D.E.; Robinson, G.E. (2002) Endocrine influences on the organization of insects societies. In: Hormones, Brain and Behavior. Eds. Donald W. Pfaff, Arthur P. Arnold, Anne M. Etgen, Susan E. Fahrbach, Robert T. Rubin. pp. 195-235. Elsevier Science, USA.

Boleli, I.C.; Simões, Z.L.P.; Hartfelder, K. (1998) The stomotogastric nervous system of the honeybee (Apis mellifera) in a critical phase of caste development. J Morphol, 236:139-149.

Burtis, K.C.; Thummel, C.S.; Jones, C.W.; Karim, F.D.; Hogness, D.S. (1990) The Drosophila 74EF early puff contains E74, a complex ecdysone- inducible gene that encodes two ets-related proteins. Cell, 61:85-99.

Bushati, N.; Cohen, S.M. (2007) microRNA functions. Annu Rev Cell Dev Biol, 23:175-205.

Campbell, C.; Keene, K.; Brackney, D.; Olson, K.; Blair, C.; Wilusz, J.; Foy, B. (2008) Aedes aegypti uses RNA interference in defense against Sindbis virus infection. BMC Microbiol, $8(1): 47$.

Caygill, E.E.; Johnston, L.A. (2008) Temporal regulation of metamorphic processes in Drosophila by the let-7 and miR-125 heterochronic microRNAs. Curr Biol, 18(13):943-50.

Chan, Q.W.T.; Melathopoulos, A.P.; Pernal, S.F.; Foster, L.J. (2009) The innate immune and systemic response in honey bees to a bacterial pathogen, Paenibacillus larva. BMC Genomics, 10:387

Chawla, A.; Repa, J.J.; Evans, R.M.; Mangelsdorf, D.J. (2001) Nuclear receptors and lipid physiology: opening the X-files. Science, 294(5548):1866-70.

Cherbas, P. (1993) The IVth Karlson Lecture: Ecdysone-responsive genes. Biochem. Mol. Biol., 23: $3-12$. 
Christianson, A.M.K.; King, D.L.; Hatzivassiliou, E.; Casas, J.E.; Hallenbeck, P.L.; Nikodem, V.M.; Mitsialis, S.A.; Kafatos, F.C. (1992) DNA binding and heteromerization of the Drosophila transcription factor chorion factor 1/ultraspiracle. Proc Natl Acad Sci USA, 89:11503-11507.

Chung, A.C.K.; Durica, D.S.; Clifton, S.W.; Roe, B.A.; Hopkins, P.M. (1998) Cloning of crustacean ecdysteoid receptor and retinoid-X receptor gene homologs and elevation of retinoiX receptor mRNA by retinoic acid. Mol Cell Endocrinol 139:209-227.

Colombani, J.; Raisin, S.; Pantalacci, S.; Radimerski, T.; Montagne, J.; Léopold, P. (2003) A nutrient sensor mechanism controls Drosophila growth.Cell., 114(6):739-49.

Colonello-Frattini, N.A.; Guidugli-Lazzarini, K.R.; Simões, Z.L.; Hartfelder, K. (2010) Mars is close to Venus - female reproductive proteins are expressed in the fat body and reproductive tract of honey bee (Apis mellifera L.) drones. J Insect Physiol 56(11):1638-1644.

Corona, M.; Estrada, E.; Zurita, M. (1999) Differential expression of mitochondrial genes between queens and workers during caste determination in the honeybee Apis mellifera. J Exp Biol, 202:929-938.

Corona, M.; Hughes, K.A.; Weaver, D.B.; Robinson, G.E. (2005) Gene expression patterns associated with queen honey bee longevity. Mech Ageing Dev, 126(11):1230-8.

Cunha, A.D.; Nascimento, A.M.; Guidugli, K.R.; Simões, Z.L.P.; Bitondi, M.M.G. (2005). Molecular cloning and expression of a hexamerin cDNA from honey bee, Apis mellifera. $J$ Insect Physiol, 51(10):1135-1147.

de Kort, C.A.D.; Granger, N.A. (1996) Regulation of JH titers: The relevance of degradative enzymes and binding proteins. Arch Insect Biochem Physiol, 33(1):1-26.

Dennis, G.; Sherman, B.T.; Hosack, D.A.; Yang, J.; Gao, W.; et al. (2003) DAVID: Database for Annotation, Visualization, and Integrated Discovery. Genome Biol 4(5): P3.

DiBello, P.R.; Withers, D.A.; Bayer, C.A.; Fristrom, J.W.; Guild, G.M. (1991). The Drosophila BroadComplex encodes a family of related proteins containing zinc fingers. Genetics, 129:385-397.

Dogra, G. S.; Ulrich, G. M.; Rembold, H. (1977) A comparative study of the endocrine system of the honeybee larvae under normal and experimental conditions. Z. Naturforsch. 32: 637-642.

Drummond-Barbosa, D.; Spradling, A.C. (2001) Stem cells and their progeny respond to nutritional changes during Drosophila oogenesis. Dev Biol; 231(1):265-78.

Elekonich, M.M.; Jez, K.; Ross, A.J.; Robinson, G.E. (2003) Larval juvenile hormone treatment affects pre-adult development, but not adult age at onset of foraging in worker honey bees (Apis mellifera). J Insect Physiol, 49:359-366. 
Engelmann, F. (1990) Hormonal control of arthropod reproduction. In: Progress in comparative endocrinology”. Eds. A. Epple, C.G. Scanes, M.H. Stetson. pp.357-364. Wiley-Liss, New York.

Engelmann, F.; Mala, J. (2005). The cockroach Leucophaea maderae needs more than juvenile hormone, vitellogenin and reserves to make a yolky egg. Journal Insect Physiology, 51: $465-$ 472 .

Evans, R.M. (1988) The steroid and thyroid hormone receptor superfamily. Science, 240(4854):88995. Evans, J.; Wheeler, D. (1999) Differential gene expression between developing queens and workers in the honey bee, Apis mellifera. Proc. Natl. Acad. Sci. USA, 96:5575-5580.

Evans, J.; Wheeler, D. (2000) Expression profiles during honeybee caste determination. Genome biology, 2(1):1-6.

Evans, J.; Wheeler, D. (2001) Gene expression and the evolution of insect polyphenisms. Bio Essays, $23: 1-7$

Ewing, B.; Green, P. (1998) Base-calling of automated sequencer traces using phred. II. Error probabilities. Genome Re,s 8:186-194.

Ewing, B.; Hillier, L.; Wendl, M.C.; Green, P. (1998) Base-calling of automated sequencer traces using phred. I. Accuracy assessment. Genome Res, 8:175-185.

Fan, Y.; Schal, C.; Vargo, E.L.; Bagnères, A.G. (2004) Characterization of termite lipophorin and its involvement in hydrocarbon transport. Journal of Insect Physiology, 50: 609-620.

Feldlaufer, M. F.; Herbert, E. W.; Svoboda, J. A.; Thompson, M. J. \& Lusby, W. R. (1985) Makisterone A. The major ecdysteroid from the pupa of the honeybee, Apis mellifera. Insect Biochem., 15(5):597-600.

Feng, Q.L.; Ladd, T.R.; Tomkins, B.L.; Sundaram, M.; Sohi, S.S.; Retnakaran, A.; Davey, K.G.; Palli, S.R. (1999) Spruce budworm (Choristoneura fumiferana) juvenile hormone esterase: hormonal regulation, developmental expression and cDNA cloning. Mol Cell Endocrinol, 148(1-2):95-108.

Frasch M. (2008) A matter of timing: microRNA-controlled temporal identities in worms and flies.Genes Dev, 22(12):1572-6.

Fristrom, J.W. (1965) Development of the morphological mutant cryptocephal of Drosophila melanogaster. Genetics, 52(2):297-318.

Fujiwara, H.; Jindra, M.; Newitt, R.; Palli, S.R.; Hiruma, K.; Riddiford, L.M. (1995). Isolation and development expression of the ecdysone receptor gene in wings of Manduca sexta. Insect Biochem. Mol. Biol. 25:845-856. 
Fullaondo, A.; Lee, S.Y. (2012) Identification of putative miRNA involved in Drosophila melanogaster immune response Devl Comp Immunol, 36:267-273.

Gauthier, A.S.; Hewes, R.S. (2006) Transcriptional regulation of neuropeptide and peptide hormone expression by the Drosophila dimmed and cryptocephal genes. J Exp Biol.; 209(10):1803-15.

Giguère, V. (1999) Orphan nuclear receptors: from gene to function. Endocr Rev, 20(5):689-725.

Gilbert, L.I.; Granger, N.A.; Roe, R.M. (2000) The juvenile hormones: historical facts and speculations on future research directions. Insect Biochem Mol Biol, 30(8-9):617-44.

Goewie, E. A. (1978) Med. Landbouwhogeschool. Wageningin, 75:1-75.

Goldstein, J.L.; Brown, M.S. (1990) Regulation of mevalonate pathway. Nature, 343:425-30.

Grad, I.; Kochman, M.; Ozyhar, A. (2002) Functionality versus strength -- has functional selection taken place in the case of the ecdysteroid receptor response element? Acta Biochim Pol., 49(3):747-56.

Green, S.; Chambon, P. (1988). Nuclear receptors enhance our understanding of transcription regulation. Trends Genet., 4: 309-314.

Guidugli, K.R.; Hepperle, C.; Hartfelder, K. (2004) A member of the short-chain dehydrogenase/reductase (SDR) superfamily is a target of the ecdysone response in honey bee (Apis mellifera) caste development Apidologie, 35:37-47.

Guidugli-Lazzarini, K.R. (2006) Expressão gênica das proteínas vitelogenina e lipoforina e seus receptores nas fases vitelogênicas e não vitelogênicas de Apis mellifera. Tese apresentada à Faculdade de Medicina de Ribeirão Preto da Universidade de São Paulo.

Gullan, P.J.; Cranston, P.S. (1994) The Insects: An Outline of Entomology. Chapman and Hall, London. $491 \mathrm{pp}$.

Gunawan, S.; Engelmann, F. (1984) Esterolytic degradation of juvenile hormone in the hemolymph of the adult female of Leucophaea maderae. Insect Biochem, 14:601-607.

Guo, H.; Ingolia, N.T.; Weissman, J.S.; Bartel, D.P. (2010) Mammalian microRNAs predominantly act to decrease target mRNA levels. Nature, 466(7308):835-840. doi:10.1038/nature09267.

Hall, B.L.; Thummel, C.S. (1998) The RXR homolog ultraspiracle is an essential component of the Drosophila ecdysone receptor. Development., 125(23):4709-17. 
Hammock, B.D. (1985) Regulation of juvenile hormone titer: Degradation. In: Kerkut GA, Gilbert LI editors. Comprehensive Insect Physiology, Biochemistry, and Pharmacology (Ed.), 7, 431-472. New York, Pergamon Press.

Hartfelder, K.; Engels, W. (1998) Social insect polymorphism: hormonal regulation of plasticity in development and reproduction in the honeybee. Curr Top Dev Biol, 40:45-77.

Hartfelder, K.; Makert, G.R.; Judice, C.C.; Pereira, G.A.G.; Santana, W.C.; Dallacqua, R.; Bitondi, M.M.G. (2006) Physiological and genetic mechanisms underlying caste development, reproduction and division of labor in stingless bees. Apidologie 37:144-163

Hendrickson, D.G.; Hogan, D.J.; McCullough, H.L.; Myers, J.W.; Herschlag, D.; Ferrell, J.E.; Brown, P.O. (2009) Concordant Regulation of Translation and mRNA Abundance for Hundreds of Targets of a Human microRNA. PLoS Biol, 7(11): e1000238. doi:10.1371/journal.pbio.1000238.

Henrich, V .C.; Brown, N. E. (1995) Insect Nuclear Receptors: A developmental and comparative perspective. Insect Biochem. Molec. Biol., 25(8): 881-897.

Henson, B.J.; Bhattacharjee, S.; O'Dee, D.M.; Feingold, E.; Gollin, S.M. (2009) Decreased Expression of $m i R-125 \mathrm{~b}$ and $m i R-100$ in Oral Cancer Cells Contributes to Malignancy. Genes Chromosomes Cancer, 48(7):569-582. doi:10.1002/gcc.20666.

Hepperle, C.; Hartfelder, K. (2000) Differential display PCR reveals ecdysteroid-responsive genes in the ovary of honeybee worker larvae. In Proceedings of the International Congress of Entomology. Edited by Gazzoni D. Londrina, Brazil: Embrapa Press, 552.

Hewes, R.S.; Schaefer, A.M.; Taghert, P.H. (2000) The cryptocephal gene (ATF4) encodes multiple basic-leucine zipper proteins controlling molting and metamorphosis in Drosophila. Genetics, .155(4):1711-23.

Hilgers, V.; Bushati, N.; Cohen, S.M. (2010) Drosophila microRNAs 263a/b confer robustness during development by protecting nascent sense organs from apoptosis. PLoS Biol, 8(6):e1000396.

Hinton, A.C.; Hammock, B.D. (2001) Purification of juvenile hormone esterase and molecular cloning of the cDNA from Manduca sexta. Insect Biochem Mol Biol, 32(1):57-66.

Hirai, M.; Kamimura, M.; Kikuchi, K.; Yasukochi, Y.; Kiuchi, M.; Shinoda, T.; Shiotsuki, T. (2002) cDNA cloning and characterization of Bombyx mori juvenile hormone esterase: an inducible gene by the imidazole insect growth regulator KK-42. Insect Biochem Mol Biol,32(6):627-35.

Honeybee Genome Sequencing Consortium (2006) Insights into social insects from the genome of the honeybee Apis mellifera. Nature, 443:931-949. 
Iwema, T.; Billas, I.M.L.; Beck, Y.; Bonneton, F.; Nierengarten, H.; Chaumot, A.; Richards, G.; Laudet, V.; Moras, D. (2007). Structural and functional characterization of a novel type of ligand-independent RXR-USP receptor. The EMBO Journal; 26: 3770-3782.

Jagadeeswaran, G.; Zheng, Y.; Sumathipala, N.; Jiang, H.; Arrese ,E.L.; Soulages; J.L.; Zhang, W.; Sunkar, R. (2010) sequencing of small RNA libraries reveals dynamic regulation of conserved and novel microRNAs and microRNA-stars during silkworm development. $B M C$ Genomics, 11:52-70.

Jindra, M.; Huang, J. Y.; Malone, F.; Asahira, M. \& Riddiford, L. M. (1997) Identification and mRNA developmental profiles of two Ultraspiracle isoforms in the epidermis and wing of the tobacco hornworm, Manduca Sexta. Insect Molec. Biol., 6:41-53.

Jousse, C.; Averous, J.; Bruhat, A.; Carraro, V.; Mordier, S.; Fafournoux, P. (2004) Amino acids as regulators of gene expression: molecular mechanisms. Biochem Biophys Res Commun.; 313:447-452.

Jung-Hoffmann, L. (1966) Die Determination von Königin und Arbeiterin der Honigbiene. $Z$ Bienenforsch, 8:296-322.

Kamakura, M.; Suenobu, N.; Fukushima, M. (2001) 57-kDaprotein in royal jelly enhances proliferation of primary cultured rat hepatocytes and increases albumin production in the absence of serum. Biochem. Biophys. Res Commun, 282, 865-874.

Kamakura, M. (2002) Signal transduction mechanism leading to enhanced proliferation of primary cultured adult rat hepatocytes treated with royal jelly 57-kDa protein. J. Biochem, 132:911-919.

Kamakura, M. (2011) Royalactin induces queen differentiation in honeybees. Nature, 473(7348):478-83.

Kapitskaya, M.; Wang, S.; Cress, D. E.; Dhadialla, T .S. \& Raikhel, A. S. (1996) The mosquito ultraspiracle homolog, a partner of ecdysteroid receptor heterodimer: cloning and characterization of isoforms expressed during vitellogenesis. Mol. Cell Endocrinol., 121:119132.

Kawooya, J.K.; Law, J.H. (1988) Role of lipophorin in lipid transport to the insect egg. The Journal of Biological Chemistry, 263(18): 8748-8753.

Keene, K.M.; Foy, B.D.; Sanchez-Vargas, I.; Beaty, B.J.; Blair, C.D.; Olson, K.E. (2004) RNA interference acts as a natural antiviral response to O'nyong-nyong virus (Alphavirus; Togaviridae) infection of Anopheles gambiae. Proc Natl Acad Sci USA, 101(49):17240-17245.

Kimura, K.; Truman, J.W. (1990) Postmetamorphic cell death in the nervous and muscular sytems of Drosophila melanogaster. J Neuroscience, 10:403-411. 
King, L.E.; Tobe, S.S. (1993) Changes in the titer of a juvenile hormone III binding lipophorin in the haemolymph of Diplopterapunctata during development and reproduction: functional significance. J Insect Physiol, 39:241-251.

Kinjoh, T.; Kaneko, Y.; Itoyama, K.; Mita, K.; Hiruma, K.; Shinoda, T. (2007) Control of juvenile hormone biosynthesis in Bombyx mori: cloning of the enzymes in the mevalonate pathway and assessment of their developmental expression in the corpora allata. Insect Biochem Mol Biol, 37(8):808-18.

Kocher, S.D.; Richard, F.J.; Tarpy, D.R.; Grozinger, C.M. (2008) Genomic analysis of postmating changes in the honey bee queen (Apis mellifera). BMC Genomics 9:232.

Koelle, M. R.; Talbot, W. S.; Segraves, W. A.; Bender, M. T.; Cherbas, P.; Hogness, D. S. (1991). The Drosophila EcR gene encodes an ecdysone receptor, a new member of the steroid receptor superfamily. Cell, 67: 59-77.

Kojima, T. (2004) The mechanism of Drosophila leg development along the proximodistal axis. Develop Growth Differ, 46:115-129.

Kutty, R.K.; Kutty, G.; Kambadur, R.; Duncan, T.; Koonin, E.V.; Rodriguez, I.R.; Odenwald, W.F.; Wiggert, B. (1996). Molecular characterization and developmental expression of a retinoid- and fatty acid-binding glycoprotein from Drosophila. A putative lipophorin. J Biol Chem, 271(34): 20641-20649.

Laidlaw, H. H. (1992) Production of queen and package bees, pp. 989-1041. In: The hive and the honey bee (Graham J., Ed.).- Dadant \& Sons, Hamilton, IL, USA.

Lan, Q.; Hiruma, K.; Hu, X.; Jindra, M. and Riddiford, L. M. (1999). Activation of a delayedearly gene encoding MHR3 by the ecdysone receptor heterodimer EcR-B1 - USP-1 but not by EcR-B1 - USP-2. Molec. Cell. Biol. 19:4897-4906.

Laudet, V. (1997) Evolution of the nuclear receptor superfamily: early diversification from an ancestral orphan receptor. J. Mol. Endocrinol. 19, 207-226.

Legeai, F.; Rizk, G.; Walsh, T.; Edwards, O.; Gordon, K.; Lavenier, D.; Leterme, N.; Méreau, A.; Nicolas, J.; Tagu, D.; Jaubert-Possamai, S. (2010) Bioinformatic prediction, deep sequencing of microRNAs and expression analysis during phenotypic plasticity in the pea aphid, Acyrthosiphon pisum. BMC Genomics, 11:281.

Levenbook, L.; Bauer, A.C. (1984) The fate of the larval storage protein calliphorin during adult development of Calliphora vicina. Insect Biochem, 14: 77-86.

Lewis, B.P.; Burge, C.B.; Bartel, D.P. (2005) Conserved seed pairing, often flanked by adenosines, indicates that thousands of human genes are microRNA targets. Cell, 120(1):15-20. 
Li, H.; Durbin, R. (2009) Fast and accurate short read alignment with Burrows-Wheeler transform. Bioinformatics, 25(14):1754-6.

Liang, Z.; Zhou, H.; Zheng, H.; Wu, J. (2011) Expression levels of microRNAs are not associated with their regulatory activities. Biol Direct, 6:43.

Liu, S.; Xia, Q.; Zhao, P.; Cheng. T.; Hong, K.; Xiang, Z. (2007) Characterization and expression patterns of let-7 microRNA in the silkworm (Bombyx mori). BMC Dev Biol, 25;7:88.

Liu, S.; Gao, S.; Zhang, D.; Yin, J.; Xiang, Z.; Xia, Q. (2010) MicroRNAs show diverse and dynamic expression patterns in multiple tissues of Bombyx mori. BMC Genomics, 2;11:85.

Livak, K.J.S.; Schmittgen, T.D. (2001). Analysis of relative gene expression data using real-time quantitative PCR and the $2^{\wedge}$ DDCt method. Methods, 25:402-408.

Lourenço, A.P.; Mackert, A.; Cristino, A.S.; Simões, Z.L.P. (2008) Validation of reference genes for gene expression studies in the honey bee, Apis mellifera, by quantitative real-time RT-PCR. Apidologie, 39:372-385.

Mackert, A.; Nascimento, A.M.; Bitondi, M.M.G.; Hartfelder, K.; Simões, Z.L.P. (2008) Identification of a juvenile hormone esterase-like gene in the honey bee, Apis mellifera L. Expression analysis and functional assays. Comp Biochem Physiol B Biochem Mol Biol 150(1): 33-44.

Maere, S.; Heymans, K.; Kuiper, M. (2005) BiNGO: a Cytoscape plugin to assess overrepresentation of gene ontology categories in biological networks. Bioinformatics, 21(16):3448-9.

Malun, D.; Giurfa, M.; Galizia, C.G.; Plath, N.; Brandt, R.; Gerber, B.; Eisermann, B. (2002) Hydroxyurea-induced partial mushroom body ablation does not effect Acquisition and Retention of olfactory differential conditioning in honeybees. J. Neurobiol., 53:343-360.

Mangelsdorf, D.J., Thummel, C., Beato, M., Herlich, P., Schutz, G., Umesono, K., Blumberg, B., Kastner, P., Mark, M., Chambon, P. and Evans, R.M. (1995) The nuclear recptor superfamily: The second decade. Cell, 83:835-839.

Maleszka, R. (2008) Epigenetic integration of environmental and genomic signals in honey bees: the critical interplay of nutritional, brain and reproductive networks. Epigenetics, 3(4):188-92.

Michelette, E.R.F.; Soares, A.E.E. (1993) Characterization of preimaginal developmental stages in Africanized honey bee workers (Apis mellifera L). Apidologie, 24:431-440.

Michener, C. D. (1974) The Social Behavior of the Bees. Harvard Univ. Press, Cambridge. 
Mortazavi, A.; Williams, B.A.; McCue, K.; Schaeffer, L.; Wold, B. (2008) Mapping and quantifying mammalian transcriptomes by RNA-Seq. Nat Methods, 5:621-628.

Muller, H.M.; Dimopoulos, G.; Blass, C.; Kafatos, F.C. (1999) A hemocyte-like cell line established from the malaria vector Anopheles gambiae expresses six prophenoloxidase genes. $\mathrm{J}$ Biol Chem, 274:11727-11735.

Nguyen, H.T.; Frasch, M. (2006) MicroRNAs in muscle differentiation: lessons from Drosophila and beyond. Curr Opin Genet Dev, 16(5):533-9.

Nijhout, H. F. (1994) Insects hormones. Princeton University Press, New Jersey.

Nunes, F.M.F.; Simões, Z.L.P. (2009) A non-invasive method for silencing gene transcription in honeybees maintained under natural conditions. Insect Biochem Mol Biol, 39(2):157-160.

Nunes-Silva, P.; Gonçalves, L.S.; Francoy, T.M.; De Jong, D. (2006) Rate of growth and development time of africanized honey bee (Apis mellifera) queens and workers during ontogenetic development. Braz. J. morphol. Sci, 23(3-4):325-332.

Oldham, S.; Hafen, E. (2003) Insulin/IGF and target of rapamycin signaling: a TOR de force in growth control. Trends Cell Biol., 13(2):79-85.

Oro, A. E.; McKeown, M. \& Evans, R. M. (1990). Relationship between the product of the Drosophila ultraspiracle locus and the vertebrate retinoid X receptor. Nature, 347: 298-301.

Page, R.E. Jr; Peng, C.Y. (2001) Aging and development in social insects with emphasis on the honey bee, Apis mellifera L. Exp Gerontol; 36(4-6):695-711.

Patel, A.; Fondrk, M.K.; Kaftanoglu, O.; Emore, C.; Hunt, G.; Frederick, K.; Amdam, G.V. (2007) The making of a queen: TOR pathway is a key player in diphenic caste development. PLOS ONE, 2(6):509.

Patrick, C.W. Jr; Zheng, B.; Wu, X.; Gurtner, G.; Barlow, M.; Koutz, C.; Chang, D.; Schmidt, M.; Evans, G.R. (2001) Muristerone a-induced nerve growth factor release from genetically engineered human dermal fibroblasts for peripheral nerve tissue engineering. Tissue Eng. 7:303311.

Perlmann, T.; Rangarajan, P. N.; Umesono, K,; Evans, R. M. (1993). Determinants for selective RAR and TR recognition of direct repeat HREs. Genes Dev. 7:1411-1422.

Perera, S.C.; Zheng, S.; Feng, Q.L.; Krell, P.J.; Retnakaran, A.; Palli, S.R. (2005) Heterodimerization of ecdysone receptor and ultraspiracle on symmetric and asymmetric response elements. Arch Insect Biochem Physiol, 60:55-70. 
Rachinsky, A.; Strambi, C.; Strambi, A.; Hartfelder, K. (1990) Caste and metamorphosis: hemolymph titers of juvenile hormone and ecdysteroids in last estágio honeybee larvae. Gen Comp Endocrinol, 79:31-38.

Rehmsmeier, M.; Steffen, P.; Hochsmann, M.; Giegerich, R. (2004) Fast and effective prediction of microRNA/target duplexes. RNA, 10:1507-1517.

Rembold H., Kremer J.-P., Ulrich G.M. (1980) Characterization of postembryonic developmental stages of the female castes of the honeybee, Apis mellifera L., Apidologie, 11:29-38.

Rembold, H. (1987). Regulation of Honeybee age polyethism by juvenile hormone. Behavioral Ecology and Sociobiology, 20:329-338.

Riddiford, L. M. (1994) Cellular and molecular actions of Juvenile Hormone I. General considerations and premetamorphic actions. Adv. Insect Physiol., 24:213-274.

Riddiford, L.M. (1996) Juvenile hormone: the status of its "status quo" action. Arch Insect Biochem Physiol, 32(3-4):271-86.

Roat, T.C.; Cruz Landim, C. (2008) Temporal and morphological differences in post-embryonic differentiation of the mushroom bodies in the brain of workers, queens, and drones of Apis mellifera (Hymenoptera, Apidae). Micron, 39(8):1171-8.

Robinow, S.; Talbot, W. S.; Hogness, D. S.; Truman, J. W. (1993). Programmed cell death in the Drosophila CNS is ecdysone-regulated and coupled with a specific ecdysone receptor isoform. Development 119:1251-1259.

Robinson, M.D.;McCarthy, D.J.; Smyth, G.K. (2010) edgeR: a Bioconductor package for differential expression analysis of digital gene expression data. Bioinformatics, 26(1):139-40.

Ryan, R.O.; Schmidt, J.O.; Law, J.H. (1984). Chemical and immunological properties of lipophorin from 7 insect orders. Arch Insect Biochem Physiol, 4: 375-383.

Sanger, F.; Nicklen, S. \& Coulson, A. R. (1977) DNA sequencing with chain-termination inhibitors. PNAS, 74:5463.

Sasorith, S.; Billas, I.M.; Iwema, T.; Moras, D.; Wurtz, J.M. (2002) Structure-based analysis of the ultraspiracle protein and docking studies of putative ligands. J Insect Sci., 2:25.

Schmidt-Capella, I.C.; Hartfelder, K. (1998) Juvenile hormone effect on DNA synthesis and apoptosis in caste-specific differentiation of the larval honey bee (Apis mellifera L.) ovary. $J$ Insect Physiol, 44(5-6):385-391. 
Schmidt-Capella, I.C.; Hartfelder, K. (2002) Juvenile-hormone-dependent interaction of actin and spectrin is crucial for polymorphic differentiation of the larval honey bee ovary. Cell Tissue Res; 307(2):265-272.

Segraves, W.A.; Hogness, D.S. (1990) The E75 ecdysone-inducible gene responsible for the 75B early puff in Drosophila encodes two new members of the steroid receptor superfamily. Genes Dev, 4:204-219.

Sempere, L.F.; Dubrovsky, E.B.; Dubrovskaya,V.A.; Berger, E.M.; Ambros, V. (2002) The Expression of the let-7 small regulatory RNA is controlled by ecdysone during metamorphosis in Drosophila melanogaster. Dev Biol, 244:170-179.

Sempere, L.F.; Sokol, N.S.; Dubrovsky, E.B.; Berger, E.M.; Ambros, V. (2003) Temporal regulation of microRNA expression in Drosophila melanogaster mediated by hormonal signals and broad-Complex gene activity. Dev Biol, 259(1):9-18.

Sevala, V; Shu, S.; Ramaswamy, S.B.; Schal, C. (1999) Lipophorin of female Blatella germanica (L.): characterization and relation to hemolymph titers of juvenile hormone and hydrocarbons. $J$ Insect Physiol, 45: 431-441.

Severson, D.; Williamson, J.; Aiken, J. (1989) Caste-specific transcription in the female honeybee. Insect Biochem, 19:215-220.

Shipman, B.A.; Ryan, R.O.; Schmidt, J.O.; Law, J.H. (1987). Purification and properties of a very high density lipoprotein from the hemolymph of the honeybee Apis mellifera. Biochesmitry, 26:1885-1889.

Shkumatava, A.; Stark, A.; Sive,H.; Bartel, D.P. (2009) Coherent but overlapping expression of microRNAs and their targets during vertebrate development. Genes Dev, 23: 466-481.

Shu, S.; Park, Y.I.; Ramaswamy, S.B.; Srinivasan, A. (1997) Hemolymph juvenile hormone titers in pupal and adult stages of southwestern Corn Borer [Diatraea grandiosella (Pyralidae)] and relationship with egg development. $J$ Insect Physiol, 43: 719-726.

Skalsky, R.L.; Vanlandingham, D.L.; Scholle, F.; Higgs, S.; Cullen, B.R. (2010) Identification of microRNAs expressed in two mosquito vectors, Aedes albopictus and Culex quinquefasciatus. BMC Genomics , 11:119.

Sparks, T.C.; Hammock, B.D.; Riddiford, L.M. (1983) The haemolymph juvenile hormone esterase of Manduca Sexta (L.) -inhibition and regulation. Insect Biochemistry 13: 529-541.

Stark, A.; Brennecke, J.; Russell, R.B.; Cohen, S.M. (2003) Identification of Drosophila MicroRNA targets. PLoS Biol, 1(3):E60. 
Sun, J.; Hiraoka, T.; Dittemer, N.T.; Cho, K.H.; Raikhel, A.S. (2000). Lipophorin as a yolk protein precursor in the mosquito, Aedes aegypti. Insect Biochemistry and Molecular Biology, 30: 11611171.

Takeuchi, H.; Fujiyuki, T.; Shirai, K.; Matsuo, Y.; Kamikouchi, A.; Fujinawa, Y.; Kato, A.; Tsujimoto, A.; Kubo, T. (2002) Identification of genes expressed preferentially in the honeybee mushroom bodies by combination of diferential display and cDNA microarray. FEBS Letters, 513: 230-234.

Talbot, W. S.; Swyryd, E. A. \& Hogness, D. S. (1993) Drosophila tissues with different metamorphic responses to ecdysone express different ecdysone receptor isoforms. Cell, 73:1323-1337.

Teleman, A.A.; Maitra, S.; Cohen, S.M. (2006) Drosophila lacking microRNA $\quad m i R-278$ are defective in energy homeostasis. Genes Dev, 20: 417-422.

Teles, A.C.A.S. (2007) Sequência DE cDNA e modulação hormonal da expressão do receptor de ecdisona $(E c R)$ em fêmeas de Apis mellifera. Dissertação apresentada à Faculdade de Filosofia, Ciências e Letras de Ribeirão Preto, Universidade de São Paulo.

Teles, A.C.A.S.; Melo, T.R.P.; Barchuk, A.R.; Simoes, Z.L.P. (2007) ultraspiracle of the stingless bees Melipona scutellaris and Scaptotrigona depilis: cDNA sequence and expression profiles during pupal development. Apidologie (Celle), 38:462-471.

Telfer, W.H.; Pan, M.L.; Law, J.H. (1991). Lipophorin in developing adults of Hyalophora cecropia: support of yolk formation and preparation for flight. Insect Biochemistry, 21(6): 653663.

Terashima, J.; Yasuhara, N.; Iwami, M.; Sakurai, S. (2000) Programmed cell death triggered by insect steroid hormone, 20-hydroxyecdysone, in the anterior silk gland of the silkworm, Bombyx mori. Dev Genes Evol, 210:545-558.

Tobe, S.S.; Stay, B. (1985) Structure and regulation of the corpusallatum. Adv Insect Physiol, 18:305-432.

Trowell, S.C. (1992). High affinity juvenile hormone carrier proteins in the hemolymph of insects. Comparative Biochemistry and Physiology Part B, 103: 795-807.

Truman, J.W.; Talbot, W.S.; Fahrbach, S.E.; Hogness, D.S. (1994). Ecdysone receptor expression in the CNS correlates with stage-specific responses to ecdysteroids during Drosophila and Manduca development. Development 120:219-234.

Truss, M.; Beato, M. (1993) Steroid hormone receptors: interaction with deoxyribonucleic acid and transcription factors. End. Rev., 14: 459-479. 
Tsai, M.J.; O'Malley, B.W. (1994) Molecular mechanisms of action of steroid/thyroid receptor superfamily members. Annu Rev Biochem., 63:451-86.

Umesono, K. and Evans, R.M. (1989) Determinants of target gene specificity for steroid/thyroid hormone receptors. Cell, 57: 1139-1146.

Van Heusden, M.C.; Law, J.H. (1989) An insect lipid transfer particle promotes lipid loading from fat body to lipoprotein. Journal of Biological Chemistry, 264: 17287-17292.

Van Heusden, M.C.; Thompson, F.; Dennis, J. (1998). Biosynthesis of Aedes aegypti lipophorin and gene expression of its apolipoproteins. Insect Biochemistry and Molecular Biology, 10: 733-738.

Varghese, J.; Cohen, S.M. (2007) microRNA $m i R$-14 acts to modulate a positive autoregulatory loop controlling steroid hormone signaling in Drosophila Genes Dev. 21(18): 2277--2282

Venkatesh, K.; Lenz, C.J.; Bergman, D.K.; Chippendale, G.M. (1987) Synthesis and release of lipophorin in larvae of the southwestern corn borer, Diatraea grandiosella: an in vitro study. Insect Biochemistry, 17(8): 1173-1180.

Vögtli, M.; Imhof, M.O.; Brown, N.E.; Rauch, P.; Spindler-Barth, M.; Lezzi, M.; Henrich, V.C. (1999) Functional characterization of two Ultraspiracle forms (CtUSP-1 and CtUSP-2) from Chironomus tentans. Insect Biochem Mol Biol., 29(10):931-42.

Ward, V.K., Bonning, B.C., Huang, T.L., Shiotsuki, T., Griffeth, V.M., Hammock, B.D. (1992) Analysis of the catalytic mechanism of juvenile hormone esterase by site-directed mutagenesis. Int J Biochem, 24:1933-1941.

Weers, P.M.; Van Marrewijk, W.J.; Beenakkers, A.M.; Van der Horst, D.J. (1993) Biosynthesis of locust lipophorin. Apolipophorins I and II originate from a common precursor. J Biol Chem, 268: 4300-4003.

Weirich, G.; Wren, J.; Siddall, J.B. (1973) Developmental changes of the juvenile hormone Esterase activity in haemolymph of the tobacco hornworm, Manduca sexta. Insect Biochem, 3:397-407.

Wheeler, D.E.; Buck, N.; Evans, J.D. (2006) Expression of insulin pathway genes during the period of caste determination in the honeybee, Apis mellifera. Insect Mol Biol, 15:597-602.

Whitfield, C.W.; Ben-Shahar, Y.; Brillet, C.; Leoncini, I.; Crauser, D.; Leconte, Y.; RodriguezZas, S,; Robinson, G.E. (2006) Genomic dissection of behavioral maturation in the honey bee. Proc Natl Acad Sci U S A, 103(44):16068-75.

Wilson, E.O. (1971). The Insect Societies. Harvard Univ. Press; Cambridge. 
Witthöft, W. (1967) Absolute Anzahl und Verteilung der Zellen im Hirn der Honigbiene. Z Morphol Tiere, 61:160-184.

Winston, M.L. (1987) The Biology of the Honey Bee. Cambridge, MA: Harvard University Press. $296 \mathrm{p}$.

Wolfinger, R.D.; Gibson, G.; Wolfinger, E.D.; Bennett, L.; Hamadeh, H.; Bushel, P.; Afshari, C.; Paules, R.S. (2001) Assessing gene significance from cDNA microarray expression data via mixed models. Journal of Computational Biology, 8: 625-637.

Xu, Y.; Fang, F.; Chu, Y.; Jones, D. and Jones, G. (2002) Activation of transcription through the ligand-binding pocket of the orphan nuclear receptor ultraspiracle. Eur J Biochem, 269(24): $6026-6036$.

Xu, J.; Tan, A.; Palli, S. R. (2010) The function of nuclear receptors in regulation of female reproduction and embryogenesis in the red flour beetle, Tribolium castaneum. J Insect Physiol, 56: $1471-1480$.

Yao, T.P.; Segraves, W.A.; Oro, A.E.; McKeown, M.; Evans, R.M. (1992). Drosophila ultraspiracle modulates ecdysone receptor function via heterodimer formation. Cell, 71:63-72.

Yao, T.P.; Forman, B.M.; Jiang, Z.; Cherbas, L.; Chen, J.D.; McKeon, M.; Cherbas, P. \& Evans, R.M. (1993) Functional ecdysone receptor is the product of EcR and Ultraspiracle genes. Nature, 366:476-479.

Yun, H.K.; Kim, W.K.; Kim, H.R. (1994). Analysis of lipophorin in the hemolymph, ovaries, and testes of the fall webworm, Hyphantria cunea (drury). Arch Insect Biochem Physiol, 27: 153-167.

Zhang, Z.; Xu, J.; Sheng, Z.; Sui, Y.; Palli, S.R. (2010) Steroid receptor co-activator is required for juvenile hormone signal transduction through a bHLH-PAS transcription factor, methoprene tolerant. J Biol Chem, http://www.jbc.org/cgi/doi/10.1074/jbc.M110.191684.

Zechel, C.; Shen, X.-Q.; Chen, J.-Y.; Chen, Z.-P.; Chambon, P.; Gronemeyer, H . (1994) The dimerization interfaces formed between the DNA binding domains of RXR, RAR and TR determine the binding specificity and polarity of the full-length receptors to direct repeats. EMBO J 13:1425-1433.

Zufelato, M.S.; Bitondi, M.M.G.; Simões, Z.L.P.; Hartfelder, K. (2000) The juvenile hormone analog pyriproxyfen affects ecdysteroid-dependent cuticle melanization and shifts the pupal ecdysteroid peak in the honey bee (Apis mellifera) Arthropod Structure \& Development, 29:111-119.

Zufelato, M.S.; Lourenço, A.P.; Simões, Z.L.P.; Jorge, J.A.; Bitondi, M.M.(2004) Phenoloxidase activity in Apis mellifera honey bee pupae, and ecdysteroid-dependent expression of the prophenoloxidase mRNA. Insect Biochem Mol Biol, 34(12):1257-1268. 
ANEXOS 
(A)

(B)

\section{(C)}

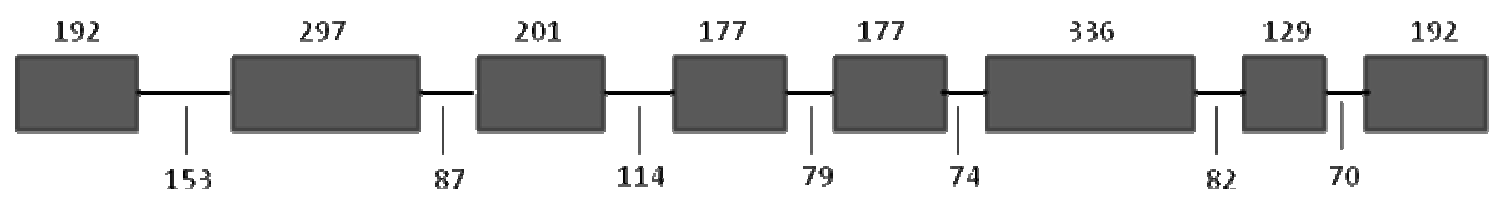

(D)

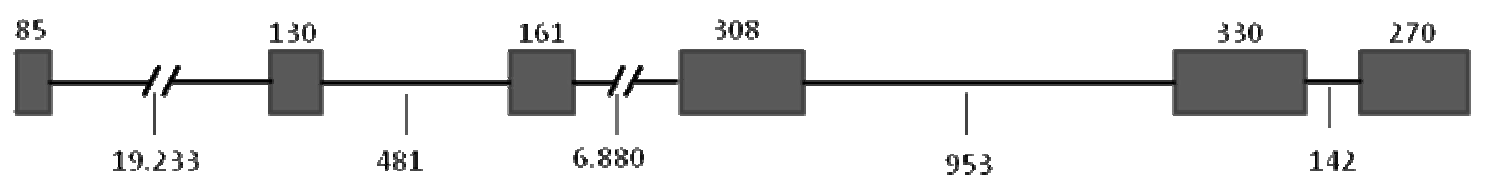

Figura 1: Organização em éxons e íntrons dos genes (A) cryptocephal (crc), (B) retinoid-and fatty acid-binding protein $(R f a B p),(C)$ ultraspiracle (usp) e (D) esterase do hormônio juvenil (jhe) determinada através de anotação gênica utilizando o pacote de programa Artemis. Os retângulos representam os éxons e as linhas entre eles representam os íntrons. Os números indicam o tamanho de cada um em pares de bases. Abaixo temos uma tabela com os tamanhos dos éxons e íntrons de $R f a B p$. 
Tabela 1: Tamanho, em pares de bases, dos éxons e íntrons que compõem o gene $R f a B p$

\begin{tabular}{|c|c|c|c|}
\hline Éxon & Tamanho & Íntron & Tamanho \\
\hline 1 & $131 \mathrm{pb}$ & 1 & $1806 \mathrm{pb}$ \\
\hline 2 & $175 \mathrm{pb}$ & 2 & $507 \mathrm{pb}$ \\
\hline 3 & $183 \mathrm{pb}$ & 3 & $266 \mathrm{pb}$ \\
\hline 4 & $4.422 \mathrm{pb}$ & 4 & $1354 \mathrm{pb}$ \\
\hline 5 & $187 \mathrm{pb}$ & 5 & $90 \mathrm{pb}$ \\
\hline 6 & $217 \mathrm{pb}$ & 6 & $172 \mathrm{pb}$ \\
\hline 7 & $293 \mathrm{pb}$ & 7 & $84 \mathrm{pb}$ \\
\hline 8 & $195 \mathrm{pb}$ & 8 & $129 \mathrm{pb}$ \\
\hline 9 & $227 \mathrm{pb}$ & 9 & $149 \mathrm{pb}$ \\
\hline 10 & $493 \mathrm{pb}$ & 10 & $112 \mathrm{pb}$ \\
\hline 11 & $185 \mathrm{pb}$ & 11 & $79 \mathrm{pb}$ \\
\hline 12 & $221 \mathrm{pb}$ & 12 & $803 \mathrm{pb}$ \\
\hline 13 & $574 \mathrm{pb}$ & 13 & $504 \mathrm{pb}$ \\
\hline 14 & $242 \mathrm{pb}$ & 14 & $477 \mathrm{pb}$ \\
\hline 15 & $223 \mathrm{pb}$ & 15 & $350 \mathrm{pb}$ \\
\hline 16 & $237 \mathrm{pb}$ & 16 & $481 \mathrm{pb}$ \\
\hline 17 & $137 \mathrm{pb}$ & 17 & $112 \mathrm{pb}$ \\
\hline 18 & $158 \mathrm{pb}$ & 18 & $680 \mathrm{pb}$ \\
\hline 19 & $184 \mathrm{pb}$ & 19 & $288 \mathrm{pb}$ \\
\hline 20 & $139 \mathrm{pb}$ & 20 & $903 \mathrm{pb}$ \\
\hline 21 & $189 \mathrm{pb}$ & 21 & $728 \mathrm{pb}$ \\
\hline 22 & $246 \mathrm{pb}$ & 22 & $126 \mathrm{pb}$ \\
\hline 23 & $225 \mathrm{pb}$ & -------------- \\
\hline & & & -------1 \\
\hline
\end{tabular}


Sequência_obtida

Sequência_predita

Sequência_obtida

Sequência_predita

Sequência_obtida Sequência_predita

Sequência obtida Sequência_predita

Sequência_obtida Sequência_predita

Sequência_obtida Sequência_predita

Sequência_obtida Sequência_predita

Sequência_obtida Sequência_predita

Sequência obtida Sequência_predita

Sequência_obtida Sequência_predita

Sequência_obtida Sequência_predita

Sequência_obtida Sequência_predita

Sequência_obtida Sequência_predita

Sequência obtida Sequência_predita

Sequência_obtida Sequência_predita

Sequência obtida Sequência_predita

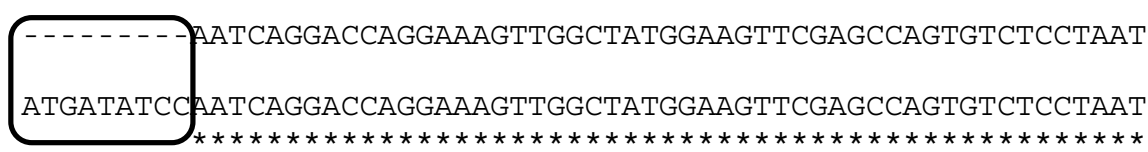

GGAACACTGTCCAATAAATTTGAAGATGATTGGTTTTTATTTGATGATAAATCTGTAGAT GGAACACTGTCCAATAAATTTGAAGATGATTGGTTTTTATTTGATGATAAATCTGTAGAT $* * * * * * * * * * * * * * * * * * * * * * * * * * * * * * * * * * * * * * * * * * * * * * * * * * * * * * * * * * * *$

CCTACTAAAAAAATTGCTGAACCTATTATGTATGAAGATCATCCTACTCGTGCACAAGTA CCTACTAAAAAAATTGCTGAACCTATTATGTATGAAGATCATCCTACTCGTGCACAAGTA

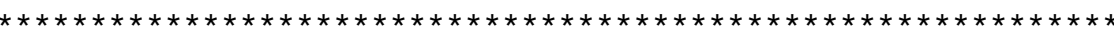

GCTACGAAACTTTTGGAAAAATTAGATGAATGGATTAAAGAAGAACCTTTTTCGGATTGG GCTACGAAACTTTTGGAAAAATTAGATGAATGGATTAAAGAAGAACCTTTTTCGGATTGG $* * * * * * * * * * * * * * * * * * * * * * * * * * * * * * * * * * * * * * * * * * * * * * * * * * * * * * * * * * * *$

TTGGAGGAGAAAATAGAATTGCCTATTTTTGAAGAACTGCCAATTACTGAAAATGGACAA TTGGAGGAGAAAATAGAATTGCCTATTTTTGAAGAACTGCCAATTACTGAAAATGGACAA

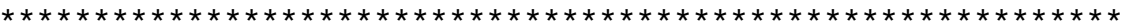

ATTAAAACAACACCATATAATGAAATTACAAAAGCTCCCCAGCAAGATGATACACAAACT ATTAAAACAACACCATATAATGAAATTACAAAAGCTCCCCAGCAAGATGATACACAAACT

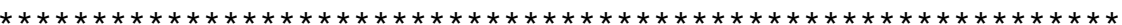

TTGCTACAAGAATTTGAAACTGTTCTGGGAGATGTGGAAGCTTGTCATCAAATAGTCCCT TTGCTACAAGAATTTGAAACTGTTCTGGGAGATGTGGAAGCTTGTCATCAAATAGTCCCT $* * * * * * * * * * * * * * * * * * * * * * * * * * * * * * * * * * * * * * * * * * * * * * * * * * * * * * * * * * * *$

TCATCAAGTTCCACTCTTACACCCCCTCAATCACCTCCATCACATAAACCATTAAATATG TCATCAAGTTCCACTCTTACACCCCCTCAATCACCTCCATCACATAAACCATTAAATATG

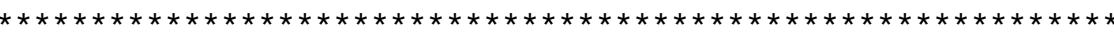

GATACTCAATTACTTGTTACTTTACAACCAGTACAACCATTATATCCTAATCATCAGTCC GATACTCAATTACTTGTTACTTTACAACCAGTACAACCATTATATCCTAATCATCAGTCC

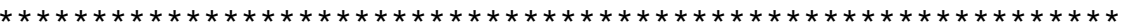

ATATATGGTATGGTAGTTCCAGAGGAAAAATCATATATAAATGAAGTACGCGTATGGCAT ATATATGGTATGGTAGTTCCAGAGGAAAAATCATATATAAATGAAGTACGCGTATGGCAT

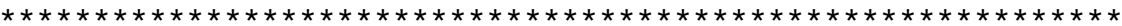

ACAAAAAATGTACCATTAGACCAGATAAACACAGATGTTGCACATGACTTAGCTGTAGTG ACAAAAAATGTACCATTAGACCAGATAAACACAGATGTTGCACATGACTTAGCTGTAGTG

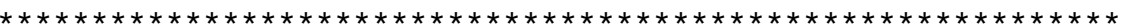

GATGAATATGTACGTTTACATACAAAAGATATTCCACCATCTAGTCCTTGTACCAGTTCT GATGAATATGTACGTTTACATACAAAAGATATTCCACCATCTAGTCCTTGTACCAGTTCT $* * * * * * * * * * * * * * * * * * * * * * * * * * * * * * * * * * * * * * * * * * * * * * * * * * * * * * * * * * * *$

GGTGGTAGCTATATTTCATCAGAAGATTCTGTGGATGATCCAGATTGGATTTTCGAATCC GGTGGTAGCTATATTTCATCAGAAGATTCTGTGGATGATCCAGATTGGATTTTCGAATCC $\star * * * * * * * * * * * * * * * * * * * * * * * * * * * * * * * * * * * * * * * * * * * * * * * * * * * * * * * * * * *$

GAAAAAAAAAATATGAAACAATCTACTTGTATTTCAACAAAAAATCGTCAAAAACCTTAT GAAAAAAAAAATATGAAACAATCTACTTGTATTTCAACAAAAAATCGTCAAAAACCTTAT

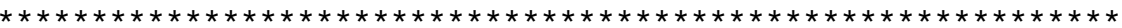

TCTCGTCCTTCAATTGAAGATAAAAAAGTTCGAAAAAAAGAACAAAATAAAAATGCAGCC TCTCGTCCTTCAATTGAAGATAAAAAAGTTCGAAAAAAAGAACAAAATAAAAATGCAGCC

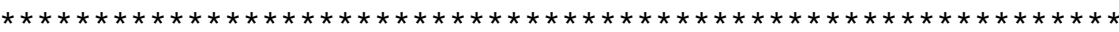

ACACGATATAGACAGAAGAAAAAACAAGAAATAAAAGAAATATTAGGTGAAGAACGTGAA ACACGATATAGACAGAAGAAAAAACAAGAAATAAAAGAAATATTAGGTGAAGAACGTGAA

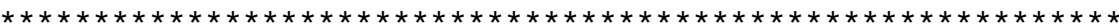


Sequência_obtida

Sequência_predita

Sequência obtida

Sequência_predita
CTTACTGAACATAATGAAAAACTAAAAAATCAAGTAACAGATTTACAACGAGAAATTGGA CTTACTGAACATAATGAAAAACTAAAAAATCAAGTAACAGATTTACAACGAGAAATTGGA

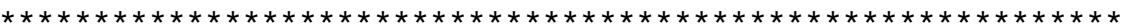

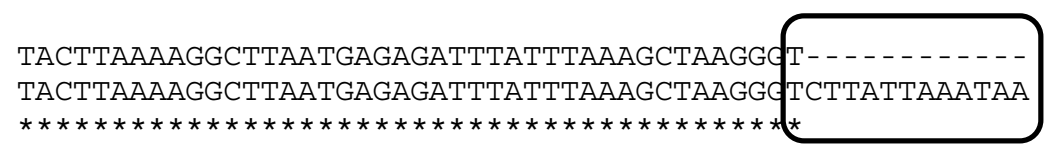

Figura 1: Alinhamento das sequências de nucleotídeos obtida através de sequenciamento (Sequência_obtida) e predita obtida pelo pacote de programas Artemis, no genoma de Apis mellifera (versão 4.0) de crc de Apis mellifera, destacando nos retângulos as regiões ausentes no fragmento sequenciado. (*) indicam posições que possuem um único resíduo completamente conservado. 
Tabela 1: Tamanho do gene e da proteína CRC e do domínio bZIP em número de aminoácidos ou nucleotídeos.

\begin{tabular}{|l|c|c|c|}
\hline \multirow{2}{*}{ ESPÉCIE } & \multicolumn{2}{|c|}{ Quantidade } \\
\cline { 2 - 4 } & $\begin{array}{c}\text { Aminoácidos em } \\
\text { CRC/ATF-4 }\end{array}$ & $\begin{array}{c}\text { Nucleotídeos } \\
\text { crc/atf-4 }\end{array}$ & $\begin{array}{c}\text { Aminoácidos no } \\
\text { domínio bZIP }\end{array}$ \\
\hline Apis mellifera & 357 & 1074 & 72 \\
\hline Nasonia vitripennis & 434 & 1302 & 72 \\
\hline Tribolium castaneum - iso1 & 318 & 954 & 72 \\
\hline Tribolium castaneum - iso2 & 248 & 744 & 71 \\
\hline Drosophila melanogaster - isoA & 381 & 1143 & 71 \\
\hline Drosophila melanogaster - isoB & 298 & 894 & 71 \\
\hline Bombyx mori & 236 & 708 & 71 \\
\hline Aedes aegypti & 405 & 1215 & 70 \\
\hline Culex quinquefasciatus & 305 & 915 & 70 \\
\hline Mus musculus & 349 & 1047 & 70 \\
\hline Bos Taurus & 348 & 1044 & 1053 \\
\hline Homo sapiens & 351 & & \\
\hline
\end{tabular}


Drosophila melanogaster - isoA Drosophila melanogaster - isoB Apis mellifera

Nasonia vitripennis

Tribolium castaneum - isol

Tribolium castaneum - iso2

Aedes aegypti

Culex quinquefasciatus

Bombyx mori

Homo sapiens

Mus musculus

Bos Taurus

Drosophila melanogaster - isoA Drosophila melanogaster - isoB Apis mellifera

Nasonia vitripennis

Tribolium castaneum - isol

Tribolium castaneum - iso2

Aedes aegypti

Culex quinquefasciatus

Bombyx mori

Homo sapiens

Mus musculus

Bos taurus

Drosophila melanogaster - isoA Drosophila melanogaster - isoB Apis mellifera

Nasonia vitripennis

Tribolium castaneum - isol

Tribolium castaneum - iso2

Aedes aegypti

Culex quinquefasciatus

Bombyx mori

Homo sapiens

Mus musculus

Bos Taurus

Drosophila melanogaster - isoA Drosophila melanogaster - isoB Apis mellifera

Nasonia vitripennis

Tribolium castaneum - isol

Tribolium castaneum - iso2

Aedes aegypti

Culex quinquefasciatus

Bombyx mori

Homo sapiens

Mus musculus

Bos Taurus

Drosophila melanogaster - isoA Drosophila melanogaster - isoB Apis mellifera

Nasonia vitripennis

Tribolium castaneum - isol

Tribolium castaneum - iso2

Aedes aegypti

Culex quinquefasciatus

Bombyx mori

Homo sapiens

Mus musculus

Bos Taurus

Drosophila melanogaster - isoA Drosophila melanogaster - isoB Apis mellifera

Nasonia vitripennis

Tribolium castaneum - isol

Tribolium castaneum - iso2

Aedes aegypti

Culex quinquefasciatus

Bombyx mori

Homo sapiens

Mus musculus
MDATFHOTMESLOLPKELYWDLKMEPOSPTSVLGSDLFPLTDSNDTEWLY MDATEHQTMESLQLPKELYWDLKMEPQSPISVLGSDLE PLTDSNDTEWLY - . - . - . - - MISNQDQESWLWKFEPVSPNGTLSNKFEDDWFLFDD - KSV - - - - - - - - MSSDQETTMLWKVEPLSPSGTPPLDIDEEWLCFDEEKPA - - - - - - - - - MSCAPFI IWKEEPLSPLSNEEVSWLSDDTFYQTSTEH - - - - - - - - - - - - - - - - - - - - - - - - - - - - - - - - - - - MESFQFLDTFDWEGKMEPSSPSSQHSSFGEELILEDYDFCND - - - - - - - - - - - - - - - - - - - - - - - - - - - - - - - - - -

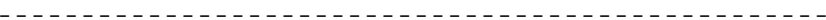
- - - - - - - -MTEMSFLSSEVLVGDLMSPFDQSGLGAEESLGLLDDYLE - - - - - - - MTEMSFLNSEVLAGDLMSPFDQSGLGAEESLGLLDDYLE - - - - - - - - -MAEMSFLSSEVLGGDFVSPFDQLGLGAEESLGLLDDNLE

DDNFANGITLIGDDEALTLEEVASLQLLSDEEMVVEIFDLKDEECLLDQK

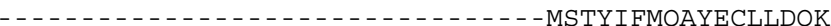
DPTKKIAEPIMYEDHPTRAQVAT- - KLLEKLD- - EWI KEEPFSDWLEEK VIESNGEESALYEEHLTRAQVAT - - KFLEELELKSWIKEESFADWLEEK EHI KFEDDLVPCESKAEVASLML - - ENLENLINLDELI KEEPSFLLDEK - - - - - - - - - - - - - - - - - - - - MAVCYEPSFLLDEK GLFNNALFDIVVETKPVIKSDLL- - - KDTTMVVALPPVEKVEKDQWLGEK - - - - - - - - - - - - - - - - - - - - - VAKHFKPHGFSSDKAKAGSSEWLAVDG - LVSPSNNSKEDAFSGTDWMLEK VAKHLKPHGFSSD - - KAGSSEWPAMDDGLASASDTGKEDAFSGTDWMLEK VAKHFKHHGFSCDKAKAGSSEWLAVDW - - - LVSDNSKEDAFSGTDWMVEK

ATLNCIDYDSNSFQPNINVITQAIVPANKVQFG- - - - - - - - - - - - - ATLNCIDYDSNSFQPNINVITQAIVPANKVQFG- - - - - - - - - - IELPIFEELPITENGQIKTTPYNEITKAPQQ - - - - - - - - - - . - . - IDLPIFEELPAPECGQNRAVVYPNIVKPPPQGQHVI IGQHQQQQQQQQHQ ILPNILDDVDQARAILPPPPTKLEYVP - - - - - - - - - - - - ILPNILDDVDQARAILPPPPTKLEYVP - - - - - - - - - - - - - - - LKI PQLSAVAGGYVSAPAAPSALVGIAPELG- - - - - - - - - - PFPN

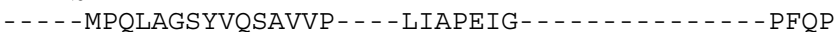
- - - - - - - - MSCRAMVSPP - - SRTARAG - - - - - - - - - AVLA MDLKEFDLDALLGIDDLETMP - - - - - - - - - - - - - - - - - - -

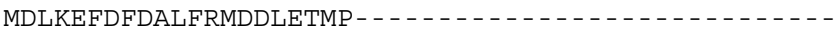
MDLKEFDFDILFSKDDLETMP - - - - - - - - - - - - - - - - - - -

- - - - ASSDAASLPSAADYQLNDGPSLILQ - - - - - QLTPPQSPPQFDA - - - - ASSDAASLPSAADYQLNDGPSLILQ - - - - - QLTPPQSPPQFDA - - - - - -DDTQTLLQEFETVLGDVEACHQIVPS-SSSTLTPPQSPPSHKP HQQLLQVDATQSLLREFETVLGDVEACHQISASGVVSTLTPPQSPPPIVK - - - - -NTDTQFLLKEFENVYDVVELTH - - - - - - ETLTPPQSPP - - - - - - - NTDTQFLLKEFENVYDVVELTH - - - - - - - ETLTPPQSPP - - - QRPPVKVQNTEELLMEFDYVYENVELTH - - - - - - - LTPPQTPPQEDQ Q - - PAKVQNTEELLMEFDCVYENVELTH - - - - - - - LTPPQTPPQEVS SSPFVTSQPTEELLREFETVYGAVELTH - - - - - - - - LTPPQSPPGP - - . - . - DDLLTTLDDTCDLFAPLVQETNKQ - . . - . . - - PPQTVNPIGH - - - - - DELLTTLDDTCDLFAPLVQETNKE- - - - - - - PPQTVNPIGH - - - - - DELLATLDDTCDLFQPLVQETNKE - - . - . - - PPQIVNPIGH

$$
\text { * : } \quad \text { *** }
$$

YKQAGDAQPKPVLVKAEQKVQCYTPDVTHAASATPFN - - - - - - - - - - - YKQAGDAQPKPVLVKAEQKVQCYTPDVTHAASATPFN - - . - . - . - . - LNMDTQLLVTLQPVQPLYPNHQS IYGMVVPEEKSYIN - - - - - - - . - . QHLVVAPQNNAHLLVALQP IHQSAFVYGQRHEESVAISPSGHVHHQQHPE - -HDYKILTTLEPLLQLPVVPEKLAYPTAMTPQ - - - - - - - - - - - - - -HDYKILTTLEPLLQLPVVPEKLAYPTAMTPQ - - - - - - - - - - - - - YHG - - - - AGEQPTYLSLPQQNPAPVGGSGEFYGYDGSLNGGIVLNQI PT FVGGQVEQQQSAPVFLAVQPEQQQVPTVIDEYYGFGAPLNGLLVN - - - - -

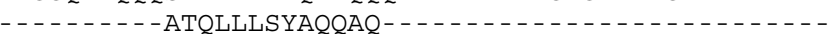
LPESLTKPDQVAPFTFLQPLPLSPGVLSSTPDHS - . - . - . - . - . LPESLIKVDQVAPFTFLQPFPCSPGVLSSTPEHS - - - - - - - - - - LPEGLPTIDQGAPFTFFQPLPPSPGTLSSTPDHS - . . . . . . . . . . _ - - - - - - - - - - - - - - - - - - - - - - - - - - - - EVRVWHTKNVPLDQIN - - TDVAHDLAVVDEYVRL SYAVSSLGLNEPIEQQIAEHWSAENLSLVPLVHGSDVAHELAKVDEYVRS - - - - - - - - - - - - PDIAHELAVVDELVRT

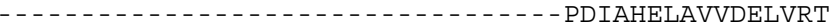
VVEQLPTAVVEPLQQVPGEYELADSFGFQPVGEEENIENNMVLVEEIIRS - - - - SIOTIVOOAOOVPGEFOLANSFGFOPVDEE-NIARNLELVEEIVRS - - - - CTALAPPAPLAPPQEAWQIVAPVPVNQLPEGYECDLDAVEELVRH - - - - - - - - - - - - - FSLELGSEVDITEGDRKPDY

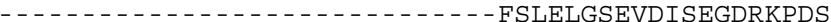


Drosophila melanogaster - isoA Drosophila melanogaster - isoB Apis mellifera

Nasonia vitripennis

Tribolium castaneum - isol

Tribolium castaneum - iso2

Aedes aegypti

Culex quinquefasciatus

Bombyx mori

Homo sapiens

Mus musculus

Bos Taurus

Drosophila melanogaster - isoA Drosophila melanogaster - isoB Apis mellifera

Nasonia vitripennis

Tribolium castaneum - isol

Tribolium castaneum - iso2

Aedes aegypti

Culex quinquefasciatus

Bombyx mori

Homo sapiens

Mus musculus

Bos Taurus

Drosophila melanogaster - isoA Drosophila melanogaster - isoB Apis mellifera

Nasonia vitripennis

Tribolium castaneum - isol

Tribolium castaneum - iso2

Aedes aegypti

Culex quinquefasciatus

Bombyx mori

Homo sapiens

Mus musculus

Bos_Taurus

Drosophila melanogaster - isoA Drosophila melanogaster - isoB Apis mellifera

Nasonia vitripennis

Tribolium castaneum - isol

Tribolium castaneum - iso2

Aedes aegypti

Culex quinquefasciatus

Bombyx mori

Homo sapiens

Mus musculus

Bos Taurus
RAKELELSTNWQQLNEDCESQASSSLDSRSTGSGVCSS - - IADADEDWVP RAKELELSTNWQQLNEDCESQASSSLDSRSTGSGVCSS - - IADADEDWVP HTKDIP - - . - . - - - - PSSPCTSSGGSYISSEDSV - - - -DDPDWIF CAEDVSYNTSSSSSASSSGPPSPCASSNASCISSEDST- - - - DDPDWAY RVEDMQWS- - - - - - - - - - - SGPSSPNSSDCSS - - - - DDPEWMP RVEDMOWS - - - - - - - - - - - SGPSSPNSSDCSS - - - DDPEWMP RSKDLPDCNDDDSCSSSEDGSVSSSCPMSDTSSSYCGSAYSRDQDDEWSP RSKDLPDCNEDDDSCSYSEADSSSPQSDSSSSSSYCGSAYSRDQDDEWSP RASQLASPQHSSSSANASPRSSPPPSPRSSS - - - - - - - - - - TDEDWS TAYVAMI PQCIKEEDTPSDNDSGICMSPESYLGSPQHSPSTR-GSPNRSL AAYITLI PPCVKEEDTPSDNDSGICMSPESYLGSPQHSPSTS - RAPPDNL -STTTGFPQCIKEEDAPSDNDSGICMSPDSSLGSPQDSPSTSRGSPNKSL

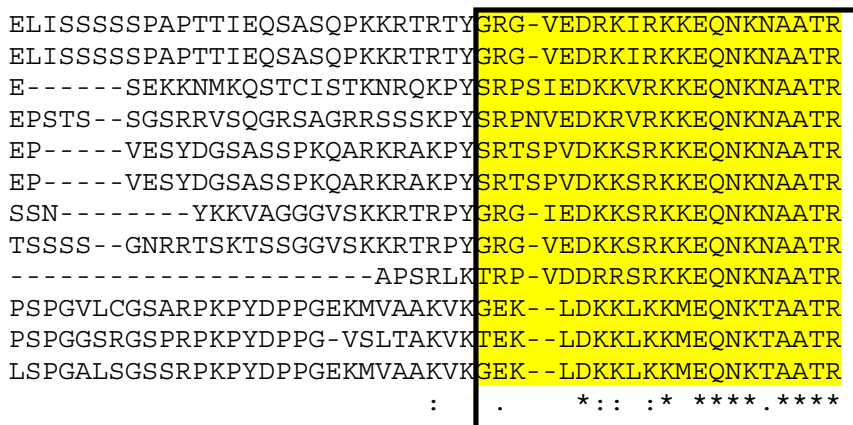

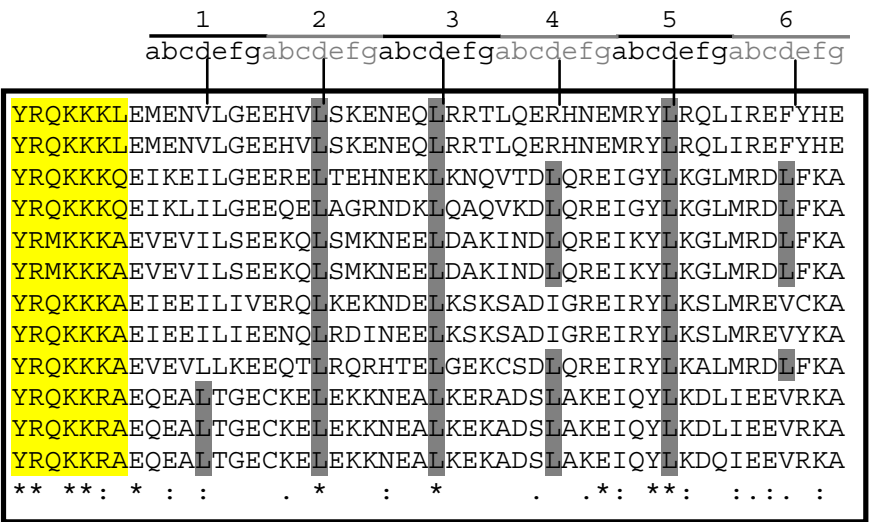

RKR - - -

RKR - - -

KGLIK- -

KGLIK- -

KGLIN- -

KGLIN - -

KGLLE - -

KGLI - - -

KGLIK- -

RGKKRVP

RGKKRVP

REKKRVL

Figura 2: Alinhamento das sequências de aminoácidos de CRC e ATF-4 de algumas espécies que mostraram similaridade com CRC de Apis mellifera. Retângulos pretos: regiões de similaridade que correspondem ao domínio conservada bZIP, grifada em amarelo: região básica do domínio bZIP, grifado em cinza: leucinas que formam os zíperes de leucina do domínio bZIP, (abdcefg) acima do segundo retângulo preto indica os grupos de sete aminoácidos que formam os zíperes de leucina nos quais a leucina está sempre na posição $d$ indicado com traços verticais ligando $d$ à primeira leucina, e acima destes grupos de sete aminoácidos está a indicação de quantos são em ordem $(1,2,3,4,5$ e 6); (*) indicam posições que possuem um único resíduo completamente conservado; (:) indicam que houve substituição de um resíduo por outro com características semelhantes, pertencentes a um mesmo grupo (ácido, básico ou neutro), o que não altera a característica geral da proteína. 


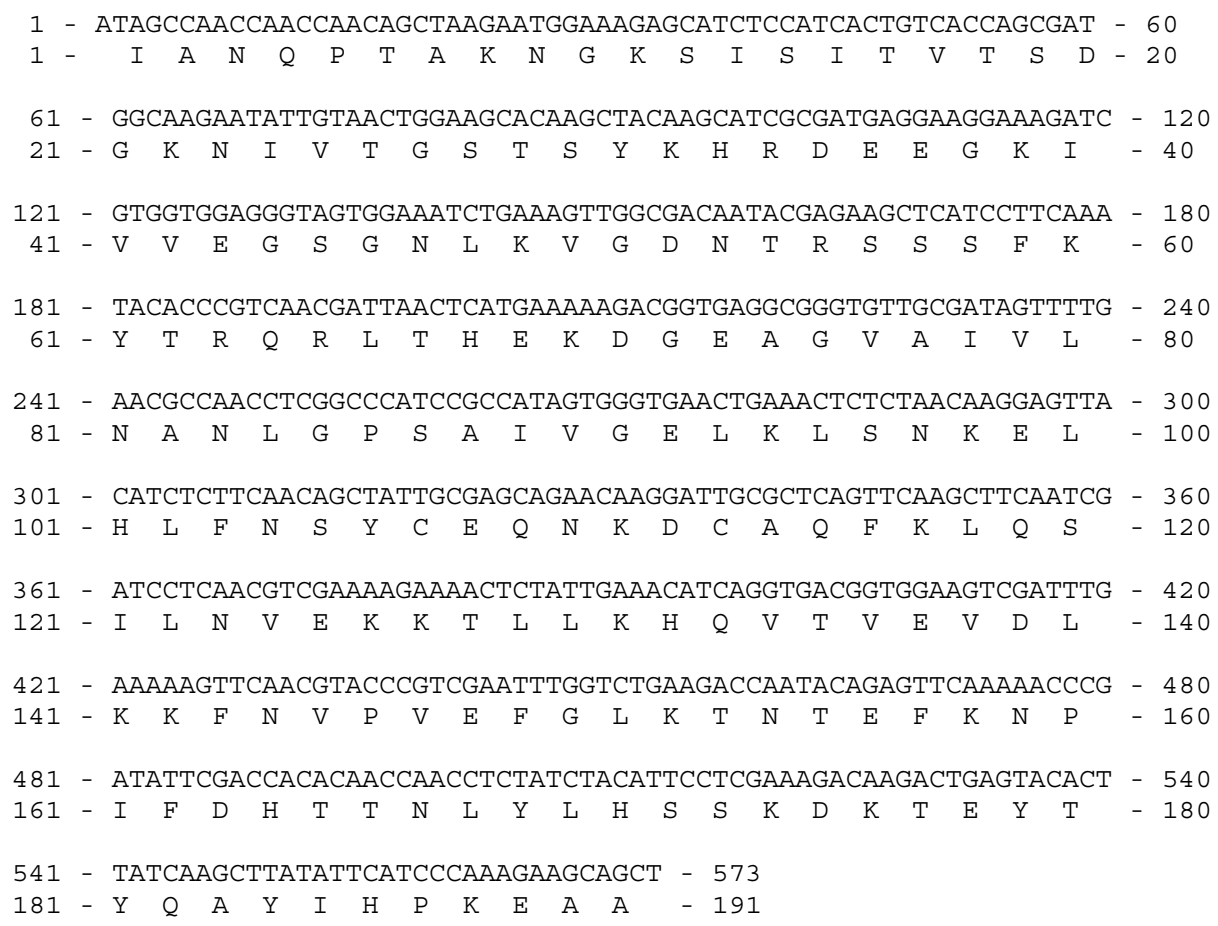

Figura 3: Sequência nucleotídica do fragmento de $R f a B p$ obtido por sequenciamento e sequência deduzida de aminoácidos. 


\section{(A)}

Sequencia_Predita Sequencia_obtida

Sequencia_Predita Sequencia_obtida

Sequencia_Predita Sequencia_obtida

Sequencia_Predita Sequencia_obtida

Sequencia_Predita Sequencia_obtida

Sequencia_Predita Sequencia_obtida

Sequencia_Predita Sequencia_obtida

Sequencia_Predita Sequencia_obtida

Sequencia_Predita Sequencia_obtida

Sequencia_Predita Sequencia_obtida

\section{(B)}

Sequência_predita sequência_obtida

Sequência_predita sequência_obtida

Sequência predita Sequência_obtida

Sequência_predita Sequência_obtida
ATCCATGCTGAAATAGCCAACCAACCAACAGCTAAGAATGGAAAGAGCATCTCCATCACT - - - - - - - ATAGCCAACCAACCAACAGCTAAGAATGGAAAGAGCATCTCCATCACT $* * * * * * * * * * * * * * * * * * * * * * * * * * * * * * * * * * * * * * * * * * * * * * * *$

GTCACCAGCGATGGCAAGAATATTGTAACTGGAAGCACAAGCTACAAGCATCGCGATGAG GTCACCAGCGATGGCAAGAATATTGTAACTGGAAGCACAAGCTACAAGCATCGCGATGAG $* * * * * * * * * * * * * * * * * * * * * * * * * * * * * * * * * * * * * * * * * * * * * * * * * * * * * * * * * * * *$

GATGGAAAGATCGTGGTGGAGGGTAGTGGAAATCTGAAAGTTGGCGACAATACGAGAAGC GAAGGAAAGATCGTGGTGGAGGGTAGTGGAAATCTGAAAGTTGGCGACAATACGAGAAGC $\star * *: * * * * * * * * * * * * * * * * * * * * * * * * * * * * * * * * * * * * * * * * * * * * * * * * * * * * * * * *$ TCATCCTTCAAATACACCCGTCAACGATTAACTCATGAAAAAGACGGTGAGGCGGGTGTT TCATCCTTCAAATACACCCGTCAACGATTAACTCATGAAAAAGACGGTGAGGCGGGTGTT $\star * * * * * * * * * * * * * * * * * * * * * * * * * * * * * * * * * * * * * * * * * * * * * * * * * * * * * * * * * * *$ GCGATAGTTTTGAACGCCAACCTCGGCCCATCCGCCATAGTGGGTGAACTGAAACTCTCT GCGATAGTTTTGAACGCCAACCTCGGCCCATCCGCCATAGTGGGTGAACTGAAACTCTCT

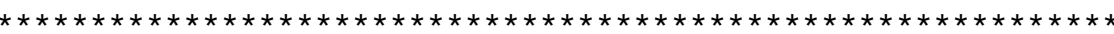

AACAAGGAGTTACATCTCTTCAACAGCTATTGCGAGCAGAACAAGGATTGCGCTCAGTTC AACAAGGAGTTACATCTCTTCAACAGCTATTGCGAGCAGAACAAGGATTGCGCTCAGTTC $\star * * * * * * * * * * * * * * * * * * * * * * * * * * * * * * * * * * * * * * * * * * * * * * * * * * * * * * * * * * *$

AAGCTTCAATCGATCCTCAACGTCGAAAAGAAAACTCTATTGAAACATCAGGTGACGGTG AAGCTTCAATCGATCCTCAACGTCGAAAAGAAAACTCTATTGAAACATCAGGTGACGGTG $* * * * * * * * * * * * * * * * * * * * * * * * * * * * * * * * * * * * * * * * * * * * * * * * * * * * * * * * * * * *$

GAAGTCGATCTGAAAAAGTTCAACGTACCCGTCGAATTTGGTCTGAAGACCAATACAGAG GAAGTCGATTTGAAAAAGTTCAACGTACCCGTCGAATTTGGTCTGAAGACCAATACAGAG $* * * * * * * * * * * * * * * * * * * * * * * * * * * * * * * * * * * * * * * * * * * * * * * * * * * * * * * * * * *$ TTCAAAAACCCGATATTCGACCACACAACCAACCTCTATCTACATTCCTCGAAAGACAAG TTCAAAAACCCGATATTCGACCACACAACCAACCTCTATCTACATTCCTCGAAAGACAAG

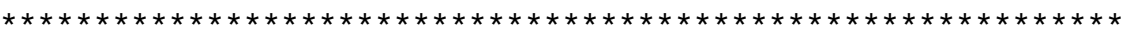

ACTGAGTACACTTATCAAGCTTATATTCATCCCAAAGAAGCAGCTACCATCCTGACTTTG ACTGAGTACACTTATCAAGCTTATATTCATCCCAAAGAAGCAGCT- - - - - - - - - - -

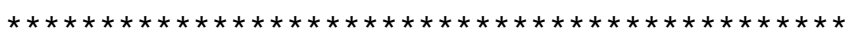

IHAEIANQPTAKNGKS ISITVTSDGKNIVTGSTSYKHRDEDGKIVVEGSGNLKVGDNTRS - - - - IANQPTAKNGKS IS ITVTSDGKNIVTGSTSYKHRDEEGKIVVEGSGNLKVGDNTRS

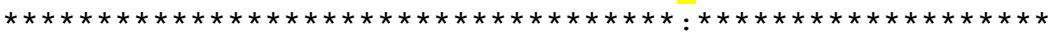

SSFKYTRQRLTHEKDGEAGVAIVLNANLGPSAIVGELKLSNKELHLFNSYCEQNKDCAQF SSFKYTRQRLTHEKDGEAGVAIVLNANLGPSAIVGELKLSNKELHLFNSYCEQNKDCAQF $\star * * * * * * * * * * * * * * * * * * * * * * * * * * * * * * * * * * * * * * * * * * * * * * * * * * * * * * * * * * *$

KLQS ILNVEKKTLLKHQVTVEVDLKKFNVPVEFGLKTNTEFKNPIFDHTTNLYLHSSKDK KLQS ILNVEKKTLLKHQVTVEVDLKKFNVPVEFGLKTNTEFKNPI FDHTTNLYLHSSKDK $\star * * * * * * * * * * * * * * * * * * * * * * * * * * * * * * * * * * * * * * * * * * * * * * * * * * * * * * * * * * *$

TEYTYQAYIHPKEAATILTLPSREVALILIYDVPKTRQTAAYKLDVSLYLDRKNKPSEKT TEYTYQAYIHPKEAA----- - - - - - - - - - - - - - - - - - - - - - - $* * * * * * * * * * * * * * *$

Figura 4: Sequências de RFABP predita e obtida mostrando o somente a região em que o fragmento obtido se alinha. A: sequência de nucleotídeos; B: sequência de aminoácidos. Grifado em amarelo: em (A) nucleotídeo diferente entre a sequência obtida e a predita, em (B) aminoácido diferente entre a sequência obtida e a predita. (*) indicam posições que possuem um único resíduo completamente conservado; (:) indicam que houve substituição de um resíduo por outro com características semelhantes, pertencentes a um mesmo grupo (ácido, básico ou neutro), o que não altera a característica geral da proteína. 
Apis_melifera Nasoñia_vitripennis Tribolium_castaneum Galeria méllonella Bombix_mori Aedes_aegypti Culex_quinquefasciatus Anopheles_gambiae Locusta migratoria Drosophila_melanogaster

Apis_melifera Nasonia_vitripennis Tribolium castaneum Galeria mēllonella Bombix_mori

Aedes_aegypti

Culex quinquefasciatus Anopheles_gambiae Locusta migratoria Drosophila_melanogaster

Apis_melifera Nasonia_vitripennis Tribolium castaneum Galeria méllonella Bombix mori

Aedes_àegypti

Culex_quinquefasciatus Anophēles gambiae

Locusta_migratoria

Drosophìla_melanogaster

Apis melifera

Nasonia_vitripennis Tribolium castaneum Galeria mēllonella Bombix mori

Aedes_àegypti

Culex_quinquefasciatus

Anopheles_gambiae

Locusta_migratoria

Drosophìla_melanogaster

Apis melifera

Nasoñia_vitripennis

Tribolium_castaneum

Galeria mellonella

Bombix_mori

Aedes_aegypti

Culex_quinquefasciatus

Anophêles_gambiae

Locusta migratoria

Drosophìla_melanogaster
- - - - - - - - - - IANQPTAKNGKS ISITVTSDGKNIVTGSTSYKHRDEE DSDKLKYRKIHAEIANKPSTPDGRAIFITVTSDGKNLVTGSTNYKRHEED NAPTLKIDKYVIEAQNKP-AKTGRRIQVTAKSGNKNILAGSTSYTAREEH NSEKLGLKNYKVDVATKDANNNGKRLEFQATNDNKNVLSGSTTFISKQEN NAKELGWKNYGIDISSKDSGS-GKRLEFHATNDNKNVLSGSTSFISKQEG DAPKLDAKKITVEINSKP - GNSGKGVEFKASSDGKNVLSGFADYSVKEQG DAPKLNANKVSVELHSKP-GNSGKGVEFKASSDGKNILSGYADYSVKEQG DAPMLNTNKFSVEVNAKP-GSNGKGVNFRASEGGKDILSGFADYSVKEQG DSPKFNFNKWHLEAGQRA-AKGSKRIVFTAKSAEKVLFSGSTNFHSKAEN SSKKLKLDGYELEARAQS - - - - KNIKIQLKNENGI IFSGTATYALKKEL : $\quad: \quad: \quad . \quad \ldots \quad::^{*}: \quad: \quad:$ : GKIVVEGSGNLKVGDNTRSSSFKYTRQRLTHEKDGEAGVAIVLNA-NLGP KKITLEGNGSLKIGENTKSSSFKYVRKQLTRENDKEVGVAIMLNA-SFGP GKVIIEGSGSFKLHDETKSANFKYIRQNLVQAKNGETGIEISFDA-SLGN KKTI IEGSGTLKVKEEQKSANFKYIRTILTEGN- -EQGVETFLNL-AVGE QKTI IEGSGSVKVKEEQKSANFKYIRTVFTDSN--EKGVETFFNV-ALGE KSTVIEGQGNVKLYDKQQTASFKLVREKLQEAG-- - - YAFTLSG-SVGK KTTI IEGQGNVKLYDKQQTASFKLVREKLSESG-- - - - YALNLAG-SVGK KAMVIEGQGNVKLYDKQQTATFKLIREKLSESG- - - - MSATLTA-SVGK NKISYSGNGQVRIGDKAHAFNFRSSRQNLIQDANKEIGVEYNLDFXIAGH NKTI IDGQGKVQYQGKALSGNFKLTRQHFDFGTDREVGFSYTFMG-NLGS

$$
\text { .*. * : : : }{ }^{*}: \quad \text { * : }
$$

SAIVGELKLSNKELHLFNSYCEQNK-DCAQFKLQS ILNVE--KKTLLKHQ SGIVGELKLSDKEVLVFNSYCEQSK-DCAQFKLQSTLDTD--HLTHLNHN KAIDAELKITDKQFRILNSYCEEKK-QCAHVEVDVKTTVD- -DVKAFNQE SSYVAESRITNLEYKNSYVYCEEKK-QCAHVELNSKVNIQ- -KPGVVQHT RSYVAESRVTNYEYKNSYVYCEEKK-QCAHAEIQSKIDMS - -TPGMIVNV NSVSTEVRVKPNDFKLKHTVCDEKK-KCTNVEVQSKLER-- - VGEKFNHE NSITTEVRVKPNDFLLKHTVCDEKK-QCTNVAVQSKLER---AGDKFNHE FTVLHESRVQPNDFRVKTSVCDEKK-KCTKLELLSKLER---AAGAFKHE GSLHNILKVTNKELHALGKQCSEGKPNCAVVEIKSKVSAA--DAKETTHD KNGLGTLKITNKEFNTKFSVCEEKR-QCTNLIVQS IVS IDEQKLDAVEHT

$$
:: \quad: \quad * .: \quad \text { : * : : }
$$

VTVEVDLKKFNVPVEFGLKTNTEFKNPI FDHTTNLYLHSSKDKTEYTYOA LQVEVNLKKFNVPVEFGLMSSTKYADYSLDHQANLYLHSSKDRTQYTYHV IEIAIDLRKLGLSHEFGLKAVTTRKEYVLDHTVDMHFQS - QENSKYQYSL VNVNFDLVKLGISPEFGLQITNEISEKKLPQYT-LDLHAI KNDKKYHLNI INAGLDLRKLGVAPELGLQMRDEVSDRRPPRFT - LDLHINKEDRKYHLHA ALISVDLQQLGYVYEFGLNSKTSGNGFTLDHTTDVELKE - KQQPKYQYHL AQISVDLQQLGYDHEFGLSAKTQGNGFTLDHTTDVKLSE - KKQPKYQYQL ALVSVEVQQMGYEHEFGLSAKTSANGLKFDHTTDVQLKE - KNQPKYQYLF LVFLVDLKSVGVDTGVAFTAETVRRGFWLIDEQASLTLSHNGETTYKYKG TLIIVDLRDFGYPYEFELKSQNTRQGLKYQYHLDSFIIT-GNNFKYQFTA .$:$ : . . : YIHPK- - -EAAX - YSNKR - - -ESAAVLSLPSRELAIVAFHDVPTV- - KHSGAYKIDISLYLD YVHPN - - - QAGVSLTTPKRI IALESKINVPSK- - FLQDGGSVSGEVFFY YSHPELGKFPAGITVTLPHRVLALETRVEYPTN - KGLPFPIKGEITIHP YNTPENGHYASGVTVRLPSRVMALEYTLTHPTS - - QDLPFPIKGEACLDL YLHPH - - - SAGASLVLPTRSLVVEGVFNYPKD- - KFGQYDSTVSFYLDK FIHPN - - - EAGARLILPSRS IALEGNFHYPKE- - KFGKYDSTVSFYLDK YVHPT - - - SAGASLILPTRTVAVEGVLNLPKD- - KFGPFDGSVSFYLDK YLKES - - - GSGFTLTLPSRVIAAEVKLSSDVK - - PNHSKQQISASVWLD NVQPT - - - SSTIKLALPKRQILFETTQKI PADGSLFGRYEQTASFFIDK :

Figura 5: Alinhamento das sequências de aminoácidos de RFABP, apolipoforinas de algumas espécies que mostraram similaridade com RFABP de Apis mellifera. Nesta figura está representada somente a região onde houve alinhamento das sequências. (*) indicam posições que possuem um único resíduo completamente conservado; (:) e (.) indicam que houve substituição de um resíduo por outro com características semelhantes, pertencentes a um mesmo grupo (ácido, básico ou neutro), o que não altera a característica geral da proteína. 
ANEXO 3 


\title{
ANEXO 3A - LISTA DO EXCEL DEGs
}

\author{
(vide CD)
}




\section{ANEXO 3B}

Tabela 1: Análises de GO mostrando os processos biológicos nos quais estão envolvidos a maior parte dos genes diferencialmente expressos entre as amostras controle e tratadas com dsGFP. Estes processos provavelmente são afetados pelo tratamento dom dsGFP e portanto, poderão resultar em um falso positivo nas análises, dependendo do gene alvo estudado. Células em cinza escuro: categorias representadas por genes com níveis de expressão aumentados pelo tratamento com dsGFP, células em cinza claro: categorias representadas por genes com níveis de expressão diminuídos pelo tratamento com dsGFP.

\begin{tabular}{|c|}
\hline $\begin{array}{c}\text { Processo Biológico } \\
\text { Processo metabólico }\end{array}$ \\
\hline Regulação da expressão gênica \\
Transporte \\
\hline Localização celular \\
\hline $\begin{array}{c}\text { Desenvolvimento da musculatura } \\
\text { esquelética }\end{array}$ \\
\hline Organização da sinapse \\
\hline Sinalização celular \\
\hline Desenvolvimento \\
\hline Morte celular \\
\hline Morfogênese \\
\hline Resposta imune \\
\hline Reprodução \\
\hline Organização da cromatina \\
\hline Neurogênese \\
\hline
\end{tabular}


Tabela 1: "top list" dos genes diferencialmente expressos entre amostras controle e tratadas com dsGFP, para os quais se deve ter atenção quando experimentos de tratamento com RNA de fita dupla forem analisados. Células destacadas em cinza escuro : indicam genes que tiveram seus níveis de expressão aumentados nas amostras dsGFP; células destacadas em cinza claro: indicam genes que tiveram seus níveis de expressão diminuídos nas amostras dsGFP. *Optamos por manter a descrição das funções biológicas dos genes em inglês devido à falta de termos, em alguns casos, que traduzisse seu real significado.

\begin{tabular}{|c|c|}
\hline $\begin{array}{l}\text { GB/nome do } \\
\text { gene }\end{array}$ & Processo Biológico \\
\hline GB15413 - HNK-1 & Processo biossintético de carboidratos \\
\hline GB17328 - Mblk-1 & $\begin{array}{c}\text { Ativação da atividade de caspases, indução de } \\
\text { apoptose por hormônios, morte celular } \\
\text { autofágica. }\end{array}$ \\
\hline GB10201 bHLH-PAS & Regulação da transcrição \\
\hline GB12218 His1 & Compactação e descompactação da cromatina \\
\hline GB18593 & Transporte transmembrana \\
\hline GB20148 pyd3 & Processo biossintético de pirimidinas \\
\hline GB17541 & Regulação positive da apoptose \\
\hline $\begin{array}{l}\text { GB10133 - superóxido } \\
\text { dismutase (Sod1) }\end{array}$ & $\begin{array}{l}\text { Determinação do tempo de vida do adulto, } \\
\text { resposta a stress oxidativo }\end{array}$ \\
\hline GB13038 & $\begin{array}{l}\text { Citocinese na meiose masculina, } \\
\text { desenvolvimento da espermátide, crescimento do } \\
\text { espermatócito primário, divisão do } \\
\text { espermatócito. }\end{array}$ \\
\hline GB13879 & desconhecida \\
\hline GB13812 - spatzle & $\begin{array}{c}\text { Estabelecimento do eixo dorsal-ventral, resposta } \\
\text { imune inata }\end{array}$ \\
\hline GB17681 - Actina & $\begin{array}{l}\text { Individualização espermática, comportamento } \\
\text { agressivo entre machos; citocinese, } \\
\text { desenvolvimento dos corpos cogumelares } \\
\text { (mushroom body), manutenção da localização de } \\
\text { proteínas na célula, fagocitose. }\end{array}$ \\
\hline GB12312 & Desconhecida \\
\hline GB13094 & Desconhecida \\
\hline GB14564 - viking (vkg) & $\begin{array}{l}\text { Morfogênese dos túbulos de Malpighi, } \\
\text { desenvolvimento do músculo esquelético. }\end{array}$ \\
\hline $\begin{array}{l}\text { GB12586 - Protein } \\
\text { disulfide-isomerase } \\
\text { precursor (PDI) }\end{array}$ & Dobramento de proteínas \\
\hline GB10459 - clumsy & Transporte de íons. \\
\hline GB14742 & Desconhecida \\
\hline GB14309 & Proteólise \\
\hline GB12378 & Morte celular autofágica, \\
\hline
\end{tabular}


ANEXO 4 


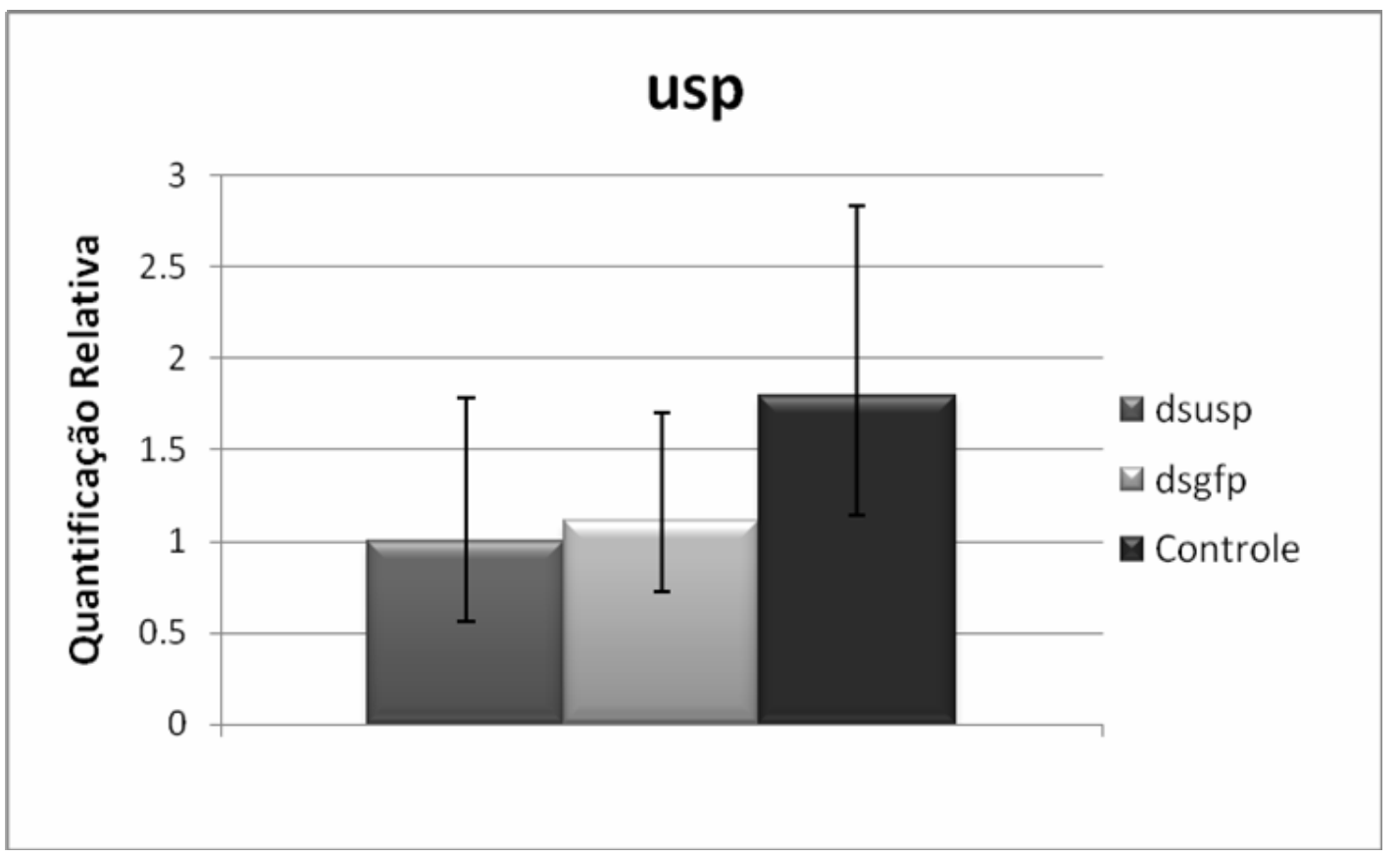

\section{RfaBp}

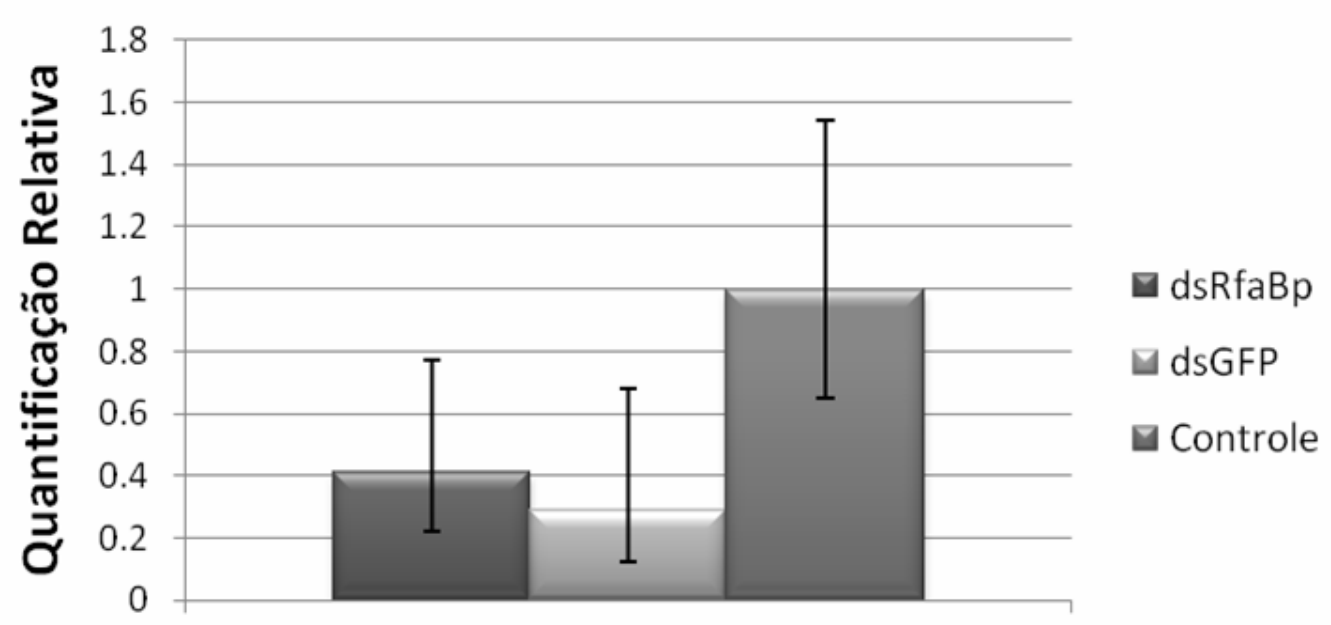




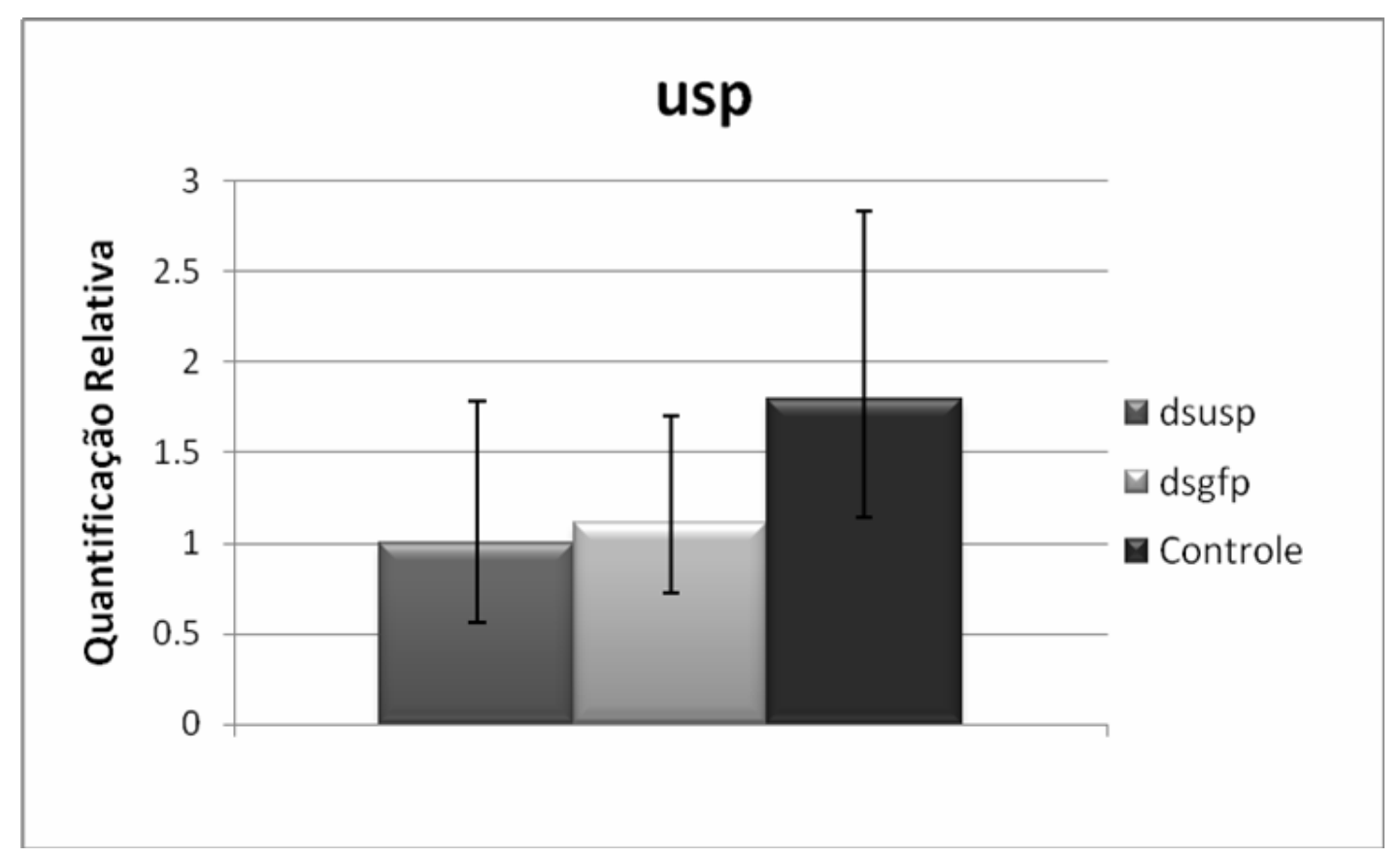

Figura 1: Quantificação relativa de mRNAs em operárias de Apis mellifera para os genes cryptocephal (crc), retinoid- and fatty acid-binding protein $(R f a B p)$ e ultraspiracle (usp) tratadas no segundo estágio larval, L2 com 1,0 $\mu \mathrm{g}$ de dscrc $(\mathrm{n}=8)$ ou 1,0 $\mu \mathrm{g}$ de dsRfaBp $(\mathrm{n}=10)$ ou 5,0ug de dsusp $(\mathrm{n}=4) ;$ tratadas com 1,0 $\mu \mathrm{g}$ ou 5,0 $\mu \mathrm{g}$ de dsGFP e asmotras controle, para as quais nenhum tipo de tratamento foi administrado. Este resultados mostram o efeito do dsRNA utilizado como controle, dsGFP, na expressão dos genes alvo. Os indivíduos tratados foram coletados em L5S1 ( $c r c$ e $R f a B p)$ e PP e Pbl (usp). Os valores de expressão obtidos para o gene codificador de RP-49 foram utilizados para normalização da expressão de dos genes alvo. Os dados de cada grupo correspondem à expressão da média de amostras contendo 1 indivíduo cada, e as linhas representam o desvio padrão das amostras, obtido de acordo com o que foi proposto por Livak \& Schmittgen (2001). 


\title{
ANEXO 5A - Tabela Excel DEGs RxOP
}

\author{
(vide CD)
}


ANEXO 5B -Tabela de GO

(vide CD) 

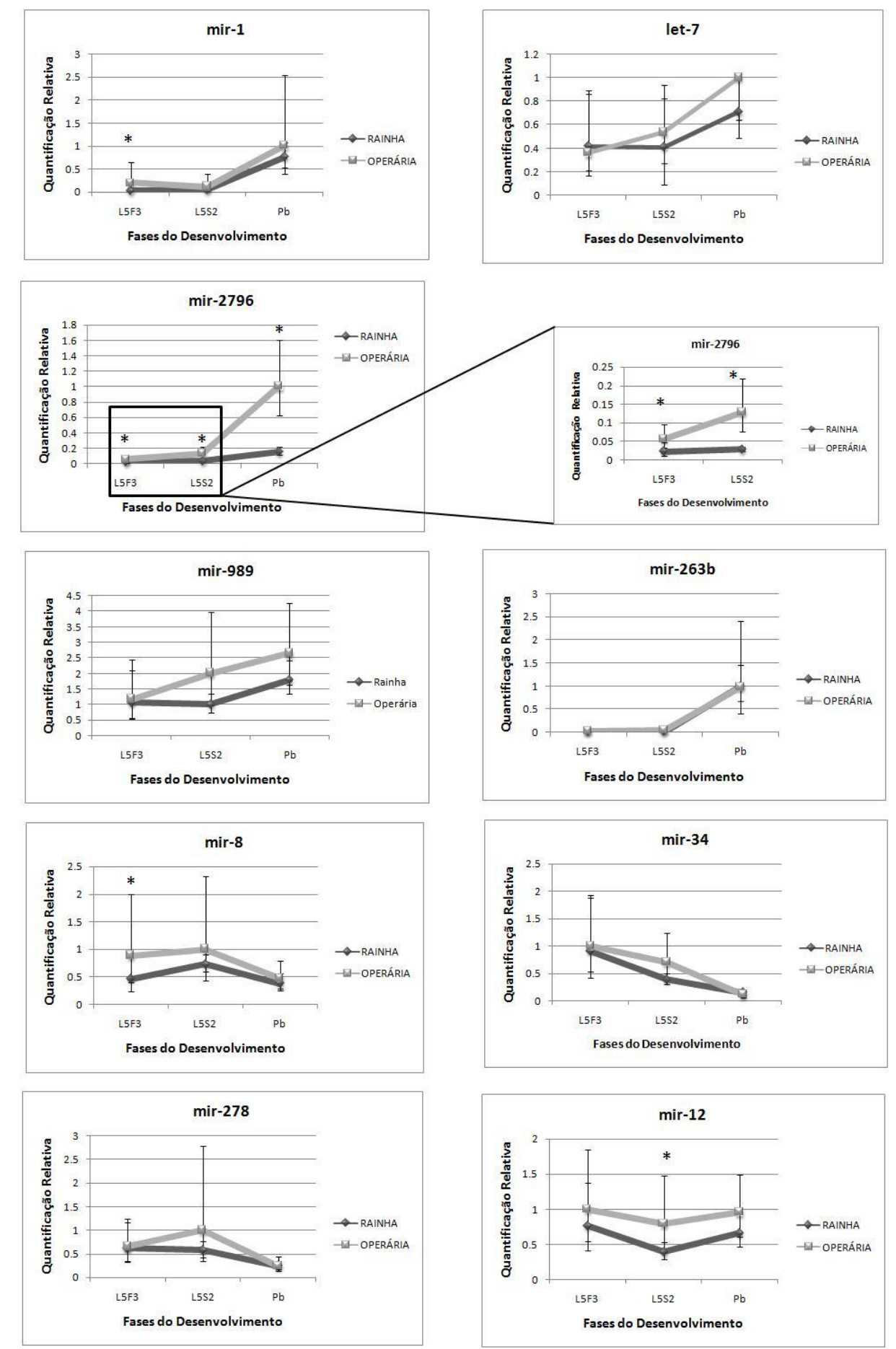

Figura 1: Quantificação relativa de microRNAs: ame-miR-1; ame-miR-263b; ame-miR-2796; ame-miR-989; ame- miR-8; amemiR-12; ame-let-7; ame-miR-278 e ame-miR-34; em rainhas e operárias de Apis mellifera nas fases L5F3 (5 instar larval - fase de alimentação 3), S2 (5' instar larval - fase de spinning 2) e Pb (pupa de olho marrom). Os valores obtidos para o pequeno RNA nuclear U6 foram utilizados para normalização. Os dados de cada grupo correspondem à expressão da média de 3 amostras para cada casta em cada fase do desenvolvimento, e as linhas representam o desvio padrão das amostras, obtido de acordo com o que foi proposto por Livak \& Schmittgen (2001). Asteriscos representam diferença estatística significativa de acordo com Teste MannWhitney $(\mathrm{p}<0,05)$ entre as amostas tratadas e controle. 
Tabela 1: Genes diferencialmente expressos entre rainhas e operárias compartilhados entre os resultados obtidos neste trabalho e aqueles encontrados por Barchuk et al. (2007). Destacados em cinza escuro: genes preferencialmente expressos em rainhas; destacados em cinza claro: genes diferencialmente expressos em operárias de acordo com os resultados dos dois trabalhos; destacados sem preenchimento: genes preferencialmente expressos em rainhas de acordo com Barchuk et al. (2007), mas preferencialmente expressos em operárias de acordo com o presente trabalho. Função biológica determinada de acordo com o banco de dados disponível no FlyBase (www.flybase.org)

\begin{tabular}{|c|c|}
\hline GB - nome do gene & Função Biológica \\
\hline GB17384 & Desconhecida \\
\hline GB11403 & Desconhecida \\
\hline GB12033 & Desconhecida \\
\hline GB12215 - DnaJ-like-2 (Droj2) & Neurogênese \\
\hline $\begin{array}{c}\text { GB14059 - Nucleosome assembly protein } 1 \\
\text { (Nap1) }\end{array}$ & $\begin{array}{c}\text { Regulação da transcrição, dependente de DNA; } \\
\text { montagem do nucleossomo }\end{array}$ \\
\hline GB14193 TweedleE $\backslash$ TwdlE & Formação da cutícula \\
\hline GB19085 - pdgy & $\begin{array}{c}\text { Catabolismo de ácidos graxos e triglicerídeos, } \\
\text { biossíntese de acetil-CoA, regulação negativa da via de } \\
\text { sinalização do receptor de insulina }\end{array}$ \\
\hline GB19712 - Shawn & Transporte \\
\hline GB15978 & Transporte intracelular de proteínas \\
\hline $\begin{array}{l}\text { GB16184 - Acyl-CoA synthetase long-chain } \\
\text { (Acsl) }\end{array}$ & $\begin{array}{l}\text { Direcionamento axonal, regulação positive do } \\
\text { sequestro de triglicerídeos, desenvolvimento do } \\
\text { sistema nervoso }\end{array}$ \\
\hline $\begin{array}{c}\text { GB11456 - Cellular Repressor of E1A-stimulated } \\
\text { Genes (CREG) }\end{array}$ & Regulação negative da transcrição \\
\hline GB11814 & Desconhecida \\
\hline GB15002 & Fosforilação de proteínas \\
\hline GB16686 & Desconhecida \\
\hline GB16903 & Morte celular autofágica, \\
\hline GB17380 - failed axon (fax) & Axogenêse \\
\hline GB17444 - Mucin 91C & Neurogenêse \\
\hline GB17541 & Regulação positiva da apoptose \\
\hline GB17793 - Сур9f2 & Desenvolvimento do disco imaginal de asa \\
\hline GB18004 & Processos metabólicos do piruvato \\
\hline GB19030 & Processos metabólicos envolvendo aldeído \\
\hline
\end{tabular}




\section{Hormonal regulation of $E c R$ gene expression during post-embryonic} development in honeybee castes

Aline C. Aleixo Silva ${ }^{1}$, Tathyana R.P. Mello ${ }^{1}$, Angel Roberto Barchuk ${ }^{2}$, Zilá L.P. Simões ${ }^{3}$

${ }^{1}$ Depto. Genética, Faculdade de Medicina de Ribeirão Preto, Universidade de São Paulo, Av.

Bandeirantes 3900, Cep. 14049-900, Ribeirão Preto, São Paulo, Brazil

${ }^{2}$ Depto. Biologia Celular, Tecidual e do Desenvolvimento, Instituto de Ciências Biomédicas, Universidade Federal de Alfenas, UNIFAL-MG, Rua Gabriel Monteiro Silva 714, Cep. 37130-000, Alfenas, Minas Gerais, Brazil

${ }^{3}$ Depto. Biologia, Faculdade de Filosofia, Ciências e Letras de Ribeirão Preto, Universidade de São Paulo, Av. Bandeirantes 3900, Cep. 14049-901, Ribeirão Preto, São Paulo, Brazil

Corresponding author: A.C. Aleixo Silva

alinea@usp.br

aleixoac@gmail.com

\section{Keywords:}

Apis mellifera; caste; ecdysone receptor, ecdysterois, juvenile hormone. 


\begin{abstract}
Insects' development, metamorphosis, reproduction and aging are controlled by a large number of factors that include two main hormones: 20-hydroxyecdysone (20E) and juvenile hormone (JH). 20E molecular action is well defined in Drosophila melanogaster. It binds to ecdysone receptor (EcR) which forms a heterodimer with ultraspiracle (USP). EcR may also act as a homodimer in some arthropods. Both EcR and USP are members of the nuclear receptor (NR) superfamily. Here we describe two transcript isoforms of Apis mellifera EcR: EcR-A and EcR-B. They differ in the Nterminal domain and in their expression profiles. While $E c R-A$ is the predominant isoform in postembryonic development, $E c R-B$ has higher transcript levels in embryos. Further studies may show if it is as result of changes in transcription machinery affinity after larval eclosion or if $E c R-B$ is maternally transported to oocytes during embryogenesis. In larval and pupal development, $E c R-B$ seems to be basally and constitutively expressed while $E c R-A$ presents a profile which is higher in workers than queens and seems to be antiparallel to hormonal levels most of the development. Expression profiles and the results of hormonal treatments suggest that low concentrations of $20 \mathrm{E}$ induce EcR expression, whereas higher titers of it inhibit the expression of both isoforms. Application of JH also led to a decrease in EcR transcripts in most cases, but a slight increase was observed in some cases in workers, which might explain this caste's higher levels of EcR-A in larvae an pupae related to queens. Our results suggest that $E c R$ isoforms have different roles in A. mellifera development. New studies are been conducted in order to elucidate hormonal regulation of this NR, specifically the role of makisterone A, which is probably the major ecdysteroid compound in bees prepupal hemolymph.
\end{abstract}




\section{Introduction}

Metamorphosis is an important process that involves, in insects, destruction of larval tissues and their substitution by adult tissues, which in most of cases, are extremely different from the old ones (Gilbert, 1994). In those animals the process of metamorphosis is under hormonal control, mainly the morphogenetic hormones ecdysteroids, represented by 20-hydroxy-ecdysone (20E) and juvenile hormone (JH) (Nijhout, 1994; Riddiford, 1994; Lan et al., 1999). JH and 20E are highly versatile hormones, coordinating development, growth, reproduction and aging in insects. Pulses of 20E provide key signals for initiating developmental and physiological transitions, while $\mathrm{JH}$ promotes or inhibits these signals in a stage-specific manner (Flatt et al., 2008). In general, morphogenetic hormones act through nuclear receptors binding. Hormone-regulated nuclear receptors (NRs) are hormone response elements crucial for the coordination of biological processes underlying reproduction, metabolism and development in animals (Richards, 1981) regulating gene expression (Truss and Beato, 1993; Cherbas, 1993). NRs proteins, in general, are subdivided into four independent but interacting functional modules called domains. $\mathrm{A} / \mathrm{B}$ is a highly variable modulator of gene expression domain. The second one, $\mathrm{C}$ domain, is DNA-binding domain (DBD). D or hinge domain provides a link between DBD and the next domain, LBD, a multifunctional domain that mediates ligand binding, dimerization, interaction with heat shock proteins, nuclear localization, and transactivation functions. (Evans, 1988; Green \& Chambon, 1988; Beato, 1989; Mangelsdorf et. al. 1995; Giguère, 1999). Functional NRs form homodimers and/or heterodimers that recognize specific DNA sequences to play their main role i) as repressors in the absence of a ligand molecule and maintain target gene inhibition by co-repressor complexes or ii) as activators of the target genes, in the presence of hormone, recruiting co-activator proteins and displacing co-repressors (Chawla et al. 2001; King-Jones and Thummel 2005; Mangelsdorf and Evans 1995).

The ecdysteroid receptor is a heterodimeric NR formed by ecdysone receptor $(E c R)$ and ultraspiracle (usp) genes products. usp is an ortholog of vertebrates retinoid-X receptor (RXR) (Yao et al., 1992, 1993), considered at first as an orphan NR, but some studies have suggested it as a JH receptor, besides acting as part of ecdysteroid receptor (Xu et al., 2002; Barchuk et al., 2004), and indicating a cross-talk between ecdysteroid and JH action (Bitra and Palli, 2009). In Drosophila, EcR gives rise to three different isoforms, $E c R$-A, $E c R$-B1 e $E c R$-B2 (Yao et al., 1993; Talbot,1993), differentially expressed in a tissue- and stage-specific manner (Robinow et al., 1993; Truman et al., 1994). It acts through ecdysone binding regulating an auto-regulatory pathway that promotes an increase of its protein in response to the ligand (Grebe et al., 2003; Lezzi et al., 2002) and stimulates gene expression networks stimulated by those hormones and EcR-dependent (Beckstead et al., 2005; Gauhar et al., 2009).

Here we identified two Apis mellifera EcR isoforms, which showed to be very similar in their nucleotide and amino acid contents, except by the $\mathrm{N}$-terminal region of the protein that encodes $\mathrm{A} / \mathrm{B}$ 
domain. Their expression profiles in queens and workers development presented significant differences, especially when the levels of each isoform were compared. We also found differences in those levels related to caste in specific developmental points. Surprisingly, artificially increased titers of morphogenetic hormones $20 \mathrm{E}$ and $\mathrm{JH}$, cause EcR-A and EcR-B levels to decrease, indicating an antiparallel regulation by the levels of these hormones. Taken together, these results suggest a complex regulation of EcR, related to caste- and stage-specific levels of EcR each isoform.

\section{Materials and Methods}

\subsection{Bioinformatics}

The putative $E c R$ gene was identified in the A. mellifera genome by homology-based searches using tools from University of São Paulo at http://zulu.fmrp.usp.br/beelab/bioinfo_blast, National Center for Biotechnology Information (http://www.ncbi.nlm.nih.gov) and Honeybee Genome Database, Baylor College of Medicine (http://www.hgsc.bcm.tmc.edu/projects/honeybee/). Manual annotation of EcR gene was carried out using Artemis platform (http://www.sanger.ac.uk/Software/Artemis/) with a previously known expressed sequence tag for EcR protein (GenBank accession number AB095514) and a cDNA fragment cloned and sequenced in our laboratory. Phylogenetic tree was obtained by Maximum Parsimony method with bootstrap re-sampling using ClusltalW-aligned sequences (http://align.genome.jp/) in MEGA3.1 software (Kumar et al., 2004).

\subsection{Bees and hormone treatments}

Honeybee embryos, larvae and pupae were obtained from A. mellifera colonies (Africanized hybrids) maintained at the Experimental Apiary of the University of São Paulo at Ribeirão Preto, Brazil as reported previously (Barchuk et al., 2008). The developmental stages were classified according to Michelette and Soares (1993; see Table 3), considering eye color and absence or presence and intensity of cuticle pigmentation. At the appropriate time, pupae were immersed in TRIzol reagent (Invitrogen Life Technologies) and frozen at $-80^{\circ} \mathrm{C}$ until RNA extraction.

For the analysis of $E c R$ expression response to artificially augmented levels of hormones, brown-eyed, unpigmented cuticle pupae $(\mathrm{Pb})$ were removed from the brood frames and maintained in an incubator at $34^{\circ} \mathrm{C}$ and $80 \%$ relative humidity. At least three groups of 3-7 pupae were injected $5 \mu \mathrm{g}$ of 20 hydroxyecdysone (20E; Sigma; in $2 \mu \mathrm{L}$ of ethanol-Ringer solution $12.5 \%$ ) or topically-applied $10 \mu \mathrm{g}$ of juvenile hormone III (JH-III; Fluka, in $2 \mu \mathrm{L}$ acetone), and the RNA samples from fat bodies were obtained after 1, 12, 24 and $48 \mathrm{~h}$ (independent experiments). Control pupae received $2 \mu \mathrm{L}$ of the respective solvents. The amount of applied hormone was based on our previous experiments in which we examined the hormonal induction of gene expression during pupal development (Barchuk et al., 
2002, 2004). Fat bodies were obtained after practicing a longitudinal incision in isolated pupa abdomen and keeping it in Petri dishes with $\mathrm{NaCl} 0.9 \%$ and gently agitation. The resultant suspension of dispersed fat body cells was centrifuged during $1 \mathrm{~min}$ and $2500 \mathrm{~g}$ and, like the entire individuals (embryos, larvae and pupae), transferred into TRIzol reagent and frozen at $-80^{\circ} \mathrm{C}$ until RNA extraction. We used fat bodies because it would allow a contribution to the knowledge of its biology, especially regarding the mechanism controlling $v g$ expression in honeybees.

\subsection{RNA extraction and quantitative RT-PCR ( $q P C R)$ assays}

Total RNA was extracted according to the Invitrogen's protocol, followed by column purification (RNeasy Mini Kit, QIAGEN) as described previously (Barchuk et al. 2004, 2007). First strand cDNA was synthesized from $2 \mu \mathrm{g}$ of RNA with SuperScript II Reverse Transcriptase and an oligo $\left(\mathrm{dT}_{12-18}\right)$ primer (Invitrogen). Comparative analyses of transcription levels were performed by Real Time quantitative PCR using a 7500 Real-Time PCR System (Applied Biosystems). Amplifications were carried out in a $20-\mu \mathrm{L}$ reaction mixture containing $10 \mu \mathrm{L}$ of SYBR ${ }^{\circledR}$ Green Master Mix $2 \mathrm{x}$ (Applied Biosystems), $0.8 \mu \mathrm{L}$ of $10 \mathrm{mM}$ of each gene specific forward and reverse primers and $1 \mu \mathrm{L}$ of firststrand cDNA samples diluted (1/5) in water (EcRA-F: CCAACAGCAACAACGGCTAC, EcRB-F: ACAGTGTTGCCAACGGTCAC, EcRA/B-R: AAAGAGCCAGGCTGCGACAA， rp49-F: CGTCATATGTTGCCAACTGGT, rp49-R: TTGAGCACGTTCAACAATGG). Reaction conditions were $50^{\circ} \mathrm{C}$ for $2 \mathrm{~min}, 95^{\circ} \mathrm{C}$ for $10 \mathrm{~min}$, followed by 40 cycles of $95^{\circ} \mathrm{C}$ for $15 \mathrm{~s}$, and $60^{\circ} \mathrm{C}$ for $1 \mathrm{~min}$. Three biological replicates were run in three technical replicates. $\beta$-actin gene (GenBank accession number AB023025) and RP-49 (GenBank accession number AF441189; both genes were partially sub-cloned and sequenced in our laboratory) were used as reference. Relative quantities of transcripts were calculated using the comparative Ct method (Applied Biosystems, User bulletin\#2). Statistical analyses were carried out with Statistica version 7.0 (http://www.statsoft.com).

\subsection{Northern blot analysis}

Approximately $15 \mu \mathrm{g}$ of total RNA extracted from queens and workers PP1 and Pb were subjected to $1.5 \%$ agarose/formaldehyde gel electrophoresis, and the RNA was then transferred to membrane using a VacuGene XL Vacuum Blotting (GE Healthcare) system. A cDNA fragment of 160bp encoding the 3' part of the DNA-binding domain was used for probe synthesis (Random Primers DNA Labeling System Invitrogen, Redivue ${ }^{32} \mathrm{P}$-Nucleotides). After $3 \mathrm{~h}$ of hybridization $\left(42^{\circ} \mathrm{C}\right)$, membranes were washed during $20 \mathrm{~min}$ with SSC $0.1 \mathrm{X} / 0.1 \% \mathrm{SDS}$, and autoradiographed (Super Sensitive ST film revealed with Cyclone ${ }^{\mathrm{TM}}$ Storage Phosphor System, PerkimElmer ${ }^{\circledR}$ ). 


\section{Results}

\subsection{EcR-A and EcR-B transcript variants identification in honeybees}

There have been sequenced two transcript variants of the EcR gene in Apis mellifera, EcR-A (Accession numbers NM_001098215, XM_394760) and EcR-B (NM_001159355). They are 2,635 nt and 2,782 nucleotide long, respectively (see also Takeuchi et al., 2007 and Watanabe et al., 2010). As can be inferred from Dr. Kubo's group previous studies, this difference in nucleotide length resides within the 5 ' end and results in differences in the number and identity of amino acids of the Nterminal that gives rise to the modulator $\mathrm{A} / \mathrm{B}$ domain. A conceptual translation of the nucleotide sequences showed a putative EcR-A protein containing 620 amino acids and EcR-B with 557 amino acids, both sharing a 452 amino acid sequence to the carboxy terminal (Figure 1). Both variants run almost at the same rate in agarose gel (data not shown)/Northern blotting (Figure 2). As it can be seen, workers and queens at PP1 and workers at $\mathrm{Pb}$ stages presented one hybridization band, of approximately 2,7kb, while queens at $\mathrm{Pb}$ show a slightly shorter band (since we did not aimed at quantification, the respective bands density does not represent differences in transcription levels). This result suggests transcripts have small differences in length and supports the in silico evidence.

\subsection{Developmental profile of AmEcR transcript variants $A$ and $B$}

By quantitative real time PCR (qPCR) assays we show that both transcript variants of $A m E c R$ gene are transcribed during honeybee castes development (Figure 3). However, row $\mathrm{Ct}$ data and the relative transcription profiles (Figure 3) indicate that EcR-A RNA is produced in relatively higher levels during post-embryonic development, when compared to EcR-B levels. This EcR variant, EcR-B, is expressed in basal levels during most of the developmental stages studied in queens and workers. Embryonic stage was the only developmental phase in which significant AmEcR-B transcription levels could be observed. For this developmental stage, EcR-B expression levels were significantly higher than EcR-A levels $(P<0.05$ Mann-Whitney Test). Another developmental stage where we could observe higher AmEcR-B transcription levels is PP3.

EcR-A transcripts synthesis is basal in embryos and during the first three larval instars in both castes. From the third instar larvae stage (L3) on, EcR-A transcripts showed similar transcription profile in castes, but presenting higher levels in workers (Figure 2). The main transcription levels occur in the fifth larvae stage - spinning phase (L5S1 and L5S3) and showed to be significantly different in queens and workers $(P<0.05$ Mann-Whitney Test). A decrease to lower levels is observed in pre-pupal phase 1 and 2 (PP1-PP2) for both castes. After then, in PP3, workers present increasing EcR-A levels, but in lower rates, that is slightly kept until the emergence of the adult. In queens, on the other hand, the synthesis of this molecule turns basal from early pupal phase on, 
showing statistical difference when compared to workers in Pbm, Pdb and NE stages $(P<0.05$ Mann-Whitney Test).

\subsection{Transcriptional response of AmEcR to artificially augmented ecdysteroid and JH titers}

The application of $20 \mathrm{E}$ and $\mathrm{JH}$ to worker and queen bees during pupal development, after the physiological peak of ecdysteroids, in general, promoted a transcriptional repression of both EcR variants, which showed to be significant at $24 \mathrm{~h}$ of $20 \mathrm{E}$ treatment for EcR-A and EcR-B in queens and EcR-B in workers; at $24 \mathrm{~h}$ of $\mathrm{JH}$ treatment for EcR-A, and $1 \mathrm{~h}$ for EcR-B in queens $(P<0.05$ Mann-Whitney U Test; Figure 4). The exception was the apparent induction of EcR transcription after JH treatment in workers (Figure 4B), at least at $1 \mathrm{~h}$ of treatment for EcR-A, and $12 \mathrm{~h}$ after it for EcR-B $(P<0.05$ Mann-Whitney Test $)$.

\section{Discussion}

Northern Blot analysis show hybridization with two similar bands, containing approximately 2.6 or $2.7 \mathrm{~kb}$ that as found to other species including Tenebrio molitor (Mouillet et al., 1997) and Drosophila melanogaster (Yao et al., 1993; Talbot,1993), suggesting that, like in these species, AmEcR is a single copy gene that originates two different isoforms. Here we found that $A m E c R$ isoforms are similar in their nucleotide and amino acid structure, except by an $\mathrm{N}$-terminal region that forms the variable $\mathrm{A} / \mathrm{B}$ modulator domain. We also observed that both are expressed during queens and worker development, but EcR-A showed higher levels than EcR-B in most of developmental phases but embryos. When comparing both isoforms in castes, it could be noted that workers in general presented higher levels than queens. Besides that, $A m E c R$ expression levels for both variants seem to follow anti-parallel patterns with morphogenetic hormones. The variation observed in the transcripts variants length can be related, as it is seen in a large number of nuclear receptors, to alternative splicing, different promoters, and distinct translational start sites to generate different modulator domains (Giguère, 1994; Chambon, 1996). The A/B domain usually modulates transcriptional activation, and it was demonstrated that the modulator domains possess promoter- and cell context-dependent activities (Tora et al., 1988; Berry et al., 1990; Vegeto et al., 1993), although they confer similar properties to distinct receptors (Kato et al., 1995; Bunone et al., 1996; Tremblay et al., 1997).

According to expression profile of EcR transcripts variants in queens and workers development, we observed lower levels of EcR-B compared to EcR-A levels, except by embryonic phase. These findings may indicate RNA polymerase II and its transcription machinery may have higher affinity for the second consensus sequence for the transcription initiation during embryonic development, giving rise to EcR-B. That condition apparently changes after larvae eclosion, during the post-embryonic 
phase, towards to EcR-A transcription. Another plausible hypothesis is that $A m E c R-B$ mRNA is maternally transported to the oocytes to be used during early embryogenesis, what doesn't occur for the other isoform.

Queens and workers presented similar expression profiles for both, EcR-A and $E c R-B . E c R-B$ seems not to favor caste differential development since its levels are basal, probably constitutive and doesn't seem to be modulated by morphogenetic hormones titers, during the whole post-embryonic development, what was also seen in Drosophila melanogaster (Sullivan and Thummel, 2003). EcR-A may play an important role in this process, because it showed to be preferentially expressed in workers for most of developmental stages analyzed. This contrasts with another study in which EcR-A is up regulated in queens (Takeuchi et al., 2007). These contrasting results can be due to different tissues used for each study, suggesting a tissue- caste-specific pattern of expression of this gene and its related transcripts variants. Besides that, differences in caste profiles may demonstrate differences inherent to caste development related to distinct patterns of gene expression that determine differences in developmental timing, morphology, physiology and behavior (Michelette and Soares, 1993; Severson et al., 1989; Corona et al., 1999; Evans and Wheeler, 1999; 2001; Hepperle and Hartfelder, 2000; Guidugli et al., 2004; Corona et al., 2005, Barchuk et al., 2007; Maleszka, 2008). The main levels of EcR-A transcripts were found later to critical period of caste determination, in L5S workers. This peak is in accordance to the ecdysteroid and juvenile hormone titers found during this stage. They are relatively high for both (Rembold, 1987; Rachinsky et al., 1990), and can be acting synergistically to activate EcR-A transcription in this specific time point. During $5^{\text {th }}$ larval stage, profound changes occur in response to differential nutrition in each caste (Goewie, 1978; Nijhout, 1994; Barchuk, et al., 2007), suggesting that EcR-A can be part of the mechanism that culminates in caste differentiation. On the other hand, ecdysteroids appear not to play the same incremental role in $E c R-A$ transcription during pupal stage, where they show the highest titers, contrasting to low levels of $E c R-A$. Similar results were described for Manduca sexta, when low concentrations of 20E induced EcR expression while higher titers of this hormone repressed the expression of this gene (Jindra et al., 1996). These results suggest that EcR gene responds positively to a slight increase in ecdysteroids, but high hormone levels are repressive. In Blatella germanica, the expression of EcR-A seems to be not regulated by $20 \mathrm{E}$, by treatment with $20 \mathrm{E}$ an antagonist levels of this hormone and EcR-A transcripts were observed (Pascual et al., 1992; Cruz et al., 2006). It was also presented in our findings related to artificially increasing $20 \mathrm{E}$ e JH levels. In most cases an anti-parallel regulation, where ecdysteroids repress both isoforms transcription in queens and workers, mainly after $24 \mathrm{~h}$ of hormone treatment.

The differences presented by EcR-A in specific developmental time points in response to ecdysteroids can be due to the presence of makisterone A and/or 20E. According to some studies, Makisterone A is probably the major ecdysteroid compound in prepupal hemolymph, while $20 \mathrm{E}$ appeared to be the second most important compound (Rachinsky et al., 1990), so they can be acting in a diverse manner in order to regulate EcR gene expression, even binding only one of the isoforms or modulating their 
transcription in a different way. Another possible explanation is the diversification of hormone function with $20 \mathrm{E}$ having retained its involvement in reproductive physiology, as suggested by Takeuchi et al. (2007) and makisterone A having evolved to act governing post-embryonic development, as indicated for Dysdercus fasciatus (Feldlaufer et al., 1991). And as seen by Elias-Neto et al. (2010) ecdysteroids can be synthesized in different organs in specific developmental stage which can be involved to specific $E c R$ - $A$ expression pattern. Similarly to ecdysteroids, JH seemed to repress EcR levels in queens, but in workers $E c R-B$ transcription is activated by this hormone. Natural high level of JH showed to stimulate phisiometabolic genes in queens, and JH-treated workers (Barchuk et al., 2007), so we can assume that EcR-is not one of those genes and is probably down regulated by one of them, acting as part of a gene expression network JH-dependent. EcR forms with USP the heterodimeric molecule, responsible for binding ecdysteroids (Yao et al., 1992, 1993). Since usp is suggested as JH ligand (Chung et al., 1998; Barchuk et al., 2004) and it also originates two different transcritpts (Barchuk et a,. 2004), it may influence EcR transcription, in a isoform-dependent manner, adittionally it was seen that the nuclear localization of EcR is determined by USP (Dutko-Gwóźdź et al.,2008). Taken together these findings suggest EcR plays distinct roles during larval-pupal metamorphosis in an isoform dependent-manner, acting distinctly depending on hormonal environment and differential gene expression tissue- and caste-specific. We are working on some other issues trying to find out the nature of some of encountered differences and in a near future we hope to better explain them.

\section{Acknowledgements}

Dr. Nilce M.M. Rossi, Roseli de Aquino P. Ferreira and Diana Gras for lab facility and support in Northern blotting assays. Luiz Aguiar, for support in field work.

Financial support: Fapesp (processo 2008/01446-4 and 2008/10757-3) 


\section{Literature cited}

Barchuk, A. R.; Bitondi, M. M.G.; Simões, Z. L. P. (2002). Effects of juvenile hormone and ecdysone on the timing of vitellogenin appearance in hemolymph of queen and worker pupae of Apis mellifera. Journal of Insect Science, 2: 1-8.

Barchuk, A. R.; Maleszka, R.; Simões, Z. L.P. (2004). Apis mellifera ultraspiracle: cDNA sequence and rapid up-regulation by juvenile hormone. Insect Mol Biol. 13:459-467.

Barchuk, A.R.; Cristino, A.S.; Kucharski, R.; Costa, L.F.; Simões, Z.L.; Maleszka, R. (2007) Molecular determinants of caste differentiation in the highly eusocial honeybee Apis mellifera. BMC Dev Biol, 7:70-89.

Barchuk, A.R.; Figueiredo, V.L.C.; Simões, Z.L.P. (2008) Downregulation of ultraspiracle gene expression delays pupal development in honeybees. J Insect Physiol, 54:1035-1040.

Beato, M. (1989). Gene regulation by steroid hormones. Cell 56:335-344.

Beckstead, R.B.; Lam, G.; Thummel, C.S. (2005). The genomic response to 20-hydroxyecdysone at the onset of Drosophila metamorphosis. Genome Biology 6:R99.

Berry, M.; Metzger, D.; Chambon, P. (1990) Role of the two activating domains of the oestrogen receptor in the cell-type and promoter context dependent agonistic activity of the anti-oestrogen 4-hydroxytamoxifen. EMBO J, 9:2811-2818.

Bitra, K.; Palli, S.R. (2009) Interaction of proteins involved in ecdysone and juvenile hormone signal transduction. Arch Insect Biochem Physiol,70(2):90-105.

Bunone, G.; Briand, P-A.; Miksicek, R.J.; Picard, D. (1996) Activation of the unliganded estrogen receptor by EGF involves the MAP kinase pathway and direct phosphorylation. EMBO J, 15:2174-2183.

Chambon, P. (1996) A decade of molecular biology of retinoic acid receptors. In: Whelan WJ (ed) The Retinoid Revolution. FASEB J 10:940-954.

Chawla, A.; Repa, J.J.; Evans, R.M.; Mangelsdorf, D.J. (2001) Nuclear receptors and lipid physiology: opening the X-files. Science, 294(5548):1866-70.

Cherbas, P. (1993) The IVth Karlson Lecture: Ecdysone-responsive genes. Biochem. Mol. Biol., 23: 3-12.

Chung, A.C.K.; Durica, D.S.; Clifton, S.W.; Roe, B.A.; Hopkins, P.M. (1998) Cloning of crustacean ecdysteoid receptor and retinoid-X receptor gene homologs and elevation of retinoi-X receptor mRNA by retinoic acid. Mol Cell Endocrinol 139:209-227.

Corona, M.; Estrada, E.; Zurita, M. (1999) Differential expression of mitochondrial genes between queens and workers during caste determination in the honeybee Apis mellifera. J Exp Biol, 202:929-938.

Corona, M.; Hughes, K.A.; Weaver, D.B.; Robinson, G.E. (2005) Gene expression patterns associated with queen honey bee longevity. Mech Ageing Dev, 126(11):1230-8.

Cruz, J.; Mané-Padrós, D.; Bellés, X.; Martín, D. (2006) Functions of the ecdysone receptor isoform-A in the hemimetabolous insect Blattella germanica revealed by systemic RNAi in vivo. Dev Biol, 297:158-171.

Dutko-Gwóźdź J, Gwóźdź T, Orłowski M, Greb-Markiewicz B, Duś D, Dobrucki J, Ozyhar A. (2008) The variety of complexes formed by EcR and Usp nuclear receptors in the nuclei of living cells. Mol Cell Endocrinol, 294(1-2):45-51. 
Elias-Neto, M.; Michelle P.M. Soares, Zilá L.P. Simões, Klaus Hartfelder, Márcia M.G. Bitondi (2010) Developmental characterization, function and regulation of a Laccase 2 encoding gene in the honey bee, Apis mellifera (Hymenoptera, Apinae). Insect Biochem Mol Biol, 40:241-251.

Evans, R. M. (1988). The steroid and Thyroid hormone receptor Superfamily. Science, 240: 889-895.

Evans, J.; Wheeler, D. (1999) Differential gene expression between developing queens and workers in the honey bee, Apis mellifera. Proc. Natl. Acad. Sci. USA, 96:5575-5580.

Feldlaufer, M.F.; Weirich, G.F.; Lusby, W.R.; Svoboda, J.A. (1991) Makisterone C a 29-carbon ecdysteroid from developing embryos of the cotton stainer bug, Dysdercus fasciatus. Arch Insect Biochem Physiol, 18(2):71-79.

Flatt, T.; Heyland, A.; Rus, F.; Porpiglia, E.; Sherlock, C.; Yamamoto, R.; Garbuzov, A.; Palli, S.R.; Tatar, M.; Silverman, N. (2008) Hormonal regulation of the humoral innate immune response in Drosophila melanogaster. J Exp Biol, 211:2712-2724.

Gauhar, Z.; Sun, L.V.; Hua, S.; Mason, C.E.; Fuchs, F.; Li ,T-R.; Boutros, M.; White, K.P. (2009) Genomic mapping of binding regions for the Ecdysone Receptor protein complex. Genome Res, 19(6):100613.

Giguère, V. (1994) Retinoic acid receptors and cellular retinoid binding proteins: complex interplay in retinoid signaling. Endocr Rev 15:61-79

Giguère, V. (1999). Orphan Nuclear receptors: from gene to function. Endocrine Reviews, 20(5):689-725.

Gilbert, S. F. (1994). Developmental Biology. $4^{a}$ edição. Sinauer, USA.

Goewie, E. A. (1978) Med. Landbouwhogeschool. Wageningin, 75:1-75.

Grebe, M.; Przibilla, S.; Henrich, V.C.; Spindler-Barth, M. (2003). Characterization of the ligand binding domain of the ecdysteroid receptor from Drosophila melanogaster. Biol. Chem. 384,105-116

Green, S.; Chambon, P. (1988). Nuclear receptors enhance our understanding of transcription regulation. Trends Genet, 4: 309-314.

Guidugli, K.R.; Hepperle, C.; Hartfelder, K. (2004) A member of the short-chain dehydrogenase/reductase (SDR) superfamily is a target of the ecdysone response in honey bee (Apis mellifera) caste development Apidologie, 35:37-47.

Hartfelder, K. (2000) Insect juvenile hormone: from "status quo" to high society. Braz J Med Biol Res, 33(2): 157-177.

Hepperle, C.; Hartfelder, K. (2000) Differential display PCR reveals ecdysteroid-responsive genes in the ovary of honeybee worker larvae. In Proceedings of the International Congress of Entomology. Edited by Gazzoni D. Londrina, Brazil: Embrapa Press, 552.

Jindra, M.; Malone, F.; Hiruma, K.; Riddiford, L.M. (1996). Developmentl profiles and edysteroid regulation of the mRNAs for two edysone receptor isofroms in the epidermis and wings of the tobacco hornworm, Manduca sexta. Dev Biol, 180:258-272.

Kato, S.; Endoh, H.; Masuhiro, Y.; Kitamoto, T.; Uchiyama, S.; Sasak,i H.; Masushige, S.; Gotoh, Y.; Nishida, E.; Kawashima, H.; Metzger, D.; Chambon, P. (1995) Activation of the estrogen receptor through phosphorylation by mitogen-activated protein kinase. Science, 270:1491-1494.

King-Jones, K.; Thummel, C.S. (2005) Developmental biology. Less steroids make bigger flies. Science, 310(5748):630-1. 
Kumar, R.; Thompson, E.B. (2003). Transactivation functions of the N-terminal domains of nuclear hormone receptors: protein folding and coactivator. Mol. Endocrinol, 17:1-10.

Lan, Q.; Hiruma, K.; Hu, X.; Jindra, M. and Riddiford, L. M. (1999). Activation of a delayed-early gene encoding MHR3 by the ecdysone receptor heterodimer EcR-B1 - USP-1 but not by EcR-B1 - USP-2. Mol Cell Biol, 19:4897-4906.

Lezzi, M.; Bergman, T.; Henrich, V.C.; Vogtli, M.,; Fromel, C.; Grebe, M.; Przibilla, S.; Spindler-Barth, M. (2002). Ligand induced heterodimerization between the ligand binding domains of the Drosophila ecdysteroid receptor and ultraspiracle. Eur. J.Biochem. 269, 3237-3245.

Maleszka, R. (2008) Epigenetic integration of environmental and genomic signals in honey bees: the critical interplay of nutritional, brain and reproductive networks. Epigenetics, 3(4):188-92.

Mangelsdorf, D.J.; Thummel, C.; Beato, M.; Herlich, P.; Schütz, G.; Umesono, K.; Blumberg, B.; Kastner, P.; Mark, M.; Chambon, P. and Evans, R.M. (1995). The nuclear receptor superfamily: The second decade. Cell, 83:835-839.

Mangelsdorf, D.J.; Evans, R.M. (1995). The RXR heterodimers and orphan receptors. Cell, 83:841-850.

Michelette, E.R.F.; Soares, A.E.E. (1993) Characterization of preimaginal developmental stages in Africanized honey bee workers (Apis mellifera L). Apidologie, 24:431-440.

Mouillet, J.F.; Delbecque, J.P.; Quennedey, B.; Delachambre, J. (1997). Cloning of two putative ecdysteroid receptor isoforms from Tenebrio molitor and their developmental expression in the epidermis during metamorphosis. Eur J Biochem, 248:856-863.

Nijhout, H. F. (1994) Insects hormones. Princeton University Press, New Jersey.

Pascual, N.; Cerdá, X.; Benito, B.; Tomás, J.; Piulachs, M.D.; Bellés, X. (1992) Ovarian ecdysteroids levels and basal oocyte development during maturation in the cockroach Blattella germanica (L.). J Insect Physiol, 38:339-348.

Rachinsky, A.; Strambi, C.; Strambi, A.; Hartfelder, K. (1990) Caste and metamorphosis: hemolymph titers of juvenile hormone and ecdysteroids in last estágio honeybee larvae. Gen Comp Endocrinol, 79:31-38.

Rembold, H. (1987). Regulation of Honeybee age polyethism by juvenile hormone. Behavioral Ecology and Sociobiology, 20:329-338.

Richards, G. (1981) The radioimmune assay of ecdysteroid titres in Drosophila melanogaster. Mol Cell Endocrinol, 21: 181-197.

Riddiford, L. M. (1994). Cellular and molecular actions of Juvenile Hormone I. General considerations and premetamorphic actions. Adv Insect Physiol, 24:213-274.

Robinow, S.; Talbot, W. S.; Hogness, D. S.; Truman, J. W. (1993) Programmed cell death in the Drosophila CNS is ecdysone-regulated and coupled with a specific ecdysone receptor isoform. Development, 119:12511259.

Severson, D.; Williamson, J.; Aiken, J. (1989) Caste-specific transcription in the female honeybee. Insect Biochem, 19:215-220.

Sullivan, A.A.; Thummel, C.S. (2003) Temporal profiles of nuclear receptor gene expression reveal coordinate transcriptional responses during Drosophila development. Mol Endocrinol, 17(11):2125-2137. 
Takeuchi, H.; Paul,R.K.; Matsuzaka,E.; Kubo,T. (2007) EcR-A expression in the brain and ovary of the honeybee (Apis mellifera L.) Zool Sci, 24 (6), 596-603.

Talbot, W. S.; Swyryd, E. A.; Hogness, D. S. (1993) Drosophila tissues with different metamorphic responses to ecdysone express different ecdysone receptor isoforms. Cell, 73:1323-1337.

Tora, L.; Gronemeyer, H.; Turcotte, B.; Gaub, M.P.; Chambon, P. (1988) The N-terminal region of the chicken progesterone receptor specifies target gene activation. Nature 333:185-188.

Tremblay, G.B.; Tremblay, A.; Copeland, N.G.; Gilbert, D.J.; Jenkins, N.A.; Labrie, F.; Giguère, V. (1997) Cloning, chromosomal localization and functional analysis of the murine estrogen receptor b. Mol Endocrinol, 11:353-365.

Truman, J.W.; Talbot, W.S.; Fahrbach, S.E.; Hogness, D.S. (1994) Ecdysone receptor expression in the CNS correlates with stage-specific responses to ecdysteroids during Drosophila and Manduca development. Development, 120:219-234.

Truss, M.; Beato, M. (1993) Steroid hormone receptors: interaction with deoxyribonucleic acid and transcription factors. End. Rev., 14: 459-479.

Vegeto, E.; Shahbaz, M.M.; Wen, D.X.; Goldman, M.E.; O’Malley, B.W.; McDonnell, D.P. (1993) Human progesterone receptor $\mathrm{A}$ form is a celland promoter-specific repressor of human progesterone receptor B function. Mol Endocrinol 7:1244-1255.

Watanabe, T.; Takeuchi, H.; Kubo, T. (2010) Structural diversity and evolution of the N-terminal isoformspecific region of ecdysone receptor-A and -B1 isoforms in insects BMC Evol Biol, 10:40.

Xu, Y.; Fang, F.; Chu, Y.; Jones, D. and Jones, G. (2002) Activation of transcription through the ligandbinding pocket of the orphan nuclear receptor ultraspiracle. Eur J Biochem, 269(24): 6026 - 6036.

Yao, T.P.; Sagraves, W. A.; McKeown, M.; Evans, R.M. (1992) Drosophila ultraspiracle modulates ecdysone receptor function via heterodimer formation. Cell, 71:63-72.

Yao, T.P.; Forman, B.M.; Jiang, Z.; Cherbas, L.; Chen, J.D.; McKeon, M.; Cherbas, P. \& Evans, R. M. (1993). Functional ecdysone receptor is the product of EcR and Ultraspiracle genes. Nature, 366:476-479. 


\section{Figures}

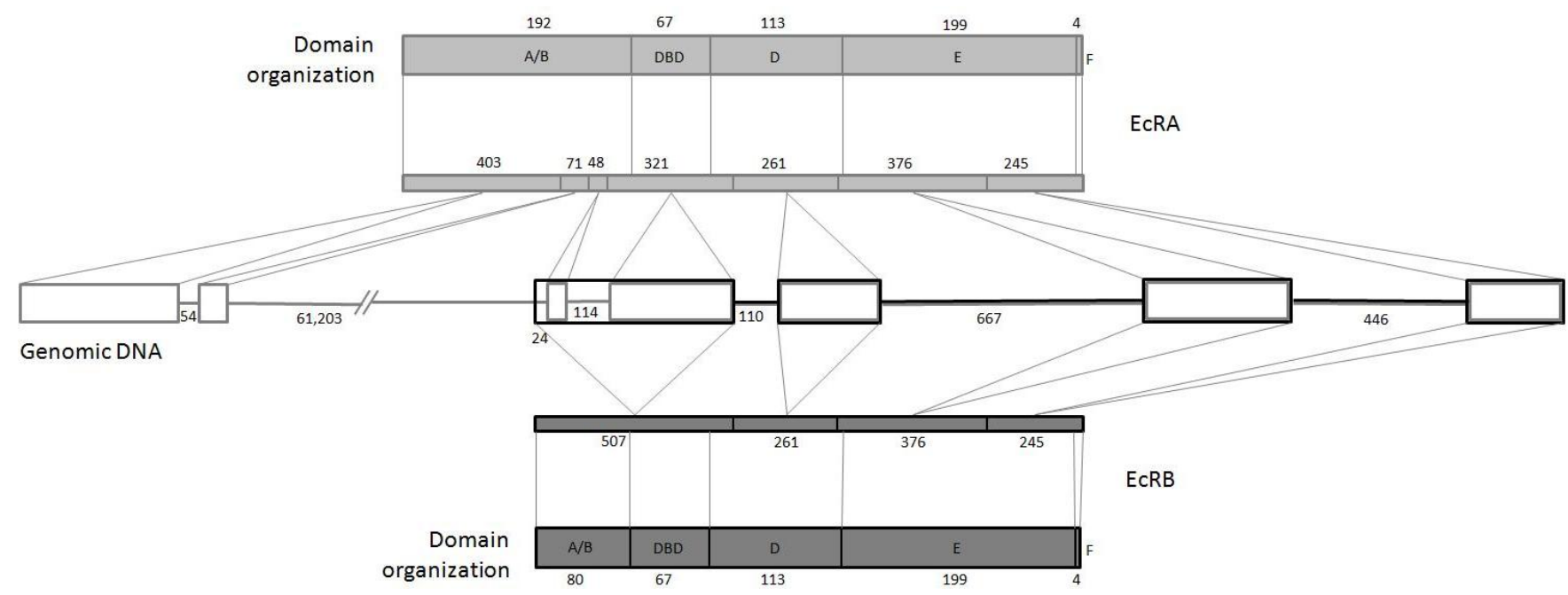

Figure 1. Gene and protein organization of honeybee EcR. A) Four exons (E1-E4 rectangles) and three introns (lines) with the respective number of nucleotides. B) The five domains of EcR protein with the respective amino acid number. The extension of coding sequences of each exon within EcR domains is marked by oblique lines. 5 ' and $\mathrm{N}$ termini are on the left.

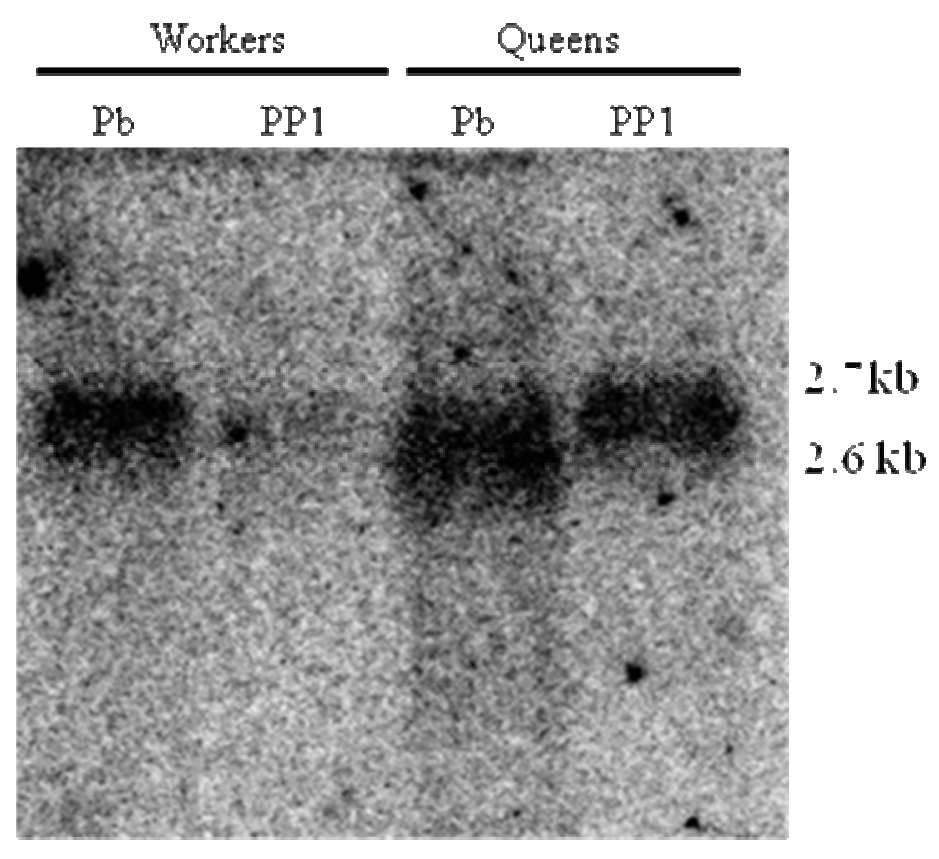

Figure 2. Northern blot showing the expression of $A$. mellifera $E c R$ in honeybees. Approximately $15 \mu \mathrm{g}$ of total RNA was used per lane. The used probe was a radioactively labeled $160 \mathrm{bp}$ fragment including part of the coding region for the DBD. PP1: fifth instar larva, Pre-Pupa 1. Pb: brown-eyed Pupa, unpigmented cuticle. EcR gives rise to one transcript of $\sim 2.6$ and in $\mathrm{Pb}$ Queens and one of $\sim 2.7 \mathrm{~kb}$ in both castes in PP1. 


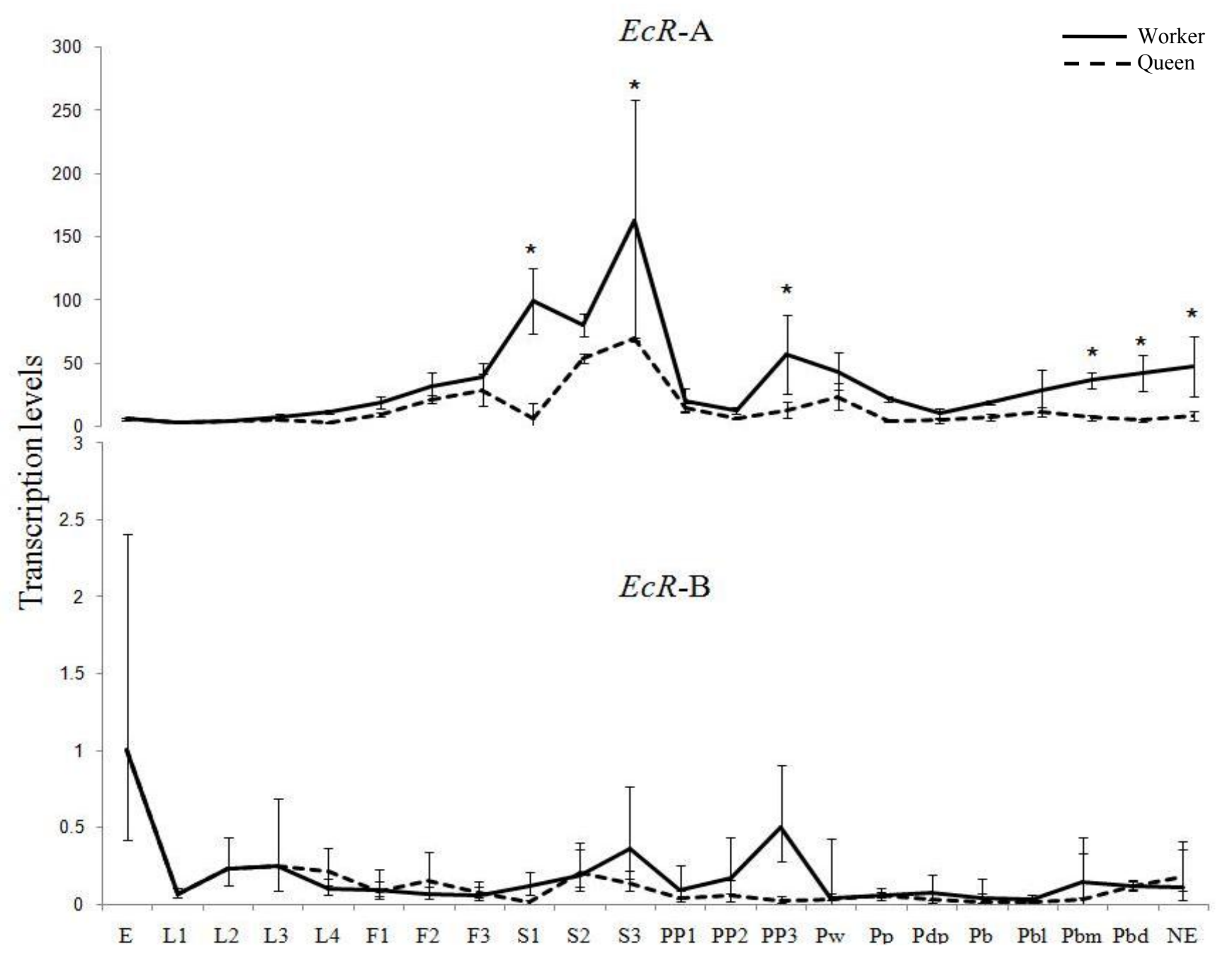

Figure 3. Developmental expression of $E c R$ gene in $A$. mellifera castes. The ordinate represents the average of the expression levels of biological triplicates, obtained by quantitative Real-Time PCR (qPCR), using ribosomal protein 49 (RP-49) to normalize. SEMs were calculated as suggested by Livak \& Schmittgen (2001) and are indicated by vertical bars. Asterisks indicate statistical difference (Mann-Whitney Test, $p<0,05$ ). See Table I for the complete name of developmental stages. 
(A)

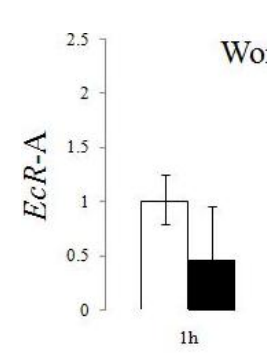

Workers/20E

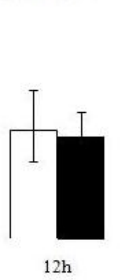

$12 \mathrm{~h}$

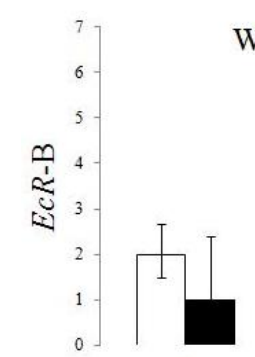

ih

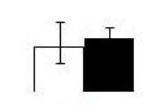

$12 \mathrm{~h}$
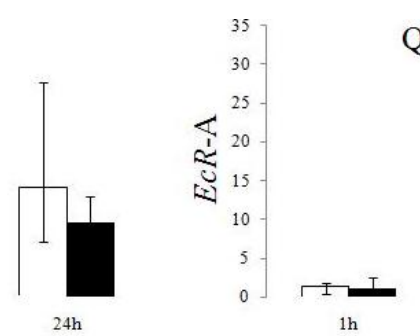

Queens/20E

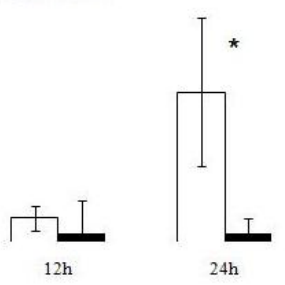

Queens/20E

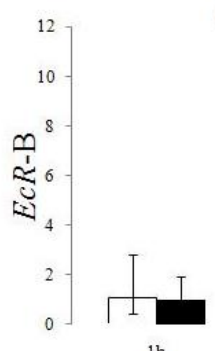

$1 \mathrm{~h}$

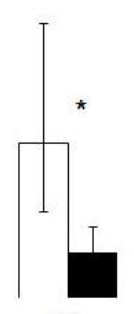

$24 \mathrm{~h}$
Workers/JH
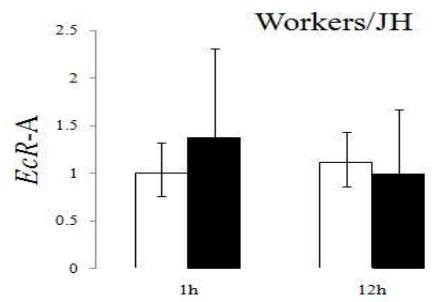

Workers/JH
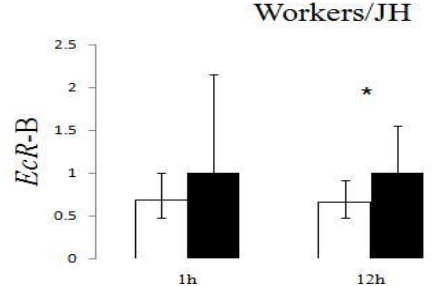
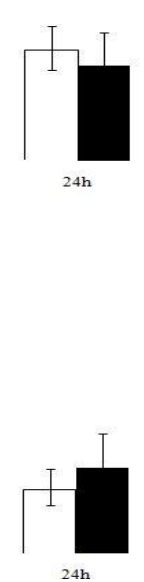

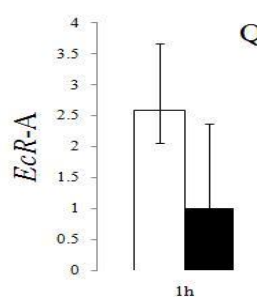

Queens/JH

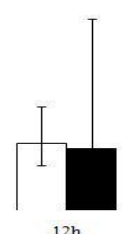

$12 \mathrm{~h}$

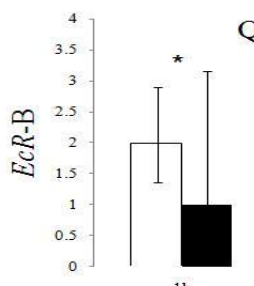

Queens/JH
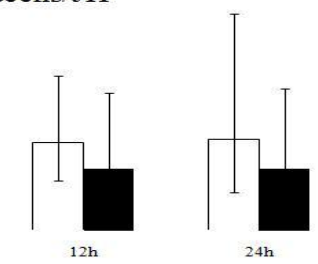

Control

20E Treatment

Figure 4. $E c R$ expression response to artificially augmented levels of morphogenetic hormones 20hydroxiedsysone (20E) and juvenile hormone ( $\mathrm{JH})$ in honeybee castes. A) Workers B) Queens. Brown-eyed, unpigmented cuticle pupae were applied $5 \mu \mathrm{g}$ of $20 \mathrm{E}$ or $10 \mu \mathrm{g}$ of $\mathrm{JH}-\mathrm{III}$ and the RNA samples from fat bodies were obtained after 1, 12, 24 and 48h. The ordinate represents densitometric units (DU) of sqPCR reactions and each value is an average of three separate experiments. SEMs are indicated by vertical bars. Statistical differences in gene expression between treated and control groups are indicated by $(*) . P<0.05$, Mann-Whitney Test. 
Table 1. Developmental stages of A. mellifera (modified from Michelette and Soares, 1993).

\begin{tabular}{cc}
\hline Abbreviation & Developmental Stage \\
\hline E & Embryo \\
L1 & first instar Larva \\
L2 & second instar Larva \\
L3 & third instar Larva \\
L4 & fourth instar Larva \\
L5F1 & fifth instar Larva, Feeding stage 1 \\
L5F2 & fifth instar Larva, Feeding stage 2 \\
L5F3 & fifth instar Larva, Feeding stage 3 \\
L5S1 & fifth instar Larva, cocoon-Spinning stage 1 \\
L5S2 & fifth instar Larva, cocoon-Spinning stage 2 \\
L5S3 & fifth instar Larva, cocoon-Spinning stage 3 \\
PP1 & fifth instar larva, Pre-Pupa 1 \\
PP2 & fifth instar larva, Pre-Pupa 2 \\
PP3 & fifth instar larva, Pre-Pupa 3 \\
Pw & white-eyed Pupa, unpigmented cuticle \\
Pp & pink-eyed Pupa, unpigmented cuticle \\
Pdp & Dark pink-eyed Pupa, unpigmented cuticle \\
Pb & brown-eyed Pupa, unpigmented cuticle \\
$\mathrm{Pbl}$ & brown-eyed Pupa, light pigmented cuticle \\
$\mathrm{Pbm}$ & brown-eyed Pupa, intermediary pigmented cuticle \\
$\mathrm{Pbd}$ & brown-eyed Pupa, dark pigmented cuticle \\
$\mathrm{NE}$ & Newly Emerged \\
&
\end{tabular}


Apis mellifera ecdysone receptor (Ecr), transcript variant $A$, mRNA, sequence 2,635 nt

Accession number NM_001098215 XM_394760

1 gtgtcgtgtt ggcagccact cccaggttag ccgccgctac ggaccaggcc acgtccgcca

61 ccatggacac cagcgactcc agcatggaca cgactaacgg ggggggctcg agcgccgggg

121 ttggcgtggt cggtgggacg atcgcctctg tggtggcagg ggccgcgtcc ttgaccctgg

181 tcaaggccga gacgcccgaa cacctggccg ggacgtcgac gacggccgcc gcgacgccga

241 cgcccccgtc ggtccccgtc ggatcggcgg tggccgggac ggccggtggc gccctcttcc

301 ccggcatgge cgcggcgggc aagggcgccg cgagatccga cgactggctc gcgaacgcga

361 acagcccggt cggctccccg tccgccgcgt tgcagccgca gcacgtggtc tacgggaatc

421 ctcagcaaca acagctcgcc gccgagacgc agcagcagca gcagcagccg cccctcgccc

481 actcaagccc cctcgcgcat cagcagcaac agcccaacag caacaacggc tacgccagtc

541 ctatgagcac cagcagctac gatccttaca gtcccaacag taagataggt agggacgagt

601 tgtcgcagcc tggctctttg aacgggtatg ggagcagcgg aggcggaggc ggcggaggag

661 gaggaggagg cggcggcggc ggcggaggcg gaggcggagg aggtggtgga ggaggaggag

721 gaggcggggg tggtggagga ggaggcagcg acgggtgcga cgcgaggaag aagaagggac

781 cgaccccgag gcagcaggag gagttgtgcc tggtctgcgg cgatcgcgcc tccggttacc

841 actacaacgc gctcacgtgc gaggggtgca aaggtttctt ccggcggagc atcactaaga

901 acgcggtcta tcagtgtaaa tacgggaaca attgcgagat cgacatgtac atgaggcgca

961 agtgtcagga gtgcaggttg aagaagtgtt tgacggtcgg gatgaggccc gagtgcgtgg

1021 tgcccgaata ccagtgcgcc gtgaagcgga aggagaagaa ggcgcaaaag gagaaggaca

1081 agccgaacag tacaacgatg aacgggtccc cgggcagcgg cggtatacgg agcgatcaga

1141 tgggggtgaa gatcgagccg gccgaggcgg agtcgttgtc cacgtccgga agcagcggga

1201 tcctgacgcc tgtcagccct tacggctacg tgaaaccgat cagccccgag caggaggaat

1261 tgatacacag gctcgtctac ttccagaacg agtacgagca accgagcgag gaggatctca

1321 agaggatcac gaatcagccc tcggagggag aggacatcag tgattacaag ttcaggcaca

1381 taaccgagat cacgatcctc acggtccaat tgatcgtcga attctcgaag agattgccag

1441 gcttcgacga gctgatgcgg gaggatcaga tcgctctgct caaggcctgc tccagcgagg

1501 tgatgatgct tcgaatggcg aggaagtacg acgtgcagac ggacagcata atattcgcca

1561 ataatcagcc ttacacgaag gacagctata ccgtggcggg tatgggcgag acgatcgagg

1621 atttgctaca tttctgccgg cagatgtacg ccatgaaggt gaacaacgcc gagtacgcgt

1681 tgttgaccgc catcgtcata ttctcagaga ggccgaacct gctcgagggc tggaaggtgg

1741 agaagattca ggagatctat ctggaggcgt tgagggcgta cgtggacaac aggcgcagac

1801 cgaatccggg cacggttttc gccagattgc tgtccgtgtt gaccgagctg cggaccctcg

1861 gcaaccagaa cagcgagatg tgcttcagcc tcaagttcaa gaacaaaaag ctgccagttt

1921 tcctcgccga gatctgggac gtgacaccct agttccccgg tggccgatcc ccgtcggctg

1981 atagtgttgt ttcatcgcga gtccgcgtcg cgcccggaac gttcaagctg aacaccgaat

2041 ggagctgcgg aacgctgcgc gccacgcgga gaacctcctg tactagtgcg ccaccaccac

2101 caccaccacc accaccatgc cactgcctgg cccgattagt agacacaggt gacgtctacc

2161 gaagaagcat cgaggaatga tcgattcgac ttcatcacac cttcttctct ccgcacttca

2221 cccggcttcg tgaagctgtg ctggaaacgg gggggggggg ggcagctttc gacagtgctt

2281 tacgaaaacg cttagaaacg ctgtggagga tacgataata atattttacg cgaagtcagg

2341 aggaaggagg aaggaggaag gaggaaaggc agtggcgagg cacccaggct gtgatacgta

2401 gagacagtac agagactgta ataaggagct acctacctac agttacgtta ttattcntat

2461 attctctacc tggctaccta cctacctacc tacctaccta cctacctacc tacctaccta

2521 cctacctacc tacctaccta cctacccccc cggaatcgat aaatgtaal gtgtaacgtg

2581 taatgttaat aaggtagcgg ctaactaaaa aaaaaaaaa aaaaaaaaa aaaa

EcR-A amino acid sequence - 620 total, 175 aa exclusives;

MDTSDSSMDTTNGGGSSAGVGVVGGTIASVVAGAASLTLVKAETPEHLAGTSTTAAATP TPPSVPVGSAVAGTAGGALFPGMAAAGKGAARSDDWLANANS PVGSPSAALQPQHVVYG NPQQQQLAAETQQQQQQPPLAHSSPLAHQQQQPNSNNGYASPMSTSSYDPYSPNSKIGR DELSQPGSLNGYGSSGGGGGGGGGGGGGGGGGGGGGGGGGGGGGGGGGGGGSDGCDARK KKGPTPRQQEELCLVCGDRASGYHYNALTCEGCKGFFRRS ITKNAVYQCKYGNNCEIDM YMRRKCQECRLKKCLTVGMRPECVVPEYQCAVKRKEKKAQKEKDKPNSTTMNGSPGSGG IRSDQMGVKIEPAEAESLSTSGSSGILTPVSPYGYVKPISPEQEELIHRLVYFQNEYEQ PSEEDLKRITNQPSEGEDISDYKFRHITEITILTVQLIVEFSKRLPGFDELMREDQIAL LKACS SEVMMLRMARKYDVQTDS I I FANNQPYTKDSYTVAGMGET IEDLLHFCRQMYAM KVNNAEYALLTAIVIFSERPNLLEGWKVEKIQEIYLEALRAYVDNRRRPNPGTVFARLL SVLTELRTLGNQNSEMCFSLKFKNKKLPVFLAEIWDVTP 


\section{Apis mellifera ecdysone receptor (Ecr), transcript variant B1, mRNA, sequence 2,782nt}

\section{Accession number, NM_001159355}

1 tatagaggaa gagggacacg aggaaaagca gcgcggccaa gcgagacgga cgatgcgtga

61 gagctcgggg accatggact cttgacagtg aatcgattct ctcgcgcgct gccctgacct 121 cgtattcctt gccgcaattt cggtcgacga acgaattatc gaggtcaacg actagcgtgg 181 tggtagtagt agtttctgtt accgtaaaca gagtgttacg ttgcactgag aggaaaggaa 241 aggaaaaatc tgaggggata atcgaaatct cgtcttttt tgaacgggac cacggttttc 301 agtgtggtcg cgcgtgcaac acagtgatat tttctttcc cccgacggaa gtgacgagga 361 aaattgggac ggtggagtcg agggaacagg gaacggtgat cctgaaggtg gagcaggctg 421 acgagatgct gcagactgtg ccccgtgtgc ctgtcgcggg gatcaagcgg cgatggggta 481 acaggcacgc aggaagtctg caggagtcga gcccagaggt ttcgagcagc ggcgtgctgt 541 cgccaccgcc gaatttccaa ccctccacgc cggagagcgc ggtcgtaaag agcgaagaac 601 tccagctgtg ggatctggac cttcatcggg gcctgcagac gaacggggat cattatcggg 661 ctaccatcac cgccacgacc accaccacag tgttgccaac ggtcaccgat cctgcctcgc 721 cattcaccac ccccatcgaa ggtagggacg agttgtcgca gcctggctct ttgaacgggt 781 atgggagcag cggaggcgga ggcggcggag gaggaggagg aggcggcggc ggcggcggcg 841 gaggcggagg aggaggagga ggaggaggag gcgggggtgg tggaggagga ggcagcgacg 901 ggtgcgacgc gaggaagaag aagggaccga ccccgaggca gcaggaggag ttgtgcctgg 961 tctgcggcga tcgcgcctcc ggttaccact acaacgcgct cacgtgcgag gggtgcaaag 1021 gtttcttccg gcggagcatc actaagaacg cggtctatca gtgtaaatac gggaacaatt 1081 gcgagatcga catgtacatg aggcgcaagt gtcaggagtg caggttgaag aagtgtttga 1141 cggtcgggat gaggcccgag tgcgtggtgc ccgaatacca gtgcgccgtg aagcggaagg 1201 agaagaaggc gcaaaaggag aaggacaagc cgaacagtac aacgatgaac gggtccccgg 1261 gcagcggcgg tatacggagc gatcagatgg gggtgaagat cgagccggcc gaggcggagt 1321 cgttgtccac gtccggaagc agcgggatcc tgacgcctgt cagcccttac ggctacgtga 1381 aaccgatcag ccccgagcag gaggaattga tacacaggct cgtctacttc cagaacgagt 1441 acgagcaacc gagcgaggag gatctcaaga ggatcacgaa tcagccctcg gagggagagg 1501 acatcagtga ttacaagttc aggcacataa ccgagatcac gatcctcacg gtccaattga 1561 tcgtcgaatt ctcgaagaga ttgccaggct tcgacgagct gatgcgggag gatcagatcg 1621 ctctgctcaa ggcctgctcc agcgaggtga tgatgcttcg aatggcgagg aagtacgacg 1681 tgcagacgga cagcataata ttcgccaata atcagcctta cacgaaggac agctataccg 1741 tggcgggtat gggcgagacg atcgaggatt tgctacattt ctgccggcag atgtacgcca 1801 tgaaggtgaa caacgccgag tacgcgttgt tgaccgccat cgtcatattc tcagagaggc 1861 cgaacctgct cgagggctgg aaggtggaga agattcagga gatctatctg gaggcgttga 1921 gggcgtacgt ggacaacagg cgcagaccga atccgggcac ggttttcgcc agattgctgt 1981 ccgtgttgac cgagctgcgg accctcggca accagaacag cgagatgtgc ttcagcctca 2041 agttcaagaa caaaagctg ccagttttcc tcgccgagat ctgggacgtg acaccctagt 2101 tccccggtgg ccgatccccg tcggctgata gtgttgtttc atcgcgagtc cgcgtcgcgc 2161 ccggaacgtt caagctgaac accgaatgga gctgcggaac gctgcgcgcc acgcggagaa 2221 cctcctgtac tagtgcgcca ccaccaccac caccaccacc accatgccac tgcctggccc 2281 gattagtaga cacaggtgac gtctaccgaa gaagcatcga ggaatgatcg attcgacttc 2341 atcacacctt cttctctccg cacttcaccc ggcttcgtga agctgtgctg gaaacggggg 2401 gggggggggc agctttcgac agtgctttac gaaaacgctt agaaacgctg tggaggatac 2461 gataataata ttttacgcga agtcaggagg aaggaggaag gaggaaggag gaaaggcagt 2521 ggcgaggcac ccaggctgtg atacgtagag acagtacaga gactgtaata aggagctacc 2581 tacctacagt tacgttatta ttcntatatt ctctacctgg ctacctacct acctacctac 2641 ctacctacct acctacctac ctacctacct acctacctac ctacctacct acccccccgg 2701 aatcgataaa tgtaaatgtg taacgtgtaa tgttaataag gtagcggcta actaaaaaa 2761 aaaaaaaaa aaaaaaaaa AA

EcR-B amino acid sequence - 557 total, 105 aminno acids excluives;

MLQTVPRVPVAGIKRRWGNRHAGSLQESSPEVSSSGVLSPPPNFQPSTPESAVVKSEELQLWDLDLHR GLQTNGDHYRATITATTTTTVLPTVTDPASPFTTPIEGRDELSQPGSLNGYGSSGGGGGGGGGGGGGG GGGGGGGGGGGGGGGGGGGGSDGCDARKKKGPTPRQQEELCLVCGDRASGYHYNALTCEGCKGFFRRS ITKNAVYQCKYGNNCEIDMYMRRKCQECRLKKCLTVGMRPECVVPEYQCAVKRKEKKAQKEKDKPNST TMNGSPGSGGIRSDQMGVKIEPAEAESLSTSGSSGILTPVSPYGYVKPISPEQEEL IHRLVYFQNEYE QPSEEDLKRITNQPSEGEDISDYKFRHITEITILTVQLIVEFSKRLPGFDELMREDQIALLKACSSEV MMLRMARKYDVQTDS I I FANNQPYTKDSYTVAGMGET IEDLLHFCRQMYAMKVNNAEYALLTAIVIFS ERPNLLEGWKVEKIQEIYLEALRAYVDNRRRPNPGTVFARLLSVLTELRTLGNQNSEMCFSLKFKNKK LPVFLAEIWDVTP 
CLUSTAL 2.1 multiple sequence alignment - shared aminoacids

ECR-B

ECR-A

ECR-B

ECR-A

$\mathrm{ECR}-\mathrm{B}$

ECR-A

ECR-B

ECR-A

ECR-B

ECR-A

ECR-B

ECR-A

ECR-B

ECR-A

ECR-B

ECR-A
GRDELSQPGSLNGYGSSGGGGGGGGGGGGGGGGGGGGGGGGGGGGGGGGGG - - SDGCDAR GRDELSQPGSLNGYGSSGGGGGGGGGGGGGGGGGGGGGGGGGGGGGGGGGGGGSDGCDAR

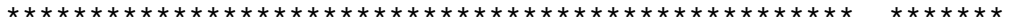

KKKGPTPRQQEELCLVCGDRASGYHYNALTCEGCKGFFRRS ITKNAVYQCKYGNNCEIDM KKKGPTPRQQEELCLVCGDRASGYHYNALTCEGCKGFFRRS ITKNAVYQCKYGNNCEIDM

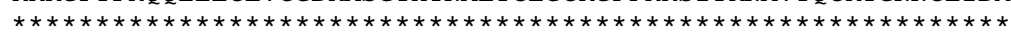

YMRRKCQECRLKKCLTVGMRPECVVPEYQCAVKRKEKKAQKEKDKPNSTTMNGSPGSGGI YMRRKCQECRLKKCLTVGMRPECVVPEYQCAVKRKEKKAQKEKDKPNSTTMNGSPGSGGI

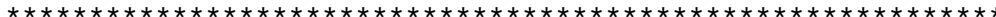

RSDQMGVKIEPAEAESLSTSGSSGILTPVSPYGYVKPISPEQEELIHRLVYFQNEYEQPS RSDQMGVKIEPAEAESLSTSGSSGILTPVSPYGYVKPISPEQEELIHRLVYFQNEYEQPS

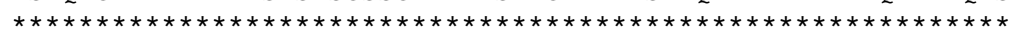

EEDLKRITNQPSEGEDISDYKFRHITEITILTVQLIVEFSKRLPGFDELMREDQIALLKA EEDLKRITNQPSEGEDISDYKFRHITEITILTVQLIVEFSKRLPGFDELMREDQIALLKA $* * * * * * * * * * * * * * * * * * * * * * * * * * * * * * * * * * * * * * * * * * * * * * * * * * * * * * * * * * * *$

CSSEVMMLRMARKYDVQTDS I IFANNQPYTKDSYTVAGMGETIEDLLHFCRQMYAMKVNN CSSEVMMLRMARKYDVQTDS I I FANNQPYTKDSYTVAGMGET IEDLLHFCRQMYAMKVNN

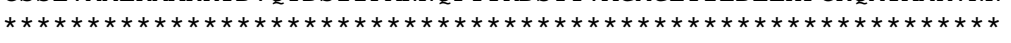

AEYALLTAIVIFSERPNLLEGWKVEKIQEIYLEALRAYVDNRRRPNPGTVFARLLSVLTE AEYALLTAIVIFSERPNLLEGWKVEKIQEIYLEALRAYVDNRRRPNPGTVFARLLSVLTE

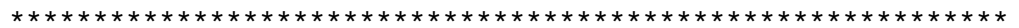

LRTLGNQNSEMCFSLKFKNKKLPVFLAEIWDVTP LRTLGNQNSEMCFSLKFKNKKLPVFLAEIWDVTP $\star * * * * * * * * * * * * * * * * * * * * * * * * * * * * * * * * *$ 